\title{
Mesozoic history of the southeastern Tibetan plateau: Sediment provenance, paleoclimate, and surface elevation history
}

Fei Shang

Follow this and additional works at: https://researchrepository.wvu.edu/etd

\section{Recommended Citation}

Shang, Fei, "Mesozoic history of the southeastern Tibetan plateau: Sediment provenance, paleoclimate, and surface elevation history" (2016). Graduate Theses, Dissertations, and Problem Reports. 6615.

https://researchrepository.wvu.edu/etd/6615

This Dissertation is protected by copyright and/or related rights. It has been brought to you by the The Research Repository @ WVU with permission from the rights-holder(s). You are free to use this Dissertation in any way that is permitted by the copyright and related rights legislation that applies to your use. For other uses you must obtain permission from the rights-holder(s) directly, unless additional rights are indicated by a Creative Commons license in the record and/ or on the work itself. This Dissertation has been accepted for inclusion in WVU Graduate Theses, Dissertations, and Problem Reports collection by an authorized administrator of The Research Repository @ WVU.

For more information, please contact researchrepository@mail.wvu.edu. 


\title{
MESOZOIC HISTORY OF THE SOUTHEASTERN TIBETAN PLATEAU: SEDIMENT PROVENANCE, PALEOCLIMATE, AND SURFACE ELEVATION HISTORY
}

\author{
Fei Shang \\ Dissertation submitted \\ to the Eberly College of Arts and Sciences at West \\ Virginia University \\ in partial fulfillment of the requirements for the degree of \\ Doctor of Philosophy in \\ Geology
}

\author{
Amy L. Weislogel, Ph.D., Chair \\ Shikha Sharma, Ph.D. \\ Jaime Toro, Ph.D. \\ Kathleen C. Benison, Ph.D. \\ Delores M. Robinson, Ph.D. \\ Department of Geology and Geography
}

Morgantown, West Virginia

2016

Keywords: Southeastern Tibet; Qamdo Basin; Sediment Provenance;

Paleoclimate; mid-Cretaceous Climate Sensitivity; Paleoaltimetry

Copyright 2016 Fei Shang 


\title{
ABSTRACT \\ Mesozoic History of the Southeastern Tibetan Plateau: Sediment Provenance, Paleoclimate, and Surface Elevation History
}

\author{
Fei Shang
}

The region of southeastern Tibetan Plateau is one of the most geologically complicated areas on earth. Numerous continental fragments, volcanic arcs, and oceanic crust were swept together as a collage from Paleozoic to Recent to form the basic tectonic framework of the region. The history of fragmentation, accretion, and deformation is controlled by tectonic activities of several plate boundaries that have been activated and reactivated at numerous times. The multi-phase tectonic history of eastern Tibetan Plateau makes tectonic history reconstruction very difficult due to the tectonic overprints of younger tectonisms (i.e., Cenozoic Indo-Asia collision and Indochina lateral extrusion). The lack of geological knowledge about the pre-Cenozoic southeastern Tibetan Plateau (e.g., precollisional upper crustal configuration and initial age of thickening of Tibetan crust) hinders the development of a comprehensive mechanical model that can account for the rise of the vast plateau.

This dissertation presents new results of a multi-disciplinary investigation of the linkages between erosion, uplift and regional climate change associated with the Mesozoic accretionary tectonism in southeastern Tibet. We studied sedimentary record preserved in a robust and strategically-located geologic archive -the Qamdo basin system. Since tectonics can greatly influence the geomorphic and stratigraphic development of sedimentary basins, studying evolution of the Qamdo basin could provide useful insights into the tectonic information of the adjacent areas.

The following questions are addressed in the three chapters of this thesis:

- What are the sediment sources for the Mesozoic Qamdo basin?

- Is there a link between provenance of Qamdo sediments and Mesozoic accretionary tectonism of southeastern Tibet, such as the closure of the Paleo-Tethyan and Meso-Tethyan oceans?

- What impact did Cretaceous global climate change have on local climate of southeastern Tibet?

- What impact did Cretaceous orogenesis have on local climate of southeastern Tibet?

- Can we estimate the amount of Cretaceous surface uplift in southeastern Tibet by distinguishing between effects caused by global climate and local orogenesis?

This dissertation contains three separate chapters focus on sediment provenance of the Qamdo basin, Cretaceous paleoclimate and paleoaltimetry of southeastern Tibet.

Chapter 1 provides an overview of the sedimentology, stratigraphic characterization and sandstone provenance of the Mesozoic Qamdo basin. Study revealed that the Qamdo basin was sourced primarily from erosion of Triassic turbidite of the Yidun Group, metasedimentary rocks of the Zhongza massif, igneous rocks of the Jomda-Weixi arc and 
Bangong arc, and recycled Upper Triassic Qamdo strata. Upper Triassic sediments of the Qamdo basin were sourced primarily from the inverted Yidun Group as a result of the closure of the Paleo-Tethyan Ganzi-Litang ocean and development of a widespread foldthrust belt in northeastern Tibet during Late Triassic time. Three distinct depocenters developed in the Qamdo basin by the beginning of Early Jurassic time, as indicated by a spatial diversification of detrital zircon age signatures. The northern depocenter received detritus derived primarily from the recycled Upper Triassic Qamdo strata; whereas, the central depocenter has a mixed provenance of Zhongza massif metasedimentary rocks and recycled Upper Triassic Qamdo strata. The prominent 230-245 Ma peak in the southern depocenter signifies sediment influx from the Jomda-Weixi arc. A lack of Jurassic age zircons in the Lower Jurassic sedimentary rocks is interpreted to reflect a temporal geographical segregation between the Bangong arc and the Qamdo basin due to the opening of a short-lived Early Jurassic oceanic backarc basin, which was probably related to slab rollback during Meso-Tethys subduction. The Middle-Upper Jurassic strata were sourced from recycled Upper Triassic Qamdo strata and exhumed Bangong arc plutons that intruded the Tongka basement. Abundant 165-190 Ma zircon grains in the MiddleUpper Jurassic strata suggest exhumation and erosion of the Bangong arc related to the convergence between Lhasa and Qiangtang blocks during Mid-Late Jurassic time.

Cretaceous strata were mostly sourced from the Jomda-Weixi arc combined with sediment input from internally-recycled Qamdo strata. The cause of the reactivated exhumation of the Jomda-Weix arc was probably related to the northward underthrusting of the Lhasa terrane beneath the Qiangtang block during Early Cretaceous time. This chapter was submitted to GSA bulletin and is currently in review.

Chapter 2 employs carbonate clumped-isotope thermometry in combination with paleosol $\mathrm{CO}_{2}$ barometry to reconstruct mid-Cretaceous terrestrial climate conditions of southeastern Tibet. The mid-Cretaceous (Cenomanian-Turonian) "super-greenhouse" world of $\sim 100$ million years ago was characterized by high levels of atmospheric $\mathrm{CO}_{2}$ driven by intense volcanic activity, and characterized by high sea surface temperatures (SSTs) and a small equator-to-pole temperature gradient. Although it is commonly accepted that the extreme warmth of the mid-Cretaceous was driven by increased atmospheric $p \mathrm{CO}_{2}$, large discrepancies exist between climate models and proxy data, as models often fail to simulate SSTs unless atmospheric $p \mathrm{CO}_{2}$ reaches implausibly high levels (> 3,500 ppm) when using a standard range of model climate sensitivities. We reconciled this discrepancy using new temperature and $p \mathrm{CO}_{2}$ reconstructions that indicate climate sensitivity may have been underestimated for greenhouse conditions. We use carbonate clumped isotope thermometry to constrain soil temperatures, meteoric water $\delta_{18} \mathrm{O}$ ratios, and $p \mathrm{CO}_{2}$ levels for the Cenomanian-Turonian interval ( $\left.\sim 101-90 \mathrm{Ma}\right)$ from paleosol carbonates in southeastern Tibet, which was located at $\sim 15^{\circ} \mathrm{N}$ during this time. Minimum summer temperatures were $\sim 30^{\circ} \mathrm{C}$ during the Cenomanian, with a warming of $\sim 10^{\circ} \mathrm{C}$ associated with major increases in $\mathrm{pCO}_{2}$ and soil water $\delta_{18} \mathrm{O}$ values during the Cenomanian-Turonian transition. The reconstructed terrestrial temperature trends mirror coeval tropical SST proxies. Our most conservative estimate of climate sensitivity during the Cenomanian-Turonian interval yields a value of $\sim 10^{\circ} \mathrm{C}$ per $\mathrm{CO}_{2}$ doubling under high $\mathrm{CO}_{2}$ "super-greenhouse" conditions, significantly higher than modern day values of $\sim 1.5$ $4.5^{\circ} \mathrm{C}$ suggested by the Intergovernmental Panel on Climate Change (IPCC). This chapter is under review by coauthors and will be submitted to Earth and Planetary Science Letters.

Chapter 3 reports results from clumped isotope, strontium isotope and sedimentological analyses of the entire succession of Late Cretaceous (CenomanianSantonian) strata preserved in the Qamdo basin, accompanied by results of Late 
Cretaceous climate modeling. This chapter provides evidence of an episode of surface uplift in southeastern Tibet during Late Cretaceous (Coniacian-Santonian) time. We examined two stratigraphic sections in the Cenomanian-Santonian strata of the Qamdo basin and find that petrography, burial history and elemental composition of paleosol carbonates are consistent with preservation of original isotopic signatures and minimal influence from solid-state reordering. Average soil temperatures (i.e., $\Delta_{47}-\mathrm{T}$ ) decreased from $44 \pm 1.5^{\circ} \mathrm{C}(95 \% \mathrm{Cl})$ in the Turonian to $38 \pm 3.5^{\circ} \mathrm{C}(95 \% \mathrm{Cl})$ by the Santonian time, coincident with decrease of average $\delta^{18} \mathrm{O}_{\text {water }}$ values from $-6.3 \pm 0.5 \%$ o $(95 \% \mathrm{Cl})$ to $-7.3 \pm$ $0.5 \%$ ( $95 \% \mathrm{Cl})$. Climate model outputs and tropical sea surface temperature (SST) records both show that global climate during the Turonian-Santonian interval were relatively warm and stable, without evidence of significant global cooling. Together, the observed changes in $\Delta_{47}-\mathrm{T}$ and $\delta^{18} \mathrm{O}_{\text {water }}$ values exhibit a pattern that is consistent with surface elevation changes during Late Cretaceous time. Assuming temperature and isotopic lapse rates of $\sim 6{ }^{\circ} \mathrm{C} / \mathrm{km}$ and $\sim 1 \% / \mathrm{km}$, respectively, under the extreme warm Late Cretaceous climate conditions, the observed $\Delta_{47}-\mathrm{T}$ and $\delta^{18} \mathrm{O}_{\text {water }}$ shifts correspond to a positive elevation change of $\sim 1 \mathrm{~km}$ in southeastern Tibet during Late Cretaceous time. This inference is supported by evidence of strontium isotope ratios, structure, and sedimentology. Strontium isotope ratios of pedogenic carbonate increase up-section from 0.7106 to 0.7112 , indicating enhanced weathering of continental source areas. Meanwhile, the development of growth strata and occurrence of thick-bedded conglomerate layers within the Late Cretaceous strata all implying active tectonics during deposition. Together, out data suggest that a moderate topography with elevation $>1.5 \mathrm{~km}$ was probably established by Late Cretaceous time in SE Tibet. This chapter is under review by coauthors and will be submitted to Earth and Planetary Science Letters shortly. 


\section{ACKNOWLEDGEMENTS}

The completion of this dissertation could not have been possible without the help and support of many organizations, friends and colleagues. The National Science Foundation (under grants: EAR-1119219 to Weislogel and EAR-1119266 to Robinson) and West Virginia University Shared Research Facilities provided great support for this research. I would like to thank Arizona Laserchron Center personnel for assistance with laser ablation-inductively coupled plasma-mass spectrometry (LA-ICP-MS) analyses, as well as financial support provided by the National Science Foundation under grant EAR-1032156 for students travel to the Arizona LaserChron Center. I would also like to thank Antra Priyadarshi, Atreyee Bhattarcharya, and the Tripati Clumped Isotope Lab for their assistance in clumped isotope analysis. Dr. Xiumian Hu and Gaoyuan Sun from the Nanjing University and Dr. Chunmiao Zheng from Peking University helped us with field work and logistics and I would like to express my gratitude to them.

I want to express my deepest gratitude to my advisor, Dr. Amy L. Weislogel for leading me into the world of sedimentary geology and supporting me to conduct research in probably one the most wonderful places in the World for geologists - southeastern Tibet.

Special thanks to the members of my dissertation committee, including Dr. Shikha Sharma, Dr. Jaime Toro, Dr. Kathleen C. Benison at West Virginia University and Dr. Delores M. Robinson at University of Alabama. I would also like to thank Dr. Shikha Sharma and Dr. Aradhna K. Tripati at West Virginia University and University of California, Los Angeles, respectively for introducing me into the world of stable isotope geochemistry. Last and most importantly I would like to thank my mom and dad for their constant supported. A special thanks to my wife, Ruiqian Chen for her countless support.

Fei Shang 


\section{TABLE OF CONTENTS}

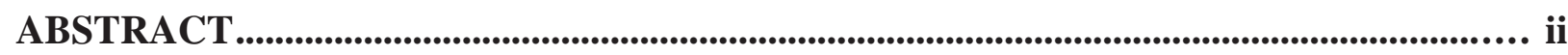

ACKNOWLEDGEMENTS ……............................................................................................. v

TABLE OF CONTENTS ....................................................................................................... vi

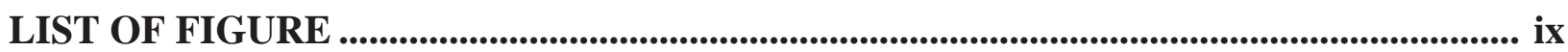

LIST OF TABLE .......................................................................................................................... xii

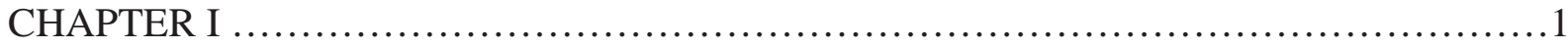

DETRITAL ZIRCON GEOCHRONOLOGY FROM THE MESOZOIC QAMDO (CHANGDU) BASIN SOUTHEASTERN TIBET: IMPLICATIONS FOR THE PALEO- AND

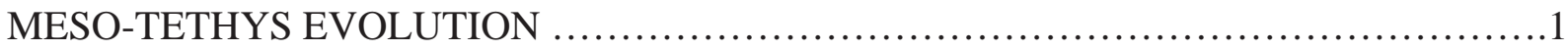

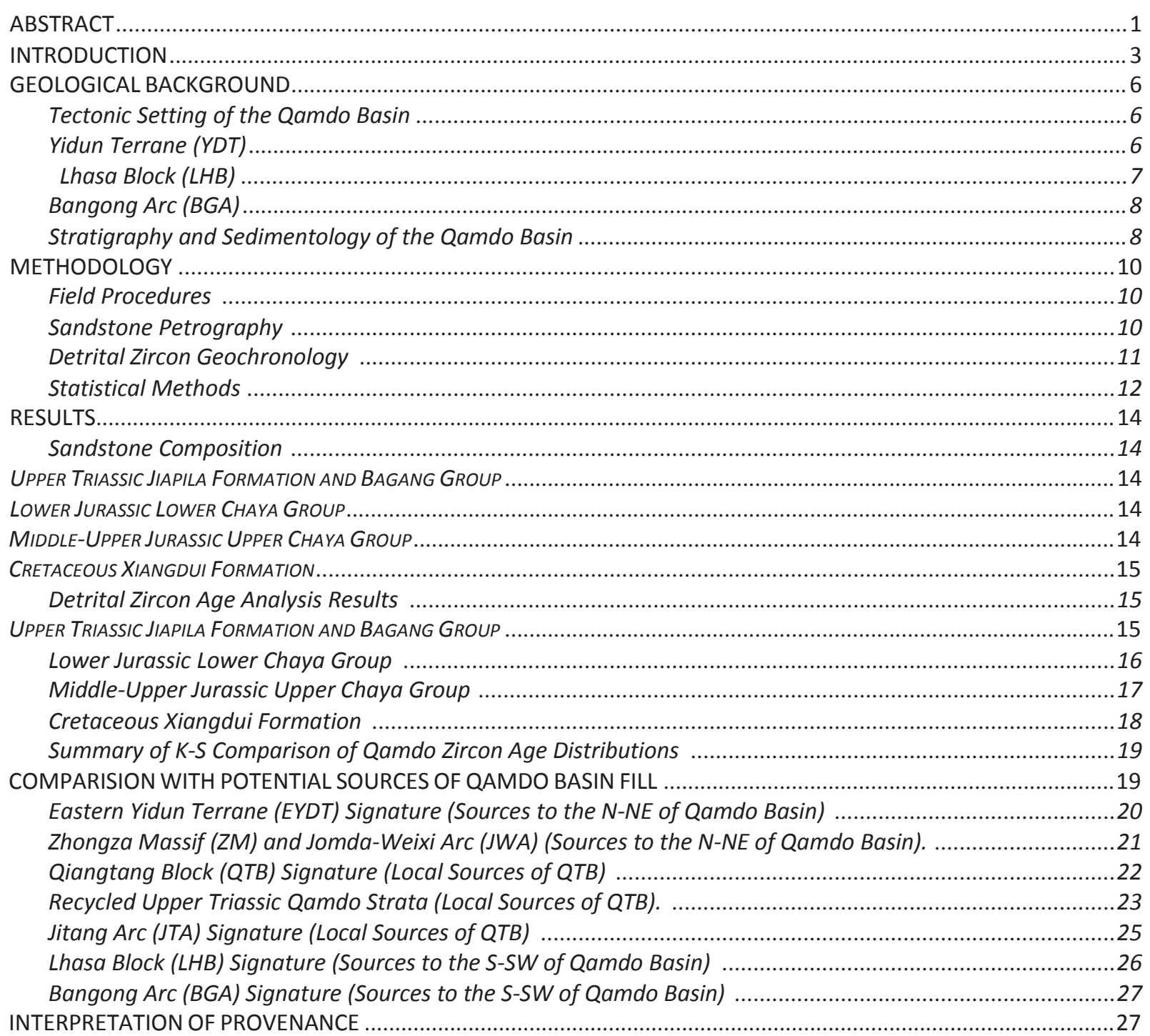

Provenance of the Upper Triassic Strata: Late Triassic Folding and Erosional Exhumation of the Yidun Terrane

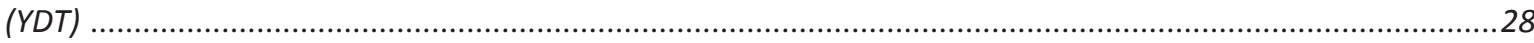

Provenance of the Lower Jurassic Strata: Localized Exhumation along the Jinsha Suture and Development of Three Separate Depocenters 
Provenance of the Middle-Upper Jurassic Strata: Exhumation of the BGA and Internally-recycled Sources ....31 Provenance of the Cretaceous Xiangdui Formation: Reactivation of Exhumation of the JWA and Internally-

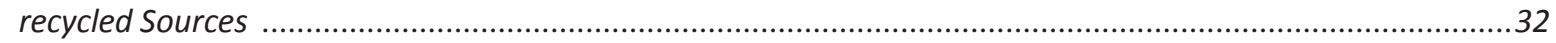

TECTONIC CONTROL ON QAMDO BASIN MESOZOIC PROVENANCE EVOLUTION ...............................................33

Late Triassic Closure of the Eastern Paleo-Tethys .........................................................................................

Early Jurassic collisional tectonism of Eastern Paleo-Tethyan closure and Middle-Late Jurassic Closure of the

Eastern Meso-Tethys ..............................................................................................................................34

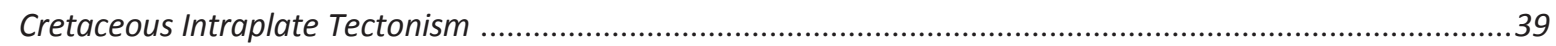

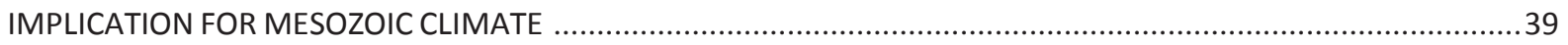

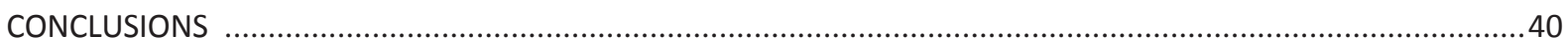

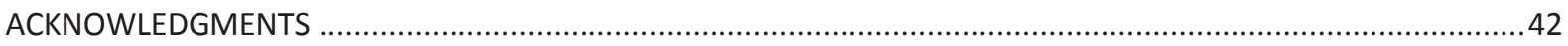

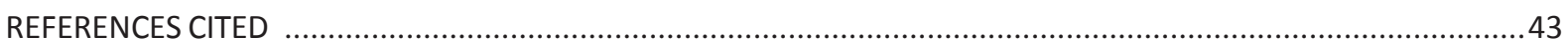

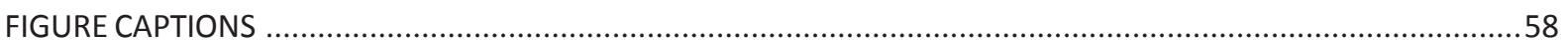

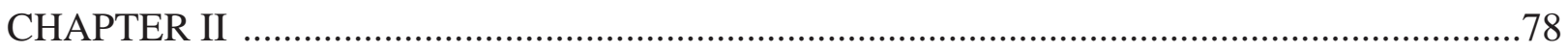

PALEOSOL RECORDS OF TROPICAL TERRESTRIAL TEMPERATURES AND ATMOSPHERIC $\mathrm{PCO}_{2}$ LEVELS DURING THE MID-CRETACEOUS (CENOMANIANTURONIAN) ‘SUPER-GREENHOUSE’ WORLD ................................................................78

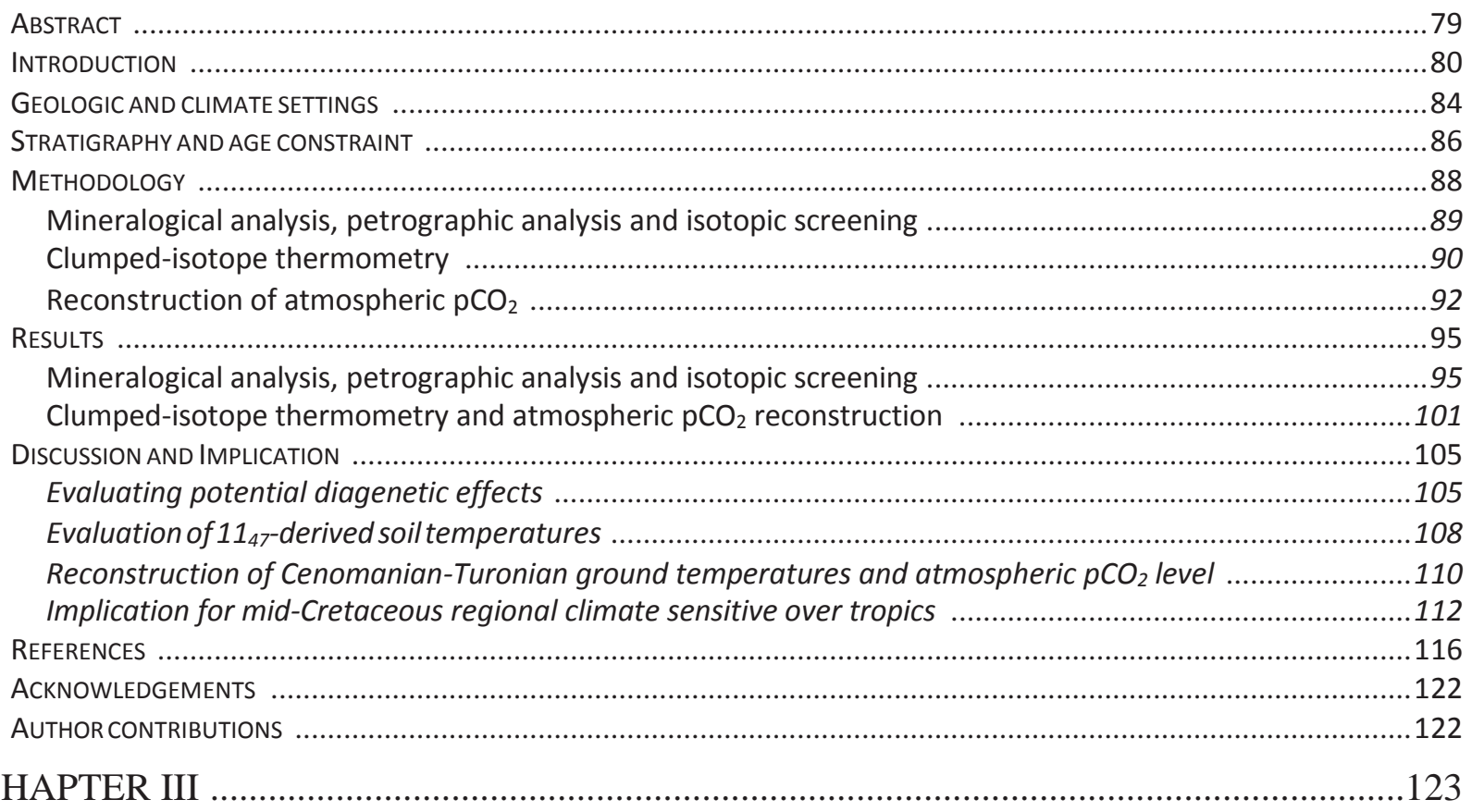

THROUGH CLUMPED ISOTOPE THERMOMETRY: IMPLICATIONS FOR LATE CRETACEOUS ELEVATION HISTORY OF SOUTHEASTERN TIBET

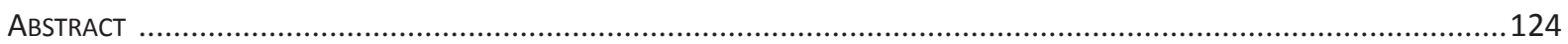

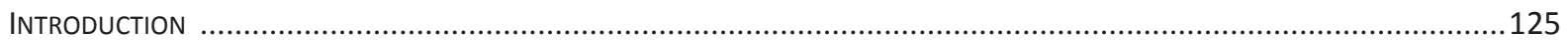

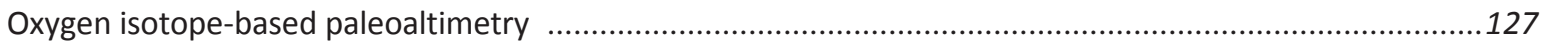

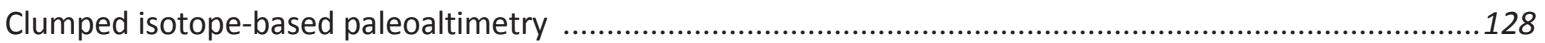

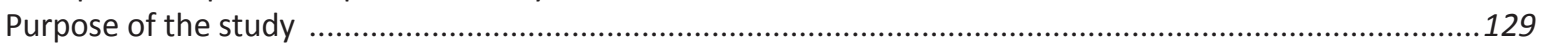

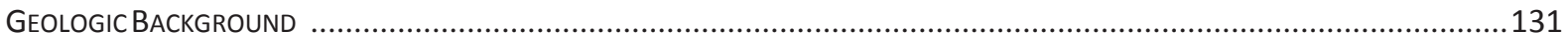


Existing Late Cretaceous (Cenomanian-Turonian) soil temperature record ..............................................133

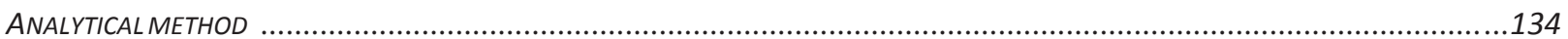

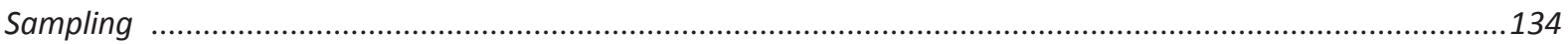

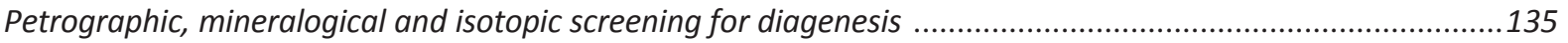

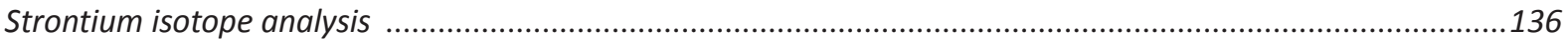

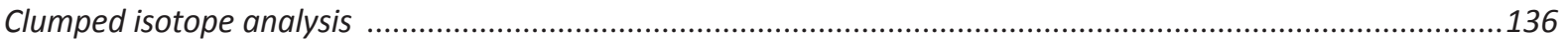

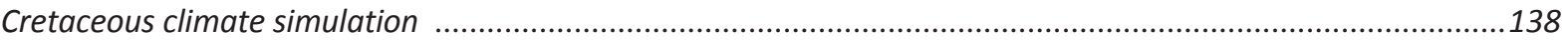

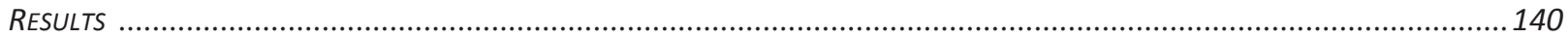

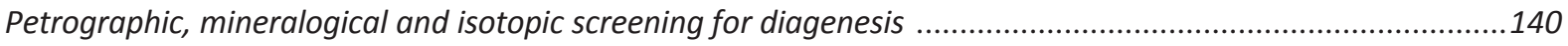

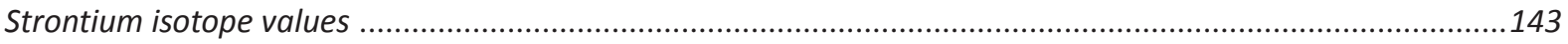

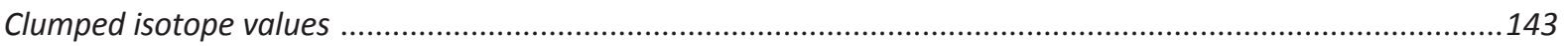

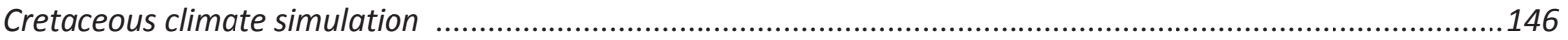

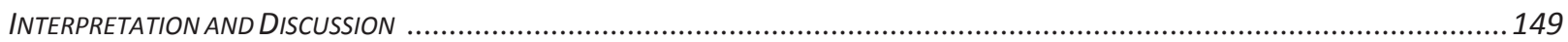

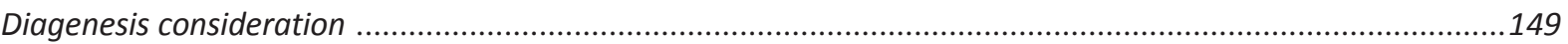

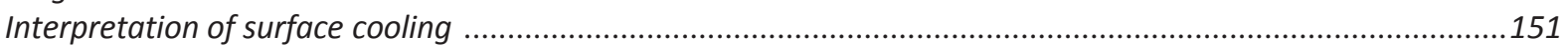

Estimation of Late Cretaceous paleo-elevation change for SE Tibet .............................................................159

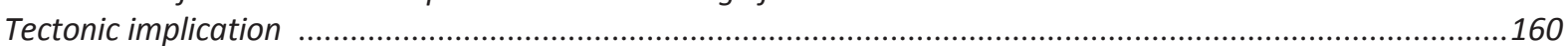

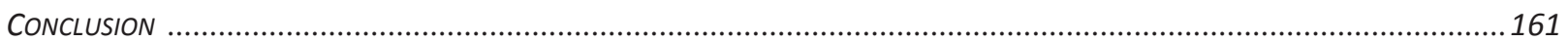

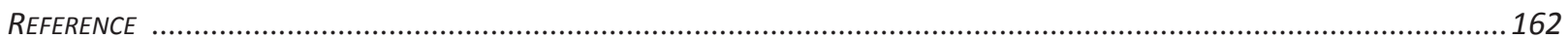


CHAPTER I

\section{LIST OF FIGURE}

FigURE 1. (A) SKETCH TECTONIC MAP OF TIBET, WESTERN CHINA SHOWING LOCATION OF THE QAMDO BASIN. BLACK BOX DELINEATES EXTENT OF THE STUDY AREA AND ADJACENT GEOLOGICAL UNITS IN SOUTHEASTERN TIBET (AFTer MENG AND ZHANG, 2000; C.G.S., 2004; WEISLOGEL ET AL., 2010). GENERAL LOCALITIES OF REFERENCE DETRITAL ZIRCON SAMPLES FROM THE QIANGTANG AND LHASA BLOCKS ARE SHOWN IN DASHED AREAS. (B) SIMPLIFIED GEOLOGICAL MAP OF QAMDO REGION SHOWING MAJOR TECTONIC UNITS AND DISTRIBUTION OF MESOZOIC ROCKS OF THE QAMDO BASIN (ADAPTED FROM PAN ET AL., 2004). LOCATIONS OF REFERENCE DETRITAL ZIRCON SAMPLES (MARKED BY WHITE NUMBER IN BLACK CYCLE): 1 - 13UTSG-1; 2 - 13UTSG-2; 3 13UTSG-427. LOCATIONS OF REFERENCE MAGMATIC ARC ZIRCON SAMPLES (MARKED BY BLACK NUMBER IN TRIANGLE): 1 - CRETACEOUS PLUTON OF THE EASTERN YIDUN TERRANE; 2 - BANGONG ARC; 3 - TRIASSIC PLUTONS OF THE EASTERN YIDUN TERRANE; 4 - JOMDA-WEIXI ARC...

FIGURE 2. GENERALIZED STRATIGRAPHIC COLUMN FOR THE QAMDO BASIN, MODIFIED FROM DU ET AL. (1997), WITH STRATIGRAPHIC LOCATION OF DETRITAL ZIRCON SAMPLES, TIMING OF REGIONAL TECTONIC EVENTS (FROM KAPP ET AL., 2005; 2007; ROGER ET AL., 2008), PALEO-FLOW DIRECTIONS, AND INTERPRETATION OF DEPOSITIONAL ENVIRONMENTS. TIME SCALE IS FROM GRADSTEIN ET AL. (2004). WHERE MULTIPLE DETRITAL ZIRCON SAMPLES OF A FORMATION HAVE BEEN ANALYZED, THE TOTAL NUMBER IS IN PARENTHESES.

FiguRE 3. DETRITAL MODES OF UPPER TRIASSIC-CRETACEOUS SANDSTONE SAMPLES FROM THE QAMDO BASIN. DATA ARE LISTED IN TABLE DR1. PROVENANCE FIELDS OF QTFL AND QMFLT TERNARY PLOTS ARE AFTER DICKINSON (1985). ADAPTED FROM XING ET AL. (2013). QTFL - TOTAL QUARTZ-FELDSPAR-LITHIC FRAGMENT; QMFLT MONOCRYSTALLINE QUARTZ-FELDSPAR-TOTAL LITHIC FRAGMENT.

FIGURE 4. PHOTOMICROGRAPHS OF THE SANDSTONE THIN SECTION SAMPLES FROM THE QAMDO BASIN. (A) UPPER TRIASSIC SANDSTONE CHARACTERIZED BY HIGH MONOCRYSTALLINE QUARTZ CONTENT WITH FEW SEDIMENTARY LITHIC FRAGMENTS (SAMPLE UT-3). (B) LOWER CHAYA SANDSTONE WITH HIGH POLYCRYSTALLINE QUARTZ ABUNDANCE (SAMPLE LJ-2). (C) SEDIMENTARY LITHIC GRAINS IN THE LOWER CHAYA SANDSTONE (SAMPLE LJ-2). (D) SEDIMENTARY LITHIC GRAINS IN THE MIDDLE-UPPER JURASSIC STRATA. (E) UPPER CHAYA SAMPLE (MUJ-5) SHOWS HIGH QUARTZ CONTENT WITH FEW VOLCANIC AND SEDIMENTARY LITHIC GRAINS. (F) VOLCANIC LITHIC GRAINS FOUND IN THE CRETACEOUS SANDSTONE SHOW VITRICLASTIC TEXTURES (SAMPLE LK-2). ALL PHOTOMICROGRAPHS WERE TAKEN WITH CROSS-POLARIZED LIGHT. QMMONOCRYSTALLINE QUARTZ; QP—POLYCRYSTALLINE QUARTZ; P-PLAGIOCLASE; LSM—SEDIMENTARY AND METASEDIMENTARY LITHIC FRAGMENTS; LVM—VOLCANIC AND METAVOLCANIC LITHIC FRAGMENTS.

FIGURE 5. HISTOGRAMS AND ZIRCON AGE PLOTS OF POTENTIAL SOURCE AREA ZIRCON DATA (BLACK SOLID LINE PROBABILITY DENSITY PLOT; BLACK DASH LINE — KERNEL DENSITY PLOT). WHITE NUMBER IN BLACK CIRCLE REPRESENTS SAMPLE LOCATIONS OF REFERENCE DETRITAL ZIRCON SAMPLES FROM THE YIDUN GROUP SHOWN ON FIGURE 1B.

FIGURE 6. DETRITAL ZIRCON AGE DISTRIBUTION PROBABILITY DENSITY PLOTS (BLACK SOLID LINE), KERNEL DENSITY PLOTS (BLACK DASH LINE) AND HISTOGRAMS FOR (A) UPPER TRIASSIC SAMPLES AND (B) LOWER CHAYA SAMPLES FROM THE QAMDO BASIN. SAMPLE LOCATIONS ARE SHOWN ON FIGURE 1B.

FIGURE 7. DETRITAL ZIRCON AGE DISTRIBUTION PROBABILITY DENSITY PLOTS (BLACK SOLID LINE), KERNEL DENSITY PLOTS (BLACK DASH LINE) AND HISTOGRAMS FOR (A) UPPER CHAYA SAMPLES AND (B) CRETACEOUS XIANGDUI SAMPLES FROM THE QAMDO BASIN. SAMPLE LOCATIONS ARE SHOWN ON FIGURE 1B... 66

FIGURE 8. HISTOGRAMS, PROBABILITY DENSITY PLOTS (BLACK SOLID LINE) AND KERNEL DENSITY PLOTS (BLACK DASH LINE) OF (A) POTENTIAL ARC SOURCES; (B) ZIRCON GRAINS <252 MA FROM THE QAMDO BASIN. GRAY BARS REPRESENT PROMINENT ARC-SIGNATURES OBSERVED IN DETRITAL RECORD. SAMPLE LOCATIONS ARE SHOWN ON FIGURE 1B.

FIGURE 9. PROBABILITY DENSITY PLOTS (BLACK SOLID LINE) AND KERNEL DENSITY PLOTS (BLACK DASH LINE) OF ZIRCON AGES OF THE ZHONGZA MSSIF AND THE ZIRCON AGES > 252 MA FROM THE QAMDO BASIN. GRAY BARS REPRESENT COMMONLY OBSERVED AGE GROUPS IN THE QAMDO BASIN.

FIGURE 10. A GENERALIZED DEPOSITIONAL MODEL FOR EVOLUTION OF THE QAMDO BASIN, SHOWING SEPARATE DEPOCENTERS AND ASSOCIATED DRAINAGES TAPPING DIFFERENT SOURCE AREAS. (A) LATE TRIASSIC (CA.220200 MA) QAMDO BASIN WAS PRIMARILY SOURCED FROM SYNOROGENIC DETRITUS DERIVED FROM FOLDING AND 
EXHUMATION OF THE YIDUN TERRANE. (B) EARLY JURASSIC (CA.200-175 MA), THREE DISTINCT DEPOCENTERS WERE DEVELOPED IN THE BASIN DUE TO BASIN CONTRACTION AND LOCALIZED UPLIFT ALONG THE JINSHA SUTURE. THE BASIN WAS SOURCED BY THE ZHONGZA MASSIF, THE JOMDA-WEIXI ARC, AND RECYCLED UPPER TRIASSIC QAMDO STRATA. A SHORT-LIVED BACKARC BASIN TO THE WEST OF THE QAMDO BASIN PREVENTED THE BANGONG ARC FROM SOURCING THE BASIN. (C) MidDlE TO LATE JURASSIC (CA.175-145 MA), ABUNDANT BANGONG ARC-DERIVED SEDIMENTS STARTED TO REACH THE BASIN AS A RESULT OF COLLISION BETWEEN THE QIANGTANG AND LHASA BLOCKS, CAUSING UPLIFT AND EXHUMATION OF THE ARC. THE BASIN WAS SOURCED FROM BOTH THE BANGONG ARC AND INTERNALLY RECYCLED SOURCES. (D) CRETACEOUS (CA.145-65 MA), THE BASIN SHRUNK SIGNIFICANTLY TOWARD THE SOUTH AND SEDIMENTS WERE DERIVED FROM THE JOMDA-WEIXI ARC AND RECYCLED UPPER TRIASSIC STRATA OF THE QAMDO BASIN. CRETACEOUS UPLIFT AND EXHUMATION OF THE JOMDA-WEIXI ARC MAY RELATED TO THE UNDERTHRUSTING OF THE LHASA BLOCK BENEATH THE QIANGTANG BLOCK (KAPP ET AL., 2003; 2005; TIAN ET AL., 2014).

\section{CHAPTER II}

FiguRE 1. REGIONAL MAP. (A) GLOBAL PALEOGEOGRAPHIC MAP OF MID-CRETACEOUS ( 90 MA) SHOWING GENERAL LOCATION OF THE STUDY AREA IN SOUTHEASTERN TIBET (RED SQUARE). FIGURE ADAPTED FROM JARVIS ET AL. (2011) BASED ON THE PALEOGEOGRAPHIC RECONSTRUCTION OF BLAKEY (BLAKEY, 2008) (B) SIMPLIFIED GEOLOGICAL MAP OF SOUTHWESTERN CHINA SHOWING MAJOR TECTONIC UNITS AND BLOCK BOUNDARIES (PAN ET AL., 2004). (C) LOCAL GEOLOGIC MAP OF MARKAM AREA, EASTERN TiBET (PAN ET AL., 2004).

FIGURE 2. FIELD PHOTOS OF CRETACEOUS SECTION AND INDIVIDUAL PALEOSOL PROFILES. (A) OVERVIEW OF CRETACEOUS STRATA COMPOSED OF CLAST-SUPPORTED CONGLOMERATE, CROSS-STRATIFIED PEBBLY RED SANDSTONE, AND THICK-BEDDED CARBONATE NODULE-BEARING PALEOSOL LAYERS. LETTERS IN WHITE TRIANGLE INDICATE POSITIONS OF INDIVIDUAL PALEOSOLS SHOWN IN FIGS. 2B-E. (B-E) SEDIMENTARY LOGS AND PHOTOGRAPHS OF INDIVIDUAL PALEOSOL PROFILES, SHOWING BK-DEPTH AND PEDOGENIC FEATURES SUCH AS ROOT TRACES, BIOTURBATIONS, COLOR MOTTLING, PED STRUCTURES AND CARBONATE NODULES ....................85

FigURE 3. STRATIGRAPHIC COLUMN AND AGE CONTROL. (A) CHRONOSTRATIGRAPHY OF THE CRETACEOUS SEQUENCE. BIOSTRATIGRAPHIC CONTROLS ARE COMPILED FROM (GSX, 2007), ALONG WITH THE PALYNOLOGICAL DATA OBTAINED IN THIS STUDY. BLACK ARROWS INDICATE POSITIONS WHERE FOSSILS WERE FOUND IN CRETACEOUS REFERENCE SECTION. CORRELATIONS AMONG THE CRETACEOUS REFERENCE SECTION, SECTIONS A-A', AND C-C' ARE BASED ON LITHOLOGICAL MARKER BEDS. BLACK DOTS INDICATE PALYNOLOGY SAMPLING POSITIONS IN THE STUDIED SECTIONS. PALAEOMAGNETIC DATA ARE FROM HUANG ET AL. (1992) (SAMPLING LOCATIONS ARE MARKED IN FIG. 3B BY BLACK STAR SIGNS), CORRELATED TO THE SECTIONS IN THIS STUDY. (B) LOCAL GEOLOGIC AND SATELLITE MAPS SHOWING THE STUDIED SECTIONS

FiguRE 4. PHOTOMICROGRAPHS OF STUdiED CARBONATE NODULES. (A-D) PHOTOMICROGRAPHS TAKEN UNDER POLARIZED LIGHTS SHOWING DOMINANT MICRITIC CALCITE GROUNDMASS WITH VARIABLE AMOUNTS OF DETRITAL QUARTZ GRAinS AND SOIL COLOR MOTTLING FEATURE. (E, F) PHOTOMICROGRAPHS OF CARBONATE CEMENT SHOWING CRACK-FILLING SPAR CALCITE (UNDER POLARIZED LIGHTS). ONLY THE AREAS WITH HOMOGENEOUS MICRITIC TEXTURES WERE SAMPLED FOR CLUMPED ISOTOPIC ANALYSES 98

FIGURE 5. fl47-TEMPERATURE, d18OWATER, AND ATMOSPHERIC CO2 (PCO2) ESTIMATED FROM MARKAM PALEOSOLS. NOTE THAT THE BLACK AND RED DIAMONDS REPRESENT SAMPLES FROM TWO DIFFERENT SECTIONS (A-A' AND SECTION C-C', RESPECTIVELY), WITH ASSOCIATED ERROR BARS. SAMPLES WERE ASSIGNED AS EITHER: CENOMANIAN (BLUE SHADING); CENOMANIAN-TURONIAN TRANSITION (RED SHADING); OR TURONIAN (GREEN SHADING). (A) fl47-TEMPERATURE ESTIMATES ARE BASED ON THE INORGANIC CALIBRATION OF TRIPATI ET AL. (2015), GENERATED ON THE SAME INSTRUMENT, PLOTTED WITH SIMULATED MEAN ANNUAL SURFACE-AIR TEMPERATURE (MAAT) OF SOUTHEASTERN TIBET DURING MID-CRETACEOUS (KUMP AND POLLARD, 2008). (B) CALCULATED OXYGEN ISOTOPE VALUES OF SOIL WATER (d18OWATER). (C) ESTIMATED PCO2 LEVELS FROM MARKAM PALEOSOL RECORD, PLOTTED WITH PCO2 ESTIMATES FROM PREVIOUS STUDIES: 1. PCO2 ESTIMATES FROM GEOCHEMICAL MODELS (BERGMAN ET AL., 2004; BERNER AND KOTHAVALA, 2001); 2. PCO2 ESTIMATES FROM STOMATAL DENSITY (BARCLAY ET AL., 2010) AND CARBON ISOTOPE OF MARINE SEDIMENTS (BICE ET AL., 2006). (D) CENOMANIAN-TURONIAN (C-T) TROPICAL SEA SURFACE TEMPERATURE ESTIMATES FROM ORGANIC GEOCHEMICAL PROXY (TEX86) (BORNEMANN ET AL., 2008; FORSTER ET AL., 2007) AND OXYGEN ISOTOPE RATIOS OF PLANKTONIC FORAMINIFERA BASED ON ASSUMED VALUES FOR WATER d18O (BORNEMANN ET AL., 2008)

FIGURE 6. CONSTRAINTS ON REGIONAL CLIMATE SENSITIVITY FOR THE MID-CRETACEOUS. BLACK AND RED DOTS INDICATE INDIVIDUAL SAMPLES FROM SECTIONS A-A' AND C-C’, RESPECTIVELY. REGRESSION LINES ARE 
GENERATED BASED ON ALL PALEOSOL SAMPLES. (A) CROSS-PLOT OF fl47-T AND d18OWATER. SOLID BLACK LINE REPRESENTS BEST-FIT CORRELATION BETWEEN fl47-T AND PCO2. POINTS PLOTTED ABOVE THE LINE LIKELY REPRESENT EFFECTS OF SOIL EVAPORATION. (B) CROSS-PLOT OF fl47-TEMPERATURES (fl47-T) AND ESTIMATED PCO2 LEVELS. SOLID BLACK LINE REPRESENTS BEST-FIT CORRELATION BETWEEN fl47-T AND PCO2, WHICH CORRESPONDS TO AN AVERAGE CLIMATE SENSITIVITY (fIT2X) OF $10^{\circ} \mathrm{C}$ PER CO2 DOUBLING. DASHED BLACK LINES MARK THE 95\% CONFIDENCE INTERVALS. DASHED BLUE LINE IS BASED ON THE CORRELATION BETWEEN TROPICAL SEA SURFACE TEMPERATURE (BORNEMANN ET AL., 2008; FORSTER ET AL., 2007) AND PCO2 DERIVED FROM MARKAM PALEOSOL RECORD

\section{CHAPTER III}

FIgURE 1. (A) TOPOGRAPHIC MAP OF THE TIBETAN PlATEAU (NGDR, 1999) SHOWING LOCATION OF THE STUDY AREA (RED SQUARE). (B) GLOBAL PALEOGEOGRAPHIC RECONSTRUCTION OF LATE CRETACEOUS. FIGURE ADAPTED FROM JARVIS ET AL. (2011) BASED ON THE PALEOGEOGRAPHIC RECONSTRUCTION OF BLAKEY (2008). RED SQUARE MARKS THE ESTIMATED LOCATION OF SE TIBET. (C) LOCAL GEOLOGIC (PAN ET AL., 2004) AND SATELLITE (DIGITAL GLOBAL, 215) MAPS OF THE MARKAM AREA, SHOWING LOCAL LITHOLOGY AND STRUCTURAL FEATURES AS WELL AS LOCATIONS OF THE TWO STUDIED SECTIONS (AFTER SHANG ET AL., IN REVIEW).

FIGURE 2. PALEOGEOGRAPHIC BOUNDARY CONDITIONS FOR THE CENOMANIAN, TURONIAN, CONIACIAN AND SANTONIAN TIME-SLICES USED IN CLIMATE SIMULATION, SHOWING ELEVATION AND BATHYMETRY (GETECH PLC). NOTE THAT THE AREA CORRESPONDS TO CURRENT DAY SE TIBET (MARKED BY BLACK SQUARE) IS ASSUMED TO HAVE RELATIVELY CONSTANT PALEOELEVATION (1000 \pm 200 M) DURING THE CENOMANIANSANTONIAN TIME

FIGURE 3. THIN-SECTION PHOTOS OF STUDIED CARBONATE NODULES. (A-C) THIN-SECTION PHOTOS OF PALEOSOL CARBONATE NODULES TAKEN UNDER POLARIZED LIGHTS SHOWING DOMINANT MICRITIC TEXTURE. DETRITAL QUARTZ GRAINS ARE ‘FLOATING’ IN MICRITIC GROUNDMASS. (D) PHOTOMICROGRAPH TAKEN UNDER POLARIZED LIGHTS SHOWING CRACK-FILLING SPARRY CEMENT. ONLY THE AREAS WITH HOMOGENEOUS MICRITIC TEXTURE WERE SAMPLED FOR CLUMPED ISOTOPIC ANALYSES

FIGURE 4. d13CCARBONATE, d18OCARBONATE, fl47-TEMPERATURE, d18OWATER AND 87SR/87SR VALUES PLOTTED WITH STRATIGRAPHIC DEPTH. FILLED CIRCLES REPRESENT SAMPLES FROM THE UPPER NANXING FORMATION (CONIACIAN-SANTONAIN IN AGE) ANALYZED IN THIS STUDY. FILLED SQUARES REPRESENT DATA FROM THE LOWER NANXING FORMATION (CENOMANIAN-TURONIAN IN AGE) COMPILED FROM SHANG ET AL., IN REVIEW. STRONTIUM ISOTOPE DATA ARE ALL OBTAINED IN THIS STUDY. PURPLE SHADING REPRESENTS 95\% CONFIDENCE INTERVAL (CI) OF STAGE-AVERAGED fl47-T AND d18OWATER MEANS

FigurE 5. MODEL-DERIVED SUMMER (I.E., JUNE, JULY, AUGUST, AND SEPTEMBER) SOIL TEMPERATURE ESTIMATES. SIMULATIONS REPRESENT TIME-AVERAGED CONDITIONS FOR FOUR GEOLOGIC TIME-SLICES: CENOMANIAN, TURONIAN, CONIACIAN, AND SANTONIAN. SOIL TEMPERATURES ARE MODELED FOR 25-65 CM DEPTH

Figure 6. MODEL-DERIVED SUMMER (I.E., JunE, JULY, AUGUST, AND SEPTEMBER) SEA SURFACE TEMPERATURE ESTIMATES. SIMULATIONS REPRESENT TIME-AVERAGED CONDITIONS FOR FOUR GEOLOGIC TIME-SLICES: CENOMANIAN, TURONIAN, CONIACIAN, AND SANTONIAN

Figure 7. MODEL-DERIVED SUMMER (I.E., JUNE, JUly, AUGUST, AND SEPTEMBER) WIND PATTERN (850 MB) AND PRECIPITATION ESTIMATES. SIMULATIONS REPRESENT TIME-AVERAGED CONDITIONS FOR FOUR GEOLOGIC TIMESLICES: CENOMANIAN, TURONIAN, CONIACIAN, AND SANTONIAN

Figure 8. (A) CLIMATE MODEL (HADCM3L) OUTPUT OF AVERAGE SOIL TEMPERATURE (AT SOIL DEPTH BETWEEN 25 CM AND 65 CM) FOR SE TIBET DURING THE CENOMANIAN, TURONIAN, CONIACIAN AND SANTONIAN TIME SLICES. RED SHADING MARKS 95\% CONFIDENCE INTERVAL (CI) OF THE MODELED MEAN SOIL TEMPERATURE FOR EACH MODELED GEOLOGIC STAGE. (B) PLOT OF fl47-SOIL TEMPERATURE WITH STRATIGRAPHIC HEIGHT. FILLED CIRCLES REPRESENT SAMPLES ANALYZED IN THIS STUDY, WHILE FILLED SQUARES REPRESENT DATA COMPILED FROM SHANG ET AL., IN REVIEW. PURPLE SHADING REPRESENTS 95\% CI OF THE STAGE-AVERAGED fl47-T VALUE. (C) THE CENOMANIAN-SANTONIAN TROPICAL SEA SURFACE TEMPERATURES (SSTS) FROM ORGANIC GEOCHEMICAL ANALYSIS (I.E., TEX86) OF OCEAN DRILLING CORES (BORNEMANN ET AL., 2008; FORSTER ET AL., 2007). BLUE SHADING MARKS THE PLACE WHERE > 95\% DATA POINTS LIE. (D) RELATIVE TEMPERATURE CHANGES OF fl47-SOIL T AND SST DURING THE CENOMANIAN-SANTONIAN INTERVAL. NOTE THE DECREASING SOIL TEMPERATURE TREND COMPARED WITH RELATIVELY STABLE SST TREND IN THE TURONIAN-SANTONIAN INTERVAL SUGGESTS THAT THE OBSERVED SOIL COOLING WAS UNLIKELY RESULTED FROM CONTEMPORANEOUS GLOBAL CLIMATE CHANGE.

FIGURE 9. SYNTECTONIC DEPOSITION OF THE LATE CRETACEOUS NAXING FORMATION INDICATED BY VARIATION OF 


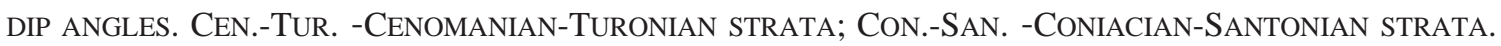

.158

FIGURE 10. CROSS-PLOT OF fl47-SOIL TEMPERATURE AND d18OWATER VALUES OF MARKAM PALEOSOL CARBONATES. RED DOT REPRESENTS SAMPLES FROM THE TURONIAN INTERVAL (COMPILED FROM SHANG ET AL., IN REVIEW) AND BLUE DOT MARKS THE DATA ANALYZED IN THIS STUDY

\section{LIST OF TABLE}

\section{CHAPTER I}

TABLE 1. U-PB AGE POPULATIONS AND THEIR PRECENTAGES IN EACH DETRITAL ZIRCON SAMPLES

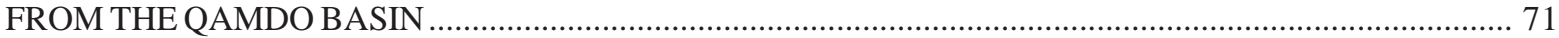

TABLE 2. P-VALUES FROM K-S STATISTICAL TEST OF TOTAL DETRITAL ZIRCON POPULATIONS ......... 73

TABLE 3. P-VALUES FROM K-S STATISTICAL TEST OF MESOZOIC MAGMATIC ARC-DERIVED DETRITAL

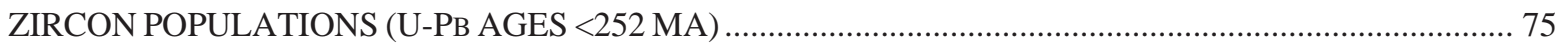

TABLE 4. P VALUES FROM K-S STATISTICAL TEST OF PRE-MESOZOIC DETRITAL ZIRCON

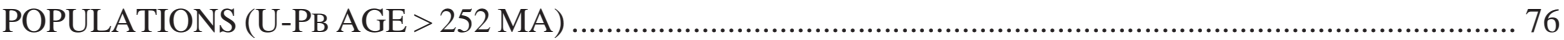

CHAPTER II

TABLE 1. SAMPLE MINERALOGY AS DETERMINED BY XRD, MG/CA, AND SR/CA RATIOS ...........................................96

TABLE 2. ISOTOPIC VALUES OF MICRO-SAMPLED MICRITIC AND CO-EXISTING SPARRY CLACITE $\ldots . . . . . . . . . . . . . . . . . . . . . . . . . . .99$

TABLE 3. STABLE ISOTOPE DATA INCLUDING CLUMPED ISOTOPE RESULTS. TEMPERATURES CALCULATED USING THE INORGANIC CALIBRATION OF TRIPATI ET AL. (2015), GENERATED ON THE SAME INSTRUMENT ..........................102

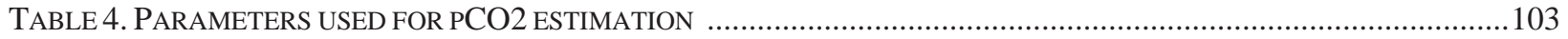

CHAPTER III

TABLE 1. RESUltS OF XRD, MG/CA AND SR/CA RATIOS, AND STRONTIUM ISOTOPE ANALYSES ...............................142

TABLE 2. ISOTOPIC VALUES OF MICRO-SAMPLED MICRITE AND CO-EXISTING SPARRY CEMENT ................................143

TABLE 3. STABLE ISOTOPE DATA INCLUDING CLUMPED ISOTOPE ANALYSIS RESULTS. TEMPERATURES CALCULATED USING THE INORGANIC CALIBRATION OF TRIPATI ET AL. (2015), GENERATED ON THE SAME INSTRUMENT .........144

TABLE 4. COMPARISON OF VARIATIONS OF SOIL AND MARINE TEMPERATURES IN RESPOND TO CENOMANIAN- TURONIAN

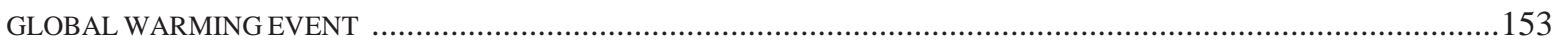




\title{
Chapter I
}

\section{Detrital zircon geochronology from the Mesozoic Qamdo (Changdu) basin southeastern Tibet: Implications for the Paleo- and Meso-Tethys evolution}

\author{
Fei Shang ${ }^{1, \dagger}$, Amy L. Weislogel ${ }^{1}$, Delores M. Robinson ${ }^{2}$, and William T. Jackson ${ }^{2}$ \\ ${ }^{1}$ Department of Geology \& Geography, West Virginia University, Morgantown, West Virginia \\ 26506, USA \\ †E-mail: fei-shang@utulsa.edu \\ ${ }^{2}$ Department of Geological Sciences, University of Alabama, Tuscaloosa, Alabama 35487, USA
}

\begin{abstract}
The Qamdo basin, which is bounded by the Paleo-Tethyan Jinsha suture to the northeast and the Meso-Tethyan Bangong-Nujiang suture zone to the southwest, contains up to 8,000 m of well-preserved Late Triassic-Cretaceous marine-continental sediments that record the evolution of southeastern Tibet prior to the development of the Cenozoic Tibetan plateau. Provenance analysis of Qamdo basin strata using sandstone petrology and detrital zircon geochronology techniques reveals the Mesozoic accretionary tectonism of southeastern Tibet. Quartzose Upper Triassic sandstone samples yield detrital zircon age signatures that form five primary populations at 230-330, 400-500, 700-1200, 1750-1900, and 2400-2600 Ma, consistent with derivation primarily from inversion and erosion of Triassic Yidun Group turbidites in response to the
\end{abstract}


closure of the Paleo-Tethyan Ganzi-Litang ocean. Lower Jurassic Lower Chaya Group samples are all composed of quartz-rich sandstone but show spatial provenance variation in detrital zircon ages. In the northern Qamdo basin, Lower Chaya Group has the same five primary detrital zircon age populations as the Upper Triassic sandstone; however, in the central Qamdo basin, Lower Jurassic sandstone detrital zircon age signatures are dominated by middle Paleoproterozoic ages (1840-1870 Ma) sourced from the Zhongza massif. The detrital zircon age signature of a Lower Jurassic sandstone sample from southern Qamdo basin is characterized by a prominent Triassic age peak (230-245 Ma), indicating sediment influx from the nearby Jomda-Weixi arc system. The lack of Jurassic-aged zircons in any of the Lower Jurassic strata may reflect a geographical separation between the coeval Bangong arc ( 170-190 Ma) and the Qamdo basin, possibly due to development of a back-arc oceanic basin.

Middle-Upper Jurassic Upper Chaya Group sandstone samples in northern and southern parts of the basin display largely similar quartzose framework grain composition and variable proportions of five main age populations: 230-330, 400-500, 700-1200, 1750-1900, and 24002600 Ma. In contrast, coeval sandstone samples from the central Qamdo basin show much greater abundance of volcanic lithic fragments and are characterized by a detrital zircon age signature with a prominent peak at $165-190$ Ma. We interpret that Middle-Upper Jurassic strata in the northern and southern Qamdo basin were mainly sourced from recycled Upper Triassic Qamdo strata, whereas Middle-Upper Jurassic deposits in the central Qamdo basin were sourced by erosion of the Bangong arc as a result of exhumation in response to Meso-Tethyan ocean closure and subsequent collision of the Qiangtang and Lhasa blocks. Sandstone samples of the Cretaceous Xiangdui Formation show a volcanic lithic-rich composition and a large detrital zircon age peak at 230-245 Ma, along with a secondary population of 1700-1950 Ma, suggesting 
Cretaceous strata were sourced primarily from the exhumed Jomda-Weixi arc to the southeast of the Qamdo basin, combined with locally recycled Upper Triassic Qamdo sediments. The Cretaceous exhumation of the Jomda-Weixi arc may be associated with the northward underthrusting of the Lhasa block beneath the Qiangtang block during Early Cretaceous time. These data depict a prolonged history of collisional tectonism that shaped the tectonic development of southeastern Tibetan plateau lithosphere prior to the initiation of early Cenozoic Himalayan orogenesis.

\section{INTRODUCTION}

Southeastern Tibet is a collage of continental fragments, volcanic arcs, and oceanic crustal rocks that were accreted successively to Eurasia during Paleozoic to Cenozoic time (Fig. 1) (e.g., Dewey et al., 1988; Yin and Harrison, 2000; Burchfield and Chen, 2013). Fragmentation, accretion, and deformation resulted from tectonism along several plate boundaries that have been reactivated numerous times (Yin and Harrison, 2000; Guynn et al., 2006; Kapp et al., 2007; Roger et al., 2008; Burchfield and Chen, 2013). The multi-phase tectonic history and overprinting by recent Cenozoic tectonic events makes reconstructing the pre-Himalayan, Mesozoic geologic history of southeastern Tibet very difficult (Tapponnier et al., 2001; Royden et al., 2008; Burchfield and Chen, 2013). Consequently, aspects of the evolution of Tibetan lithosphere prior to Himalayan orogenesis remain subject to debate. One of the outstanding issues is the role and timing of pre-Himalayan crustal shortening and its relationship to overall history of crustal thickening in the region, which is important in accurate geodynamic modeling of Tibetan plateau formation (e.g., Molnar and Tapponnier, 1975; Barazangi and Ni, 1982; Powell, 1986; Dewey et al, 1988; Holt and Wallace, 1990; Molnar et al., 1993; Wu et al., 
1993; Nelson and INDEPTH, 1996; Chang, 1997; Owens and Zandt, 1997; Yin and Harrison, 2000; Kind et al., 2002; Raphine et al. 2003; Kumar et al., 2006; Royden et al., 2008).

Although the modern Tibetan plateau is a topographic feature produced mainly by tectonism associated with the Cenozoic India-Asia collision (e.g., Dewey and Burke, 1973; Powell and Conaghan, 1973; Dewey et al., 1988), many studies across Tibet have documented crustal shortening, crustal thickening, and rapid cooling histories that predate the India-Asia collision (Murphy et al., 1997; Kapp et al., 2007; Studnicki-Gizbert et al., 2008). For example, Murphy et al. (1997) suggested that the Lhasa block underwent only 40\% of north-south crustal shortening during Cenozoic time and that $~ 60 \%$ of its current $70 \mathrm{~km}$ crustal thickness was developed during Early Cretaceous time, likely due to the collision of the Lhasa block with the Qiangtang block. Similarly, the Gonjo basin in eastern Tibet rests upon a pre-Cenozoic angular unconformity, which suggests at least some, if not most, of the shortening of Mesozoic rocks in the basin must have occurred prior to the India-Asia collision (Studnicki-Gizbert et al., 2008). In the Nima basin of central Tibet, the upper crust underwent $>47 \%$ shortening during Cretaceous to mid-Cenozoic time with more than half of this shortening predating the Indo-Asia collision (Kapp et al., 2007). All these studies indicate that a deeper understanding of pre-Cenozoic lithospheric configuration of Tibetan plateau is required in order to fully evaluate the mechanisms that may responsible for the Cenozoic development of the plateau (e.g., lower crustal flow and lithospheric delamination models) (e.g., Clark et al., 2000; Currie et al., 2005).

Estimation of pre-Cenozoic crustal shortening is often difficult in southeastern Tibet due to overprinting by younger, co-axial Cenozoic deformation and/or along-strike displacement of genetically related structures by strike-slip faulting (e.g., Studnicki-Gizbert et al., 2008). However, sedimentary basins adjacent to major convergent tectonic boundaries preserve a record 
of unroofing from adjacent mountains from which geodynamic processes associated with convergent tectonism can be inferred (Ingersoll et al., 2003). Although continuous, pre-Cenozoic sedimentary records are generally rare in southeastern Tibet, the Qamdo basin contains a relatively complete succession of Late Triassic-Cretaceous sedimentary rock $>8,000 \mathrm{~m}$ thick that is exposed across an area of $\sim 12,000 \mathrm{~km}^{2}$ (Fig. 1). The Qamdo basin rests on top of Precambrian and Paleozoic metamorphic basement of the eastern Qiangtang block, bound by the Jinsha suture to the northeast and the Bangong-Nujiang suture zone to the southwest (BNSZ) (Du et al., 1997; Pan et al., 2004). The basin strata preserve an important record of Mesozoic hinterland erosion and basin evolution in southeastern Tibet that was closely related to convergent deformation along both the Jinsha and Bangong-Nujiang sutures bordering the eastern Qiangtang block. Here, we investigate the provenance of Qamdo basin strata, which provides valuable constraints on the Mesozoic tectonic evolution and configuration of southeastern Tibetan lithosphere that was later modified by Cenozoic Himalayan orogenesis to become the modern Tibetan plateau.

We report framework grain compositions for 40 sandstone samples and >1,200 detrital zircon U-Pb ages from 14 sandstone samples of Upper Triassic-Cretaceous Qamdo basin strata in a first attempt to identify sediment source areas for this major basin system and assess the Mesozoic tectonic evolution of southeastern Tibetan lithosphere. In addition to study of Qamdo basin sedimentary rocks, we include 257 detrital zircon ages from 3 Yidun Group samples to further characterize the zircon $\mathrm{U}-\mathrm{Pb}$ age signatures of potential source rocks. Our results suggest that during Mesozoic time, sediment provenance of the Qamdo basin evolved from uniform, regional, far-field sources toward the east to more local sourcing by erosion of uplifted basinbounding ranges as paleogeography evolved in response to convergent tectonism associated with the closure of the Paleo- and Meso-Tethyan oceans. 


\section{GEOLOGICAL BACKGROUND}

\section{Tectonic Setting of the Qamdo Basin}

Qamdo basin strata rest unconformably on top of Precambrian and Lower TriassicPaleozoic metamorphosed sedimentary rocks of the eastern Qiangtang block (EQB) (Chang, 1997; Pan et a., 2004; Burchfield and Chen, 2013). The Jinsha suture delineates the northeastern EQB margin and records the closure of the Paleo-Tethyan ocean due to convergence of the EQB with the Yidun terrane (YDT) during Early-Middle Triassic time (Mo et al., 1993; Wang et al., 2000; Reid et al., 2007). To the southwest, the EQB abuts the Lhasa block (LHB) along the Bangong-Nujiang suture zone (BNSZ), which represents the closure of the Meso-Tethyan ocean between the EQB and LHB during Late Jurassic-Early Cretaceous time (e.g., Guynn et al., 2006, 2012; Kapp et al., 2007; Zhang et al., 2012). The Jitang arc (JTA) lies to the northeast of the BNSZ within the EQB, whereas the Bangong arc (BGA), and the LHB lie to the southwest of the BNSZ (Fig. 1B). These tectonic elements of southeastern Tibet are further described below.

\section{Yidun Terrane (YDT)}

The Yidun terrane (YDT) is comprised of the eastern Yidun terrane (EYDT) and Zhongza massif (ZM), which are separated by the north-south trending Xiangcheng-Geza fault (Fig. 1B; BGMRSP, 1991). The EYDT contains widespread, deformed Middle-Upper Triassic turbidite deposits of the Yidun Group (BGMRSP, 1991; Hou, 1993; Wang et al., 2014). These turbidites are intruded by Upper Triassic (216-219 Ma) granitic-dioritic intrusions commonly referred to as the 'Yidun' or 'Litang-Batang' arc (e.g., Pan et al., 2004). Triassic magmatic rocks of the EYDT are thought to have formed either as the result of the westward subduction of the Ganzi-Litang Ocean (e.g., Hou, 1993; Reid et al., 2007; Weislogel, 2008; Yang et al., 2014) or as 
the results of northward subduction along the Jinsha suture (Roger et al., 2008; Burchfield and Chen, 2013); whereas the Cretaceous (95-105 Ma) granitic intrusions are possibly related to subduction of the Meso-Tethyan oceanic crust underneath Asia and corresponding regional extension (Reid et al., 2007). The western YDT contains the ZM, which is intruded by plutons of the Permo-Triassic Jomda-Weixi arc (JWA).

\section{Zhongza Massif (ZM) and Jomda-Weixi Arc (JWA)}

The Zhongza massif (ZM) is thought to have originated as a micro-continent separated from the western South China block during Late Permian time based on similar Paleozoic fossil assemblages and sedimentary sequences between the South China craton and the ZM (BGMRSP, 1991; Hou, 1993; Song et al., 2004). The Neoproterozoic granitic gneiss basement and metamorphosed Paleozoic cover strata of the ZM were intruded by Permo-Triassic granitic plutons of the Jomda-Weixi arc, which yields U-Pb zircon ages of 230-245 Ma (Wang et al., 2010; Yang et al., 2011; Yang et al., 2014). The JWA may have been created by the westward subduction of Jinsha oceanic lithosphere (Mo et al., 1993; Wang et al., 2000; Xiao et al., 2008), although eastward subduction has also been proposed (Chang, 1997; Reid et al., 2005). The eastern side of the ZM is structurally overlapped by tightly folded Middle to Upper Triassic ( 245-220 Ma) clastic turbidites of the Yidun Group (Pan et al., 2004; Wang et al., 2013).

\section{Lhasa Block (LHB)}

The Lhasa block (LHB) consists mainly of Paleozoic and Mesozoic marine strata and arc-type volcanic rocks that are intruded by Jurassic through Early Tertiary granitoids of the Gangdese batholiths (Yin and Harrison, 2000). The block was accreted to the Eurasian plate along the Bangong-Nujiang suture zone (BNSZ), as the Meso-Tethyan oceanic basin closed 
during Late Jurassic to Early Cretaceous time (e.g., Dewey et al., 1988; Yin and Harrison, 2000;

Kapp et al., 2007; Zhang et al., 2012).

\section{Bangong Arc (BGA)}

The Bangong arc (BGA) is a proposed Jurassic continental magmatic arc system that parallels the length of the Bangong-Nujiang suture zone (BNSZ). BGA magmatism was fueled by the northward subduction of the Meso-Tethyan oceanic lithosphere (e.g., Girardeau et al., 1984; Leeder et al., 1988; Guynn et al., 2006; Zhang et al., 2012), however, much of the BGA was later subducted beneath the Qiangtang continental lithosphere as a result of the closure of the Meso-Tethyan ocean, leaving only scattered ophiolite belts and fragments exposed along the BNSZ (Fig. 1B; Pan et al., 2004; Guynn et al., 2006, 2012; Zhang et al., 2012). West of the Qamdo basin, the BGA intruded Cambrian-Neoproterozoic gneissic/granitic crystalline basement rocks of the Tongka basement (Fig. 1B) (Pan et al., 2004; He et al., 2011).

\section{Stratigraphy and Sedimentology of the Qamdo Basin}

From Late Triassic to Cretaceous time, Qamdo basin paleoenvironments evolved from deep-marine, to marginal-marine, to lacustrine, then to alluvial, indicating a continuous shallowing-upward trend over $\sim 100$ million years (Fig. 2). The $\sim 700$ m thick Upper Triassic (Carnian) Jiapila Formation is the basal unit of the Qamdo succession (Fig. 2). It is exposed only along the western Qamdo basin and disconformably underlain by Lower Triassic and Permian metaquartzite of the EQB (Fig. 2; Du et al., 1997). The Jiapila Foramtion is comprised of marine black shale with fine-grained turbidite sandstone interbeds (Fig. DR1A) interpreted to deposited in a deep-marine setting (Du et al., 1997; Peng et al., 2005). The overlying bioclastic Upper Triassic (early Norian) Bolila Formation is a 300 m thick carbonate platform deposit. The uppermost Triassic unit is the Upper Triassic (late Norian to Rhaetian) Bagang Group, which is 
comprised of $\sim 1,500 \mathrm{~m}$ thick siliciclastic strata and interlayered coal beds interpreted to have been deposited in a marginal marine/deltaic setting (Fig. DR1B; Peng et al., 2005).

Conformably overlying the Triassic marine-influenced deposits is the $\sim 4,300 \mathrm{~m}$ thick Jurassic Chaya Supergroup which can be further divided into the Lower Chaya (Lower Jurassic) and Upper Chaya (Middle-Upper Jurassic) groups (Fig.2; Du et al., 1997). The $800 \mathrm{~m}$ thick Lower Chaya Group is characterized by abundant well-developed red and purple paleosols interbedded with red lacustrine sandstone, siltstone, and mudstone (Fig. DR1C), representing a major transition of depositional environment from marginal marine to terrestrial. The Upper Chaya Group consists of $\sim 3,500 \mathrm{~m}$ thick interbedded red lacustrine fine-grained sandstone, siltstone, and mudstone, with occasional paleosol horizons (Fig. DR1D; Du et al., 1997). The sandstone/mudstone cyclothems occur from centimeter- to meter-scale recording periodic lake level fluctuations (Fig. DR1D, E), which may reflect both regional climatic- and tectonic-driven changes in sediment and runoff flux. Mud-cracks are common throughout the Upper Chaya Group (Fig. DR1F), indicating deposition occurred in a shallow lake setting with periodic desiccation. Erosional sedimentary structures (e.g., rip-up mud clasts; Fig. DR1G) are common, indicating strong currents alternated with periods of desiccations.

The Cretaceous Xiangdui Formation is only present in the southern Qamdo basin (Fig. 1; Du et al., 1997; Pan et al., 2004). It contains $~ 1,200$ m thick alluvial deposits composed of clastsupported cobble conglomerate, cross-stratified pebbly red sandstone, and thick-bedded carbonate nodule-bearing paleosol layers (Fig. DR1H, I, J). Abundant clast-supported conglomerate and calcisol layers suggest that deposition occurred proximal to source areas in an arid to semi-arid alluvial fan setting with periodic flooding. 


\section{METHODOLOGY}

\section{Field Procedures}

A total of 14 sandstone samples were collected from the Upper Triassic Jiapila Formation $(\mathrm{N}=1)$ and Bagang Group $(\mathrm{N}=3)$, the Jurassic Lower $(\mathrm{N}=4)$ and Upper $(\mathrm{N}=4)$ Chaya groups, and the Cretaceous Xiangdui Formation ( $\mathrm{N}=2$ ) of the Qamdo basin for paired sandstone petrology and detrital zircon geochronology provenance study. An additional 26 sandstone samples were collected from the same localities for thin-section petrographic study (Fig. 1B). Geologic maps produced by the Chengdu Institute of Geology \& Mineral Resources and China Geological Survey (Pan et al., 2004) were used to determine the locations and stratigraphic ages of the samples. Three additional sedimentary rock samples were collected from the Upper Triassic Yidun Group turbidites of the western YDT, a potential source area, with the purpose of characterizing its detrital zircon age signature. Paleocurrent orientation data include measurement of 31 cross-bedding structures from the Cretaceous Xiangdui Formation in the south Qamdo basin (Fig. 1B). Unfortunately, statistically robust (e.g., n >10 for a signal site; Potter and Pettijohn, 2012) paleocurrent measurements cannot be obtained from Upper TriassicJurassic strata, as paleocurrent indicators (i.e., ripple marks and cross-bedding) are rare.

\section{Sandstone Petrography}

Standard petrographic thin-sections were made from 40 medium- to fine-grained Upper Triassic to Cretaceous sandstone samples. The thin-sections were stained for potassium feldspar and calcic plagioclase and a total of 400 point-counts were obtained using a step size of $0.5 \mathrm{~mm}$ for each thin-section to achieve a maximum error of $5 \%$ at $2 \sigma$ (Van der Plas and Tobi, 1965). Gazzi-Dickenson method was used to minimize grain-size effects (Dickinson, 1970; Ingersoll et al., 1984). The resulting framework grain estimations from point-counting were then plotted on 
provenance discrimination ternary plots after Dickinson et al. (1985) to aid in determining the tectonic setting of the sediment source area. Modal sandstone compositions are listed in Table DR1 ${ }^{*}$ and graphically displayed in Figure 3.

\section{Detrital Zircon Geochronology}

Sandstone samples were disaggregated and the dense mineral fraction was separated using hydraulic separation and heavy liquid separation; magnetic fraction was removed using a Frantz magnetic separator. Detrital zircon grains were mounted in epoxy without handpicking to prevent sampling bias. Mounts were then polished and imaged using reflected light and cathodoluminescence (CL) to reveal internal heterogeneity of each zircon grain so that analysis mixing two different age domains could be avoided. U-Pb isotopic composition of zircon grains was determined by laser-ablation multi-collector inductively coupled plasma-mass spectrometer (LA-MC-ICP-MS) in the Arizona LaserChron Center at the University of Arizona (Gehrels et al., 2008). The analytical method is described in Gehrels et al. (2008) and briefly summarized here. The mass spectrometer was equipped with a Photon Machines Analyte G2 excimer laser using a spot diameter of 30 or 35 microns. The ablated material is carried in helium into the plasma source of a $\mathrm{Nu} \mathrm{HR}$ ICPMS, and $\mathrm{U}, \mathrm{Th}$, and $\mathrm{Pb}$ isotopes can be measured simultaneously. All measurements are made using Faraday detectors for ${ }^{238} \mathrm{U},{ }^{232} \mathrm{Th},{ }^{208} \mathrm{~Pb}-{ }^{206} \mathrm{~Pb}$, and discrete

dynode ion counters for ${ }^{204} \mathrm{~Pb}$ and ${ }^{202} \mathrm{Hg}$ (Gehrels et al., 2008). Common- $\mathrm{Pb}$ was corrected using the Hg-corrected ${ }^{204} \mathrm{~Pb}$ and assuming an initial $\mathrm{Pb}$ composition from Stacey and Kramers (1975). Inter-element fractionation of $\mathrm{Pb} / \mathrm{U}$ was corrected using a standard Sri Lankan zircon with known age of 563.5 $\pm 3.2 \mathrm{Ma}$, and another zircon standard R-33 was used as a check standard. Zircon ages that are younger than ca. $1000 \mathrm{Ma}$ are based on common Pb-corrected ${ }^{206} \mathrm{~Pb} /{ }^{238} \mathrm{U}$ 
ratios, whereas ages older than ca. $1000 \mathrm{Ma}$ are based on common $\mathrm{Pb}$-corrected ${ }^{207} \mathrm{~Pb} /{ }^{206} \mathrm{~Pb}$ ratios.

The resulting interpreted ages were plotted on $\mathrm{Pb} / \mathrm{U}$ concordia diagrams (Fig. DR2) and relative age-probability diagrams (Fig. 5-9) using Isoplot 3.60 software (Ludwig, 2008). Uncertainties on individual analyses are given at the $1-\sigma$ level and plotted at the $2-\sigma$ level. Detrital zircon ages for each sample are displayed using both probability density plots (PDP), and kernel density estimation plots (KDE), which plots the ages as a set of Gaussian distributions but does not explicitly take into account the analytical uncertainties (Vermeesch, 2012). The KDE produces statistically more robust age distribution curves especially when data quantity and/or analytical precision are high (Vermeesch, 2012; DensityPlotter, version 6.3). Because DensityPlotter 6.3 cannot accept data sets with >1,000 ages due to software limitations, therefore, composite distributions composed of $>1,000$ ages are plotted only as PDPs. Results from all zircon isotopic measurements are available in Table DR2 in the Data Repository.

The detrital zircon analysis yielded 1275 valid ages from 14 Qamdo sandstone samples and additional 257 valid ages from 3 Yidun Group turbidite sandstone samples (Table DR2). Typically, 100-110 grains were analyzed per sample with 10-20 analyses rejected due to high discordance, high common-lead, or error, leaving 90 acceptable ages for each sample. According to Vermeesch (2004), 90 ages allows an 82\% confidence level that no fraction $\geq 5 \%$, or a $100 \%$ confidence level that no fraction $\geq 10 \%$ was not represented in the final results.

\section{Statistical Methods}

Detrital zircon age populations were compared using the Kolmogorov-Smirnov (K-S) test. The K-S test is an unbiased, statistically sound approach for comparing two distributions and determining if there is a significant difference between two distributions (Guynn and 
Gehrels, 2010). The P-values returned by the K-S test corresponds to the confidence level that age distributions of two samples are sourced from the same parent population. The K-S test was conducted using an Excel macro program (provided by George Gehrels, 2010). However, the Pvalues are not only affected by similarity between age distributions, but also factors such as: (1) number of analyses in each sample; (2) proportions of similar ages in samples; and (3) analytical uncertainty (Guynn and Gehrels, 2010). Thus, P-values are used as a secondary indicator for determining if two distributions share a sediment source area or not. Comparison of age distributions between the Qamdo sandstone samples and potential source areas are primarily conducted by determining the presence or absence of prominent age populations along with their relative proportions in different samples.

We conducted 3 K-S tests with results shown in Tables 2, 3, and 4. Results in Table 2 were generated from comparing all Qamdo detrital zircon samples with potential sources. In contrast, results in Table 3 were from comparison of only Mesozic grains ( $<252 \mathrm{Ma})$ in Qamdo samples and potential Mesozoic magmatic arc sources compiled from previous studies (Guynn et al., 2006; Reid et al., 2007; Wang et al., 2010; Yang et al., 2011; Peng et al., 2014; Tao et al., 2014; Wang et al., 2014). Most individual Qamdo detrital zircon samples contain <20 Mesozoic grains, which is insufficient to yield statistically valid K-S analysis results (Guynn and Gehrels, 2010). Thus, the comparisons were conducted between the Mesozoic grains combined from the Upper Triassic, Lower Jurassic, Middle-Upper Jurassic, and Cretaceous samples from the Qamdo basin and the zircon ages from potential magmatic arc sources. K-S test results in Table 4 are from comparison of pre-Mesozoic ages (>252 Ma) in Qamdo samples and pre-Mesozoic (>252 Ma) ages of potential sources complies from published literature (Reid et al., 2007; Gehrels et al., 2011), as well as from this study. 


\section{RESULTS}

\section{Sandstone Composition}

\section{Upper Triassic Jiapila Formation and Bagang Group}

Three Jiapila Formation and eight Bagang Group sandstone samples have very similar detrital framework compositions (Table DR1) with an average quartz abundance of 91\% (Table DR1). Monocrystalline quartz is the most abundant component (mean abundance $=86 \%$ ), while polycrystalline quartz is minor (mean abundance $=5 \%$ ) (Fig. 4A, Table DR1). Feldspar grains comprise an average of $5 \%$ of the samples and are dominated by plagioclase with minor albitization. Lithic fragments are rare and mainly sedimentary in origin (Table DR1).

\section{Lower Jurassic Lower Chaya Group}

Nine Lower Chaya Group samples were point-counted. Monocrystalline quartz is the dominant framework grain type in the Lower Chaya samples (mean abundance $=67 \%$ ). The samples contain 16-24\% polycrystalline quartz, and $2 \%$ feldspar dominated by plagioclase (Fig. 4B; Table DR1). Lithic component in the samples tend to vary spatially. The six samples analyzed from the northern and central Qamdo basin contain $\leq 10 \%$ lithic fragments, including sedimentary lithic fragments $(\sim 6 \%)$ and minor volcanic lithic grains $(<2 \%)$ (Fig. 4C). In contrast, the three samples analyzed from the southern Qamdo basin yield a greater abundance of lithic fragments $(\leq 20 \%)$, and show much higher content of volcanic lithic fragments $(\sim 16 \%)$ and lower abundances of sedimentary lithic grains $(<2 \%)$ (Figure. 3F; Table DR1).

\section{Middle-Upper Jurassic Upper Chaya Group}

In the twelve Upper Chaya Group samples, monocrystalline quartz is the most abundant component (mean abundance $=73 \%$; Fig. 4D). Polycrystalline quartz abundances average $11 \%$ 
(Table DR1). Feldspar makes up $\leq 3 \%$ of the total framework grains and lithic grains comprise another $\sim 16 \%$. Volcanic and sedimentary lithic fragments are the dominant lithic grain types, with average abundances of $\sim 11 \%$ and $\sim 5 \%$, respectively (Fig. 4E; Table DR1). The abundance of volcanic lithic grains varies significantly, with the highest volcanic lithic content ( 21\%) found in samples from the central Qamdo basin. In contrast, volcanic lithic fragments form just $\sim 4 \%$ of northern and southern Qamdo basin samples (Fig. 3I).

\section{Cretaceous Xiangdui Formation}

Nine Xiangdui Formation sandstone samples were point-counted. Monocrystalline and polycrystalline quartz abundances average $76 \%$ and $11 \%$, respectively (Table DR1). Lithic fragments comprise an average abundance of $15 \%$, and most lithic grains (>80\%) are volcanic fragments (Fig. 3L; Table DR1). The volcanic lithic fragments display both vitriclastic (Fig. 4F) and microlitic textures, suggesting derivation from both pyroclastic and plutonic igneous rocks. Sedimentary lithic fragments are rare (average $~ 3 \%$ ). Similar to Upper Triassic-Jurassic samples, feldspars are rare in Cretaceous sandstone samples (Table DR1).

\section{Detrital Zircon Age Analysis Results}

\section{Upper Triassic Jiapila Formation and Bagang Group}

One Jiapila (i.e., UT-2) and three Bagang (i.e., UT-1, UT-2, UT-4) detrital zircon samples were analyzed: two from north Qamdo (UT-1 and UT-2), and two from south Qamdo (UT-3 and UT-4) (Fig. 1B), which altogether yielded 349 valid ages. Over $80 \%$ of the ages form five primary age populations, including 15\%-27\% that form an Early Carboniferous-Middle Triassic (330-230 Ma) population, 8\%-17\% that form a Late Cambrian-Early Devonian (500-400 Ma) population, 6\%-17\% that form a Meso- to Neoproterozoic (1200-700 Ma) population, and 
$18 \%-51 \%$ and $8 \%-14 \%$ that form a late Paleoproterozoic (1950-1700 Ma) and a late Archeanearly Paleoproterozoic (2600-2400 Ma) populations, respectively (Fig. 6A; Table 1). Sample UT-1 differed from the others in that it also contains a population of ca. 220 Ma zircon grains that comprises $7 \%$ of the sample. $\mathrm{K}-\mathrm{S}$ comparison between Upper Triassic samples results in Pvalues range from 0 to 0.61 . There are 4 out of 12 sample pairs yielded P-values $>0.05$ and 8 out of 12 sample pairs yielded P-values >0.01 (Table 2).

\section{Lower Jurassic Lower Chaya Group}

Four Lower Chaya Group samples were analyzed: sample LJ-1 from north Qamdo, samples LJ-2 and LJ-4 from central Qamdo, and sample LJ-3 from south Qamdo (Fig. 1B). Together, the samples yielded 364 valid ages. In north Qamdo, sample LJ-1 has a detrital zircon signature similar to that of the Upper Triassic Qamdo samples with the same five major age populations comprising $81 \%$ of total ages, including 17\% that form an Early CarboniferousMiddle Triassic (330-230 Ma) population, 20\% that form a Late Cambrian-Early Devonian (500$400 \mathrm{Ma}$ ) population, $15 \%$ that form a Meso- to Neoproterozoic (1200-700 Ma) population, and $25 \%$ and $5 \%$ that form a late Paleoproterozoic (1950-1700 Ma) and a late Archean-early Paleoproterozoic (2600-2400 Ma) populations, respectively (Fig. 6B; Table 1). In addition, 7\% of ages comprise a minor young peak at ca. $220 \mathrm{Ma}$ (Table 1).

In contrast, samples LJ-2 and LJ-4 from central Qamdo display largely similar detrital zircon age populations as LJ-1, but with significantly more middle Paleoproterozoic (1870-1840 Ma) ages (Fig. 6B). Samples LJ-2 and LJ-4 contains $22 \%$ and $15 \%$ of zircon ages between 1870 1840 Ma, respectively, whereas sample LJ-1 only contains 9\% ages of 1870-1840 Ma (Fig. 6B; Table 1). 
Sample from south Qamdo (i.e., LJ-3) is distinguishable from the north and central Qamdo samples by a prominent Middle Triassic age peak at 245-230 Ma, which comprises 20\% of total zircon grain ages (Fig. 6B; Table 1). In comparison, other coeval sandstone samples from north and central Qamdo (i.e., LJ-1, LJ-2 and LJ-4) contain <6\% of 245-230 Ma zircon grains (Table 1). Other primary age populations of sample LJ-3 include a Meso- to Neoproterozoic (1200-700 Ma) population (19\% of total grains), and a middle Paleoproterozoic (1870-1840 Ma) population (14\% of total grains, Fig. 6B; Table 1).

K-S comparison between Lower Jurassic samples yield P-values range from 0 to 0.46, while half of the sample pairs display P-values $<0.05$ (Table 2). The relatively low P-values suggest sediment provenance varied spatially during deposition of Lower Jurassic strata.

\section{Middle-Upper Jurassic Upper Chaya Group}

Four Upper Chaya Group detrital zircon samples were analyzed: MUJ-1 and MUJ-4 from north Qamdo; MUJ-2 from central Qamdo; and MUJ-3 from south Qamdo (Fig. 1B). Together, the samples yielded 363 valid ages. Samples from north (i.e., MUJ-1, MUJ-4) and south (i.e., MUJ-3) Qamdo display largely similar detrital zircon age distributions with $75 \%-84 \%$ of the ages forming the same five primary age populations observed in most older (i.e., Upper TriassicLower Jurassic) Qamdo samples, including 14\%-27\% that form an Early Carboniferous-Middle Triassic (330-230 Ma) population, 14\%-16\% that form a Late Cambrian-Early Devonian (500$400 \mathrm{Ma}$ ) population, $10 \%-25 \%$ that form a Meso- to Neoproterozoic (1200-700 Ma) population, and $19 \%-23 \%$ and 3\%-10\% that form a late Paleoproterozoic (1950-1700 Ma) and a late Archean-early Paleoproterozoic (2600-2400 Ma) populations, respectively, along with few Early-Middle Jurassic grains at $\sim 165, \sim 185$, and $\sim 188$ Ma (Fig. 7A; Table 1). In contrast, 33\% of zircon grains in sample MUJ-2 from central Qamdo yielded ages between 165-190 Ma, forming 
a prominent Early-Middle Jurassic peak (Fig. 7A). In MUJ-2, subordinate age populations include Early Carboniferous-Middle Triassic (330-230 Ma; $32 \%$ of total grains), Meso- to Neoproterozoic (1200-700 Ma; 5\% of total grains), late Paleoproterozoic (1950-1700 Ma; $7 \%$ of total grains), and late Archean-early Paleoproterozoic (2600-2400 Ma; 5\% of total grains), as were observed in other Qamdo samples (Table 1). K-S comparison between MUJ-1, MUJ-3 and MUJ-4 results in P-values range from 0.12 to 0.74 , whereas the comparison of MUJ-2 with other Middle-Upper Jurassic samples all yields P-values $=0$ (Table 2). These results indicate that MUJ1, MUJ-3 and MUJ-4 have a similar provenance, whereas MUJ-2 incorporated detritus derived from additional source/sources.

\section{Cretaceous Xiangdui Formation}

Two Cretaceous detrital zircon samples, K-1 and K-2, yielded 199 valid ages. Samples were collected from the southern Qamdo basin where Cretaceous strata are present (Fig. 1B). The detrital zircon signature of sample K-1 is characterized by a bimodal age distribution with a prominent Middle Triassic (245-230 Ma) population that comprises 33\% of the total ages, along with a late Paleoproterozoic (1950-1700 Ma) population that makes up of 30\% of total ages (Fig. 7B; Table 1). In contrast, for sample K-2, the 245-230 and 1950-1700 Ma age populations are much less abundant, and both populations comprise only $10 \%$ of total ages. However, the Early Carboniferous-Early Triassic (330-250 Ma; $18 \%$ of total ages), Late Cambrian-Early Devonian (500-400 Ma; $14 \%$ of total ages), and Meso- to Neoproterozoic (1200-700 Ma; $21 \%$ of total ages) ages are more abundant in K-2 compared to K-1 (Fig. 7B; Table 1). K-S comparison between $\mathrm{K}-1$ and $\mathrm{K}-2$ results in P-values $=0.07$, suggesting a similar provenance between the two samples (Table 2). 


\section{Summary of K-S Comparison of Qamdo Zircon Age Distributions}

K-S test results are shown in Tables 2, 3, and 4. Results of K-S comparison suggest that most Qamdo samples have similar provenance. P-values that result from comparing all Qamdo detrital zircon samples to each other suggest that 10 out of 14 samples (i.e., UT-1, 2, 3; LJ-1, 3, 4; MUJ-1, 3, 4; K-2) have age distributions similar to each other, with P-values $>0.05$ for $71 \%$ of sample pairs (Table 2). Only 4 samples (i.e., UT-4; LJ-2; MUJ-2; K-1) show relatively low similarity compared to the other samples, as reflected by only $11 \%$ of sample pairs with P-values $>0.05$ (Table 2). This is largely because these 4 samples contain more abundant Mesozoic grains. Comparison of Mesozoic ( $<252 \mathrm{Ma}$ ) ages among Qamdo composite samples show high P-values (>0.05) for the Upper Triassic, Lower Jurassic, and Cretaceous composite sample pairs (Table 3), indicating the Mesozoic zircon grains in Qamdo basin were likely sourced from similar source/sources. Note that comparisons among the Middle-Upper Jurassic composite sample and the Upper Triassic/Lower Jurassic/Cretaceous composite samples all returned low Pvalues $(\mathrm{P}<0.05)$. We attribute these low values to the presence of $165-190$ Ma population in the Middle-Upper Jurassic composite sample that is missing in other composite samples (Fig. 8). KS comparison of pre-Mesozoic (>252 Ma) ages for all Qamdo samples returned P-values $>0.05$ for $53 \%$ of the sample pairs (Table 4), suggesting the pre-Mesozoic grains have a general similarity in provenance, but with locally varied sediment influx.

\section{COMPARISION WITH POTENTIAL SOURCES OF QAMDO BASIN FILL}

Given regional Mesozoic paleogeographic reconstructions and estimated strike-slip movements along Qamdo basin boundary faults (e.g., Jinsha and Bangong-Nujiang sutures) (Yin and Harrison, 2000; Metcalfe, 2009; Gehrels et al., 2011), possible source terranes for the Qamdo basin include the neighboring Zhongza massif (ZM), Jomda-Weixi arc (JWA), eastern 
Yidun terrane (EYDT), Qiangtang block (QTB), Lhasa block (LHB), Jitang arc (JTA), and Bangong arc (BGA) (Fig. 1B). In addition, older sedimentary rock of the Qamdo basin can be a potential source for its younger strata because structural estimations suggest shortening of the Qamdo basin beginning by Early Jurassic time (Du et al., 1997; Pan et al., 2004). Thus, folding of pre-Early Jurassic strata generated uplifted fold-thrust belts (e.g., Zhongza thrust system, Xu et al., 2015) that could have served as a sediment source. Published U-Pb zircon ages from detrital, metamorphic, and magmatic rocks of the previously mentioned source terranes, along with detrital zircon ages of the Yidun Group from this study are used to generate reference zircon age signatures of the eight potential sources. Zircon age probability density plots and kernel density plots of all the source areas are shown and compared in Figures 5, 8, and 9.

\section{Eastern Yidun Terrane (EYDT) Signature (Sources to the N-NE of Qamdo Basin)}

Basement rocks of the eastern Yidun terrane (EYDT) are not widely exposed, and are limited to the Neoproterozoic-Paleozoic rocks of the Zhongza massif (ZM) exposed along the Jinsha suture (discussed separately). The detrital zircon signature of EYDT is characterized using 257 detrital zircon ages from three Yidun Group turbidite sandstone samples dated in this study (i.e., 13UTSG-1, 13UTSG-2, and 13UTSG-427; Fig. 1B). Detrital zircon age signature of the Yidun Group is characterized by five major age populations of Early Carboniferous-Middle Triassic (330-230 Ma; 18\% of total grains), Late Cambrian-Early Devonian (500-400 Ma; 14\% of total grains), Meso- to Neoproterozoic (1200-700 Ma; $16 \%$ of total grains), late Paleoproterozoic (1950-1700 Ma; 23\% of total grains), and late Archean-early Paleoproterozoic (2600-2400 Ma; $12 \%$ of total grains; Fig. 5D; Table DR2). U-Pb analyses of widespread granodiorite intrusions within the EYDT yielded mainly Late Triassic (225-215 Ma) and Cretaceous (105-95 Ma) ages (Fig. 8A; Reid et al., 2007; Peng et al., 2014). 


\section{Evidence for EYDT Provenance}

The Middle-Upper Triassic (Ladinian-Carnian) Yidun Group is a potential source for the Upper Triassic (Carnian-Rhaetian) and younger strata of Qamdo basin. Comparison of detrital zircon age signatures between the Yidun Group and Upper Triassic Qamdo composites (Figs. 5D-E) suggests they contain almost identical primary age populations (i.e., 230-330; 400-500; 700-1200; 1700-1950, 2400-2600) with similar age percentages. K-S test comparisons of Upper Triassic detrital zircon ages with the Yidun Group composite yield P-values >0.05 (range from 0.11 to 0.72 ) for 2 out of 4 sample pairs, indicating relatively high probability of a shared parent source of detrital zircons (Figs. 5D-E; Table 2). K-S analyses also reveal high correlations between the Yidun Group samples and the Jurassic and Cretaceous Qamdo samples, with Pvalues $>0.05$ (range from 0.18 to 0.87 ) for $56 \%$ of total sample pairs (Table 2).

\section{Zhongza Massif (ZM) and Jomda-Weixi Arc (JWA) (Sources to the N-NE of Qamdo Basin)}

Although zircons from basement rocks of the Zhongza massif (ZM) have not been directly dated, $\mathrm{U}-\mathrm{Pb}$ dating of a pegmatite sample from an Early-Middle Triassic granitic pluton that intruded the ZM revealed inherited zircon cores that are dominantly middle Paleoproterozoic in age (1870-1840 Ma; 32\% of total grains), along with a few $\sim 500, \sim 750$, and $\sim 1700$ Ma cores (Figs. 5F; Reid et al., 2007). These grains were interpreted to be scavenged from Paleozoic metasedimentary rocks of the ZM that experienced partial melting during the Paleo-Tethyan Jinsha ocean subduction (Reid et al., 2007). The age signature of the inherited ZM zircon grains displays South China block affinity, as the $\sim 1800$ Ma zircon grains are commonly reported as inherited cores of the South China block (Qiu et al., 2000; Zhang et al., 2006). The 750 Ma grains are similar in age to extensive Neoproterozoic magmatic rocks within the western South China block (Li et al., 2003). Neoproterozoic basement rocks of the ZM were intruded by the 
Permian-Triassic plutons of the JWA, which contains abundant 230-245 Ma zircons (Wang et al., 2010; Yang et al., 2011; Yang et al., 2014).

\section{Evidence for ZM and JWA Provenance}

Although Paleoproterozoic ( 1700-1950 Ma) zircon ages are common in most Qamdo samples, abundant 1840-1870 Ma zircon is often coincident with abundant Middle Triassic ages at 230-245 Ma (e.g., in samples LJ-3 and K-1). Together these ages indicate sediment influx from the ZM and the JWA (Reid et al., 2007). K-S tests conducted between the ZM basement and the pre-Mesozoic ages of Qamdo samples returned P-values >0.05 (range from 0.07 to 0.49) for 9 out of 14 Qamdo samples (Table 4) and K-S comparisons between the composite Mesozoic ages of Qamdo samples and the JWA shows P-values >0.05 (range from 0.06 to 0.33 ) for 3 out

of 4 sample pairs (Table 3), suggesting the ZM and JWA were important sources for Qamdo sediments.

\section{Qiangtang Block (QTB) Signature (Local Sources of QTB)}

The Qiangtang block (QTB) is composed of the south and north Qiangtang terranes separated by a high-pressure eclogite-blueschist metamorphic belt exposed in central QTB (e.g., Metcalfe, 1988; Zhang, 2001). Composite detrital zircon age plot for the north Qiangtang terrane (Fig. 5B) was compiled from 12 samples from Caboniferous-Triassic strata collected across the north Qiangtang terrane (Fig. 1A; Pullen et al., 2010; Gehrels et al., 2011). The south Qiangtang composite (Fig. 5C) was constructed using 21 Precambrian-Triassic samples collected from various locations of the north Qiangtang terrane (Pullen et al., 2010; Gehrels et al., 2011). Although in different proportions, the south and north Qiangtang terranes yield the same zircon age populations of 210-280, 500-650, 750-1000, 1800-2000, and 2400-2600 Ma (Figs. 5B-C; Pullen et al., 2010; Gehrels et al., 2011). 


\section{Evidence for Qiangtang Provenance}

Although the Qamdo basin was developed on top of the eastern QTB (Du et al., 1997; Pan et al., 2004), a lack of 500-650 Ma ages in the Qamdo sedimentary rock ( $<3 \%$ of total grain counts; Figs. 6-7), which are prevalent in the Qiangtang terranes (Figs. 5B-C), indicates the QTB is not a major source for the Qamdo sedimentary rock. The relationship is also indicated by K-S comparisons between the Qiangtang terranes and Qamdo samples, which all yield P-values of zero (Tables 2; 4).

\section{Recycled Upper Triassic Qamdo Strata (Local Sources of QTB)}

As previously discussed, recycled Upper Triassic Qamdo strata could be a potential source for Jurassic-Cretaceous sediments of the Qamdo basin because all characteristic age populations found in Upper Triassic samples (i.e., 230-330, 400-500, 700-1200, 1700-1950, and 2400-2600 Ma) are present in Jurassic and Cretaceous Qamdo samples (Figs. 6B; 7), even in samples that have dominant volcanic arc provenance (e.g., LJ-3, MUJ-2, and K-1) based on zircon ages and sandstone compositions. Similarity between the Upper Triassic and the JurassicCretaceous samples becomes more pronounced when the Mesozoic arc-related ages are removed from consideration. Comparison of all pre-Mesozoic (>252 Ma) detrital zircon ages from the Qamdo basin, it is clear that except for the abundant middle Paleoproterozoic (1870-1840Ma) grains derived from ZM basement rocks that are present in couple Lower Jurassic samples (i.e., LJ-2 and LJ-4), the Jurassic and Cretaceous samples have almost identical detrital zircon signatures as those of the Upper Triassic samples (Fig. 9). The similarity is also supported by K$\mathrm{S}$ analyses comparing Jurassic and Cretaceous samples with the Upper Triassic composite, which show P-values $>0.05$ (range from 0.05 to 0.54 ) for 7 out of 10 sample pairs (Table 4 ). The 
recycled origin of Jurassic-Cretaceous deposits is also supported by sandstone petrology data, which reveal QFL ratios indicative of recycled orogen provenance (Fig 3D-L).

However, since the Upper Triassic Yidun Group of the EYDT has almost identical detrital zircon age signatures as those of the Upper Triassic Qamdo strata based on both visual comparison and K-S tests (Figs. 5D-E; Table 2), it is possible the 'recycled signature' was related to sediment influx from the Yidun Group rather than recycling of the Upper Triassic Qamdo strata. However, geologic context of the Qamdo basin suggests that the Yidun Group was likely not a major source area for the Qamdo basin during Jurassic through middle Cretaceous time: (1) tectonic deformation of the EYDT likely ceased by ca. 190-200 Ma (Reid et al., 2005), with a subsequent episode of exhumation during Late Cretaceous (Reid et al., 2005; Roger et al., 2008; Jackson et al., 2014; Wang et al., 2014a); and (2) Significant shrinkage of basin size and transition from marine (Fig. DR1A-B) to arid and semi-arid terrestrial environments (Fig. DR1CF) in the Qamdo basin by Early Jurassic time (Du et al., 1997; Pan et al., 2004) favors development of an internally-drained basin system (e.g., Carroll and Bohacs, 1999; Sobel et al., 2003; Garcia-Castellanos, 2006; Carroll et al., 2010), which therefore favors reworking of the proximal Upper Triassic strata compared to transport of sediments from distal sources in the EYDT. Continued uplift and exhumation of the Upper Triassic Qamdo strata may have been associated with development of the Zhongza thrust belt along the Jinsha suture in latest Triassic as a result of Paleo-Tethyan closure (Xu et al., 2015), and subsequent Jurassic-middle Cretaceous continental-continental collision between the Qiangtang and Lhasa blocks along the BNSZ (Zhang et al., 2012; Wang et al., 2014a; Liu et al., 2015). However, recent thermochronology study of the Yidun terrane reveals an episode of Late Jurassic-Early Cretaceous crustal exhumation that is interpreted to induced by flat-slab subduction of the Meso-Tethys ocean (Tian 
et al., 2014), which indicates that the Yidun rocks may be uplifted during Late Jurassic-Early

Cretaceous time to source sediment of the Qamdo basin. Therefore it is possible that the recycled Upper Triassic Qamdo strata and EYDT may have both been sources of Jurassic-Cretaceous Qamdo deposits.

Jitang Arc (JTA) Signature (Local Sources of QTB)

The Jitang arc (JTA) is located along the western side of the Qamdo basin (Fig. 1B) and formed by melts derived from a crustal source with $\mathrm{Sr}-\mathrm{Nd}$ isotopic compositions similar to those of the Indian cratonic crust (Tao et al., 2014). U-Pb zircon age information available for this arc

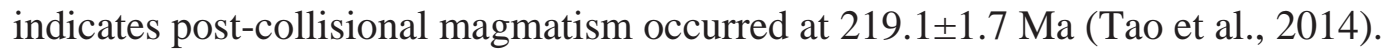

\section{Evidence for JTA Provenance}

Despite close geographic proximity between the JTA and the Qamdo basin, the absence of ca. 220 Ma zircon grains in most Qamdo sedimentary rocks suggests JTA rocks were not a major sediment source for the basin (Table 1). Exceptions are samples UT-1, LJ-1, and K-2, which contain a minor peak at $\sim 220 \mathrm{Ma}$ (Table 1) and were all collected from areas adjacent to the JTA (Fig. 1B). Although Triassic magmatic arcs of the eastern Yidun terrane (EYDT) also contain a minor ca. 220 Ma population (Fig. 8A; Reid et al., 2007), the very localized occurrence of ca. $220 \mathrm{Ma}$ zircon grains in the Qamdo basin and lack of age signature of Triassic plutons of the EYDT (i.e., 215-225 Ma) suggest these young grains were most likely sourced locally from the nearby JTA instead from the distant EYDT. The paucity of JTA aged zircon grains in Qamdo sediments indicates that the JTA may only have experienced limited magmatism and exhumation during Mesozoic time and detritus derived from the arc did not travel far into the Qamdo basin, or perhaps the Mesozoic drainage pattern did not favor the transportation of JTA detritus into the 
Qamdo basin, and the detritus shed from the exhumed JTA was routed elsewhere (e.g., to the SSW toward the Lhasa block)

\section{Lhasa Block (LHB) Signature (Sources to the S-SW of Qamdo Basin)}

Granitic basement of the LHB contains abundant Cambrian zircon grains dated at 480$520 \mathrm{Ma}$, along with a few inherited zircons with ages of $\sim 613$ and $~ 875 \mathrm{Ma}$ (Leier et al., 2007; Pullen et al., 2010; Gehrels et al., 2011). Detrital zircons in the overlying Paleozoic and Mesozoic cover strata also yield mainly Cambrian ages with a peak at $511 \mathrm{Ma}$ (Fig. 5A), probably derived from the underlying granite basement of the LHB (Leier et al., 2007; Pullen et al., 2010; Gehrels et al., 2011). Here, the composite detrital zircon age plot of LHB (Fig. 5A) was constructed from compiling the samples from a Paleozoic sequence and the overlying Jurassic-Lower Cretaceous strata from central LHB (Leier et al., 2007; Pullen et al., 2010; Gehrels et al., 2011).

\section{Evidence for Lhasa Provenance}

Cambrian zircons ( 480-540 Ma) that are abundant in the LHB rocks are rare to absent in most Mesozoic Qamdo samples (Fig. 9). At most, the age population of 480-540 Ma forms <5\% of Qamdo samples. K-S comparisons of Lhasa composite and Qamdo samples all returned Pvalues $=0$ (Tables $2 ; 4)$, suggesting that the LHB was probably not contributing sediments into the Qamdo basin during Mesozoic time. The interpretation is consistent with the Mesozoic paleogeographic reconstructions of Tibet (Metcalfe, 2009; Gehrels et al., 2011), which suggest the LHB was separated from the Qiangtang block by Late Jurassic time. Subsequent closure of the Meso-Tethyan ocean and collision between the Lhasa and Qiangtang blocks probably formed a bivergent foreland thrust belt along the northern margin of the LHB (Kapp et al., 2003; Leier et 
al., 2007). This thrust belt may had functioned as a geographic barrier, further preventing the LHB from shedding sediment into the Qamdo basin.

\section{Bangong Arc (BGA) Signature (Sources to the S-SW of Qamdo Basin)}

Magmatism of BGA appears to have developed diachronously along the BangongNujiang suture zone (BNSZ) (e.g., Zhang et al., 2012; Guynn et al., 2013; Liu et al., 2015). In the vicinity of the Qamdo basin, BGA magmatic rocks that intruded the Tongka basement (Fig. 1) (He et al., 2011) yielded $~ 167$ Ma zircon U-Pb ages (Zhang et al., 1994). In contrast, westward in central Tibet BGA magmatism mainly occurred during 170-185 Ma (Guynn et al., 2006; 2012), and even further to the west Tibet it developed later at 160-175 Ma (Shi, 2007). However, recent studies of Early Cretaceous ( 130-100 Ma) ophiolites found in central Tibet (Zhang et al., 2012; Liu et al., 2015) suggest the Meso-Tethyan ocean may not have fully closed by Early Cretaceous time.

\section{Evidence for BGA Provenance}

The $165-190$ Ma zircon grains in the Middle-Upper Jurassic Upper Chaya Group (Figs. 7A; 8D) were most likely sourced from erosion of BGA extrusive rocks (Fig. 1B), as there are no other possible sources of Jurassic zircon near the Qamdo basin, even possible removal of source rocks from the immediate area by strike-slip fault movement is taken into consideration (Pan et al., 2004). The BGA source is also supported by an increase of volcanic lithic content from $<4 \%$ to $>20 \%$ in the Upper Chaya sandstones with increasing proximity to the BGA (Fig. 1B; Table DR1)

\section{INTERPRETATION OF PROVENANCE}


Provenance of the Upper Triassic Strata: Late Triassic Folding and Erosional Exhumation of the Yidun Terrane (YDT)

Sandstone modal data plotted on provenance discrimination diagrams indicate that Upper Triassic strata of the Qamdo basin were derived from craton block and quartzose recycled orogen source areas (Figs. 3A-C). Regional tectonic studies suggest that by the end of the Norian ( 204 Ma) in Late Triassic time, the Bayan Har, Songpan-Ganzi, and Yidun terranes had been deformed into a regional fold-thrust belt due to closure of the Paleo-Tethys to the north of the Qamdo basin (Roger et al., 2008; Weislogel, 2008; Gehrels et al., 2011; Burchfiel and Chen, 2013). We interpret that the Upper Triassic Qamdo deposits were most likely sourced from detritus derived from erosion of deformed EYDT sedimentary rocks to the north (Fig. 1B). This interpretation is consistent with the QpLvmLsm plot (Fig. 3C) which shows mainly collisional suture and fold-thrust belt origins for the Upper Triassic sandstone samples, and high similarities between detrital zircon age signatures of the Upper Triassic Qamdo strata and the Triassic Yidun Group (Figs. 5D-E). An alternative interpretation is that Qamdo basin Upper Triassic strata may represent a continuation of the Yidun Group deposystem in Late Triassic, however, depositional age constraints indicate that the Upper Triassic Qamdo strata are generally younger than Yidun Group deposits. The maximum depositional age inferred from the youngest 4 grains from the Bagang Group (Table DR2) yield a maximum depositional age of $218.4 \pm 5.0 \mathrm{Ma}(2 \sigma)$ (Dickinson and Gehrels, 2009). While the maximum depositional age of the underlying Jiapila Formation derived from the youngest single detrital zircon grain gives a maximum depositional age of $219 \pm 3.3 \mathrm{Ma}(2 \sigma)$ (Table DR2). Although maximum depositional age derived from the youngest single grain age is statically less robust than estimates made from multiple grains, study of Colorado Plateau sediments indicates the method can still yield reliable estimates of 
maximum depositional ages in $>90 \%$ cases (Dickinson and Gehrels, 2009). The inferred maximum depositional ages for the Bagang Group and Jiapila Formation are both consistent with Carnian (228-216 Ma; Jiapila Formation) and Norian-Rhaetian (216-200 Ma; Bagang Group) ages inferred from previous paleontological work (Du et al., 1997; Peng et al., 2005), and are generally younger than the minimum depositional age of ca. 230-220 Ma of the Yidun Group inferred from ages of dacitic intrusions (Wang et al., 2011), despite some overlap at 220 Ma for the Jiapila Formation.

We note that there was a phase of widespread carbonate deposition occurred during early Norian ( 215 Ma; Peng et al., 2005) which deposited 300 m thick Bolila Limestone on top of the Jiapila Formation, succeed by $~ 1500$ m thick marginal marine/deltaic deposition of the Bagang Group (Fig. 2). Whether the termination of carbonate deposition marks the beginning of inversion and erosion of the EYDT due to eastern Paleo-Tethyan (i.e., Ganzi-Liang ocean) closure, or just reflects a redirection of drainages into the Qamdo basin, however, is not clear.

Together, the combined evidence of sandstone provenance, depositional age and tectonic synthesis suggest that Upper Triassic deposits of the Qamdo basin were most likely derived from erosion of EYDT sedimentary rocks during the Late Triassic orogeny of northeastern Tibet (e.g., Roger et al., 2008; Weislogel, 2008).

Provenance of the Lower Jurassic Strata: Localized Exhumation along the Jinsha Suture and

\section{Development of Three Separate Depocenters}

At the beginning of Early Jurassic time, Qamdo depositional system shifted from marginal marine/deltaic deposition of the Upper Triassic Bagang Group to terrestrial/lacustrine deposition of the Jurassic Chaya Group. Similar to the Upper Triassic Qamdo samples, most of 
the Lower Jurassic Qamdo samples are derived from quartzose recycled orogen sources (Figs. 3D-E), as indicated by high quartz content and common presence of siliciclastic sedimentary lithics fragments (Fig. 4C). However, spatial variability of detrital zircon ages in the Lower Jurassic samples reveals development of at least three distinct depocenters in the Qamdo basin during Early Jurassic time. The southern depocenter samples contain abundant volcanic lithic fragments (i.e., LJ-3, LJ-8, LJ-9) (Fig. 3F; Table DR1) and detrital zircon ages at 230-245 Ma (Fig. 6B), suggesting local sediment influx from erosion of the JWA (Fig. 8A). The occurrence of abundant middle Paleoproterozoic (1870-1840 Ma) detrital zircon ages in the central depocenter samples (Fig. 6B) indicates erosion of Zhongza basement rocks. The presence of JWA and ZM signatures in Lower Jurassic samples suggests erosional exhumation along the Jinsha suture occurred by Early Jurassic time, probably related to development of the Zhongza thrust system and continued convergence along the Paleo-Tethyan margin (Jolivet et al., 2015; $\mathrm{Xu}$ et al, 2015). Sediments in the northern Qamdo depocenter mainly received sediments derived from recycled Upper Triassic Qamdo basin strata, as indicated by quartzose recycled provenance (Fig 3D-F), and high similarity of detrital zircon ages between the northern depocenter Lower Jurassic sample and Upper Triassic samples indicated from comparison of common age populations (i.e., 230-330, 400-500, 700-1200, 1700-1950, 2400-2600 Ma) (Table 1) and high Pvalues (>0.05) returned from K-S test for 2 out of 4 sample pairs (Table 2).

Our provenance interpretation suggests that during Early Jurassic time sediment routing system was more restricted, transporting detritus derived only from nearby sources (Fig. 10B). The inference is also broadly consistent with fine-grained alluvial and lacustrine deposition of the Lower Chaya Group (Fig. DR2C-F), indicating more stagnant basin hydrology during Early Jurassic. 


\section{Provenance of the Middle-Upper Jurassic Strata: Exhumation of the BGA and Internally- recycled Sources}

The Middle-Upper Jurassic strata were sourced primarily from erosion of uplifted Upper Triassic Qamdo strata and BGA volcanic rocks along the BNSZ. Spatial variability of detrital zircon ages in the Middle-Upper Jurassic samples still exist and indicates that at least three distinct depocenters that formed during Early Jurassic persisted untill Middle-Late Jurassic time (Figs. 10B-C). The samples from the northern and southern Qamdo basin have a quartzose recycled provenance (Figs. 3G-H) and are interpreted to sourced from recycled Upper Triassic strata as supported by high similarities of pre-Mesozoic detrital zircon ages between the Upper Triassic and Middle-Upper Jurassic Qamdo samples (Fig. 9), with K-S test of pre-Mesozoic ages yielded P-values $>0.05$ for 9 out of 12 sample pairs (Table 4 ). In contrast, samples from the central Qamdo basin show greater magmatic arc component as indicated by a high volcanic lithic content (Fig. 3I), suggesting significant sediment influx from magmatic arc source/sources. The presence of abundant Jurassic ages (190-165 Ma; 33\% of total grains) in the sample (i.e., MUJ-2) from central Qamdo depocenter (Fig. 7A) further suggest localized influx of volcaniclastic detritus derived from the BGA exposed to the west of central Qamdo basin (Fig. 1). It has been proposed that the Jurassic BGA magmatism was fueled by northward subduction of the MesoTethys beneath the Qiangtang block (Girardeau et al., 1984; Yin and Harrison; 2000; Kapp et al., 2007; Zhang et al., 2012; Liu et al., 2015), with subsequent collision between Lhasa and Qiangtang blocks likely causing erosional exhumation of the BGA to source Qamdo basin Middle-Upper Jurassic deposits. In comparison, Jurassic zircon grains (165-190 Ma) are rare in coeval samples from the northern and southern Qamdo depocenters (Fig. 7A), indicating the 
BGA was not a widespread source of sediments for the Qamdo basin. However, it is unclear that why exhumation of the BGA only occurred locally close to the central Qamdo basin during Middle-Late Jurassic time. Recent studies have suggested that collision between the Qiangtang and Lhasa blocks occurred highly diachronously along the BNSZ, with the proposed time of collision ranging from Middle Jurassic (Girardeau et al., 1984; Leeder et al., 1988; Guynn et al., 2006; Shi, 2007) to Early Cretaceous (Zhang et al., 2012; Liu et al., 2015). The diachronous nature of Lhasa-Qiangtang collision may responsible for the heterogeneous exhumation of the BGA along the BNSZ, which only exposed the arc to surface level in limited regions (e.g., Guynn et al., 2006; 2012).

\section{Provenance of the Cretaceous Xiangdui Formation: Reactivation of Exhumation of the JWA and Internally-recycled Sources}

The Cretaceous samples have mixed recycled orogen and magmatic arc provenance sandstone petrology signature (Fig. 3J-L), as indicated by high quartz content and common presence of volcanic lithic grains. High volcanic lithic content (Fig. 3L; Table DR1) and abundant $\sim 230-245$ Ma detrital zircon grains (Fig. 7B) most likely reflect sediment influx from the JWA located to the southeast of the Qamdo basin (Fig. 1). The interpretation is consistent with northwestward paleocurrent directions recorded in Cretaceous alluvial strata (Fig. 2). Another important sediment source came from the recycled Upper Triassic Qamdo strata, as indicated by high similarity of pre-Mesozoic zircon ages between the Cretaceous and Upper Triassic samples (Fig. 9) and K-S test which returned P-values >0.05 (range from 0.07 to 0.95 ) for 5 out of 8 sample pairs (Table 4). 
During Cretaceous, significant shrinkage of basin size (Fig. 1) accompanied by a major shift of sedimentary facies from fine-grained Jurassic lacustrine deposition (Fig. DR1D-F) to Cretaceous alluvial deposition characterized by coarse-grained sandstone and thick-bedded conglomerate layers (Fig. DR1H-I) signifies a major transition in regional tectonic setting of the Qamdo area. Localized uplift and exhumation of the JWA can be inferred from northwestward paleocurrent directions (Fig. 2), abundant granite clasts (Fig. DR1I), and presence of abundant 230-245 Ma detrital zircon ages in Cretaceous samples (Fig. 7B).

\section{TECTONIC CONTROL ON QAMDO BASIN MESOZOIC PROVENANCE EVOLUTION}

\section{Late Triassic Closure of the Eastern Paleo-Tethys}

Provenance data indicate Upper Triassic deposits of the Qamdo basin were sourced from erosion of the exhumed Yidun terrane as a result of the closure of the Paleo-Tethyan GanziLitang ocean and development of a widespread fold-thrust belt in northeastern Tibet during Late Triassic time (Fig. 10A; Roger et al., 2008; Weislogel, 2008; Gehrels et al., 2011; Burchfiel and Chen, 2013; Xu et al., 2015). Closure of the Paleo-Tethyan Ganzi-Liang ocean and subsequent collision between the Songpan-Ganzi and Yidun terranes generated orogen-perpendicular compression that propagated to the southeastern Tibet (Yang et al., 2014). The widespread Late Triassic fold-thrust belt (composed of the Bayan Har, Songpan-Ganzi, and Yidun terranes; Roger et al., 2008) not only provided sediments into the Qamdo basin, but may have also contributed detritus into the Sichuan (Luo et al., 2014) and even Ordos (Xie and Heller, 2013) basins.

Inside the Qamdo basin, marine shale and thin-bedded turbidite sandstone of the Jiapila Formation (Carnian in age) (Fig. DR1A) and the overlying Bolila Limestone (early Norian in 
age) (Fig. 2) reflect a long period of low clastic input into the Qamdo basin. The reduced clastic influx from the folded Yidun terrane suggests the locus of max subsidence during Carnian-early Norian time was probably closer to the fold belt and the Qamdo basin was probably located in a more distal part of the foreland basin. In contrast, $\sim 1500 \mathrm{~m}$ thick marginal marine/deltaic deposition of the Bagang Group (late Norian-Rhaetian in age) (Fig. DR1B) signifies a period of enhanced clastic input, which was probably resulted from southwestward fold-thrust belt growth related to the widespread Late Triassic orogensis in northeastern Tibet ( 220-200 Ma) (Roger et al., 2008; Weislogel, 2008; Burchfiel and Chen, 2013; Wang et al., 2014; Yang et al., 2014; Xu et al., 2015). Alternatively, the change of deposition settings in the Late Cretaceous Qamdo basin from black shale/carbonate platform to sandstone deltaic depositions could have also been associated with the onset of syn-collisional orogenesis in the Yidun terrane followed the closure of the Paleo-Tethyan Ganzi-Litang ocean, though a better constraint on the timing of Yidun orogenesis is needed to test this interpretation (e.g., Wang et al., 2014).

\section{Early Jurassic collisional tectonism of Eastern Paleo-Tethyan closure and Middle-Late Jurassic Closure of the Eastern Meso-Tethys}

Transition from Late Triassic marginal marine (e.g., Bagang Group) to Early Jurassic alluvial and lacustrine (e.g., Chaya Group) deposition (Fig. DR1A-D) signifies the Qamdo basin was overfilled by earliest Jurassic time. Growth of the Zhongza fold belt along the northeastern Qamdo margin continued during Early Jurassic, driven by compressional stress created by the continued collision between the Songpan-Ganzi and Yidun terranes (Jolivet et al., 2015; Xu et al., 2015). Significant spatial variations of detrital zircon ages (Figs. 6B, 7A) and sandstone detrital modes (Figs. 3D-I) in Jurassic samples reveal development of three distinct depocenters 
in the Qamdo basin during Jurassic time. During Early Jurassic, abundant 1840-1870 and 230245 Ma grains found in the central and southern depocenters, respectively, suggest erosion of the ZM, JWA and associated rocks along the northeastern margin of Qamdo basin (Fig. 10B). In contrast, sample from the northern depocenter lacks the JW or JWA zircon age signature, and has detrital zircon signature similar to the Upper Triassic Qamdo samples (Fig. 7B). The spatial variation of detrital zircon signatures in Lower Jurassic samples suggest during Early Jurassic time, sediment routing system was more restricted, only tapping sediments derived from nearby sources.

The occurrence of $\sim 165-190$ Ma zircon grains (Fig. 7A) and abundant volcanic lithic fragments (Fig. 3L) in Middle-Upper Jurassic strata suggest a change of drainage influx which started sourcing sediments from the BGA located to the southwest of Qamdo basin (Fig. 10C), although paleocurrent indicators are rare in lacustrine facies (Fig. DR1D-F). Erosion of the BGA was likely resulted from the collision between the Lhasa and Qiangtang blocks initiated in Middle Jurassic time (e.g., Girardeau et al., 1984; Yin and Harrison; 2000; Kapp et al., 2007; Zhang et al., 2012; Liu et al., 2015). During this period, the Qamdo basin accumulated 3,500 $\mathrm{m}$ thick of sediments that comprise about half of the total thickness of the Qamdo Mesozoic sequence (Fig. 2), reflecting an episode of enhanced basin subsidence. We suggest that the Middle-Late Jurassic subsidence of the Qamdo basin was probably related to crustal loading of the fold-thrust belt developed along the BNSZ, generated by the Lhasa-Qiangtang collision (e.g., Guynn et al., 2013). The interpretation is consistent with distribution of Middle-Late Jurassic sedimentation in the Qamdo basin which was concentrated in south half of the basin along the BNSZ (Fig. 1). The distribution of Middle-Upper Jurassic strata suggests location of max 
subsidence center was close to the BNSZ during Middle-Late Jurassic time, reflecting influence of orogenic crustal loading existed to the southwest of the basin (i.e., the BNSZ).

No Jurassic zircon grains have been found in the Lower Jurassic strata, as compared to abundant $190-180$ Ma grains (up to 30\%) found within the Middle-Upper Jurassic sediments (Fig. 8C-D). Onset of the northward subduction of the Meso-Tethyan ocean beneath the Qiangtang block by Early Jurassic time ( 190 Ma) is indicated by active BGA magmatism during Early Jurassic (e.g., Dewey et al., 1988; Yin and Harrison, 2000; Kapp et al., 2007; Zhang et al., 2012; Guynn et al., 2006, 2013; Zhang et al., 2014b; Liu et al., 2015). The lack of Jurassic zircons in the Lower Jurassic sedimentary record (Fig. 6B) suggests the BGA contributed no detritus into the Qamdo basin during Early Jurassic time, despite their close geographic proximity (Fig. 1B). It is possible that sediment transport direction during Early Jurassic was from northeast to southwest which prevented the BGA from sourcing the Qamdo basin, however, given the close proximity of the sampling sites of Lower Jurassic sandstones and the BGA (Fig. 1) and the low-energy deposition of Lower Jurassic lacustrine and paleosol deposits (Fig DR1C), the Lower Jurassic sediments should at least record a trace of BGA signal if the arc was actively developed on the southern margin of Qiangtang block (e.g., Guynn et al., 2013). Another possibility is that the Qamdo basin and the BGA may have originally been far away from each other during Early Jurassic time, and later been moved closer during Middle Jurassic by strike slip faulting, however, this is not likely given the lack of evidence for Mesozoic strike slip faulting in southeastern Tibet region (Yin and Harris, 2000).

Here, we propose that the missing of BGA signature in the Lower Jurassic Qamdo basin was probably resulted from opening of an Early Jurassic oceanic back-arc basin between the Tongka basement and the southeastern Qiangtang block (Fig. 10B) based on: 1) the occurrence 
of widespread Jurassic ophiolitic mélange to the west of Qamdo margin and ophiolite belt within the Tongka basement (Fig. 1); and 2) similar tectonic models suggested from the BGA that intruded the Amdo basement along BNSZ in central Tibet (Guynn et al., 2006; 2013).

Guynn et al. (2006) studied the Amdo granite gneiss basement exposed along the central BNSZ and suggest a short-lived Early Jurassic oceanic back-arc basin may have existed between the Amdo basement and Qiangtang block, possibly due to slab rollback during Meso-Tethyan subduction. Existence of the back-arc basin is further supported by ophiolitic fragments north of the Amdo basement (Pan et al., 2004), along with extensive Early-Middle Jurassic marine sedimentation in the southern Qiangtang block and BNSZ, which is lacking in the Lhasa block (Leeder et al., 1988; Yin et al., 1988; Schneider et al., 2003; Guynn et al., 2006).

In comparison, geologic data indicate that the Tongka orthogneiss basement exposed to the west of the Qamdo basin along the southern BNSZ may have a similar origin as the Amdo gneiss. The Tongka basement is bounded by an ophiolite belt to the southwest and Jurassic ophiolitic mélange deposits to the northeast (Fig. 1B; Pan et al., 2004), similar to the Amdo gneiss (Guynn et al., 2006; 2012). U-Pb crystalline ages of zircon from the Tongka orthogneiss range from 450 to $550 \mathrm{Ma}$ (He et al., 2011), identical to the Cambro-Ordovician (540-460 Ma) crystallization ages of the Amdo basement (Guynn et al., 2006; 2012). Meanwhile, both the Amdo and Tongka basements were intruded by extensive Jurassic igneous rocks related to the subduction of the Meso-Tethyan ocean. Therefore, the Amdo and Tongka basements may have once belonged to an integrated continental sliver oriented parallel to the BNSZ, which had rifted from the Qiangtang block during the opening of an Early Jurassic backarc basin on the western Qiangtang margin due to the Meso-Tethyan subduction. We speculate that now the continental fragment is largely 'missing' along the BNSZ because it was either buried by younger cover 
strata or subducted northward beneath the Qiangtang block (e.g., Guynn et al., 2006; 2012; 2013). Opening of an Early Jurassic back-arc basin between the Tongka basement and Qiangtang block could explain the lack of Jurassic-age zircons in the Lower Jurassic Qamdo strata, as the backarc basin would have functioned as a geological barrier, preventing the BGA-derived sediments from reaching the Qamdo basin (Fig. 10B). The Early Jurassic ophiolitic mélange deposits within the BNSZ may contain sediments derived from the Tonka basement and associated BGA, but the sediments were not transported further to the Qamdo basin.

Cessation of the Meso-Tethyan subduction and subsequent collision between the Lhasa and Qiangtang blocks during Middle to Late Jurassic time in our study area is marked by an ophiolite belt exposed to the west of the Tongka basement (Fig. 1B), representing the southward obduction of Meso-Tethyan oceanic crust onto the northern margin of the Lhasa block (e.g., Girardeau et al., 1984; Leeder et al., 1988; Zhou et al., 1997; Guynn et al., 2006; 2013). As a result, abundant Early-Middle Jurassic ( 165-190 Ma) BGA zircon grains were transported into the Qamdo basin during Middle-Late Jurassic time, recording erosion of the BGA-related rocks formed during convergence between the Lhasa and Qiangtang blocks (Fig. 10C). The presence of BGA zircon but lack of Tongka basement zircon (450-550 Ma) in Qamod samples suggest erosion of BGA extrusive igneous/volcanic rocks that covered up the Tonka basement. Postcollisional orogenesis associated with the collision between the Lhasa and Qiangtang blocks probably caused deformation and development of foreland fold-thrust belt along the southern margin of the of the Qamdo basin, causing subsidence and deposition of 3,500 m thickness Middle-Upper Jurassic lacustrine strata in the Qamdo basin (Fig. DR1D-G). 


\section{Cretaceous Intraplate Tectonism}

Cretaceous sediments in the Qamdo basin were derived from the JWA combined with recycled sources from Upper Triassic Qamdo strata interpreted to reflect an episode of uplift and exhumation of the JWA along the Jinsha suture. Across the Tibetan plateau, ample evidence of Cretaceous crustal deformation and shortening (e.g., Murphy et al., 1997; Kapp et al., 2005; 2007; DeCelles et al., 2007; Leier et al., 2007; Sun et al., 2015) and rapid rock cooling histories (e.g., Hetzel et al., 2011; Wilson and Fowler, 2011; Deng et al., 2012; Rohrmann et al., 2012; Zhang et al., 2012; Wang et al., 2014) have been documented, with associated mechanisms commonly attributed to continued shortening related to the collision between the Lhasa and Qiangtang blocks and/or the Neo-Tethyan flat-slab subduction beneath the Lhasa block causing crustal thickening. Recent thermochronology data from the Yidun and eastern Songpan-Ganzi terranes reveals an episode of extensive Late Jurassic-Early Cretaceous regional cooling that is interpreted to reflect widespread rock uplift in this area, resulting from compressional strain field related to Lhasa-Qiangtang collision (Tian et al., 2014). The JWA was probably been uplifted during this period of time and became a sediment source for the Cretaceous Qamdo basin. If that's the case, it is possible that the uplifted Yidun and even eastern Songpan-Ganzi terranes may had contributed sediments into the Qamdo basin, however, occurrence of thick-bedded conglomerates (Fig. DR1I) and a paucity of $~ 220$ Ma zircon grains in Cretaceous strata (Fig. 8E) suggest: 1) sediment transport distance was likely short during Cretaceous; and 2) EDYT was probably not a major source for the Cretaceous Qamdo basin as indicated by the missing of eastern Yidun arc signatures (Fig. 8A-E).

\section{IMPLICATION FOR MESOZOIC CLIMATE}


Provenance data of the Qamdo basin suggest that except for the Upper Triassic strata which were sourced primarily from the distant YDT, other Mesozoic sediments were mostly derived from the basin bounding ranges (e.g., ZM and BGA) combined with internally recycled sources. This source to sink pattern suggests that for $~ 100$ million years from Early Jurassic to Late Cretaceous time, the Qamdo basin was dominated by a persistent internal drainage system. However, why this internally-drained basin system persisted for such a long time without being defeated by drainage network expansion is unclear. Studies of modern internally drained basins in China (Sobel et al., 2003; Carroll et al., 2010) found that internally-drained basins are usually surrounded by active contractional orogenic belts and restricted to arid or semiarid regions. Fluvial incision modeling also suggests that high bounding range uplift rates, arid regional climatic conditions, and exposure of resistant lithologies of bounding ranges are the main causes of establishment of an internally drained basin system (e.g., Sobel et al., 2003).

We speculate that maintenance of the long-standing internal drainage system of the Jurassic to Cretaceous Qamdo basin was caused by active contractional tectonics related the subduction of Meso-Tethyan ocean and subsequent collision between the Qiangtang and Lhasa blocks (e.g., Zhou et al., 1997; Yin and Harrison, 2000; Kapp et al., 2005; 2007; Zhang et al., 2012; Liu et al., 2015); combined with arid tropical-subtropical greenhouse climatic conditions of southeastern Tibet under the Mesozoic greenhouse world (e.g., Takashima et al., 2006). This interpretation is supported by Jurassic and Cretaceous sedimentary records which show abundant desiccation features (Fig. DR1F) and calcic paleosols (Fig. DR1C; 1J) indicating arid to semiarid climate condition (e.g., Mack et al., 1993).

\section{CONCLUSIONS}


Sediment provenance study of the Mesozoic Qamdo basin revealed that the basin was sourced primarily from erosion of Triassic turbidite of the Yidun Group, metasedimentary rocks of the Zhongza massif, igneous rocks of the Jomda-Weixi arc and Bangong arc, and recycled Upper Triassic Qamdo strata. Upper Triassic sediments of the Qamdo basin were sourced primarily from the inverted Yidun Group as a result of the closure of the Paleo-Tethyan GanziLitang ocean and development of a widespread fold-thrust belt in northeastern Tibet during Late Triassic time (e.g., Roger et al., 2008). Three distinct depocenters developed in the Qamdo basin by the beginning of Early Jurassic time, as indicated by a spatial diversification of detrital zircon age signatures. The northern depocenter received detritus derived primarily from the recycled Upper Triassic Qamdo strata; whereas, the central depocenter has a mixed provenance of Zhongza massif metasedimentary rocks and recycled Upper Triassic Qamdo strata. The prominent $\sim 230-245 \mathrm{Ma}$ peak in the southern depocenter signifies sediment influx from the Jomda-Weixi arc. A lack of Jurassic age zircons in the Lower Jurassic sedimentary rocks is interpreted to reflect a temporal geographical segregation between the Bangong arc and the Qamdo basin due to the opening of a short-lived Early Jurassic oceanic backarc basin, which was probably related to slab rollback during Meso-Tethys subduction (Guynn et al., 2006; 2013).

The Middle-Upper Jurassic strata were sourced from recycled Upper Triassic Qamdo strata and exhumed Bangong arc plutons that intruded the Tongka basement. Abundant 165190 Ma zircon grains in the Middle-Upper Jurassic strata suggest exhumation and erosion of the Bangong arc related to the convergence between Lhasa and Qiangtang blocks during Mid-Late Jurassic time.

Cretaceous strata were mostly sourced from the Jomda-Weixi arc combined with sediment input from internally-recycled Qamdo strata. The cause of the reactivated exhumation 
of the Jomda-Weix arc was probably related to the northward underthrusting of the Lhasa terrane beneath the Qiangtang block during Early Cretaceous time (e.g., Kapp et al., 2003; 2005; Zhang et al., 2012; Tian et al., 2014; Liu et al., 2015).

The provenance data also reveal that the Qamdo basin was dominated by a long-standing internally drained basin system by Early Jurassic time as most Jurassic and Cretaceous sediments were derived from the basin bounding ranges and internally recycled sources. This internally drained basin system persisted for about 100 million years without being defeated by orogentraversing channels which most likely due to topographic drainage barriers created by active contractional tectonism and maintained by arid climate conditions in southeastern Tibet during middle to late Mesozoic time.

\section{ACKNOWLEDGMENTS}

This work was supported by the National Science Foundation under grants EAR-1119219 to Weislogel and EAR-1119266 to Robinson. We thank Arizona Laserchron Center personnel for assistance with laser ablation-inductively coupled plasma-mass spectrometry (LA-ICP-MS) analyses, as well as financial support provided by the National Science Foundation under grant EAR-1032156 for students travel to the Arizona LaserChron Center. The authors acknowledge Dr. Xiumian $\mathrm{Hu}$ and Gaoyuan Sun from the Nanjing University and Dr. Chunmiao Zheng from Peking University for help with field work and logistics. 


\section{REFERENCES CITED}

Barazangi, M., and Ni, J., 1982, Velocities and propagation characteristics of Pn and Sn beneath the Himalayan arc and Tibetan Plateau: possible evidence for underthrusting of Indian continental lithosphere beneath Tibet: Geology, v. 10, p. 179-185.

Burchfield, B.C., and Chen, Z.L., 2013, Tectonics of the southeastern Tibetan Plateau and its adjacent foreland: GSA Memoirs 210, Geological Society of America, 164 p.

Bureau of Geology and Mineral Resources of Sichuan Province (B.G.M.R.S.P.), 1991, Regional Geology of Sichuan Province: Geological Memoir 23: Beijing, Geological Publishing House, $707 \mathrm{p}$.

Carroll, A.R., Graham, S.A., and Smith, M.E., 2010, Walled sedimentary basins of China: Basin Research, v. 22, p. 17-32, doi:10.1111/j.1365-2117.2009.00458.x.

Carroll, A.R., Bohacs, K.M., 1999, Stratigraphic classification of Ancient Lakes: balancing tectonic and climatic controls: Geology, 27, 99-102.

Chang, C.F., 1997, Geology and Tectonics of Qinghai-Xizang Plateau: Science Press, Beijing, $153 \mathrm{p}$.

Chinese Geological Society (C.G.S.), 2004, Geological Map of the People's Republic of China Explanatory Notes: Beijing, SinoMap Press, 198 p.

Clark, M. K., and Royden, L. H., 2000, Topographic ooze: Building the eastern margin of Tibet by lower crustal flow: Geology, v. 28, no. 8, p. 703-706.

Currie, B. S., Rowley, D. B., and Tabor, N. J., 2005, Middle Miocene paleoaltimetry of southern Tibet: implications for the role of mantle thickening and delamination in the Himalayan orogen: Geology, v. 33, no. 3, p. 181-184. 
DeCelles, P.G., Kapp, P., Ding, L., and Gehrels, G.E., 2007, Late Cretaceous to mid-Tertiary basin evolution in the central Tibetan Plateau: Changing environments in response to tectonic partitioning, aridifi cation, and regional elevation gain: Geological Society of America Bulletin, v. 119, p. 654-680, doi: 10 .1130/B26074 .1.

DeGraaff-Surpless, K., Graham, S.A., Wooden, J.L., and McWilliams, M.O., 2002, Detrital zircon provenance analysis of the Great Valley Group, California: evolution of an arc forearc system: Geological Society of America Bulletin, v. 114, no. 12, p. 1564-1580, doi: 10.1130/0016-7606(2002)114<1564:DZPAOT>2.0.CO;2.

Deng, B., Liu, S.G., Li, Z.W., Cao, J.X., Sun,W., 2012. Late Cretaceous tectonic change of the Eastern Margin of Tibetan Plateau: results from multi-system thermochronology. Journal of the Geological Society of India 80, 241-254.

Dewey, J.F., Shackleton, R.M., Chang, C., and Yiyin, S., 1988, The tectonic evolution of the Tibetan Plateau: Philosophical Transactions of the Royal Society of London, series A, v. 327, p. 379-413.

Dickinson, W.R., 1985, Interpreting provenance relations from detrital modes of sandstones, in Zuffa, G.G., ed., Provenance of Arenites: Boston, D. Reidel Publishing Company, p. 333361.

Dickinson, W.R., and Gehrels, G.E., 2009, Use of U-Pb ages of detrital zircons to infer maximum depositional ages of strata: A test against a Colorado Plateau Mesozoic database: Earth and Planetary Science Letters, v. 288, p. 115-125, doi:10.1016/j. epsl. 2009.09.013.

Du, D., Li, J., and Li, X., 1997, Sedimentary evolution and palaeogeography of the Qamdo block in Xizang: Sedimentary Facies and Palaeogeography, v 17, no. 4, p. 1-17. 
England, P., and Searle, M., 1986, The Cretaceous - Tertiary deformation of the Lhasa block and its implications for crustal thickening in Tibet: Tectonics, v. 5, no. 1, p. 1-14.

Folk, R. L., 1974, The petrology of sedimentary rocks: Hemphill, Austin, Texas 182 p.

Garcia-Castellanos, D. , 2006, Long-term evolution of Tectonic Lakes: climatic controls on the development of internally drained basins. In: Tectonics, Climate, and Landscape Evolution (Ed. by S.D.Willet, N. Hovius, M.T. Brandon \& D. Fisher), Penrose Conf. Ser., Geol. Soc. Am. 283-294.

Gehrels, G.E., Valencia, V., Ruiz, J., 2008, Enhanced precision, accuracy, efficiency, and spatial resolution of $\mathrm{U}-\mathrm{Pb}$ ages by laser ablation-multicollector-inductively coupled plasma-mass spectrometry: Geochemistry, Geophysics, Geosystems, v. 9, Q03017, doi:10.1029/2007GC001805.

Gehrels, G.E., 2010, K-S Test: An Excel macro program for doing statistic K-S comparison between age distributions: http://laserchron.org/laserchron/home/K-S Test.xls (accessed December 2012).

Gehrels, G.E., Kapp, P., DeCelles, P., Pullen, A., Blakey, R., Weislogel, A., Ding, L., Guynn, J., Martin, A., McQuarrie, N., Yin, A., 2011, Detrital zircon geochronology of pre-Tertiary strata in the Tibetan-Himalayan orogen: Tectonics, v. 30, TC5016, 27 p. doi:10.1029/2011TC002868

Girardeau, J., Marcoux, J., Allègre, C.J., Bassoullet, J.P., Youking, T., Xuchang, X., Yougong, Z., and Xibin, W., 1984, Tectonic environment and geodynamic significance of the NeoCimmerian Donqiao ophiolite, Bangong-Nujiang suture zone, Tibet: Nature, v. 307, p. 2731. 
Gradstein, F.M., Ogg, J.G., Smith, A.G., Bleeker, W., and Lourens, L.J., 2004, A new geologic time scale, with special reference to Precambrian and Neogene: Episodes, v. 27, no. 2, p. $83-100$.

Guynn, J.H., Kapp, K., Pullen, A., Heizler, M., Gehrels, G., and Ding, L., 2006, Tibetan basement rocks near Amdo reveal "missing" Mesozoic tectonism along the Bangong suture, central Tibet: Geology, v. 34, p. 505-508, doi: 10.1130/G22453.1.

Guynn, J., and Gehrels, G.E., 2010, Comparison of detrital zircon age distributions using the K-S test: http://laserchron.org/laserchron/home/K-S Test Instructions.pdf (accessed December 2012).

Guynn, J., Kapp, P., Gehrels, G.E., and Ding, L., 2012, U-Pb geochronology of basement rocks in central Tibet and paleogeographic implications: Journal of Asian Earth Sciences, v. 43, p. 23-50, doi:10.1016/j.jseaes.2011.09.003.

Guynn, J., Tropper, P., Kapp, P., Gehrels, G.E., 2013. Metamorphism of the Amdo metamorphic complex, Tibet: implications for the Jurassic tectonic evolution of the Bangong suture zone. Journal of Metamorphic Geology 31, 705-727.

Hearn, P., Jr., Hare, T., Schruben, P., Sheriff, D., LaMar, C., and Tsushima, P., 2001, Global GIS Database: Digital Atlas of South Asia: U.S. Geological Survey Digital Data Series DDS-62C.

Hetzel, R., Dunkl, I., Haider, V., Strobl, M., von Eynatten, H., Ding, L., and Frei, D., 2011, Peneplain formation in southern Tibet predates the India-Asia collision and plateau uplift: Geology, v. 39, p. 983-986, doi: 10 .1130/G32069.1 .

Holt, W.E., and Wallace, T.C., 1990, Crustal thickness and upper mantle velocities in the Tibetan plateau region from the inversion of regional Pnlwaveforms: Evidence for a thick 
upper mantle lid beneath southern Tibet: Journal of Geophysical Research, v. 95, p. 499525 .

Hou, Z.Q., 1993, Tectono-magmatic evolution of the Yidun island-arc and geodynamic setting of Kuroko-type sulfide deposits in Sanjiang region, SW China: Resource Geology Special Issue 17, p. 336-350.

Ingersoll, R.V., Bullard, T.P., Ford, R.L., Grimm, P., Pickle, L.D., and Sares, S.W., 1984, The effect of grain size on detrital modes: A test of the Gazzi-Dickinson point-counting method: Sedimentary Petrology, v. 54, p. 103-116.

Ingersoll, R.V., Dickinson, W.R., and Graham, S.A., 2003, Remnant-ocean submarine fans; largest sedimentary systems on Earth, in Chan, M.A., and Archer, A.W., eds., Extreme depositional environments: Mega end members in geologic time: Geological Society of America Special Paper 370, p. 191-208.

Jackson, T.W., Robinson, D., Weislogel, A., Jian, X., Shang, F., 2014, Mesozoic Deformation Recorded in Sedimentary Basin on top of the Northern Yidun Arc, Eastern Tibetan Plateau: Geological Society of America Abstracts with Programs. Vol. 46, No. 6, p.791

Jian, X., Guan, P., Zhang, D-W., Zhang, W., Feng, F., Liu, R-J., Lin, S-D., 2013, Provenance of Tertiary sandstone in the northern Qaidam basin, northeastern Tibetan Plateau: Integration of framework petrography, heavy mineral analysis and mineral chemistry. Sedimentary Geology, v. 290, p. 109-125, doi: 10.1016/j.sedgeo.2013.03.010.

Jolivet, M., Roger, F., Xu, Z.Q., Paquette, J.L., and Cao, H., 2015, Mesozoic-Cenozoic evolution of the Danba dome (Songpan Garzê, east Tibet) as inferred from LA-ICPMS U-Pb and fission-track data: Journal of Asian Earth Sciences, v. 102, p. 180-204, doi: 10.1016 /j .jseaes .2015.02.009. 
Kapp, P., Yin, A., Manning, C.E., Murphy, M., Harrison, T.M., Spurlin, M., Ding, L., Deng, X.G., and Wu, C.M., 2000, Blueschist-bearing metamorphic core complexes in the Qiangtang block reveal deep crustal structure of northern Tibet: Geology, v. 28, p. 19-22. Kapp, P., Murphy, M.A., Yin, A., Harrison, T.M., Ding, L., and Guo, J., 2003, Mesozoic and Cenozoic tectonic evolution of the Shiquanhe area of western Tibet: Tectonics, v. 22, p. 1029, doi: 10.1029/2001TC001332.

Kapp, P., Yin, A., Harrison, T.M., and Ding, L., 2005, Cretaceous-Tertiary shortening, basin development, and volcanism in central Tibet: Geological Society of America Bulletin, v. 117, p. 865-878, doi: 10.1130/B25595.1.

Kapp, P., DeCelles, P.G., Gehrels, G.E., Heizler, M., and Ding, L., 2007, Geological records of the Lhasa-Qiangtang and Indo-Asian collisions in the Nima area of central Tibet: Geological Society of America Bulletin, v. 119, p. 917-933, doi:10.1130/B26033.1.

Kind, R., Yuan, X., Saul, J., Nelson, D., Sobolev, S.V., Mechie, J., Zhao,W., Kosarev, G., Ni, J., Achauer, U., and Jiang, M., 2002, Seismic images of crust and upper mantle beneath Tibet: evidence for Eurasian plate subduction: Science, v. 298, p. 1219-1221.

Kumar, P., Yuan, X., Kind, R., and Ni, J., 2006, Imaging the colliding Indian and Asian lithospheric plates beneath Tibet: Journal of Geophysical Research, v. 111, doi:10.1029/2005JB003930.

Leeder, M.R., Smith, A.B., and Yin, J., 1988, Sedimentology, palaeoecology and palaeoenvironmental evolution of the 1985 Lhasa to Golmud Geotraverse: Royal Society of London Philosophical Transaction, series A, v. 327, p. 107-143, doi:10.1098/rsta.1988.0123. 
Leier, A. L., P. Kapp, G. E. Gehrels, and P. G. DeCelles, 2007, Detrital zircon geochronology of Carboniferous-Cretaceous strata in the Lhasa terrane, Southern Tibet: Basin Research, v. 19, p. 361-378, doi:10.1111/j.1365-2117.2007.00330.x.

Li, Z.X., Li, X.H., Kinny, P.D., Wang, J., Zhang, S., and Zhou, H., 2003, Geochronology of Neoproterozoic syn-rift magmatism in the Yangtze craton, South China, and correlations with other continents: Evidence for a mantle superplume that broke up Rodinia: Precambrian Research, v. 122, p. 85-109, doi:10.1016/S0301-9268(02)00208-5.

Liu, D.L., Shi, R.D., Ding, L., Huang, Q.S., Zhang, X.R., Yue, Y.H., Zhang, L.Y., 2015. Zircon $\mathrm{U}-\mathrm{Pb}$ age and $\mathrm{Hf}$ isotopic compositions of Mesozoic granitoids in southern Qiangtang, Tibet: implications for the subduction of the Bangong-Nujiang Tethyan Ocean. Gondwana Research. http://dx.doi.org/10.1016/j.gr.2015.04.007.

Ludwig, K., 2008, Isoplot 3.6: Berkeley Geochronology Center Special Publication 4, 77 p. Luo, L., Qi, J.F., Zhang, M.Z., Wang, K., Han, Y.Z., 2014, Detrital zircon U-Pb ages of Late Triassic-Late Jurassic deposits in the western and northern Sichuan Basin margin: constraints on the foreland basin provenance and tectonic implications: Int J Earth Sci (Geol Rundsch) v. 103 p.1553-1568, DOI 10.1007/s00531-014-1032-7

Mack, G.H., James,W.C., Monger, H.C., 1993, Classification of plaeosols: Geol. Soc. Am. Bull. $105,129-136$.

Metcalfe, I., 1988, Origin and assembly of Southeast Asian continental terranes: Gondwana and Tethys, edited by M. G. Audley-Charles and A. Hallam, Geological. Society Special Publication, v. 37, p. 101-118.

Metcalfe, I., 2009, Late Palaeozoic and Mesozoic tectonic and palaeogeographical evolution of SE Asia: Geological Society, London, Special Publications 315, pp. 7-23. 
Meng, Q., and Zhang, G., 2000, Geologic framework and tectonic evolution of the Qinling orogen, central China: Tectonophysics, v. 323, no. 3-4, p. 183-196, doi:10.1016/S00401951(00)00106-2.

Mo, X.X., 1993, Sanjiang Tethyan volcanism and related mineralization: Geological Memoirs of PRC Ministry of Geology and Mineral Resources, Series 3, 20, Geological Publishing House, Beijing, 267 p.

Molnar, P., and Tapponnier, P., 1975, Cenozoic tectonics of Asia: effects of a continental Collision: Science, v. 189, p. 419-426.

Molnar, P., England, P., and Martinod, J., 1993, Mantle dynamics, uplift of the Tibetan Plateau, and the Indian monsoon: Review of Geophysics, v. 31, p. 357-396.

Nelson, K.D., and INDEPTH seismic team, 1996, Partially molten middle crust beneath southern Tibet: synthesis of project INDEPTH results: Science, v. 274, p. 1684-1688.

Owens, T.J., and Zandt, G., 1997, Implications of crustal property variations for models of Tibetan plateau evolution: Nature, v. 387, p. 37-43.

Pan, G.T., Ding, J., Yao, D.S., and Wang, L.Q., 2004, Geological map of Qinghai-Xiang (Tibet) Plateau and adjacent areas: Chengdu, Chengdu Institute of Geology and Mineral Resources, China Geological Survey, scale 1:1,500,000, 6 sheets.

Peng, Yongmin, Liu, Jiaoduo, Luo, Jianning, 2005, Triassic sequence stratigraphy and evolution of sedimentary basin in Qamdo area: Geological publishing house: Beijing, $82 \mathrm{p}$.

Peng, T.P., Zhao, G.C., Fan, W.M., Peng, B.X., and Mao, Y.S., 2014, Zircon geochronology and Hf isotopes of Mesozoic intrusive rocks from the Yidun terrane, Eastern Tibetan Plateau: Petrogenesis and their bearings with $\mathrm{Cu}$ mineralization: Journal of Asian Earth Sciences, v. 80, p. 18-33, doi: 10.1016/j.jseaes.2013.10.028. 
Potter, P. E., and Pettijohn, F. J., 2012, Paleocurrents and basin analysis, Springer Science \& Business Media.

Powell, C.McA., 1986, Continental underplating model for the rise of the Tibetan Plateau: Earth and Planetary Science Letter, v. 81, p. 79-94.

Pullen, A., Kapp, P., Gehrels, G.E., Ding, L., and Zhang, Q.H., 2010, Metamorphic rocks in central Tibet: Lateral variations and implications for crustal structure: Geological Society of America Bulletin, v. 123, p. 585-600, doi:10.1130/B30154.1.

Qiu, Y.M., Shan, G., McNaughton, N.J., Groves, D.I., and Ling, W., 2000, First evidence of $>3.2$ Ga continental crust in the Yangtze craton of South China and its implications for Archean crustal evolution and Phanerozoic tectonics: Geology, v. 28, no. 1, p. 11-14, doi:10.1130/0091-7613(2000)028<0011:FEOGCC>2.0.CO;2.

Raphine, R., Tilmann, F.,West, M., Ni, J., Rodgers, A., 2003, Crustal structure of northern and southern Tibet from surface wave dispersion analysis: journal Of Geophysics Research, v. 108 (B2), p. 2120, doi:10.1029/2001JB000445.

Reid, A.J., Wilson, C.J.L., and Liu, S., 2005, Structural evidence for the Permo-Triassic tectonic evolution of the Yidun arc, eastern Tibetan Plateau: Journal of Structural Geology, v. 27, no. 1, p. 119-137, doi:10.1016/j.jsg.2004.06.011.

Reid, A., Wilson, C.J.L., Shun, L., Pearson, N., Belousova, E., 2007, Mesozoic plutons of the Yidun Arc, SW China: U/Pb geochronology and Hf isotopic signature: Ore Geology Reviews 31, p. 88-106, doi:10.1016/j.oregeorev.2004.11.003.

Roger, F., Jolivet, M.\&Malavieille, J. 2008. Tectonic Evolution of the Triassic Fold Belts of Tibet. Comptes Rendus Geoscience, Acade’́mie des Sciences, Paris, 340, 180-189. 
Rohrmann, A., Kapp, P., Carrapa, B., Reiners, P.W., Guynn, J., Ding, L., and Heizler, M., 2012, Thermochronologic evidence for plateau formation in central Tibet by 45 Ma: Geology, v. 40, p. 187-190, doi: $10.1130 / \mathrm{G} 32530.1$.

Royden, L., Burchfi el, B.C., and Van der Hilst, R., 2008, The geological evolution of the Tibetan Plateau: Science, v. 321, no. 5892, p. 1054-1058, doi: 10.1126/ science.1155371.

Schneider, W., Mattern, F., Wang, P., and Li, C., 2003, Tectonic and sedimentary basin evolution of the eastern Bangong-Nujiang zone (Tibet): A Reading cycle: Geologische Rundschau, v. 92, p. 228-254.

Shi, R., 2007, SHRIMP dating of the Bangong Lake SSZ-type ophiolite: Constraints on the closure time of ocean in the Bangong Lake-Nujiang River, northwestern Tibet: Chinese Science Bulletin, v. 52, p. 936-941.

Sobel, E.R., Hilley, G.E., and Strecker, M.R., 2003, Formation of internally drained contractional basins by aridity-limited bedrock incision: Journal of Geophysical Research, v. 108, p. 2344, doi: 10.1029/2002JB001883.

Song, X.Y., Zhou, M.F., Cao, Z.M., Robinson, P.T., 2004, Late permian rifting of the South China Craton caused by the Emeishan mantle plume?: Journal of the Geological Society, v. 161, no. 5, p. 773-781.

Stacey, J.S., and Kramers, J.D., 1975, Approximation of terrestrial lead isotope evolution by a two stage model: Earth and Planetary Science Letters, v. 26, p. 207-221.

Studnicki-Gizbert, C., Burchfiel, B., Li, Z., and Chen, Z., 2008, Early Tertiary Gonjo basin, eastern Tibet: Sedimentary and structural record of the early history of India-Asia collision: Geosphere, v. 4, no. 4, p. 713-735. 
Sun, G.Y., Hu, X.M., Sinclair, D.H., BouDagher-Fadel, K.M., and Wang, J.G., 2015, Late Cretaceous evolution of the Coqen Basin (Lhasa terrane) and implications for early topographic growth on the Tibetan Plateau, Geological Society of America Bulletin, doi: 10.1130/B31137.1

Takashima, R., Nishi, H., Huber, B. T., and Leckie, R. M., 2006, Greenhouse: Oceanography, v. 19, no. 4, p. 64.

Tao, Y., Bi, X.W., Li, C.S., Hu, R.Z., Li, Y.B., Liao, M.Y., 2014, Geochronology, petrogenesis and tectonic significance of the Jitang granitic pluton in eastern Tibet, SW China: Lithos,v. 184-187, p. 314-323, doi: 10.1016/j.lithos.2013.10.031.

Tapponnier, P., Xu, Z., Roger, F., Meyer, B., Arnaud, N., Wittlinger, G., and Yang, J., 2001, Oblique stepwise rise and growth of the Tibet Plateau: Science, v. 294, p. 1671-1677.

Tian, Y., Kohn, B.P., Hu, Sh., Gleadow, A.J.W., 2014, Postorogenic rigid behavior of the eastern Songpan-Ganze terrane: insights from low-temperature thermochronology and implications for intracontinental deformation in central Asia. Geochem. Geophys. Geosyst. 15, 453-474. Van der Plas, L., and Tobi, A.C., 1965, A chart for judging the reliability of point counting results: American Journal of Science, v. 263, p. 87-90, doi: 10 .2475 /ajs .263.1 .87 .

Vermeesch, P., 2004, How many grains are needed for a provenance study?: Earth and Planetary Science Letters, v. 224, no. 3-4, p. 441-451, doi: 10.1016/j.eps1.2004.05.037.

Vermeesch, P., 2012, On the visualisation of detrital age distributions: Chemical Geology, v. 312-313, p. 190-194.

Wang, Y.B., Han, J., Zeng, P.S.,Wang, D.H., Yin, G.H., Li,W.C., 2010, U-Pb dating and Hf isotopic characteristics of zircons from granodiorite in Yangla copper deposit, Denqin 
County, Yunnan, southwest China: Acta Petrologica Sinica v. 26, p. 1833-1844 (in Chinese with English abstract).

Wang, X., Metcalfe, I., Jian, P., He, L., and Wang, C., 2000, The Jinshajiang-Ailaoshan suture zone, China; tectonostratigraphy, age and evolution: Journal of Asian Earth Sciences, v. 18, no. 6, p. 675-690, doi: 10.1016/ S1367-9120(00)00039-0.

Wang, B.Q., Zhou, M.F., Li, J.W., Yan, D.P., 2011. Late Triassic porphyritic intrusions andassociated volcanic rocks from the Shangri-La region, Yidun terrane, Eastern TibetanPlateau: Adakitic magmatism and porphyry copper mineralization. Lithos 127,2438.

Wang, B.Q., Zhou, M.F., Chen, W.T., Gao, J.F., 2012, Petrogenesis and tectonic implications of the Triassic volcanic rocks in the northern Yidun Terrane, Eastern Tibet: Lithos, v.175-176, p. 285-301, doi:10.1016/j.lithos.2013.05.013.

Wang, B.Q., Zhou, M.F., Chen, W.T., Gao, J.F., and Yan, D.P., 2013, Constraints of detrital zircon $\mathrm{U}-\mathrm{Pb}$ ages and $\mathrm{Hf}$ isotopes on the provenance of the Triassic Yidun Group and tectonic evolution of the Yidun Terrane, Eastern Tibet: Sedimentary Geology, v. 289, p. 7498, doi: 10.1016/j.sedgeo.2013.02.005.

Wang, X.S., Hu, R.Z., Bi, X.W., Leng, C.B., Pan, L.C., Zhu, J.J., Chen, Y.W., 2014a, Petrogenesis of Late Cretaceous I-type granites in the southern Yidun Terrane: New constraints on the Late Mesozoic tectonic evolution of the eastern Tibetan Plateau, Lithos, Volumes 208-209, November 2014, Pages 202-219, ISSN 0024-4937, http://dx.doi.org/10.1016/j.lithos.2014.08.016.

Wang, B.D.,Wang, L.Q., Chen, J.L., Yin, F.G., Wang, D.B., Zhang, W.P., Chen, L.K., Liu, H., 2014b. Triassic three-stage collision in the Paleo-Tethys: constraints from magmatism in the 
Jiangda-Deqen-Weixi continental margin arc, SW China. Gondwana Research. http://dx.doi.org/10.1016/j.gr.2013.07.023

Weislogel, A.L., 2008, The Songpan-Ganzi complex: Record of basin initiation, evolution and collapse for the northeastern-most Tethys: Tectonophysics, v. 451, p. 331-345, doi: 10.1016/j.tecto.2007.11.053.

Weislogel, A.L., Graham, S.A., Chang, E.Z., Wooden, J.L., and Gehrels, G.E., 2010, Collisional orogenesis and spatial distribution of erosional exhumation: detrital zircon provenance and depocenter discrimination of the Middle-Late Triassic Songpan-Ganzi complex, central China: Geological Society of America Bulletin, v. 122; no. 11-12; p. 2041-2062; doi: 10.1130/B26606.1

Wilson, C.J.L., Fowler, A.P., 2011. Denudational response to surface uplift in east Tibet: evidence from apatite fission-track thermochronology. Geol. Soc. Am. Bull. 123 (9/10), 1966-1987.

Wu, G.J., Xiao, X.C., and Li, T.D., 1993, Lithospheric structure and evolution of the Tibetan Plateau: theYadong-Golmud Geoscience transect: Tectonophysics, v. 219, p. 213-221.

Xiao, L., He, Q., Pirajno, F., Ni, P., Du, J.X., Wei, Q.R., 2008, Possible correlation between a mantle plume and the evolution of Paleo-Tethys Jinshajiang Ocean: Evidence from a volcanic rifted margin in the Xiaru-Tuoding area, Yunnan, SW China: Lithos, v. 100, i. 1-4, p. 112-126.

Xie, X. Y., and Heller, P. L., 2013, U-Pb detrital zircon geochronology and its implications: the early Late Triassic Yanchang Formation, south Ordos basin, China: Journal of Asian Earth Sciences, v. 64, p. 86-98, http://dx.doi.org/10.1016/j.jseaes.2012.11.045 
Xu, Z.Q., Dilek, Y., Cao, H., Yang, J.S., Robinson, P., Ma, C.Q., Li, H.Q., Jolivet, M., Roger, F., Chen, X.J., 2015, Paleo-Tethyan evolution of Tibet as recorded in the East Cimmerides and West Cathaysides: Journal of Asian Earth Sciences, v. 105, n. 1 , p. 320-337, ISSN 13679120, http://dx.doi.org/10.1016/j.jseaes.2015.01.021.

Yang, X.A., Liu, J.J., Han, S.Y., Zhang, H.Y., Luo, C.,Wang, H., Chen, S.Y., 2011, U-Pb dating of zircon from granodiorite, Re-Os dating of molybdenite from the ore body and their geological significances in Yangla copper deposit, Yunnan: Acta Petrologica Sinica v. 27, p. 2567-2576 (in Chinese with English abstract).

Yang, T.N., Ding, Y., Zhang, H.R., Fan, J.W., Liang, M.J., Wang, X.H., 2014, Two-phase subducation and subsequent collision defines the Paleotethyan tectonics of the southeastern Tibetan Plateau: evidence from zircon U-Pb dating, geochemistry, and structural geology of the Sanjiang orogenic belt, southwest China: Geol. Soc. Am. Bull. v.126, n.1654-1682.

Yin, J., Xu, J., Liu, C., and Li, H., 1988, The Tibetan plateau: Regional stratigraphic context and previous work: Philosophical Transactions of the Royal Society of London, Series A, v. 327, p. 5-52.

Yin, A., and Harrison, T.M., 2000, Geologic evolution of the Himalayan-Tibetan orogen: Annual Review of Earth and Planetary Sciences, v. 28, p. 211-280, doi: 10.1146/annurev.earth.28.1.211.

Zhang, D.K., Li, Q.X., Luo, K.Y., Luo, J., 1994, Geological report and map of the Basu region (1: 200,000). Geological Survey of Xizang Province, China, 332 P.

Zhang, K.J., 2001, Blueschist-bearing metamorphic core complexes in the Qiangtang block reveal deep crustal structure of northern Tibet: Comment: Geology, v. 29, no. 90, doi:10.1130/0091-7613(2001)029<0090:BBMCCI>2.0.CO;2. 
Zhang, S.B., Zheng, Y.F., Wu, Y.B., Zhao, Z.F., Gao, S., and Wu, F.Y., 2006, Zircon isotope evidence for $\geq 3.5 \mathrm{Ga}$ continental crust in the Yangtze craton of China: Precambrian Research, v. 146, p. 16-34, doi: 10.1016/j.precamres.2006.01.002.

Zhang, K.J., Zhang, Y.X., Tang, X.C., and Xia, B., 2012, Late Mesozoic tectonic evolution and growth of the Tibetan plateau prior to the Indo-Asian collision: Earth-Science Reviews, v.114, no.3-4, p. 236-249, doi:10.1016/j.earscirev.2012.06.001.

Zhang, X.R., Shi, R.D., Huang, Q.S., Liu, D.L., Gong, X.H., Chen, S.S.,Wu, K., Yi, G.D., Sun, Y.L., Ding, L., 2014a. Early Jurassic high-pressure metamorphism of the Amdo terrane, Tibet: constraints from zircon U-Pb geochronology of mafic granulites. Gondwana Research 26, 975-985.

Zhang, L.-Y., Ding, L., Pullen, A., Xu, Q., Liu, D.-L., Cai, F.-L., Yue, Y.-H., Lai, Q.-Z., Shi, R.D., Ducea, M.N., Kapp, P., Chapman, A., 2014b. Age and geochemistry of western HohXil-Songpan-Ganzi granitoids, northern Tibet: implications for the Mesozoic closure of the Paleo-Tethys ocean. Lithos 190-191, 328-348.

Zhou, M.F., Malpas, J., Robinson, P.T., and Reynolds, P.H., 1997, The dynamothermal aureole of the Donqiao ophiolite (northern Tibet): Canadian Journal of Earth Sciences, v. 34, p. 5965. 


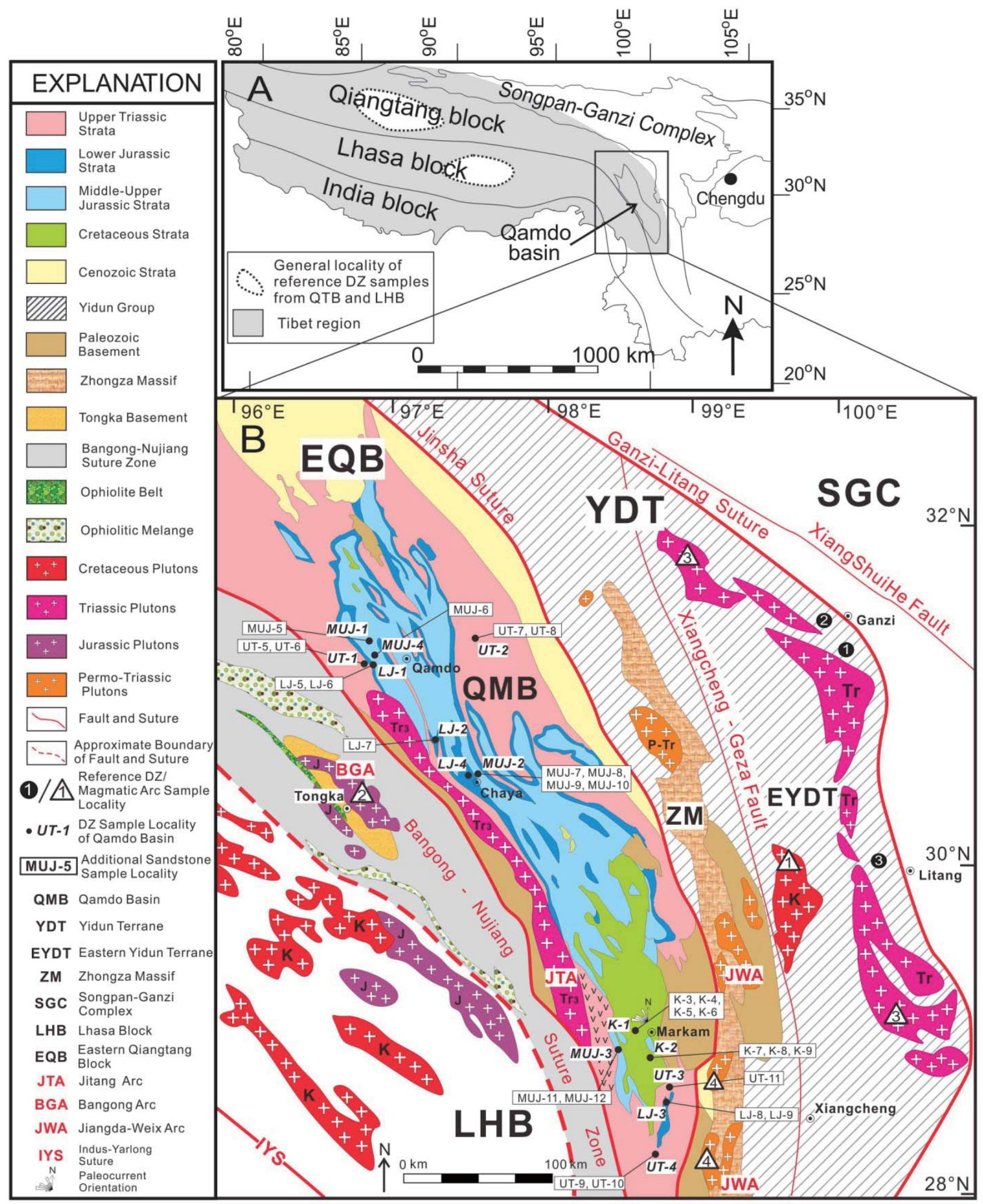


Figure 1. (A) Sketch tectonic map of Tibet, western China showing location of the Qamdo basin. Black box delineates extent of the study area and adjacent geological units in southeastern Tibet (after Meng and Zhang, 2000; C.G.S., 2004; Weislogel et al., 2010). General localities of reference detrital zircon samples from the Qiangtang and Lhasa blocks are shown in dashed areas. (B) Simplified geological map of Qamdo region showing major tectonic units and distribution of Mesozoic rocks of the Qamdo basin (adapted from Pan et al., 2004). Locations of reference detrital zircon samples (marked by white number in black cycle): 1 - 13UTSG-1; 2 - 13UTSG2; 3 - 13UTSG-427. Locations of reference magmatic arc zircon samples (marked by black number in triangle): 1 - Cretaceous pluton of the eastern Yidun terrane; 2 - Bangong arc; 3 Triassic plutons of the eastern Yidun terrane; 4 - Jomda-Weixi arc. 


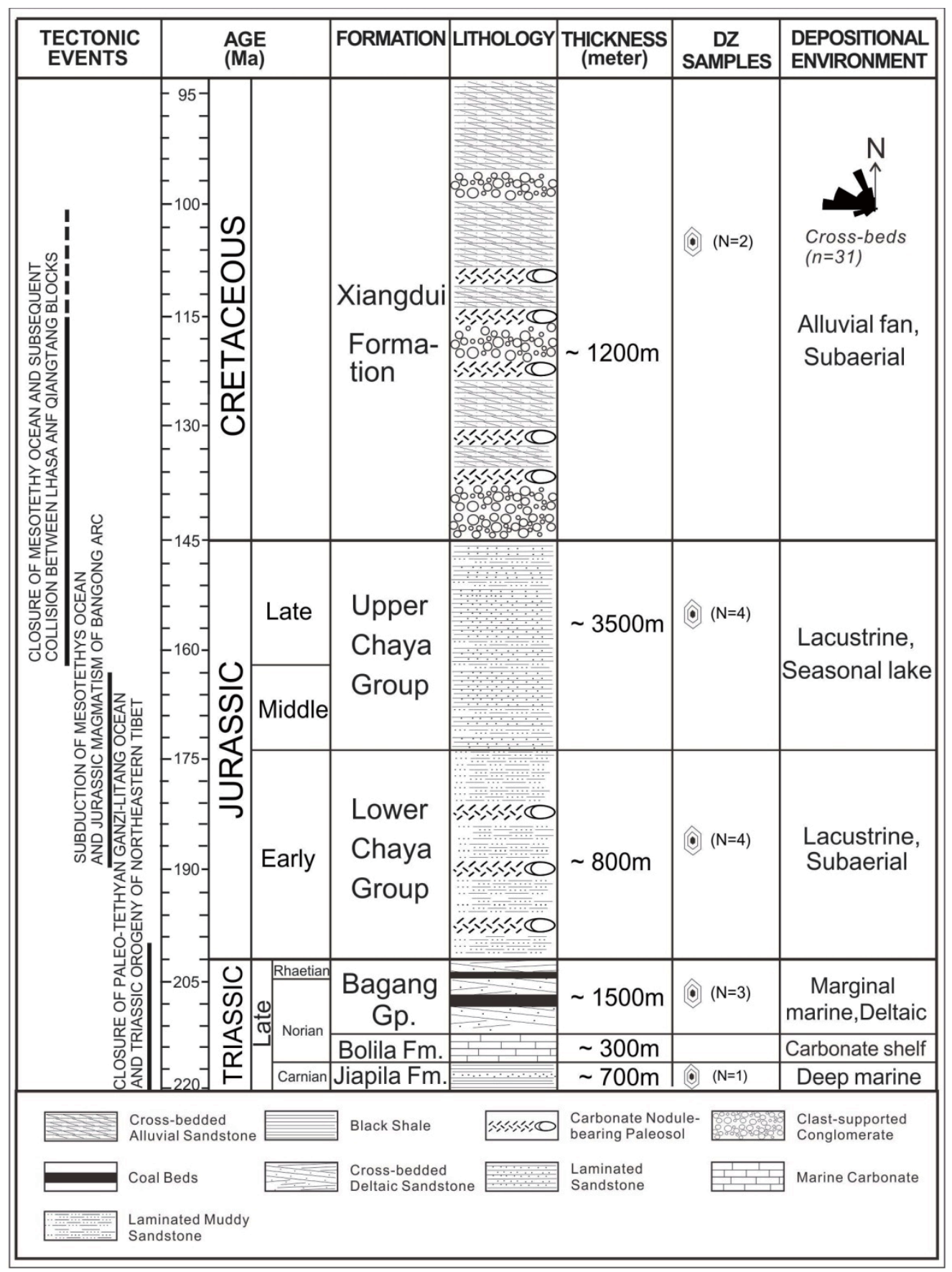

Figure 2. Generalized stratigraphic column for the Qamdo Basin, modified from Du et al. (1997), with stratigraphic location of detrital zircon samples, timing of regional tectonic events (from Kapp et al., 2005; 2007; Roger et al., 2008), paleo-flow directions, and interpretation of depositional environments. Time scale is from Gradstein et al. (2004). Where multiple detrital zircon samples of a formation have been analyzed, the total number is in parentheses. 


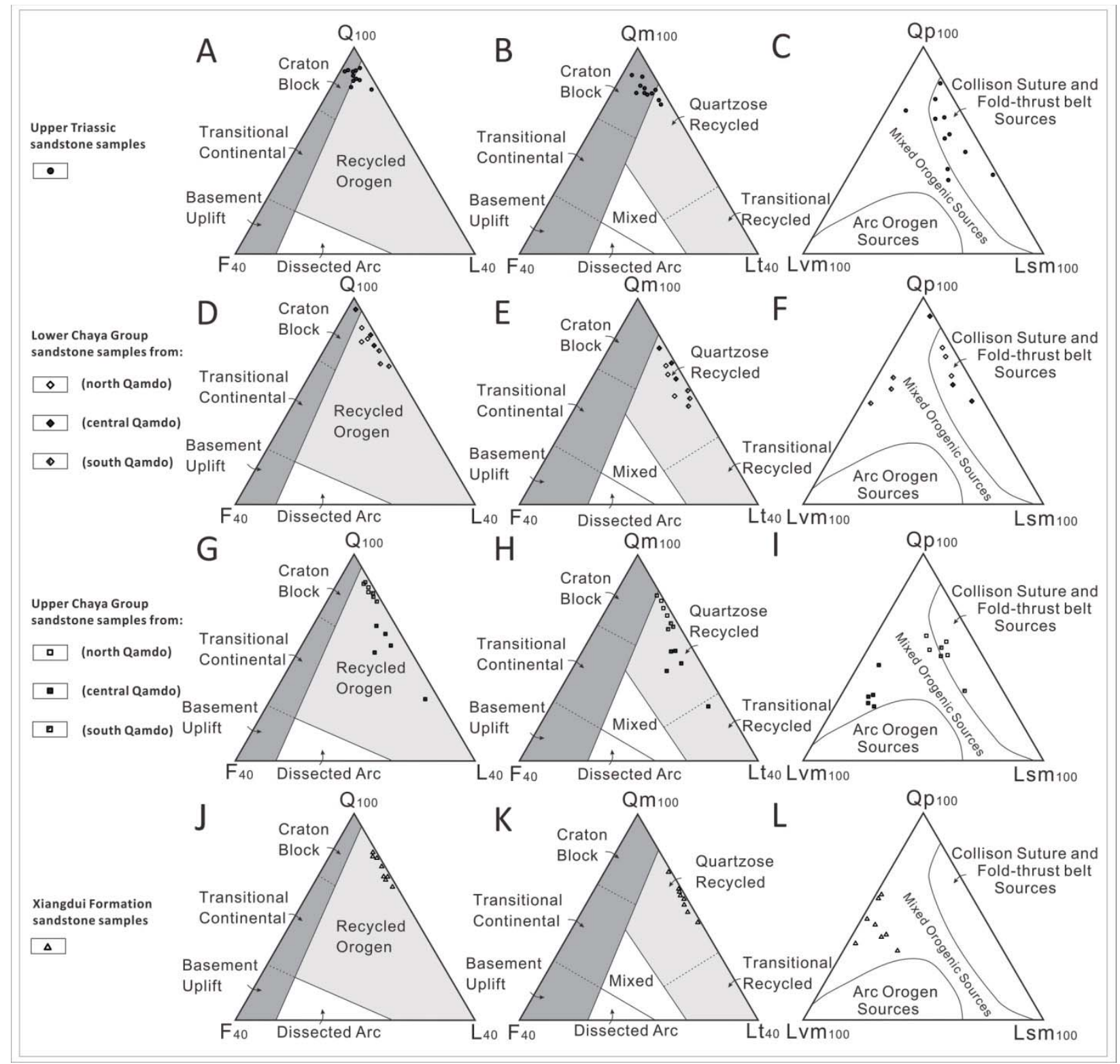

Figure 3. Detrital modes of Upper Triassic-Cretaceous sandstone samples from the Qamdo Basin. Data are listed in Table DR1. Provenance fields of QtFL and QmFLt ternary plots are after Dickinson (1985). Adapted from Xing et al. (2013). QtFL - total quartz-feldspar-lithic fragment; QmFLt - monocrystalline quartz-feldspar-total lithic fragment. 

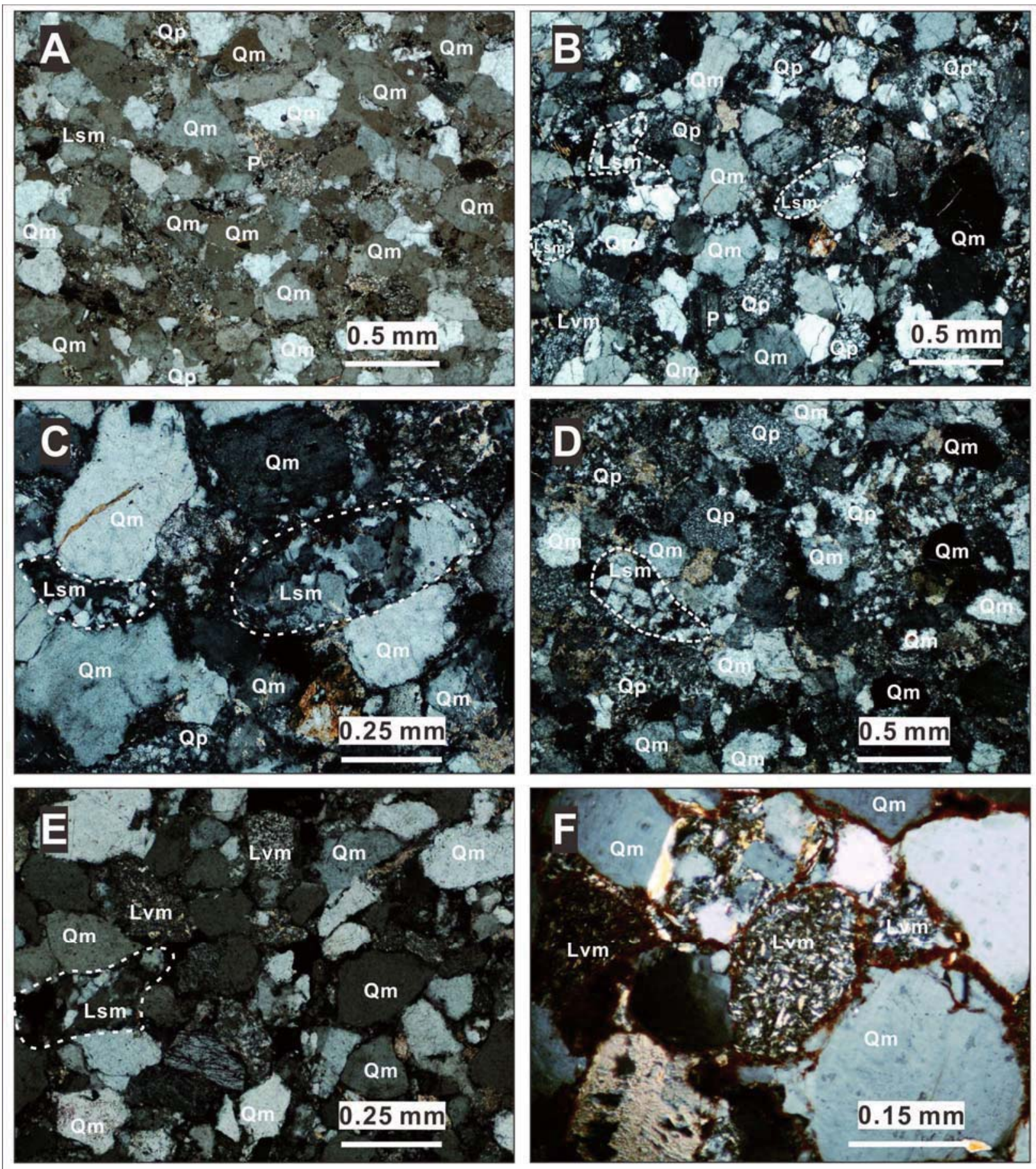

Figure 4. Photomicrographs of the sandstone thin section samples from the Qamdo basin. (A) Upper Triassic sandstone characterized by high monocrystalline quartz content with few sedimentary lithic fragments (Sample UT-3). (B) Lower Chaya sandstone with high polycrystalline quartz abundance (Sample LJ-2). (C) Sedimentary lithic grains in the Lower Chaya sandstone (Sample LJ-2). (D) Sedimentary lithic grains in the Middle-Upper Jurassic 
strata. (E) Upper Chaya sample (MUJ-5) shows high quartz content with few volcanic and sedimentary lithic grains. (F) Volcanic lithic grains found in the Cretaceous sandstone show vitriclastic textures (Sample LK-2). All photomicrographs were taken with cross-polarized light. Qm—monocrystalline quartz; Qp—polycrystalline quartz; P—plagioclase; Lsm—sedimentary and metasedimentary lithic fragments; Lvm—volcanic and metavolcanic lithic fragments. 


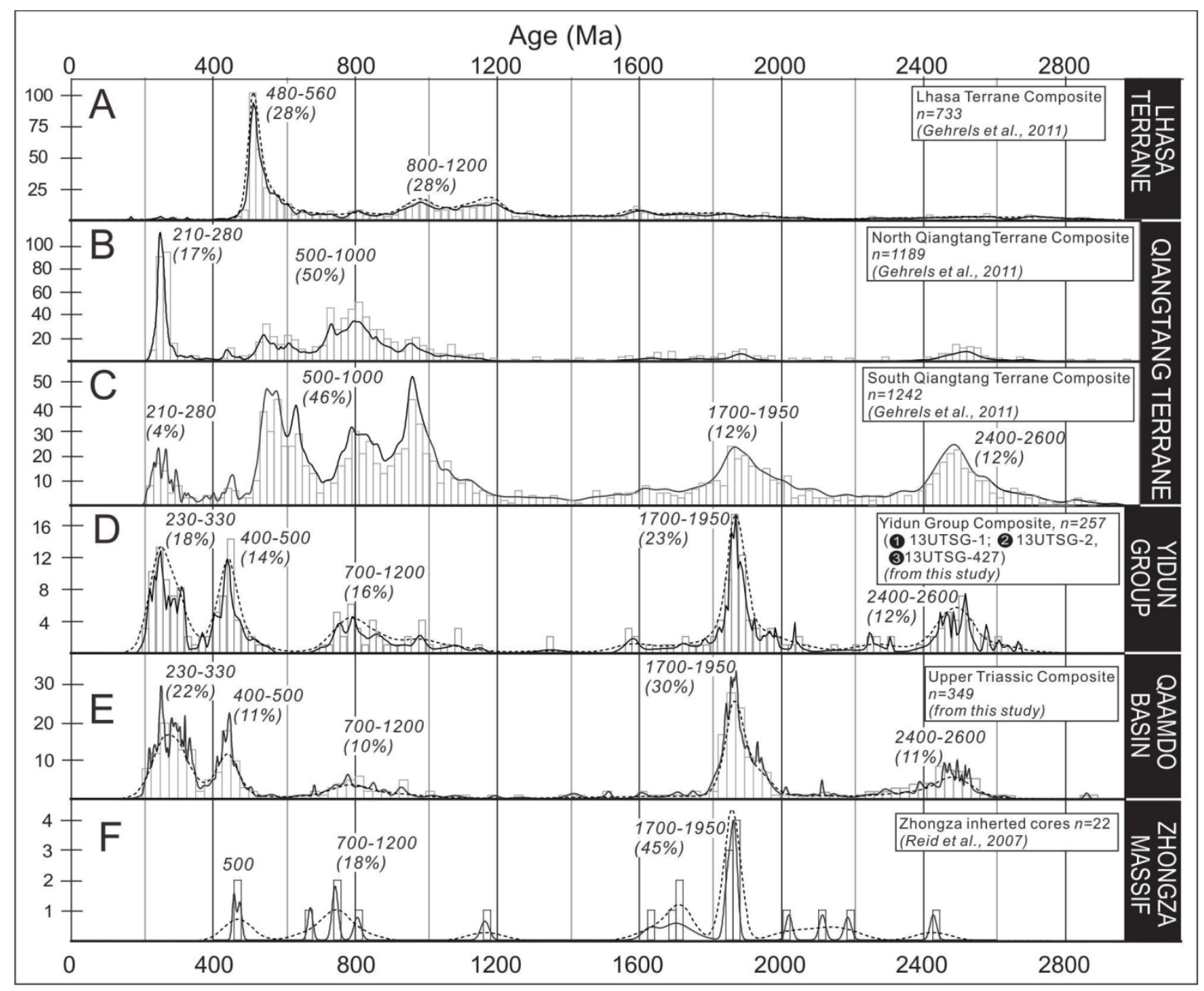

Figure 5. Histograms and zircon age plots of potential source area zircon data (black solid line probability density plot; black dash line — kernel density plot). White number in black circle represents sample locations of reference detrital zircon samples from the Yidun Group shown on Figure 1B. 


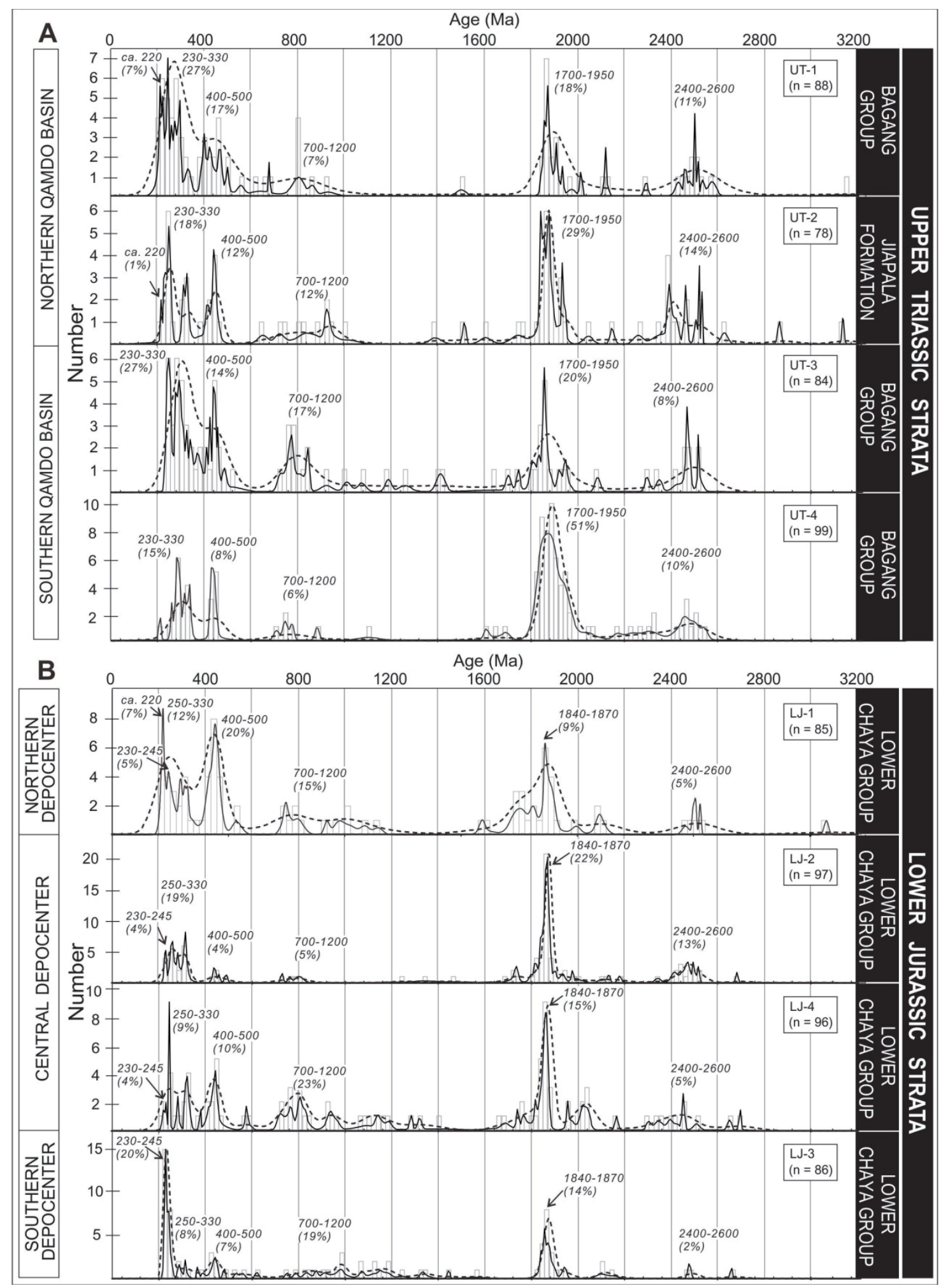

Figure 6. Detrital zircon age distribution probability density plots (black solid line), kernel density plots (black dash line) and histograms for (A) upper Triassic samples and (B) Lower Chaya samples from the Qamdo basin. Sample locations are shown on Figure 1B. 


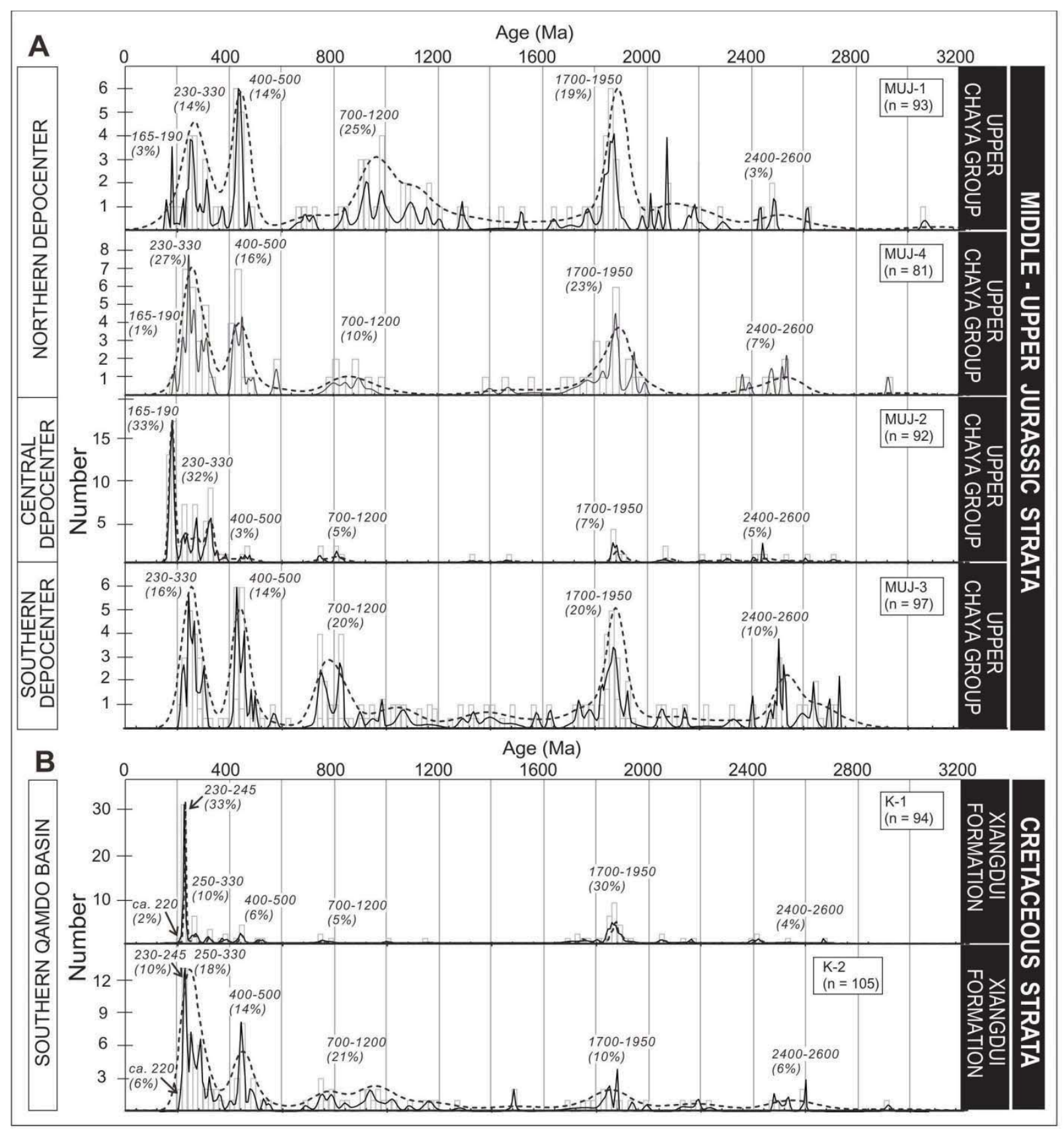

Figure 7. Detrital zircon age distribution probability density plots (black solid line), kernel density plots (black dash line) and histograms for (A) Upper Chaya samples and (B) Cretaceous Xiangdui samples from the Qamdo basin. Sample locations are shown on Figure 1B. 


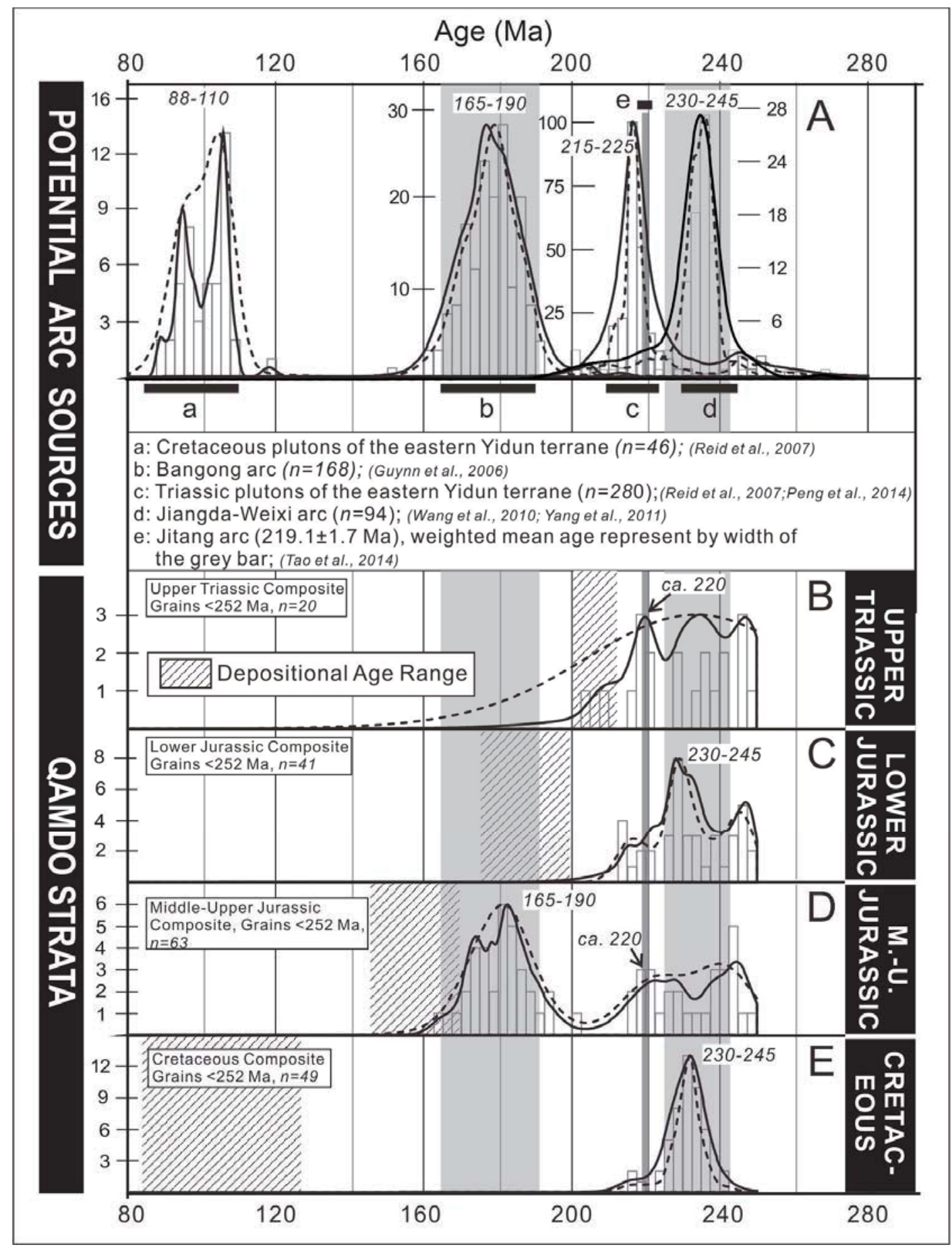

Figure 8. Histograms, probability density plots (black solid line) and kernel density plots (black dash line) of (A) potential arc sources; (B) zircon grains <252 Ma from the Qamdo basin. Gray bars represent prominent arc-signatures observed in detrital record. Sample locations are shown on Figure 1B. 


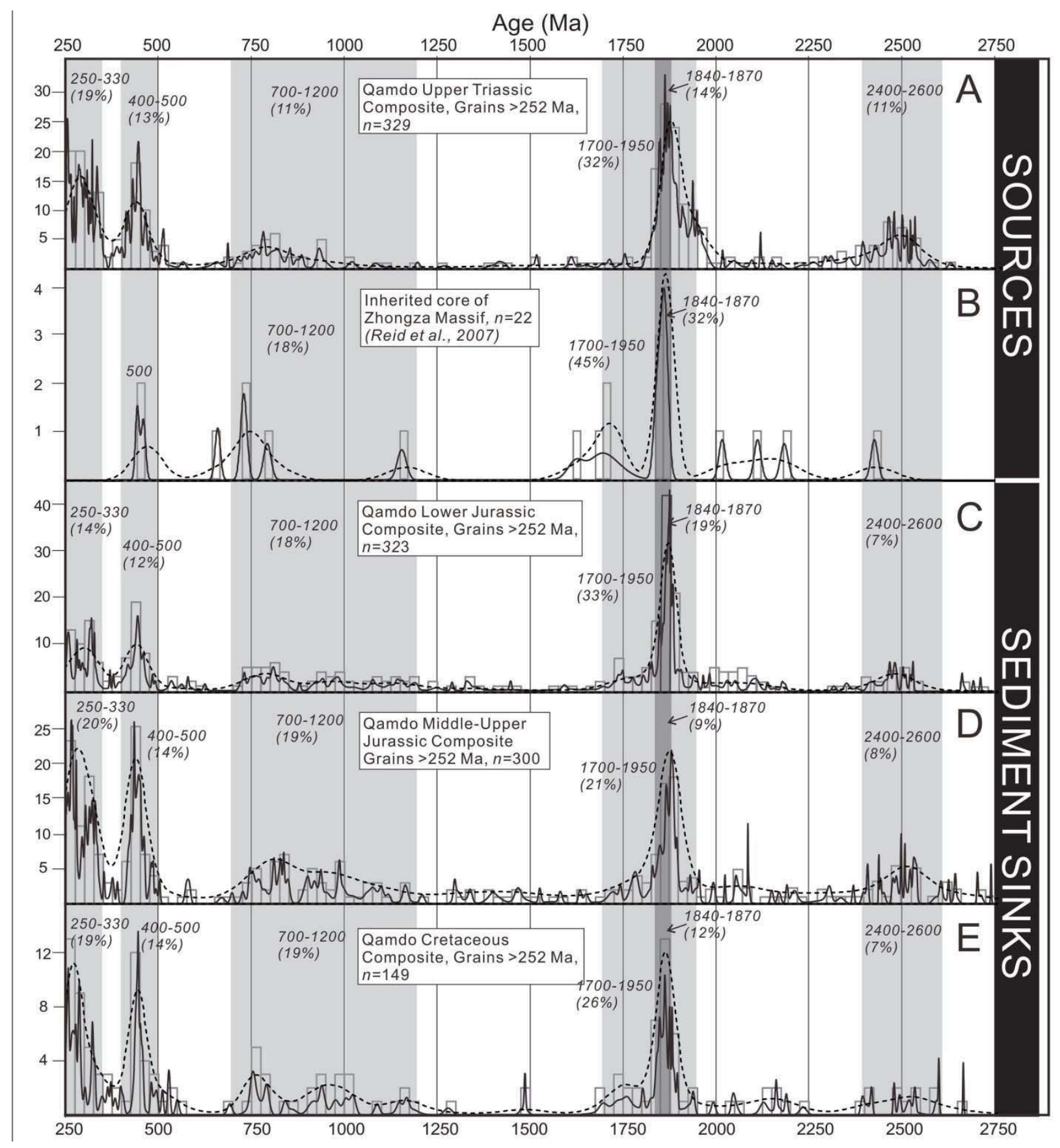

Figure 9. Probability density plots (black solid line) and kernel density plots (black dash line) of zircon ages of the Zhongza mssif and the zircon ages > 252 Ma from the Qamdo basin. Gray bars represent commonly observed age groups in the Qamdo basin. 


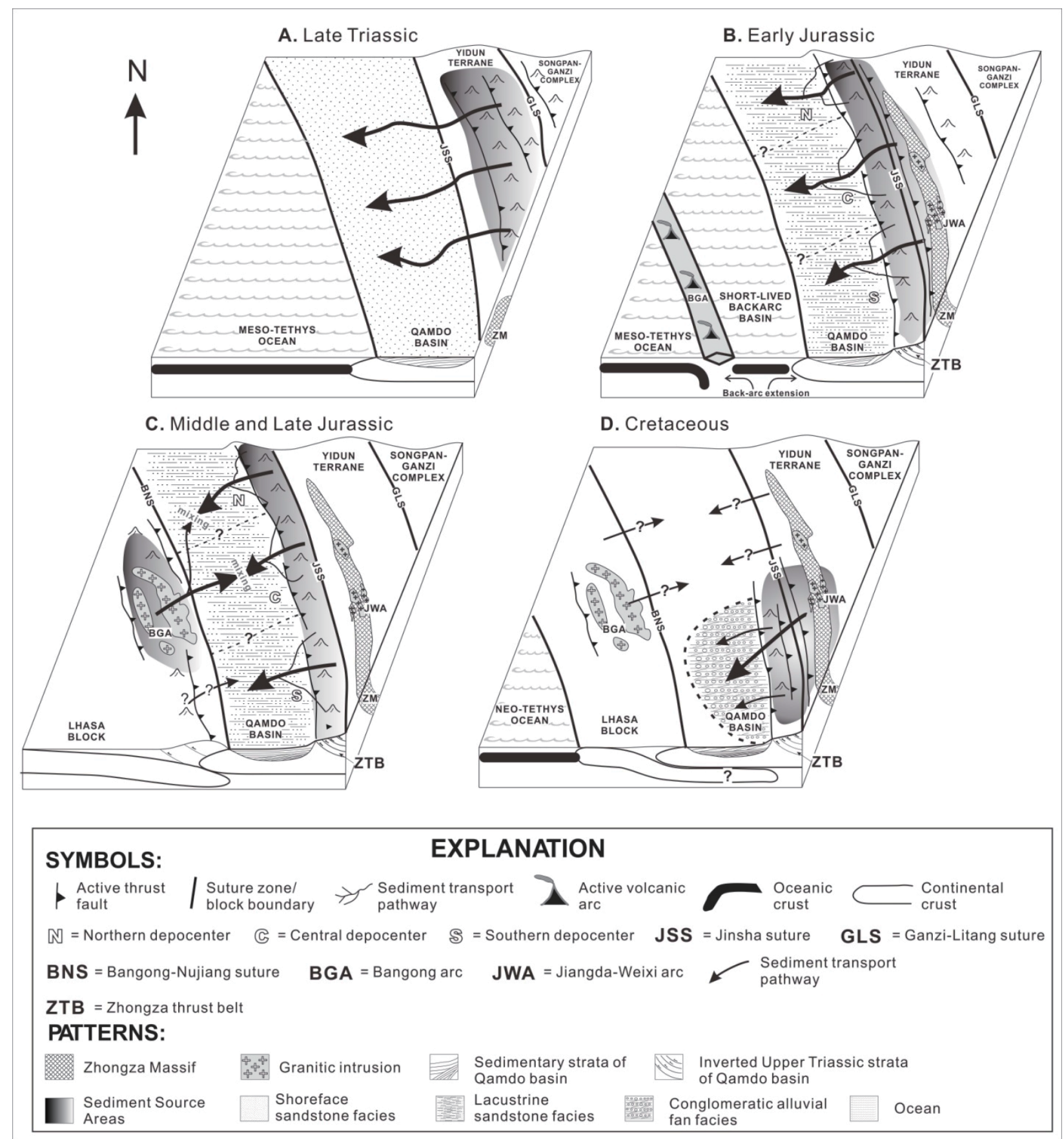

Figure 10. A generalized depositional model for evolution of the Qamdo basin, showing separate depocenters and associated drainages tapping different source areas. (A) Late Triassic (ca.220$200 \mathrm{Ma}$ ) Qamdo basin was primarily sourced from synorogenic detritus derived from folding and exhumation of the Yidun terrane. (B) Early Jurassic (ca.200-175 Ma), three distinct depocenters were developed in the basin due to basin contraction and localized uplift along the Jinsha suture. 
The basin was sourced by the Zhongza massif, the Jomda-Weixi arc, and recycled Upper Triassic Qamdo strata. A short-lived backarc basin to the west of the Qamdo basin prevented the Bangong arc from sourcing the basin. (C) Middle to Late Jurassic (ca.175-145 Ma), abundant Bangong arc-derived sediments started to reach the basin as a result of collision between the Qiangtang and Lhasa blocks, causing uplift and exhumation of the arc. The basin was sourced from both the Bangong arc and internally recycled sources. (D) Cretaceous (ca.145-65 Ma), the basin shrunk significantly toward the south and sediments were derived from the Jomda-Weixi arc and recycled Upper Triassic strata of the Qamdo basin. Cretaceous uplift and exhumation of the Jomda-Weixi arc may related to the underthrusting of the Lhasa block beneath the Qiangtang block (Kapp et al., 2003; 2005; Tian et al., 2014).

${ }^{1}$ GSA Data Repository item xxx, [[Data Repository items include one item list, two figures, two tables and a method description]], is available online at www.geosociety.org/pubs/, or on request from editing@geosociety.org or Documents Secretary, GSA, P.O. Box 9140, Boulder, CO 80301, USA. 
Table 1. U-Pb AGE POPULATIONS AND THEIR PRECENTAGES IN EACH DETRITAL ZIRCON SAMPLES FROM THE QAMDO BASIN

\begin{tabular}{|c|c|c|c|c|c|c|c|c|c|c|c|}
\hline \multirow{2}{*}{$\begin{array}{c}\text { Sample } \\
\text { Name }\end{array}$} & \multirow{2}{*}{$\begin{array}{l}\text { Sam- } \\
\text { ple } \\
\text { Loca } \\
\text {-tion }\end{array}$} & \multicolumn{10}{|c|}{ Age range (Ma) } \\
\hline & & $\begin{array}{c}165- \\
190 \\
\end{array}$ & $\begin{array}{c}\text { ca. } \\
220\end{array}$ & $\begin{array}{c}230- \\
330 \\
\end{array}$ & $\begin{array}{l}(230- \\
245)^{*}\end{array}$ & $\begin{array}{l}(250- \\
330)^{*}\end{array}$ & $\begin{array}{c}400- \\
500 \\
\end{array}$ & $\begin{array}{l}700- \\
1200 \\
\end{array}$ & $\begin{array}{c}1750- \\
1900 \\
\end{array}$ & $\begin{array}{l}(1840- \\
1870)^{*}\end{array}$ & $\begin{array}{c}2400- \\
2600 \\
\end{array}$ \\
\hline \multicolumn{12}{|l|}{ Upper } \\
\hline \multicolumn{12}{|l|}{ Triassic } \\
\hline $\begin{array}{c}\text { UT-1 } \\
(n=88)\end{array}$ & NQB & NA & $7 \%$ & $27 \%$ & $5 \%$ & $20 \%$ & $17 \%$ & $7 \%$ & $18 \%$ & $10 \%$ & $11 \%$ \\
\hline $\begin{array}{l}\text { UT-2 } \\
(\mathrm{n}=78)\end{array}$ & NQB & NA & NA & $18 \%$ & $5 \%$ & $12 \%$ & $12 \%$ & $12 \%$ & $29 \%$ & $13 \%$ & $14 \%$ \\
\hline $\begin{array}{l}\text { UT-3 } \\
(\mathrm{n}=84)\end{array}$ & SQB & NA & NA & $27 \%$ & $4 \%$ & $21 \%$ & $14 \%$ & $17 \%$ & $20 \%$ & $10 \%$ & $8 \%$ \\
\hline $\begin{array}{c}\text { UT-4 } \\
(\mathrm{n}=99)\end{array}$ & SQB & NA & NA & $15 \%$ & NA & $13 \%$ & $8 \%$ & $6 \%$ & $51 \%$ & $13 \%$ & $10 \%$ \\
\hline \multicolumn{12}{|l|}{$\underline{\text { Lower }}$} \\
\hline \multicolumn{12}{|l|}{ Jurassic } \\
\hline $\begin{array}{c}\mathrm{LJ}-1 \\
(\mathrm{n}=85)\end{array}$ & NQB & NA & $7 \%$ & $18 \%$ & $5 \%$ & $12 \%$ & $20 \%$ & $15 \%$ & $25 \%$ & $9 \%$ & $5 \%$ \\
\hline $\begin{array}{l}\text { LJ-2 } \\
(n=97)\end{array}$ & CQB & NA & NA & $23 \%$ & $4 \%$ & $17 \%$ & $4 \%$ & $5 \%$ & $39 \%$ & $22 \%$ & $13 \%$ \\
\hline $\begin{array}{c}\mathrm{LJ}-4 \\
(\mathrm{n}=96)\end{array}$ & CQB & NA & NA & $13 \%$ & $3 \%$ & $9 \%$ & $10 \%$ & $23 \%$ & $23 \%$ & $15 \%$ & $5 \%$ \\
\hline $\begin{array}{c}\mathrm{LJ}-3 \\
(\mathrm{n}=86)\end{array}$ & SQB & NA & NA & $29 \%$ & $19 \%$ & $8 \%$ & $7 \%$ & $19 \%$ & $18 \%$ & $14 \%$ & $2 \%$ \\
\hline \multicolumn{12}{|c|}{ Middle-Upper } \\
\hline \multicolumn{12}{|c|}{ Jurassic } \\
\hline $\begin{array}{l}\text { MUJ-1 } \\
(n=93)\end{array}$ & NQB & $3 \%$ & NA & $14 \%$ & $1 \%$ & $12 \%$ & $14 \%$ & $25 \%$ & $19 \%$ & $8 \%$ & $3 \%$ \\
\hline $\begin{array}{l}\text { MUJ-4 } \\
(n=81)\end{array}$ & NQB & NA & NA & $27 \%$ & $7 \%$ & $19 \%$ & $16 \%$ & $10 \%$ & $23 \%$ & $4 \%$ & $7 \%$ \\
\hline $\begin{array}{l}\text { MUJ-2 } \\
(n=92)\end{array}$ & CQB & $33 \%$ & NA & $32 \%$ & $6 \%$ & $24 \%$ & $3 \%$ & $5 \%$ & $7 \%$ & $2 \%$ & $5 \%$ \\
\hline $\begin{array}{c}\text { MUJ-3 } \\
(n=97)\end{array}$ & SQB & NA & NA & $16 \%$ & $2 \%$ & $12 \%$ & $14 \%$ & $20 \%$ & $20 \%$ & $8 \%$ & $10 \%$ \\
\hline \multicolumn{12}{|l|}{$\underline{\text { Cretaceo }}$} \\
\hline \multicolumn{12}{|l|}{$\underline{\mathrm{uS}}$} \\
\hline $\begin{array}{c}\mathrm{K}-1 \\
(\mathrm{n}=94)\end{array}$ & SQB & NA & $2 \%$ & $43 \%$ & $33 \%$ & $10 \%$ & $6 \%$ & $5 \%$ & $30 \%$ & $14 \%$ & $4 \%$ \\
\hline $\begin{array}{c}\mathrm{K}-2 \\
(\mathrm{n}=105)\end{array}$ & SQB & NA & $6 \%$ & $28 \%$ & $10 \%$ & $18 \%$ & $14 \%$ & $21 \%$ & $10 \%$ & $3 \%$ & $6 \%$ \\
\hline
\end{tabular}

Note: NA-The particular age population is either absent or comprises less than $2 \%$ of total grains.

* Indicating a $\mathrm{U}-\mathrm{Pb}$ age sub-population. 
Abbreviations: NQB—Northern Qamdo Basin; CQB—Central Qamdo Basin; SQB—Southern Qamdo Basin. 
Table 2. P-VALUES FROM K-S STATISTICAL TEST OF TOTAL DETRITAL ZIRCON POPULATIONS

\begin{tabular}{|c|c|c|c|c|c|c|c|c|c|c|c|c|c|c|}
\hline & $\begin{array}{c}\text { UT } \\
-1\end{array}$ & $\begin{array}{c}\text { UT } \\
-2\end{array}$ & $\begin{array}{c}\text { UT } \\
-3\end{array}$ & $\begin{array}{c}\text { UT } \\
-4\end{array}$ & $\begin{array}{c}\text { LJ- } \\
1\end{array}$ & $\begin{array}{c}\text { LJ- } \\
2\end{array}$ & $\begin{array}{c}\text { LJ- } \\
3 \\
\end{array}$ & $\begin{array}{c}\text { LJ- } \\
4\end{array}$ & $\begin{array}{c}\text { MUJ } \\
-1 \\
\end{array}$ & $\begin{array}{c}\text { MUJ } \\
-2 \\
\end{array}$ & $\begin{array}{c}\text { MUJ } \\
-3 \\
\end{array}$ & $\begin{array}{c}\text { MUJ } \\
-4 \\
\end{array}$ & K-1 & K-2 \\
\hline \multirow{2}{*}{ UT-1 } & \multirow{2}{*}{$\mathrm{X}$} & 0.0 & 0.6 & 0.0 & 0.5 & 0.0 & 0.4 & 0.0 & 0.01 & 0.00 & 0.02 & 0.93 & 0.0 & 0.0 \\
\hline & & 12 & 14 & 00 & 71 & 00 & 30 & 02 & 4 & 0 & 0 & 5 & 29 & 92 \\
\hline \multirow{2}{*}{ UT-2 } & 0.0 & & 0.0 & 0.2 & 0.0 & 0.5 & 0.0 & 0.5 & 0.09 & 0.00 & 0.25 & 0.05 & 0.0 & 0.0 \\
\hline & 12 & $\lambda$ & 25 & 10 & 15 & 66 & 12 & 90 & $\mathbf{0}$ & 0 & 7 & 8 & 02 & 00 \\
\hline \multirow{2}{*}{ UT-3 } & 0.6 & 0.0 & \multirow{2}{*}{$\mathrm{X}$} & 0.0 & 0.9 & 0.0 & 0.0 & 0.0 & 0.04 & 0.00 & 0.21 & 0.70 & 0.0 & 0.2 \\
\hline & 14 & 25 & & 00 & 48 & 00 & 61 & 53 & 7 & 0 & $\mathbf{0}$ & 3 & 00 & 78 \\
\hline \multirow{2}{*}{ UT-4 } & 0.0 & 0.2 & 0.0 & \multirow[b]{2}{*}{$\mathrm{X}$} & 0.0 & 0.2 & 0.0 & 0.0 & 0.00 & 0.00 & 0.00 & 0.00 & 0.0 & 0.0 \\
\hline & 00 & 10 & 00 & & 00 & 31 & 00 & 02 & 0 & 0 & 0 & 0 & 00 & 00 \\
\hline \multirow{2}{*}{ LJ-1 } & 0.5 & 0.0 & 0.9 & 0.0 & \multirow{2}{*}{$X$} & 0.0 & 0.4 & 0.0 & 0.16 & 0.00 & 0.37 & 0.91 & 0.0 & 0.2 \\
\hline & 71 & 15 & 48 & 00 & & 00 & 57 & 62 & 6 & 0 & 7 & 2 & 06 & 10 \\
\hline \multirow{2}{*}{ LJ-2 } & 0.0 & 0.5 & 0.0 & 0.2 & 0.0 & \multirow[b]{2}{*}{$\mathrm{X}$} & 0.0 & 0.0 & 0.00 & 0.00 & 0.00 & 0.00 & 0.0 & 0.0 \\
\hline & 00 & 66 & 00 & 31 & 00 & & 00 & 29 & 0 & 0 & 4 & 1 & 00 & 00 \\
\hline \multirow{2}{*}{ LJ-3 } & 0.4 & 0.0 & 0.0 & 0.0 & 0.4 & 0.0 & \multirow[b]{2}{*}{$\mathrm{X}$} & 0.0 & 0.12 & 0.00 & 0.15 & 0.79 & 0.3 & 0.3 \\
\hline & 30 & 12 & 61 & 00 & 57 & 00 & & 61 & 7 & 0 & 3 & 3 & 38 & 23 \\
\hline \multirow{2}{*}{ LJ-4 } & 0.0 & 0.5 & 0.0 & 0.0 & 0.0 & 0.0 & 0.0 & \multirow{2}{*}{ 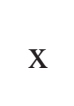 } & 0.75 & 0.00 & 0.76 & 0.03 & 0.0 & 0.0 \\
\hline & 02 & 90 & 53 & 02 & 62 & 29 & 61 & & 5 & 0 & 2 & 3 & 00 & 03 \\
\hline MUJ & 0.0 & 0.0 & 0.0 & 0.0 & 0.1 & 0.0 & 0.1 & 0.7 & & 0.00 & 0.73 & 0.13 & 0.0 & 0.0 \\
\hline-1 & 14 & 90 & 47 & 00 & 66 & 00 & 27 & 55 & $x$ & 0 & 6 & O & 01 & 11 \\
\hline MUJ & 0.0 & 0.0 & 0.0 & 0.0 & 0.0 & 0.0 & 0.0 & 0.0 & 0.00 & & 0.00 & 0.00 & 0.0 & 0.0 \\
\hline-2 & 00 & 00 & 00 & 00 & 00 & 00 & 00 & 00 & 0 & $X$ & 0 & 0 & 00 & 00 \\
\hline MUJ & 0.0 & 0.2 & 0.2 & 0.0 & 0.3 & 0.0 & 0.1 & 0.7 & 0.73 & 0.00 & & 0.17 & 0.0 & 0.0 \\
\hline-3 & 20 & 57 & 10 & 00 & 77 & 04 & 53 & 62 & 6 & 0 & $\mathrm{X}$ & 5 & 01 & 17 \\
\hline MUJ & 0.9 & 0.0 & 0.7 & 0.0 & 0.9 & 0.0 & 0.7 & 0.0 & 0.13 & 0.00 & 0.17 & & 0.0 & 0.2 \\
\hline-4 & 35 & 58 & 03 & 00 & 12 & 01 & 93 & 33 & $\mathbf{0}$ & 0 & 5 & $x$ & 37 & 26 \\
\hline $\mathrm{K}-1$ & 0.0 & 0.0 & 0.0 & 0.0 & 0.0 & 0.0 & 0.3 & 0.0 & 0.00 & 0.00 & 0.00 & 0.03 & & 0.0 \\
\hline & 29 & 02 & 00 & 00 & 06 & 00 & 38 & 00 & 1 & 0 & 1 & 7 & $X$ & 66 \\
\hline K-2 & 0.0 & 0.0 & 0.2 & 0.0 & 0.2 & 0.0 & 0.3 & 0.0 & 0.01 & 0.00 & 0.01 & 0.22 & 0.0 & $\mathrm{X}$ \\
\hline$n-2$ & 92 & 00 & 78 & 00 & 10 & 00 & 23 & 03 & 1 & 0 & 7 & 6 & 66 & 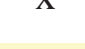 \\
\hline $\mathrm{LH}$ & 0.0 & 0.0 & 0.0 & 0.0 & 0.0 & 0.0 & 0.0 & 0.0 & 0.00 & 0.00 & 0.00 & 0.00 & 0.0 & 0.0 \\
\hline & 00 & 00 & 00 & 00 & 00 & 00 & 00 & 00 & 0 & 0 & 0 & 0 & 00 & 00 \\
\hline QT- & 0.0 & 0.0 & 0.0 & 0.0 & 0.0 & 0.0 & 0.0 & 0.0 & 0.00 & 0.00 & 0.00 & 0.00 & 0.0 & 0.0 \\
\hline $\mathrm{N}$ & 00 & 00 & 00 & 00 & 01 & 00 & 03 & 00 & 0 & 0 & 0 & 0 & 00 & 00 \\
\hline QT- & 0.0 & 0.0 & 0.0 & 0.0 & 0.0 & 0.0 & 0.0 & 0.0 & 0.00 & 0.00 & 0.00 & 0.00 & 0.0 & 0.0 \\
\hline $\mathrm{S}$ & 00 & 00 & 00 & 00 & 00 & 00 & 00 & 02 & 0 & 0 & 0 & 0 & 00 & 00 \\
\hline & 0.0 & 0.7 & 0.1 & 0.0 & 0.0 & 0.0 & 0.0 & 0.5 & 0.33 & 0.00 & 0.87 & 0.17 & 0.0 & 0.0 \\
\hline $1 D U$ & 13 & 18 & 14 & 00 & 86 & 07 & 46 & 81 & 4 & 0 & 2 & 6 & 00 & 00 \\
\hline UT- & 0.0 & 0.6 & 0.0 & 0.0 & 0.0 & 0.0 & 0.0 & 0.2 & 0.09 & 0.00 & 0.39 & 0.08 & 0.0 & 0.0 \\
\hline QB & 44 & 41 & 29 & 02 & 14 & 19 & 15 & 88 & 2 & 0 & 4 & 1 & 00 & 00 \\
\hline
\end{tabular}

Note: Abbreviations: LH-Lhasa Terrane Composite; QT-N-North Qiangtang Terrane Composite; QT-S-South Qiangtang Terrane Composite;

YDG-Yidun Group Composite; UT-QB-Qamdo Basin Upper Triassic Composite.

Bold type denotes $\mathrm{P}>0.05$. Shaded areas show P-values from comparisons of Qamdo samples 
with potential sources. 
Table 3. P-VALUES FROM K-S STATISTICAL TEST OF MESOZOIC MAGMATIC ARCDERIVED DETRITAL ZIRCON POPULATIONS (U-Pb AGES <252 MA)

\begin{tabular}{ccccc}
\hline \hline & UT & LJ & MUJ & K \\
\hline UT & & $\mathbf{0 . 9 1 8}$ & 0.001 & $\mathbf{0 . 3 3 5}$ \\
LJ & $\mathbf{0 . 9 1 8}$ & & 0.000 & $\mathbf{0 . 2 5 1}$ \\
MUJ & 0.001 & 0.000 & & 0.000 \\
K & $\mathbf{0 . 3 3 5}$ & $\mathbf{0 . 2 5 1}$ & 0.000 & \\
EYDT-K & 0.000 & 0.000 & 0.000 & 0.000 \\
BGA & 0.000 & 0.000 & 0.000 & 0.000 \\
EYDT-TR & 0.006 & 0.000 & 0.000 & 0.000 \\
JWA & $\mathbf{0 . 3 2 1}$ & $\mathbf{0 . 3 2 7}$ & 0.000 & $\mathbf{0 . 0 5 9}$ \\
\hline
\end{tabular}

Note: Abbreviations: UT-Upper Triassic Composite; LJ-Lower Jurassic Composite; MUJ-Middle-Upper Jurassic Composite; K-Cretaceous Composite; EYDT-K-Cretaceous plutons of the eastern Yidun terrane; EYDT-TR-Triassic plutons of the eastern Yidun terrane; BGA-Bangong Arc; JWA-Jiangda-Weixi Arc.

Bold type denotes $\mathrm{P}>0.05$. Shaded areas show P-values from comparisons of Qamdo samples with potential arc sources. 
Table 4. P VALUES FROM K-S STATISTICAL TEST OF PRE-MESOZOIC DETRITAL ZIRCON POPULATIONS (U-Pb AGE > $252 \mathrm{MA}$ )

\begin{tabular}{|c|c|c|c|c|c|c|c|c|c|c|c|c|c|c|}
\hline & $\begin{array}{l}\text { UT } \\
-1\end{array}$ & $\begin{array}{l}\text { UT } \\
-2\end{array}$ & $\begin{array}{l}\text { UT } \\
-3\end{array}$ & $\begin{array}{l}\text { UT } \\
-4\end{array}$ & $\begin{array}{c}\mathrm{LJ}- \\
1\end{array}$ & $\begin{array}{c}\text { LJ- } \\
2\end{array}$ & $\begin{array}{c}\mathrm{LJ}- \\
3\end{array}$ & $\begin{array}{c}\text { LJ- } \\
4\end{array}$ & $\begin{array}{c}\text { MUJ } \\
-1\end{array}$ & $\begin{array}{c}\text { MUJ } \\
-2\end{array}$ & $\begin{array}{c}\text { MUJ } \\
-3\end{array}$ & $\begin{array}{c}\text { MUJ } \\
-4\end{array}$ & K-1 & K-2 \\
\hline & & 0.0 & 0.4 & 0.0 & 0.5 & 0.0 & 0.0 & 0.0 & 0.03 & 0.13 & 0.06 & 0.95 & 0.0 & 0.0 \\
\hline \multirow[t]{2}{*}{ UT-1 } & & 29 & 21 & 01 & 75 & 01 & 38 & 06 & 6 & 6 & 1 & 0 & 70 & 79 \\
\hline & 0.0 & & 0.0 & 0.4 & 0.0 & 0.6 & 0.1 & 0.5 & 0.07 & 0.00 & 0.19 & 0.10 & 0.5 & 0.0 \\
\hline \multirow[t]{2}{*}{ UT-2 } & 29 & & 13 & 69 & 23 & 90 & 39 & 53 & 2 & 3 & 4 & 2 & 62 & 00 \\
\hline & 0.4 & 0.0 & & 0.0 & 0.3 & 0.0 & 0.0 & 0.0 & 0.02 & 0.29 & 0.09 & 0.79 & 0.0 & 0.9 \\
\hline \multirow[t]{2}{*}{ UT-3 } & 21 & 13 & & 00 & 63 & 00 & 23 & 16 & 1 & 5 & 6 & 1 & 10 & 54 \\
\hline & 0.0 & 0.4 & 0.0 & & 0.0 & 0.3 & 0.0 & 0.0 & 0.00 & 0.00 & 0.00 & 0.00 & 0.1 & 0.0 \\
\hline \multirow[t]{2}{*}{ UT-4 } & 01 & 69 & 00 & & 00 & 82 & 01 & 09 & 0 & 0 & 1 & 1 & 10 & 00 \\
\hline & 0.5 & 0.0 & 0.3 & 0.0 & & 0.0 & 0.2 & 0.1 & 0.33 & 0.00 & 0.64 & 0.95 & 0.0 & 0.2 \\
\hline \multirow[t]{2}{*}{ LJ-1 } & 75 & 23 & 63 & 00 & & 00 & 91 & 33 & 3 & 4 & 1 & 8 & 78 & 19 \\
\hline & 0.0 & 0.6 & 0.0 & 0.3 & 0.0 & & 0.0 & 0.0 & 0.00 & 0.00 & 0.00 & 0.00 & 0.5 & 0.0 \\
\hline \multirow[t]{2}{*}{ LJ-2 } & 01 & 90 & 00 & 82 & 00 & & 02 & 45 & 0 & 0 & 5 & 4 & 92 & 00 \\
\hline & 0.0 & 0.1 & 0.0 & 0.0 & 0.2 & 0.0 & & 0.7 & 0.99 & 0.00 & 0.57 & 0.26 & 0.0 & 0.0 \\
\hline \multirow[t]{2}{*}{ LJ-3 } & 38 & 39 & 23 & 01 & 91 & 02 & & 23 & 5 & 2 & 2 & 4 & 81 & 55 \\
\hline & 0.0 & 0.5 & 0.0 & 0.0 & 0.1 & 0.0 & 0.7 & & 0.67 & 0.00 & 0.72 & 0.10 & 0.6 & 0.0 \\
\hline LJ-4 & 06 & 53 & 16 & 09 & 33 & 45 & 23 & & 2 & 0 & 4 & 3 & 34 & 15 \\
\hline MUJ & 0.0 & 0.0 & 0.0 & 0.0 & 0.3 & 0.0 & 0.9 & 0.6 & & 0.00 & 0.70 & 0.33 & 0.0 & 0.0 \\
\hline-1 & 36 & 72 & 21 & 00 & 33 & 00 & 95 & 72 & & 1 & 3 & 9 & 41 & 60 \\
\hline MUJ & 0.1 & 0.0 & 0.2 & 0.0 & 0.0 & 0.0 & 0.0 & 0.0 & 0.00 & & 0.00 & 0.03 & 0.0 & 0.0 \\
\hline-2 & 36 & 03 & 95 & 00 & 04 & 00 & 02 & 00 & 1 & & 1 & 4 & 14 & 72 \\
\hline MUJ & 0.0 & 0.1 & 0.0 & 0.0 & 0.6 & 0.0 & 0.5 & 0.7 & 0.70 & 0.00 & & 0.49 & 0.1 & 0.0 \\
\hline-3 & 61 & 94 & 96 & 01 & 41 & 05 & 72 & 24 & 3 & 1 & & 7 & 62 & 49 \\
\hline MUJ & 0.9 & 0.1 & 0.7 & 0.0 & 0.9 & 0.0 & 0.2 & 0.1 & 0.33 & 0.03 & 0.49 & & 0.1 & 0.1 \\
\hline \multirow[t]{2}{*}{-4} & 50 & 02 & 91 & 01 & 58 & 04 & 64 & $\mathbf{0 3}$ & 9 & 4 & 7 & & 74 & 93 \\
\hline & 0.0 & 0.5 & 0.0 & 0.1 & 0.0 & 0.5 & 0.0 & 0.6 & 0.04 & 0.01 & 0.16 & 0.17 & & 0.0 \\
\hline \multirow[t]{2}{*}{ K-1 } & 70 & 62 & 10 & 10 & 78 & 92 & 81 & 34 & 1 & 4 & 2 & 4 & & 00 \\
\hline & 0.0 & 0.0 & 0.9 & 0.0 & 0.2 & 0.0 & 0.0 & 0.0 & 0.06 & 0.07 & 0.04 & 0.19 & 0.0 & \\
\hline \multirow[t]{2}{*}{$\mathrm{K}-2$} & 79 & 00 & 54 & 00 & 19 & 00 & 55 & 15 & 0 & 2 & 9 & 3 & 00 & \\
\hline & 0.0 & 0.0 & 0.0 & 0.0 & 0.0 & 0.0 & 0.0 & 0.0 & 0.00 & 0.00 & 0.00 & 0.00 & 0.0 & 0.0 \\
\hline LH & 00 & 00 & 00 & 00 & 00 & 00 & 09 & 00 & 0 & 0 & 0 & 0 & 00 & 00 \\
\hline QT- & 0.0 & 0.0 & 0.0 & 0.0 & 0.0 & 0.0 & 0.0 & 0.0 & 0.00 & 0.00 & 0.00 & 0.00 & 0.0 & 0.0 \\
\hline $\mathrm{N}$ & 00 & 00 & 00 & 00 & 04 & 00 & 00 & 00 & 0 & 0 & 0 & 2 & 00 & 01 \\
\hline QT- & 0.0 & 0.0 & 0.0 & 0.0 & 0.0 & 0.0 & 0.0 & 0.0 & 0.00 & 0.00 & 0.00 & 0.00 & 0.0 & 0.0 \\
\hline \multirow[t]{2}{*}{$\mathrm{S}$} & 00 & 04 & 00 & 00 & 00 & 00 & 34 & 24 & 0 & 0 & 0 & 0 & 03 & 00 \\
\hline & 0.0 & 0.7 & 0.0 & 0.0 & 0.1 & 0.0 & 0.2 & 0.5 & 0.25 & 0.00 & 0.76 & 0.47 & 0.4 & 0.0 \\
\hline YDG & 39 & 57 & 48 & 03 & 22 & 13 & 82 & 40 & 6 & 0 & 9 & 7 & 88 & 01 \\
\hline UT- & 0.3 & 0.3 & 0.0 & 0.0 & 0.0 & 0.0 & 0.2 & 0.0 & 0.14 & 0.01 & 0.25 & 0.30 & 0.5 & 0.0 \\
\hline \multirow[t]{2}{*}{ QB } & 02 & 70 & 26 & 03 & 51 & 12 & 85 & 84 & 4 & 1 & 5 & 9 & 40 & 01 \\
\hline & 0.0 & 0.3 & 0.0 & 0.1 & 0.0 & 0.3 & 0.1 & 0.4 & 0.08 & 0.00 & 0.21 & 0.03 & 0.2 & 0.0 \\
\hline $\mathrm{ZM}$ & 11 & 75 & 12 & 94 & 74 & 30 & 10 & 90 & 1 & 1 & 9 & 9 & 70 & 04 \\
\hline
\end{tabular}

Note: Abbreviations: LH-Lhasa Terrane Composite; QT-N-North Qiangtang Terrane Composite; QT-S-South Qiangtang Terrane Composite; 
YDG-Yidun Group Composite; UT-QB-Qamdo Basin Upper Triassic Composite. ZM-Zhongza Massif.

Bold type denotes $\mathrm{P}>0.05$. Shaded areas show P-values from comparisons of Qamdo samples with potential sources. 


\section{Chapter II}

\section{Paleosol records of tropical terrestrial temperatures and atmospheric $p \mathrm{CO}_{2}$ levels during the mid-Cretaceous (Cenomanian-Turonian) 'super-greenhouse' world}

\section{Authors:}

Fei Shang ${ }^{1, *}$, Amy L. Weislogel ${ }^{1}$, Shikha Sharma ${ }^{1}$, Ruiqian Chen $^{1}$, and Aradhna K. Tripati ${ }^{2,3}$ Corresponding author contact:

*E-mail: fshang@mix.wvu.edu

Author affiliations:

${ }^{1}$ Department of Geology \& Geography, West Virginia University, Morgantown, West Virginia 26506, USA

${ }^{2}$ Department of Earth, Planetary, and Space Sciences, Department of Atmospheric and Oceanic Sciences, Institute of the Environment and Sustainability, California Nanosystems Institute, University of California, Los Angeles, CA, USA

${ }^{3}$ European Institute of Marine Sciences (IUEM), Université de Brest, UMR6538, Domaines Océaniques, Rue Dumont D’Urville, Plouzané, France

Keywords:

mid-Cretaceous, temperature, atmospheric $\mathrm{pCO}_{2}$, clumped isotopes, climate sensitivity 


\begin{abstract}
The mid-Cretaceous 'super-greenhouse' world of 100 million years ago was characterized by high sea surface temperatures (SSTs), greatly reduced equator-to-pole temperature gradient and high levels of atmospheric $p \mathrm{CO}_{2}$ driven by elevated rates of seafloor spreading. Although many mid-Cretaceous paleoclimate reconstructions have been published for marine environment, little is known about the evolution of terrestrial temperatures, especially during the Cenomanian-Turonian (C-T) interval ( 101-90 Ma). To improve our understanding of terrestrial climate response to the mid-Cretaceous 'super-greenhouse' world, we apply the carbonate clumped isotope paleothermometry and paleosol $\mathrm{CO}_{2}$ paleobarometry on paleosol carbonates collected from an alluvial sequence that spans the $\mathrm{C}$ - $\mathrm{T}$ interval in southeastern Tibet of China. $\Delta_{47}$-derived soil temperature $\left(\Delta_{47}-\mathrm{T}\right)$ and $p \mathrm{CO}_{2}$ reconstructions reveal that average summer temperatures in tropics $\left(\sim 15^{\circ} \mathrm{N}\right)$ were $\sim 35^{\circ} \mathrm{C}$ with estimated $p \mathrm{CO}_{2}$ levels at $\sim 614 \mathrm{ppmV}$ during the Cenomanian, followed by a warming of $\sim 11{ }^{\circ} \mathrm{C}$ coincident with increase of $p \mathrm{CO}_{2}$ levels by $>40 \%$ at the C-T boundary. During the Turonian, $\Delta_{47}-\mathrm{T}$ and $p \mathrm{CO}_{2}$ values dropped to $\sim 44{ }^{\circ} \mathrm{C}$ and $\sim 775 \mathrm{ppmV}$, respectively. The reconstructed terrestrial temperature trend mirrors coeval tropical SST records, and agrees with mid-Cretaceous climate simulation showing high land surface temperatures in tropics. Our estimate of regional climate sensitivity during midCretaceous yields an average value of $\sim 10{ }^{\circ} \mathrm{C}$ per $\mathrm{CO}_{2}$ doubling, consistent with the view that Earth's climate response to increasing $p \mathrm{CO}_{2}$ level was significantly enhanced in greenhouse world conditions.
\end{abstract}




\section{Introduction}

The Cenomanian-Turonian (C-T) interval ( 101-90 million years ago) of the midCretaceous was characterized by an extraordinary warm 'hothouse' climate superimposed on the greenhouse conditions of the Cretaceous (e.g., Bice et al., 2003; Bice et al., 2006; Huber et al., 2002; Jenkyns et al., 2004; Norris et al., 2002; Schouten et al., 2003; Wilson et al., 2002). Proxy data indicate sea surface temperatures (SSTs) may have reached $33-36{ }^{\circ} \mathrm{C}$ in the tropics (Norris et al., 2002; Schouten et al., 2003; Wilson et al., 2002), 30-32 ${ }^{\circ} \mathrm{C}$ in the southern Atlantic Ocean $\left(60^{\circ} \mathrm{S}\right.$ paleolatitude) (Bice et al., 2003), and $>20^{\circ} \mathrm{C}$ in the Arctic ocean (Jenkyns et al., 2004), implying a substantially reduced equator-to-pole temperature gradient (e.g., Huber et al., 1995). Geochemical study of brachiopod shells from subtropical and mid-latitude shelf-sea environments reveals a long-term warming trend within the C-T interval, with a dramatic temperature rise of $4-5{ }^{\circ} \mathrm{C}$ at the C-T boundary (Voigt et al., 2004). Similarly, organic geochemical analyses (the $\mathrm{TEX}_{86}$ proxy) of mudstones recovered in sediment cores from the deep tropical Atlantic Ocean have revealed a gradual warming trend, with SSTs rising from 31 ${ }^{\circ} \mathrm{C}$ in the early Cenomanian to $\sim 36{ }^{\circ} \mathrm{C}$ in the Turonian (Forster et al., 2007). The $\mathrm{C}-\mathrm{T}$ global warming is coeval with a worldwide oceanic anoxic event (i.e., Bonarelli event or OAE 2), causing widespread deposition of organic-rich black shales (e.g., Jenkyns, 2010) and global extinction of marine biota (Sepkoski Jr, 1986), with extinction rates locally reaching up to $79 \%$ for macro-invertebrates (i.e., in the Western Interior Seaway of the USA) (Harries and Little, 1999). The high temperatures observed during the mid-Cretaceous have been commonly attributed to elevated atmospheric greenhouse gas levels, with increased $p \mathrm{CO}_{2}$ driven by enhanced volcanism (e.g., Arthur et al., 1985). Atmospheric $p \mathrm{CO}_{2}$ estimates from geochemical models range from $\sim 1,000$ and $\sim 1,750$ ppm (Bergman et al., 2004; Berner and Kothavala, 2001). 
Values for $\mathrm{pCO}_{2}$ estimated from various proxies such as paleosol barometry, stomatal density, liverworts, and phytoplankton carbon isotope ratios are largely similar to those of the model outputs, but display a slightly larger variation, with most values falling between $\sim 500$ and $\sim 1,500$ ppm (Barclay et al., 2010; Bice et al., 2006; Breecker et al., 2010; Fletcher et al., 2008; Freeman and Hayes, 1992; Van Bentum et al., 2012).

However, most of our knowledge about the mid-Cretaceous climate was derived from marine records, and there is a general paucity of continental record indicating an extraordinary mid-Cretaceous warmth (e.g., Chamberlain et al., 2013), as might be expected. The scarcity of data mainly arises from a lack of quantitative methods for extracting temperature information from terrestrial sedimentary records. Recent development of carbonate clumped-isotope thermometry provides an innovative technique that holds potential for reconstruction of carbonate-formation temperatures over a range of timescales (e.g., Dennis et al., 2013; Eagle et al., 2013; Eiler, 2011; Fan et al., 2014; Garzione et al., 2014; Hough et al., 2014; Huntington et al., 2015; Petryshyn et al., 2015; Quade et al., 2013; Snell et al., 2014; Snell et al., 2013; Suarez and Passey, 2014; Suarez et al., 2011; Tripati et al., 2010; Tripati et al., 2015; VanDeVelde et al., 2013; Zaarur et al., 2011). Bonding of ${ }^{13} \mathrm{C}$ and ${ }^{18} \mathrm{O}$ ions in carbonate minerals is temperaturedependent, and thus the abundance of ${ }^{13} \mathrm{C}-{ }^{18} \mathrm{O}$ bonds is closely correlated to the formation temperatures of carbonate minerals (Eiler, 2007; Ghosh et al., 2006). The technique has been applied to a few Cretaceous climate studies, including the study of the Early Cretaceous (Berriasian-late Valanginian) marine temperatures in sub-arctic region using mollusk shells (Price and Passey, 2013), the Late Cretaceous (late Campanian and Maastrichtian) climate of Western Interior Seaway of North America using cephalopod fossils (Dennis et al., 2013), and the late Early Cretaceous (Aptian-Albain) terrestrial climate by studying lacustrine carbonates 
from the Xiagou Formation of northwestern China (Suarez et al., 2012), whereas continental temperature records from the $\mathrm{C}-\mathrm{T}$ interval are still lacking.

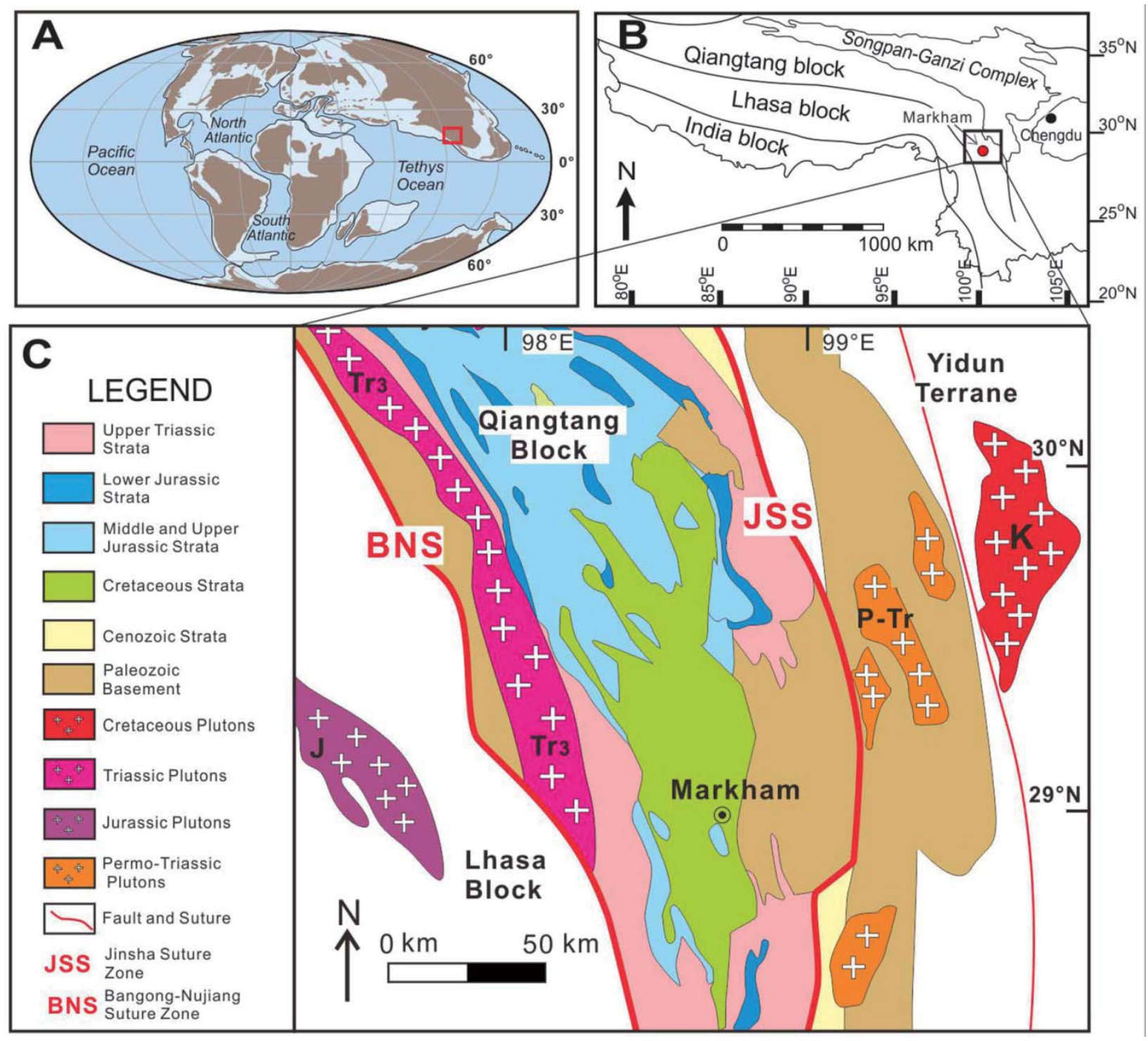

Figure 1. Regional map. (A) Global paleogeographic map of mid-Cretaceous ( $90 \mathrm{Ma}$ ) showing general location of the study area in southeastern Tibet (red square). Figure adapted from Jarvis et al. (2011) based on the paleogeographic reconstruction of Blakey (Blakey, 2008) (B) Simplified geological map of southwestern China showing major tectonic units and block boundaries (Pan et al., 2004). (C) Local geologic map of Markam Area, eastern Tibet (Pan et al., 2004). 
In order to improve our understanding of terrestrial climate evolution in response to changing $\mathrm{pCO}_{2}$ levels and associated global warming during mid-Cretaceous, we examined a paleosol-rich Cretaceous alluvial sequence that spans the C-T interval, located in the Markam County of southeastern Tibet (Fig. 1) using carbonate clumped isotope paleothermometer. Soil forms at the Earth's surface, and directly records climatic and environmental conditions over the period of growth, and thus is a powerful tool for paleoclimate reconstructions (Sheldon and Tabor, 2009). For clumped isotope-based paleoclimate studies, paleosol carbonates have been increasingly used as an archive for reconstruction of terrestrial temperatures (e.g., Eagle et al., 2013; Garzione et al., 2014; Huntington et al., 2015; Passey et al., 2010; Quade et al., 2013; Snell et al., 2013; Suarez et al., 2011). Additionally, atmospheric $\mathrm{CO}_{2}$ concentrations can be modeled using the paleosol carbonate barometer developed by Cerling (1999). If soil carbonate forming temperatures can be constrained by clumped isotope thermometry, then key parameters used for $p \mathrm{CO}_{2}$ estimates based on this barometer (e.g., $\delta^{13} \mathrm{C}_{\mathrm{s}}: \delta^{13} \mathrm{C}$ of soil $\mathrm{CO}_{2}$ and $\mathrm{S}_{\mathrm{z}}$ : soil $\mathrm{CO}_{2}$ concentration) can be more accurately estimated (Breecker and Retallack, 2014; Breecker et al., 2009; Montanez, 2013; Romanek et al., 1992).

Here, we report $\Delta_{47}$-derived soil temperatures $\left(\Delta_{47}-\mathrm{T}\right), \delta^{18} \mathrm{O}$ values of soil water $\left(\delta^{18} \mathrm{O}_{\text {water }}\right)$ and estimated atmospheric $p \mathrm{CO}_{2}$ levels from paleosol carbonate nodules. Influence of diagenesis on soil carbonates is rigorously screened using isotopic, petrographic, chemical techniques to assess if the soil carbonates preserve original isotopic and $\Delta_{47}$ signals. The reconstructed $\Delta_{47}-\mathrm{T}$ and $p \mathrm{CO}_{2}$ values from soil record are compared with marine temperature datasets and mean annual surface-air temperature (MAAT) from Global Climate Model (GCM) simulation (Kump and Pollard, 2008), and existing $p \mathrm{CO}_{2}$ estimates (Barclay et al., 2010; Bice et al., 2006; Breecker et al., 2010; Fletcher et al., 2008; Freeman and Hayes, 1992; Van Bentum et 
al., 2012), respectively, to improve our understanding of regional continental climate response to mid-Cretaceous global warming and Earth's system climate sensitivity in 'super-greenhouse' world.

\section{Geologic and climate settings}

Our study area is located in the Markam County of southeastern Tibet where Cretaceous alluvial strata are present (Fig. 1) (Du et al., 1997; Pan et al., 2004). The Cretaceous sequence was deposited in the southern Qamdo basin developed on top of the eastern Qiangtang block, bounded by the Jinsha suture to the east and the Bangong-Nujiang suture to the west (Fig. 1C). Paleogeographic reconstruction suggests that the study area was located at approximately $15^{\circ} \mathrm{N}$ in a tropical zone during the mid-Cretaceous ( 90 Ma) (Fig. 1A; Blakey, 2008). The Cretaceous strata cover an area of $\sim 2,000 \mathrm{~km}^{2}$ and contain $\sim 1,200 \mathrm{~m}$ thick alluvial deposits composed of clast-supported conglomerate, cross-stratified pebbly red sandstone, and thick-bedded carbonate nodule-bearing paleosol layers (Fig. 2A) underlain by Triassic-Jurassic marine-lacustrine deposits (Du et al., 1997; Pan et al., 2004). Paleosol profiles range from $1.5 \mathrm{~m}$ to up to $8 \mathrm{~m}$ thick and were identified in the field based on lithology (i.e., silty clay), lack of stratification, and presence of carbonate nodules, root traces, bioturbation features, color mottling and ped structures (Fig. 2). Paleosol carbonates occur as discrete nodules ranging from $1-5 \mathrm{~cm}$ in diameter. 


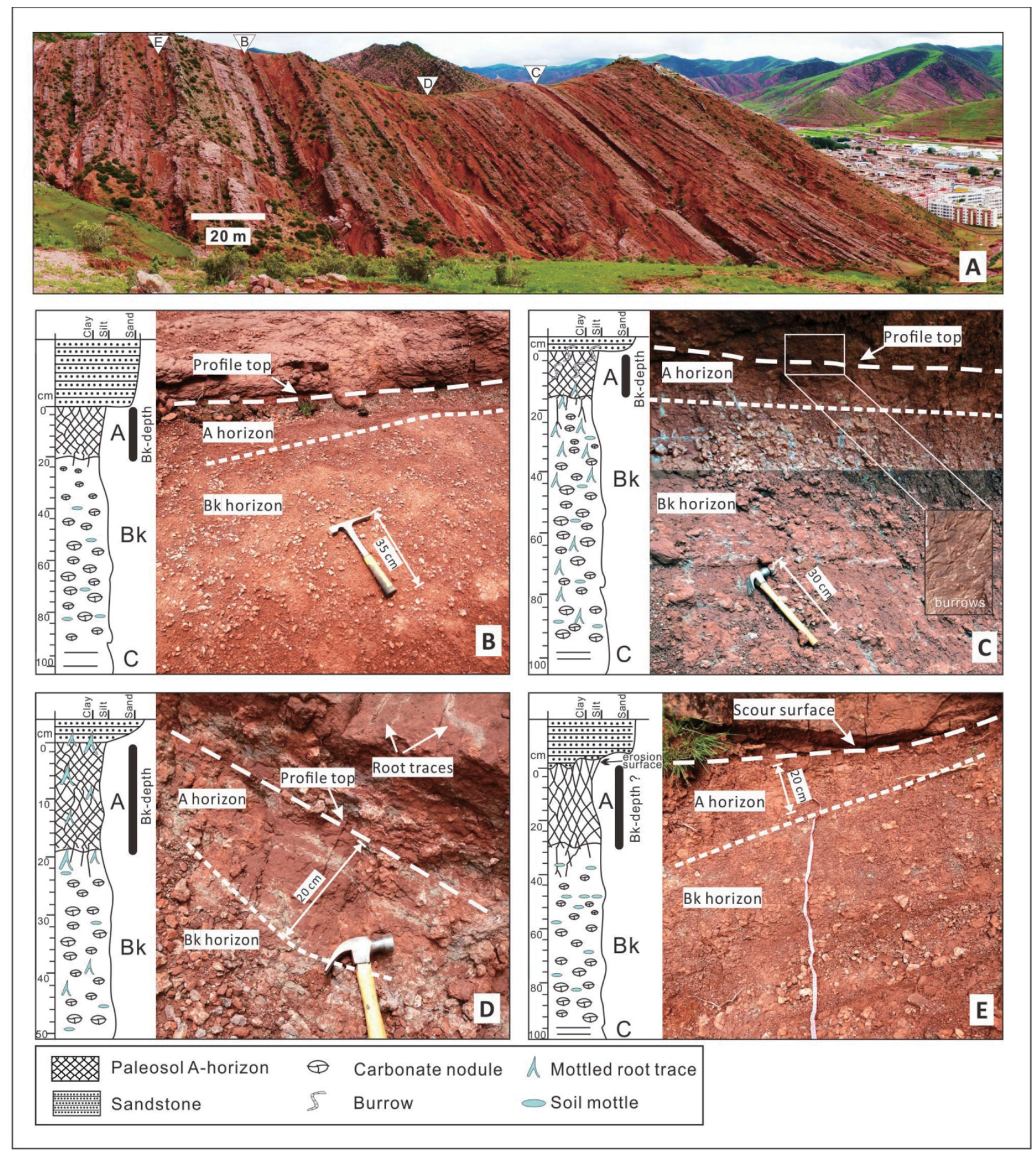

Figure 2. Field photos of Cretaceous section and individual paleosol profiles. (A) Overview of Cretaceous strata composed of clast-supported conglomerate, cross-stratified pebbly red sandstone, and thick-bedded carbonate nodule-bearing paleosol layers. Letters in white triangle indicate positions of individual paleosols shown in Figs. 2B-E. (B-E) Sedimentary logs and photographs of individual paleosol profiles, showing Bk-depth and pedogenic features such as 
root traces, bioturbations, color mottling, ped structures and carbonate nodules.

Paleoclimate reconstructions suggest that our study area was located in a widespread evaporite zone near the equatorial region $\left(\sim 15^{\circ} \mathrm{N}\right)$ during the mid-Cretaceous (Hay and Floegel, 2012). The evaporite zone was characterized by increased aridity and evaporation during the C-T time (Hay and Floegel, 2012). Although C-T terrestrial temperature records from proxies are still lacking, climate model simulations (i.e., GENESIS v. 3.0) show that during mid-Cretaceous ( 100 Ma) 'super-greenhouse' interval, mean annual surface-air temperatures (MAAT) in southeastern Tibet may have reached $35-40{ }^{\circ} \mathrm{C}$ (Kump and Pollard, 2008). If the simulated midCretaceous MAATs are representative, it is very likely that warm-month surface-air temperatures during mid-Cretaceous may even higher in this region.

\section{Stratigraphy and age constraint}

The Cretaceous sequence exposed near the city of Markam is divided into two major units: the Lower Cretaceous Jingxing Formation and the Upper Cretaceous Nanxin Formation (GSX, 2007) (Fig. 3A). The Jingxing Formation consists of $~ 700 \mathrm{~m}$ light grey sandy conglomerate and volcanic lithic arenite in the basal part and transitions upwards to red mediumto coarse-grained sandstone with interbedded Calcisols (Du et al., 1997). The Nanxing Formation consists of $\sim 600 \mathrm{~m}$ of thick-bedded red to purplish lithic sandstone interbedded with layers of conglomerate, pebbly sandstone, mudstones, and carbonate nodule-bearing Calcisols (Du et al., 1997). 


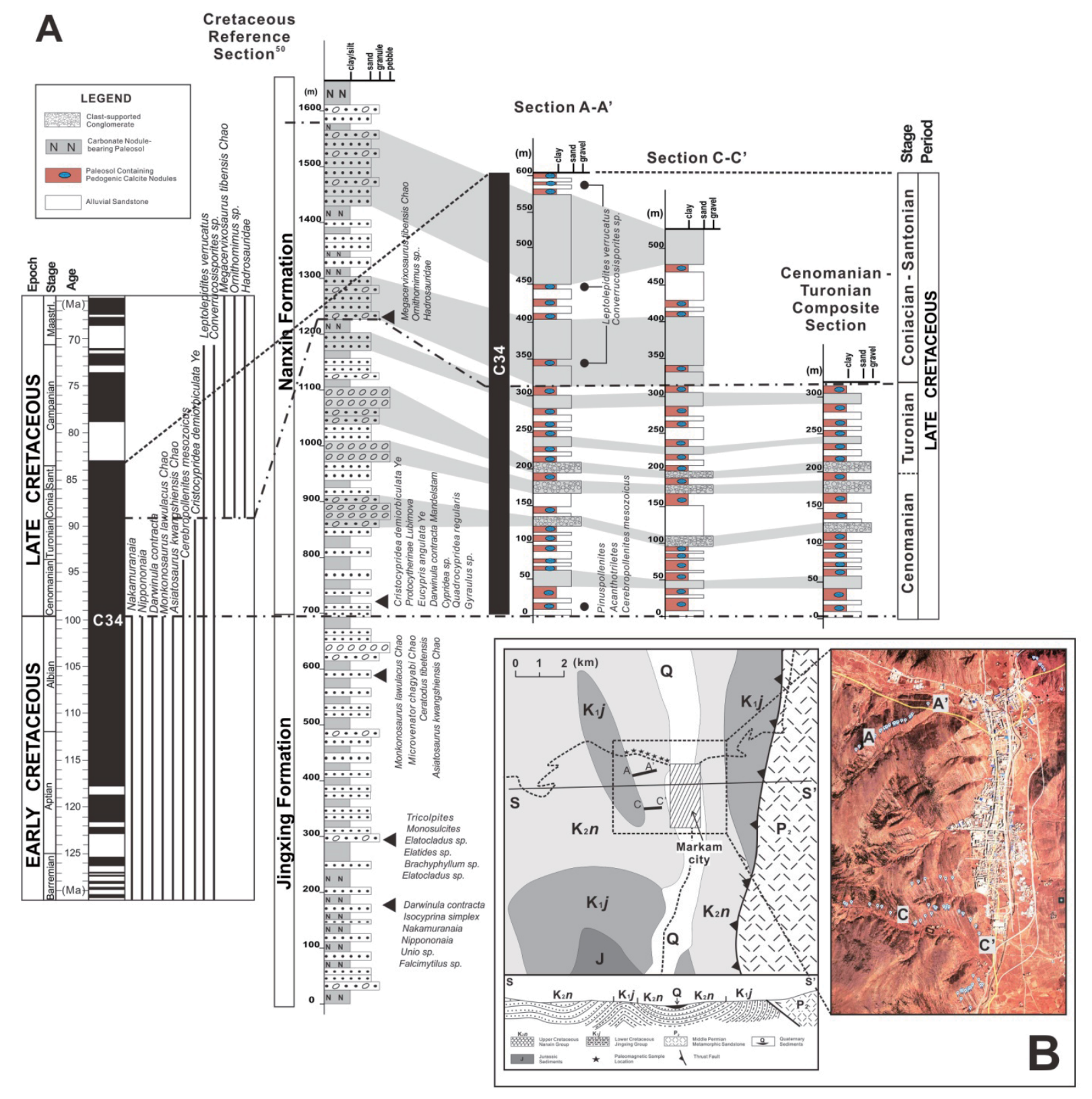

Figure 3. Stratigraphic column and age control. (A) Chronostratigraphy of the Cretaceous sequence. Biostratigraphic controls are compiled from (GSX, 2007), along with the palynological data obtained in this study. Black arrows indicate positions where fossils were found in Cretaceous reference section. Correlations among the Cretaceous reference section, sections A-A', and C-C' are based on lithological marker beds. Black dots indicate palynology sampling positions in the studied sections. Palaeomagnetic data are from Huang et al. (1992) (sampling locations are marked in Fig. 3B by black star signs), correlated to the sections in this study. (B) Local geologic and satellite maps showing the studied sections. 
Stratigraphic boundaries and ages are determined based on paleomagnetic dating (Huang et al., 1992), biostratigaphy and lateral correlations with Cretaceous type sections for the region mapped by Xizang (Tibetan) Geological Survey (GSX, 2007), and palynological analysis conducted in this study (Fig. 3A). The Cretaceous strata in our study area cannot be radiometrically dated since it contains no volcanic ash layers that are suitable for dating, and the youngest detrital zircon age populations of the Cretaceous sediments are all >200 Ma (Shang, 2014). Full list of faunal assemblages and palynological data are included in Supplementary Text 1.

In our studied sections, depositional ages of the Lower Cretaceous Jingxing Formation is constrained at between middle Aptian and Albian (118-100 Ma), whereas the age of the lower Nanxing Formation is constrained at between Cenomanian and Turonian ( 100-89 Ma), and that of the upper Nanxing Formation is at between Coniacian and Santonian ( 89-83 Ma) (Fig. 3A) (GSX, 2007; Gradstein et al., 2004; Huang et al., 1992). The position of the CenomanianTuronian (C-T) boundary in the studied sections is further determined by assuming a constant average sediment accumulation rate, as indicated by relatively continuous stratigraphic deposition with absence of major unconformities and depositional hiatuses (Fig. 2A). Note that when calculating the stratal thickness, thick-bedded conglomerate layers were excluded since they most likely reflect rapid, short-duration depositional events. The C-T boundary was therefore placed at $\sim 200 \mathrm{~m}$ height of the composited section (Fig. 3A).

\section{Methodology}

A total of 21 individual paleosol horizons from the C-T interval were sampled, with 12 samples from section A-A' and 9 samples from section C-C'. Our rationale for sampling the 
same paleosol interval at two different locations ( $\sim 3 \mathrm{~km}$ apart) is that soil temperature can be affected by vegetation shading and local slopes (Quade et al., 2013). Thus, sampling the same paleosol interval at different locations will help us to distinguish between regional paleoclimate signals and local variations. Carbonate nodules were sampled from depth of $\sim 50 \mathrm{~cm}$ below top of the preserved paleosol surface to constrain the variation of soil temperature with depth and reduce the potential effects of soil water evaporation (Quade et al., 2013).

\section{Mineralogical analysis, petrographic analysis and isotopic screening}

Carbonate nodule samples were characterized using a combination of mineralogy, microscopy, petrology and geochemical analyses of $\mathrm{Mg} / \mathrm{Ca}$ and $\mathrm{Sr} / \mathrm{Ca}$ ratios. X-ray diffraction (XRD) analysis was performed on all samples. Diffraction patterns were obtained using a PANalytical X'Pert Pro XRD diffractometer equipped with $\mathrm{Cu}$ Ka radiation at $40 \mathrm{keV}$ and 40 $\mathrm{mA}$. Samples were first powdered and scanned from $10^{\circ}$ to $100^{\circ}$ at $2 \theta$ with a step interval of $0.05^{\circ}$. Carbonate mineralogy was determined using the computer-based Highscore Plus software equipped with a Powder Diffraction File 3 database. In addition, $\mathrm{Sr} / \mathrm{Ca}$ and $\mathrm{Mg} / \mathrm{Ca}$ ratios of all samples from section A-A' were measured using inductively coupled plasma mass spectrometry (ICP-MS) at Actlabs, Canada. Polished petrographic thin-sections were produced for all samples collected from section A-A' $(n=12)$. The thin-sections were examined under transmitted and cross-polarised light to characterize their mineral compositions, pedogenic textures, and carbonate phases.

Before the more time ( $\sim 3 \mathrm{hrs}$ per sample) and material (average sample size $=\sim 10 \mathrm{mg}$ ) consuming clumped isotope analysis, an stable oxygen and carbon isotopic screening was performed on carbonate nodules collected from 11 paleosol horizons span the $\sim 300 \mathrm{~m} \mathrm{C}-\mathrm{T}$ 
interval at the West Virginia University Stable Isotope Lab, using a GasBench device coupled to a Delta Advantage isotope ratio mass spectrometer. Standardization is based on NBS18 and NBS19 for $\delta^{13} \mathrm{C} / \delta^{18} \mathrm{O}$ of carbonate. Analytical precision is better than \pm 0.1 for $\delta^{13} \mathrm{C}$ and $\delta^{18} \mathrm{O}$ (1s), based on repeated analysis of internal standards. Nodules with both micritic and sparry textures (Fig. A.1.) were micro-sampled ( $n=1$ for sparry claicte; $n=2$ for micritic calcite; average sample size $=0.3 \mathrm{mg}$ ) using a low-speed dremel drill. Carbonate powders were analyzed for $\delta^{13} \mathrm{C}$ and $\delta^{18} \mathrm{O}$ values to detect isotopic differences between micritic and co-existing sparry phases (Fig. A.1.), which is useful in characterizing diagenetic histories of carbonate cement (e.g., Garzione et al., 2004).

\section{Clumped-isotope thermometry}

Carbonate clumped-isotope thermometry is an innovative technique that is based on the temperature-dependant bonding of heavy isotopes $\left({ }^{13} \mathrm{C}\right.$ and $\left.{ }^{18} \mathrm{O}\right)$ into bonds $\left(\mathrm{e} . \mathrm{g} .,{ }^{13} \mathrm{C}-{ }^{18} \mathrm{O}-{ }^{16} \mathrm{O}\right)$ in carbonate minerals, which is favored at low temperatures (Eiler, 2007; Ghosh et al., 2006). The abundance of ${ }^{13} \mathrm{C}^{18} \mathrm{O}^{16} \mathrm{O}$ produced on acid digestion of carbonate minerals is measured (Ghosh et al., 2006). The relative abundance of the ${ }^{13} \mathrm{C}^{18} \mathrm{O}^{16} \mathrm{O}$ isotopologue is reported using the variable “ $\Delta_{47} "$ (Eiler and Schauble, 2004). Carbonate-formation temperatures can be calculated by applying published calibrations relating $\Delta_{47}$ values to carbonate formation temperatures (e.g., Tripati et al., 2015).

The approach not only constrains the formation temperature of carbonate minerals, but also makes calculation of $\delta^{18} \mathrm{O}$ value of water from which carbonate grew more accurate because fractionation of $\mathrm{O}^{18}$ between calcite and water is temperature-dependant (Kim and O'Neil, 1997). For soil carbonate, the relationship between soil forming temperature and $\delta^{18} \mathrm{O}_{\text {water }}$ is very useful 
in detecting signs of evaporation and diagenetic effects, as well as discriminating between primary climate signals and diagenetic resetting (Quade et al., 2013).

Carbonate clumped isotope analysis was conducted at University of California, Los Angeles (UCLA), using a specially modified Thermo Fisher 253 gas source mass spectrometer with mass 44-49 ion collectors ("Chewbacca"). Carbonate nodules with homogeneous micritic textures were carefully sampled using a low-speed dremel drill with periodic cooling of the drill pit to avoid potential resetting of the samples. Samples and carbonate standards are first processed using a custom-built automated system for digestion and purification (after Passey et al., 2010) before being transferred to the inlet of the mass spectrometer. For each measurement, 8-10 mg of calcite powder were digested at $90{ }^{\circ} \mathrm{C}$ in phosphoric acid, the resultant $\mathrm{CO}_{2}$ being cryogenically purified before analysis on the mass spectrometer.

The absolute reference frame (ARF) was established by analyzing equilibrium $\mathrm{CO}_{2}$ samples prepared at $1000{ }^{\circ} \mathrm{C}$ and $25^{\circ} \mathrm{C}$. The standard gas are purified and analyzed using the same protocol as gases generated from carbonate samples. For carbonates, the $\Delta_{47}$ values are normalized to $25^{\circ} \mathrm{C}$ using a $0.092 \%$ value from Passey et al. (2010) as recalculated in Henkes et al. (2013), which is within error of the fractionation factor reported by Defliese et al. (2015). Clumped-isotope data for pedogenic calcite are reported relative to the ARF of Dennis et al. (2011). Uncertainties in reported $\Delta_{47}$ values and calculated temperatures include the propagated uncertainty in equilibrated gas determination and in sample measurement. $\Delta_{47}$-temperatures are calculated using the inorganic calibration of Tripati et al. (2015), generated on the same instrument that measurements for this study were made on. For completeness, Supplementary Table 1 also shows estimated temperatures using other published calibrations.

During the clumped isotope analysis, three internal carbonate standards (Carrerra Marble, 
Carmel Chalk and Veinstrom standard) were analyzed multiple times. The mean $\Delta_{47}$ values and standard deviation (SD) of these standards during the period of analysis were $0.390 \pm 0.012 \%$ ( $\mathrm{n}$ $=11), 0.697 \pm 0.014 \%$ o $(\mathrm{n}=8)$, and $0.725 \pm 0.011 \%$ o $(\mathrm{n}=12)$, respectively, which comes to an average lab precision during the period of sample analysis of $0.012 \%$, lower than the long-term lab precision of $0.009 \%$. The standard errors ( 1 s.e.) for $\Delta_{47}$ values are calculated as $\mathrm{SE}=\mathrm{SD} / \mathrm{SQRT}(\mathrm{N})(1)$, where $\mathrm{SD}$ is the observed standard deviation for repeated analyses of samples, and $\mathrm{N}$ is the number of repeated analyses. If the observed SD is smaller than the longterm lab precision $(0.009 \%$ ), $\mathrm{SE}$ is calculated using $\mathrm{SD}=0.009 \%$ (Tripati et al., 2015). Error in $\Delta_{47}-\mathrm{T}$ is calculated by propagating the SE for $\Delta_{47}$ through the Tripati et al. (2015) temperature calibration equation.

\section{Reconstruction of atmospheric $\mathrm{pCO}_{2}$}

We reconstructed atmospheric $\mathrm{CO}_{2}$ concentrations using the paleosol carbonate barometer developed by Cerling (1999) who reported the following equation:

$$
C_{a}=S(z) * \frac{\delta^{13} C_{s}-1.0044 * \delta^{13} C_{r}-4.4}{\delta^{13} C_{a}-\delta^{13} C_{s}}
$$

where $\mathrm{C}_{\mathrm{a}}$ is $p \mathrm{CO}_{2}$ in atmosphere $(\mathrm{ppmV})$. The value of $\mathrm{S}_{\mathrm{Z}}$ (soil-respired $\mathrm{CO}_{2}$ concentration, ppmV) was commonly assumed to be 5000 ppmV (e.g., Ekart et al., 1999), however, recent studies show that this value has been strongly overestimated since soil carbonated only form in dry months when soil respiration rates are low (e.g., Breecker et al., 2009; Hough et al., 2014). Currently, $S_{z}$ value can be estimated using three approaches: 1) correlation between $S_{z}$ values and depth to $\mathrm{B}_{\mathrm{k}}$ horizon (Breecker and Retallack, 2014; Retallack, 2009); 2) soil-order method which assigns specific ranges of $S_{z}$ values for different soil types (Montanez, 2013); and 3) correlation between mean annual precipitation (which also correlates to depth to $\mathrm{B}_{\mathrm{k}}$ horizon) 
(Retallack, 2005) and $\mathrm{S}_{\mathrm{z}}$ (Cotton and Sheldon, 2012). Bk horizons in our studied paleosol profiles occur at relatively shallow depth (Fig. 2) at $\sim 10-31 \mathrm{~cm}$ (average $=21 \mathrm{~cm}$ ), even after burial decompation using a standard compaction formula for aridisols (Table 4) (Sheldon and Retallack, 2001). The $S_{z}$ values estimated using this approach yields values range from 776 to $1531 \mathrm{ppmV}$ (average $=1157 \mathrm{ppmV}$ ) and associated uncertainty for each paleosol profile $\sim \pm 100$ ppmV (Table 4). In cases when paleosol profiles were eroded by overlying alluvial sandstones which can be detected by presence of scour surface (Fig. 2E), $S_{Z}$ values are adopted from the nearest paleosol horizons with better preserved A horizons. The $S_{z}$ values estimated from Bkdepth method are consistent with estimates based on soil-order method (Montanez, 2013). Paleosol in our studied sections are dominated by Calcisols (Fig. 2) and modern observations suggest that carbonate precipitation in Aridisols (and its paleosol analog Calcisols) occurs when $\mathrm{S}_{z}$ values range from 500-2000 ppmv (Montanez, 2013).

Parameters of $\delta^{13} \mathrm{C}_{\mathrm{s}}, \delta^{13} \mathrm{C}_{\mathrm{r}}$, and $\delta^{13} \mathrm{C}_{\mathrm{a}}$, are the stable carbon isotopic compositions of soil $\mathrm{CO}_{2}$, soil-respired $\mathrm{CO}_{2}$, and atmospheric $\mathrm{CO}_{2}$, respectively. $\delta^{13} \mathrm{C}_{\mathrm{s}}$ values can be estimated from measured $\delta^{13} \mathrm{C}_{\text {carbonate }}$ values and growth temperatures $\left(\Delta_{47}-\mathrm{T}\right)$ of pedogenic carbonate, using the temperature-dependent carbon isotopic fractionation equation for calcite and $\mathrm{CO}_{2}($ Romanek et al., 1992). Values for $\delta^{13} C_{\mathrm{r}}$ are normally approximated by the $\delta^{13} \mathrm{C}$ value of soil organic matter $\left(\delta^{13} \mathrm{C}_{\text {org }}\right)$ (e.g., Cerling, 1999), however, microbial decay of soil organic matters may cause enrichment of $\delta^{13} \mathrm{C}_{\text {org }}$ by several per mil (Wynn, 2007). Here, instead of analyzing the $\delta^{13} \mathrm{C}_{\text {org }}$ from bulk paleosol samples, we adopt a slightly different method of analyzing only the organic matters enclosed in the pedogenic carbonate nodules. We argue that organic matter enclosed in the carbonate nodules should have a better chance of preserving their original isotopic signals from aerobic decomposition. More importantly, exposed paleosols are often contaminated by 
modern plants, fungi, and soil bacteria, therefore, analyzing only the organic matters enclosed in the carbonate nodules could greatly reduce the risk of sampling the modern organic contaminations.

Paleosol organic carbon isotope $\left(\delta^{13} \mathrm{C}_{\text {org }}\right)$ analysis was performed on all 21 samples at the Environmental Isotope Laboratory of the University of Arizona. Pedogenic carbonate nodules were carefully washed using distilled water and dried in room temperature before crushing into powders using mortar and pestle. Carbonates were removed by adding sulfurous acid $\left(\mathrm{H}_{2} \mathrm{SO}_{3}\right)$ to the sample in a silver-foil combustion capsule. Every 24 hours two drops of acid were added to the samples and then they were dried overnight at $55^{\circ} \mathrm{C}$. After visible bubbles were no longer generated by the addition of acid, two more drops of acid were added to ensure complete removal of carbonate and the samples were dried. The foil capsule was then closed and placed in a tin capsule for combustion. $\delta^{13} \mathrm{C}_{\mathrm{org}}$ was measured on a continuous-flow gas-ratio mass spectrometer (Finnigan Delta PlusXL). Samples were combusted using an elemental analyzer (Costech) coupled to the mass spectrometer. Standardization is based on acetanilide for elemental concentrations, and NBS-22 and USGS-24 for $\delta^{13}$ C. Precision is better than \pm 0.08 for $\delta^{13} \mathrm{C}(1 \mathrm{~s})$, based on repeated analysis of internal standards.

Alternatively, the $\delta^{13} \mathrm{C}_{\text {org }}$ values can be estimated using an empirical equation relating the $\delta^{13} \mathrm{C}_{\mathrm{a}}$ to the $\delta^{13} \mathrm{C}$ of paleosol organic matter: $\delta^{13} \mathrm{C}_{\mathrm{a}}=\left(\delta^{13} \mathrm{C}_{\text {org }}+18.67\right) / 1.1$ (3) (Arens et al., 2000), where the $\delta^{13} \mathrm{C}_{\mathrm{a}}$ can be derived from the coeval $\delta^{13} \mathrm{C}$ of planktonic foraminifera, assuming a $-7.5 \%$ isotopic equilibrium fractionation between ocean and atmospheric $\mathrm{CO}_{2}$ under the high ocean temperatures $\left(>30^{\circ} \mathrm{C}\right)$ of mid-Cretaceous (Forster et al., 2007; Lynch-Stieglitz et al., 1995). The $\delta^{13} \mathrm{C}$ of planktonic forams can be derived from the Deep Sea Drilling Project (Huber et al., 1995) and the Tanzania Drilling Project (MacLeod et al., 2013), showing $\delta^{13} \mathrm{C}$ of 
planktonic forams $\sim 2 \%$. The equation (3) thus yields a $\delta^{13} \mathrm{C}_{\mathrm{org}}$ value of $-24.7 \%$. This value is consistent with our measured $\delta^{13} \mathrm{C}_{\text {org }}$ from paleosol record ( -26 to $\sim-24 \%$ ) and $\delta^{13} \mathrm{C}$ values of $\sim-25$ to $-23 \%$ measured from the C-T terrestrial organic matter from northern Japan (Hasegawa, 2003). Together, the consistence of $\delta^{13} \mathrm{C}_{\mathrm{org}}$ estimates derived from various proxies suggest the organic matters in the Markam paleosol preserved an original signal of $\delta^{13} \mathrm{C}_{\text {org }}$ without significant ${ }^{13} \mathrm{C}$-enrichment by microbial decay. Therefore, the coexisting paleosol $\delta^{13} \mathrm{C}_{\text {org }}$ is adopted as $\delta^{13} \mathrm{C}_{\mathrm{r}}$ in the $p \mathrm{CO}_{2}$ equation (2). Value for $\delta^{13} \mathrm{C}_{\mathrm{a}}$ is further calculated using equation (2): $\delta^{13} \mathrm{C}_{\mathrm{a}}=\left(\delta^{13} \mathrm{C}_{\text {org }}+18.67\right) / 1.1$.

\section{Results}

\section{Mineralogical analysis, petrographic analysis and isotopic screening}

Computer-aided mineral identification using X'Pert High Score software indicates that carbonate nodule samples all consist of calcite, quartz, and minor clay minerals. Calcite is the dominant component of the samples and the only carbonate species present, as inferred from maximum XRD peaks varying between $29.20^{\circ}$ and $29.502^{\circ} \theta$, and a d-spacing of 3.03 to $3.06 \AA$ (Table 1), which is almost identical to published laboratory standards for calcium carbonate (29.40 $2^{\circ} \theta$ and $3.04 \AA$, respectively) (Swanson et al., 1953). Elemental analysis on carbonate mineral phases reveals low Mg/Ca and Sr/Ca ratios (<0.01) (Table 1) (Graham et al., 2005). 
Table 1. Sample mineralogy as determined by $\mathrm{XRD}, \mathrm{Mg} / \mathrm{Ca}$, and $\mathrm{Sr} / \mathrm{Ca}$ ratios

\begin{tabular}{|c|c|c|c|c|c|c|c|}
\hline \multirow{2}{*}{$\begin{array}{c}\text { Sample } \\
\text { ID }\end{array}$} & \multirow{2}{*}{$\begin{array}{c}\text { Stratigraphic } \\
\text { Position } \\
(\mathrm{m})\end{array}$} & \multicolumn{4}{|c|}{ XRD results } & \multicolumn{2}{|c|}{ Elemental results } \\
\hline & & $\begin{array}{c}\text { Number } \\
\text { of } \\
\text { counts }\end{array}$ & $\begin{array}{c}100 \% \\
2^{\circ} \theta\end{array}$ & $\begin{array}{c}100 \% \\
\text { d-spacing } \\
(\AA) \\
\end{array}$ & Main component & $\mathrm{Mg} / \mathrm{Ca}$ & $\mathrm{Sr} / \mathrm{Ca}$ \\
\hline \multicolumn{8}{|c|}{ Section A-A' } \\
\hline MK6325 & 281 & 72892 & 29.364 & 3.04170 & Calcite, Quartz & 0.0054 & 0.0008 \\
\hline MK6322 & 263 & 83277 & 29.380 & 3.04016 & Calcite, Quartz & 0.0047 & 0.0006 \\
\hline MK6321 & 250 & 78943 & 29.436 & 3.03444 & Calcite, Quartz & 0.0050 & 0.0012 \\
\hline MK6319 & 215 & 61613 & 29.422 & 3.03588 & Calcite, Quartz & 0.0048 & 0.0009 \\
\hline MK6318 & 195 & 85589 & 29.431 & 3.03497 & Calcite, Quartz & 0.0047 & 0.0004 \\
\hline MK6317 & 192 & 52815 & 29.414 & 3.03667 & Calcite, Quartz & 0.0064 & 0.0006 \\
\hline MK6316 & 140 & 37980 & 29.203 & 3.05812 & Calcite, Quartz & 0.0062 & 0.0007 \\
\hline MK6315 & 107 & 78881 & 29.416 & 3.03644 & Calcite, Quartz & 0.0048 & 0.0004 \\
\hline MK6312 & 84 & 66107 & 29.393 & 3.03884 & Calcite, Quartz & 0.0070 & 0.0006 \\
\hline MK6311 & 59 & 49812 & 29.412 & 3.03690 & Calcite, Quartz & 0.0077 & 0.0010 \\
\hline MK639 & 29 & 71606 & 29.436 & 3.03444 & Calcite, Quartz & 0.0066 & 0.0006 \\
\hline MK638 & 15 & 80815 & 29.440 & 3.03407 & Calcite, Quartz & 0.0072 & 0.0009 \\
\hline \multicolumn{8}{|c|}{ Section C-C' } \\
\hline MK6230 & 310 & 11670 & 29.475 & 3.03051 & Calcite, Quartz & N/A & N/A \\
\hline MK6228 & 300 & 11272 & 29.477 & 3.03036 & Calcite, Quartz & N/A & N/A \\
\hline MK6227 & 234 & 11663 & 29.468 & 3.03125 & Calcite, Quartz & N/A & N/A \\
\hline MK6226 & 192 & 10956 & 29.481 & 3.02988 & Calcite, Quartz & N/A & N/A \\
\hline MK6223 & 162 & 10615 & 29.502 & 3.02778 & Calcite, Quartz & N/A & N/A \\
\hline MK6222 & 112 & 9994 & 29.474 & 3.03059 & Calcite, Quartz & N/A & N/A \\
\hline MK6220 & 100 & 11314 & 29.466 & 3.03142 & Calcite, Quartz & N/A & N/A \\
\hline MK6221 & 72 & 11327 & 29.485 & 3.02949 & Calcite, Quartz & N/A & N/A \\
\hline MK6218 & 35 & 7719 & 29.498 & 3.02824 & Calcite, Quartz & N/A & N/A \\
\hline N/A: data & t availab & & & & & & \\
\hline
\end{tabular}

Thin-section petrographic examination shows that carbonate nodules are dominated by red-brown micritic calcite groundmass occasionally overprinted by dark-brown soil mottling (Fig. 4). Detrital siliciclastic quartz grains are common in thin-sections (Fig. 4) and no detrital carbonate grains are observed. Sparry calcite cement typically occurs in isolated vugs/veins (Figs. 4E, F) and makes up $<5 \%$ of total carbonate phases. The sparry calcite has distinct crystal 
boundaries from the surrounding micritic groundmass and displays rhombic crystal shape and lamellar twinning in plane-polarized light (Figs. 4E, F). Organic matters are preserved in some carbonate nodules, occur as dark brown-colored opaque matrix.

Stable isotopic screening of soil nodules with both micritic and sparry textures from 11 paleosol horizons (sampling position within stratigraphic sections shown in Table 2) reveals that the two types of calcite have very similar isotopic values within same nodules (Table 2). Average differences of $\delta^{13} \mathrm{C}$ and $\delta^{18} \mathrm{O}$ values between micritic and co-existing sparry calcite are $0.25 \%$ (range $=0.01-0.63 \% o$ ) and $0.24 \%$ (range $=0.03-0.68 \%$ o), respectively, whereas the stable isotopic values of both micrite and sparry calcite can vary as much as $\sim 3 \%$ (for $\delta^{18} \mathrm{O}$ ) and $\sim 2.5 \%$ (for $\delta^{13} \mathrm{C}$ ) among different paleosol horizons (Table 2). 

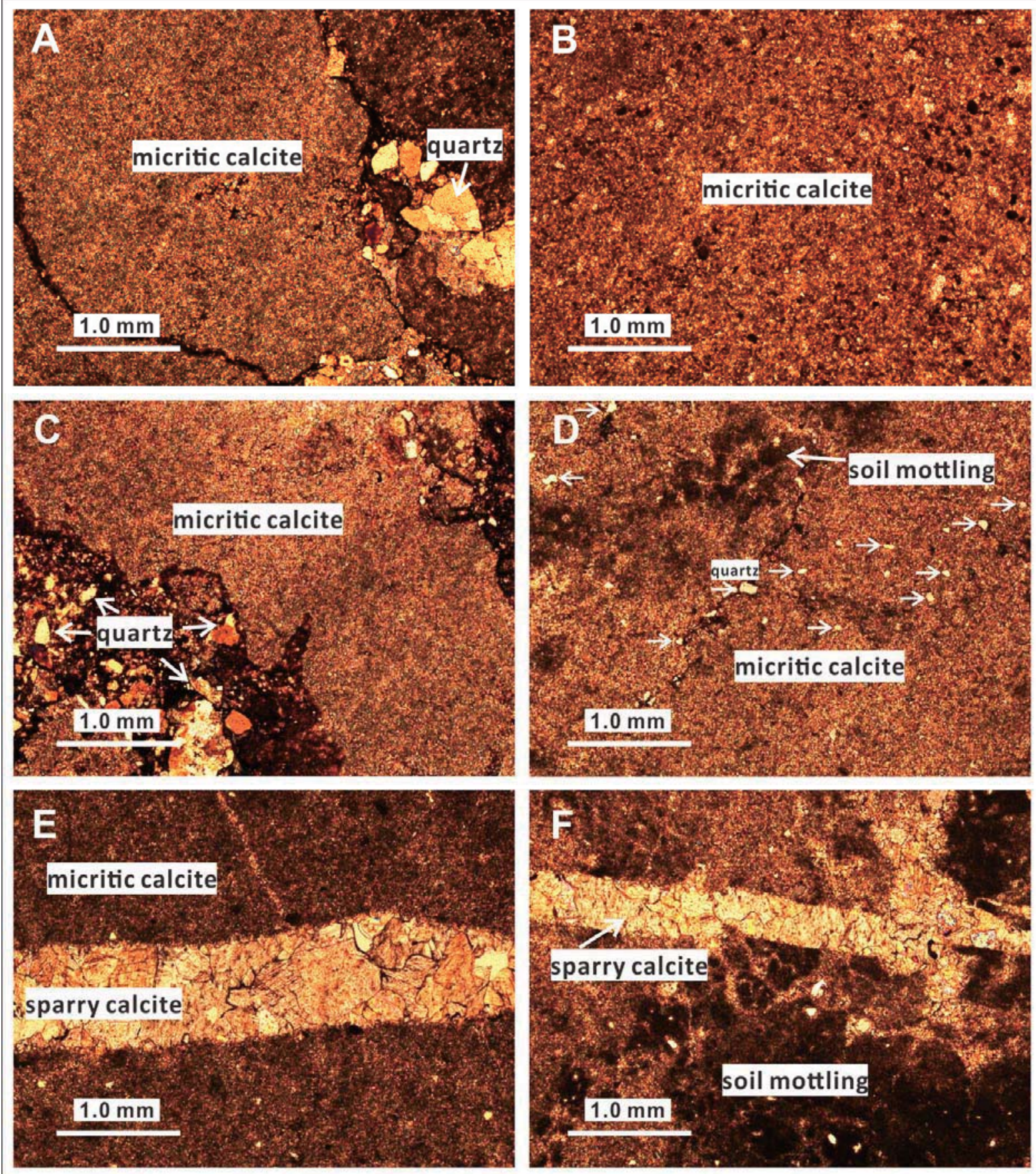

Figure 4. Photomicrographs of studied carbonate nodules. (A-D) Photomicrographs taken

under polarized lights showing dominant micritic calcite groundmass with variable amounts of detrital quartz grains and soil color mottling feature. (E, F) Photomicrographs of carbonate cement showing crack-filling spar calcite (under polarized lights). Only the areas with homogeneous micritic textures were sampled for clumped isotopic analyses. 
Table 2. Isotopic values of micro-sampled micritic and co-existing sparry clacite

\begin{tabular}{|c|c|c|c|c|c|c|c|c|c|c|c|c|}
\hline Nodule Sample ID & \multicolumn{2}{|c|}{ Nodule 1} & \multicolumn{2}{|c|}{ Nodule 2} & \multicolumn{2}{|c|}{ Nodule 3} & \multicolumn{2}{|c|}{ Nodule 4} & \multicolumn{2}{|c|}{ Nodule 5} & \multicolumn{2}{|c|}{ Nodule 6} \\
\hline $\begin{array}{l}\text { Sampling } \\
\text { Position }\end{array}$ & \multicolumn{2}{|c|}{$15 \mathrm{~m}$} & \multicolumn{2}{|c|}{$29 \mathrm{~m}$} & \multicolumn{2}{|c|}{$84 \mathrm{~m}$} & \multicolumn{2}{|c|}{$112 \mathrm{~m}$} & \multicolumn{2}{|c|}{$150 \mathrm{~m}$} & \multicolumn{2}{|c|}{$162 \mathrm{~m}$} \\
\hline $\begin{array}{c}\delta^{13} \mathrm{C}, \delta^{18} \mathrm{O} \\
(\%, \text { VPDB) } \\
\text { micrite } 1\end{array}$ & -8.5 & -10.5 & -8.6 & -10.9 & -8.9 & -10.1 & -9.0 & -10.5 & -7.2 & -10.0 & -7.8 & -9.6 \\
\hline $\begin{array}{c}\delta^{13} \mathrm{C}, \delta^{18} \mathrm{O} \\
(\%, \text { VPDB) } \\
\text { micrite } 2\end{array}$ & -8.7 & -10.3 & N/A & N/A & -8.7 & -9.5 & -9.2 & -10.5 & -7.6 & -9.8 & -7.0 & -9.8 \\
\hline $\begin{array}{c}\delta^{13} \mathrm{C}, \delta^{18} \mathrm{O} \\
(\%, \text { VPDB }) \\
\text { spar }\end{array}$ & -9.0 & -10.4 & -8.3 & -10.8 & -9.3 & -10.2 & -9.1 & -10.6 & -7.8 & -9.5 & -7.6 & -9.1 \\
\hline
\end{tabular}

\begin{tabular}{l}
\hline Note: Detailed sampling spots within each nodule are shown in Fig. A.1. \\
\hline Continue...
\end{tabular}

\begin{tabular}{|c|c|c|c|c|c|c|c|c|c|}
\hline \multicolumn{2}{|c|}{ Nodule 7} & \multicolumn{2}{|c|}{ Nodule 8} & \multicolumn{2}{|c|}{ Nodule 9} & \multicolumn{2}{|c|}{ Nodule 10} & \multicolumn{2}{|c|}{ Nodule 11} \\
\hline \multicolumn{2}{|c|}{$215 \mathrm{~m}$} & \multicolumn{2}{|c|}{$234 \mathrm{~m}$} & \multicolumn{2}{|c|}{$250 \mathrm{~m}$} & \multicolumn{2}{|c|}{$265 \mathrm{~m}$} & \multicolumn{2}{|c|}{$300 \mathrm{~m}$} \\
\hline-8.3 & -12.1 & -9.0 & -12.3 & -9.0 & -12.5 & -9.2 & -12.3 & -8.6 & -11.5 \\
\hline-8.3 & -12.0 & -9.0 & -12.0 & -9.1 & -12.3 & -9.2 & -12.2 & -8.6 & -11.7 \\
\hline-8.4 & -11.8 & -9.4 & -11.9 & -8.8 & -12.3 & -9.2 & -12.4 & -8.6 & -11.6 \\
\hline
\end{tabular}




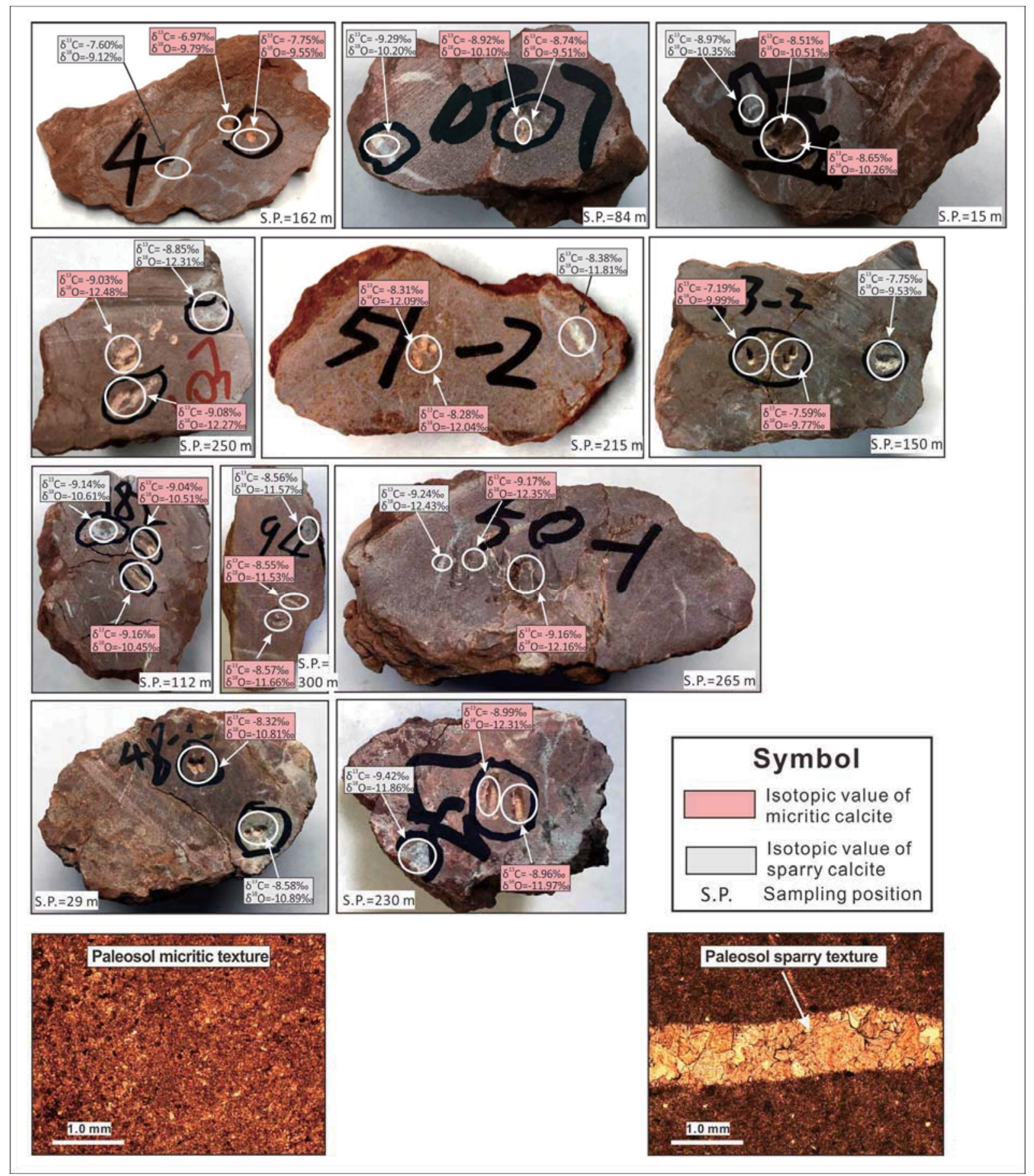

Figure A.1. Photographs of micro-sampled carbonate nodules, showing micro-sampling spots within each nodule and corresponding isotopic values. 


\section{Clumped-isotope thermometry and atmospheric $\mathrm{pCO}_{2}$ reconstruction}

A summary of isotopic results, including $\delta^{18} \mathrm{O}_{\text {carbonate }}, \delta^{13} \mathrm{C}_{\text {carbonate }}, \delta^{13} \mathrm{C}_{\mathrm{org}}, \Delta_{47}$ and calculated $\Delta_{47}-\mathrm{T}, \delta^{18} \mathrm{O}_{\text {water }}$ and $p \mathrm{CO}_{2}$ values, are provided in Tables 3 and 4 . Details of clumped isotope analysis, including standards measured over the period of sample analysis are listed in Supplementary Table $1 . \Delta_{47}$ values for all samples ranged from $0.609 \%$ o to $0.677 \%$ (absolute reference scale), with external precision (1 standard error for replicates of a sample) varying from $0.009 \%$ o to $0.018 \%$.

The range of $\Delta_{47}$ values translate to carbonate formation temperatures of $27-48{ }^{\circ} \mathrm{C}$, with external errors in $\Delta_{47}$-temperature $\left(\Delta_{47}\right.$ - $\left.\mathrm{T}\right)$ values averaging $\pm \sim 4{ }^{\circ} \mathrm{C}$ and ranging from $\pm \sim 2{ }^{\circ} \mathrm{C}$ to $\pm \sim 5{ }^{\circ} \mathrm{C}$ (Table 3). Carbonate $\delta^{13} \mathrm{C}$ and $\delta^{18} \mathrm{O}$ values vary between $-9.39 \%$ and $-7.66 \%$ VPDB, and between $-12.65 \%$ and $-9.26 \%$ VPDB, respectively, with calculated $\delta^{18} \mathrm{O}_{\text {water }}$ values range from $\sim-3 \%$ o to $\sim-8 \%$ VSMOW (Table 3). Estimated $\mathrm{pCO}_{2}$ levels range from $\sim 500$ to $\sim 1200$ ppmV with parameters used for calculations listed in Table 4. The combined soil temperature, $\delta^{18} \mathrm{O}_{\text {water }}$ and $p \mathrm{CO}_{2}$ reconstructions for the $\mathrm{C}-\mathrm{T}$ sequence are characterized by several marked changes that are used to subdivide this succession into 3 intervals: an interval that generally corresponds to the Cenomanian (0-150 m height in the composite section), a transition interval that contains the C-T boundary (150-230 m height in the composite section), and an interval that contains the Turonian (230-320 m height in the composite section) (Fig. 5). Mean values and associated standard error ( 1 s.e.) of soil temperature, $\delta^{18} \mathrm{O}_{\text {water }}$ and $p \mathrm{CO}_{2}$ were calculated for each intervals (Tables 3 and 4).

Average $\Delta_{47}-\mathrm{T}$ increases from $35 \pm 1.2{ }^{\circ} \mathrm{C}$ in the Cenomanian to $46 \pm 1.1^{\circ} \mathrm{C}$ during the C-T transition, and then decrease slightly back to $44 \pm 0.5^{\circ} \mathrm{C}$ in the Turonian (Fig. 5A; Table 3). Average $\delta^{18} \mathrm{O}_{\text {water }}$ values show a similar trend, increasing up-section from $-6.7 \pm 0.3 \%$ o 
Table 3. Stable isotope data including clumped isotope results. Temperatures calculated using the inorganic calibration of Tripati et al. (2015), generated on the same instrument.

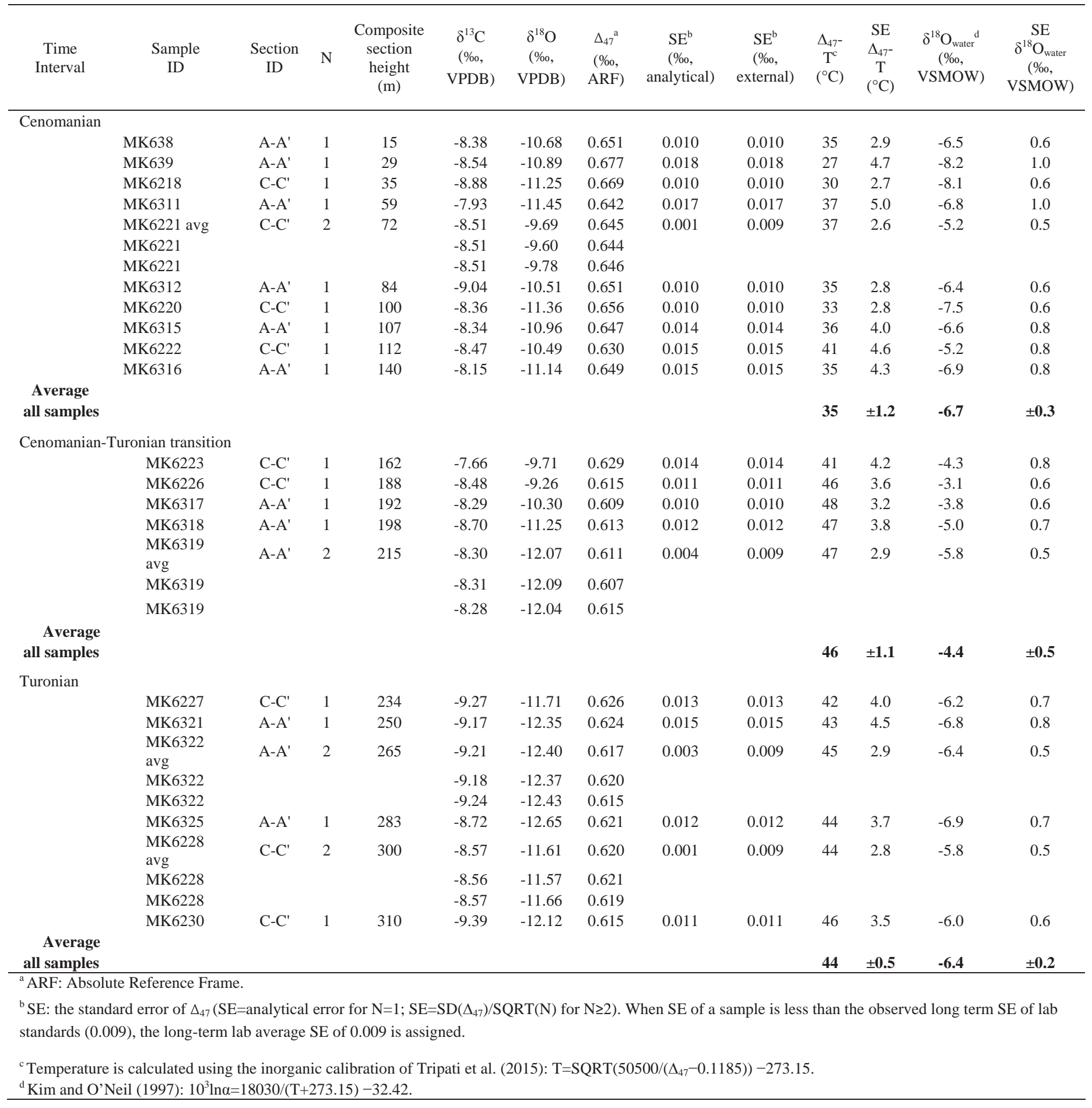


Table 4. Parameters used for $p \mathrm{CO}_{2}$ estimation.

\begin{tabular}{|c|c|c|c|c|c|c|c|c|c|c|c|c|c|c|c|c|c|c|}
\hline \multirow[b]{2}{*}{$\begin{array}{c}\text { Time } \\
\text { Interval }\end{array}$} & \multirow[b]{2}{*}{$\begin{array}{l}\text { Sample } \\
\text { ID }\end{array}$} & \multirow[b]{2}{*}{$\begin{array}{l}\text { Section } \\
\text { ID }\end{array}$} & \multirow{2}{*}{$\begin{array}{l}\text { Composite } \\
\text { section } \\
\text { height } \\
(\mathrm{m})\end{array}$} & \multirow{2}{*}{$\begin{array}{c}\delta^{13} \mathrm{C}_{\mathrm{c}}^{\mathrm{a}} \\
(\%, \\
\text { VPDB })\end{array}$} & \multicolumn{6}{|c|}{$\begin{array}{l}\text { Carbon isotopic } \\
\text { fractionation factor }\end{array}$} & \multirow{2}{*}{$\begin{array}{c}\delta^{13} \mathrm{C}_{\mathrm{s}}^{\mathrm{c}} \\
(\% o, \\
\text { VPDB })\end{array}$} & \multicolumn{3}{|c|}{$\begin{array}{l}\text { soil-respired } \mathrm{CO}^{2} \\
(\mathrm{ppm})\end{array}$} & \multirow{2}{*}{$\begin{array}{c}\delta^{13} \mathrm{C}_{\mathrm{org}}^{\mathrm{e}} \\
(\% o \\
\text { VPDB })\end{array}$} & \multirow[b]{2}{*}{$\begin{array}{c}\delta^{13} \mathrm{C}_{\mathrm{a}}^{\mathrm{f}} \\
(\% o \\
\text { VPDB })\end{array}$} & \multirow{2}{*}{\multicolumn{2}{|c|}{$\begin{array}{l}\mathrm{pCO}_{2}{ }^{\mathrm{g}} \\
(\mathrm{ppm})\end{array}$}} \\
\hline & & & & & \multicolumn{6}{|c|}{$\begin{array}{c}\Delta_{47}-\mathrm{T} \\
\left({ }^{\circ} \mathrm{C}\right)\end{array}$} & & $\begin{array}{c}\text { Burial } \\
\text { depth } \\
(\mathrm{km})\end{array}$ & $\begin{array}{c}\text { Depth } \\
\text { to Bk } \\
\text { horizon } \\
(\mathrm{cm})\end{array}$ & $\begin{array}{c}\mathrm{S}_{(\mathrm{z})}{ }^{\mathrm{d}} \\
(\mathrm{ppm})\end{array}$ & & & & \\
\hline \multicolumn{19}{|c|}{ Cenomanian } \\
\hline & MK638 & A-A' & 15 & -8.38 & 35 & \pm & 2.9 & 7.8 & \pm & 0.4 & -16.17 & 0.7 & $21-27^{\mathrm{h}}$ & $1154-1342$ & -25.91 & -6.58 & 718 & 125 \\
\hline & MK639 & A-A' & 29 & -8.54 & 27 & \pm & 4.7 & 8.7 & \pm & 0.6 & -17.22 & 0.7 & $21-27$ & $1154-1342$ & ${ }^{\mathrm{i}}-26.24$ & -6.88 & 587 & 147 \\
\hline & MK6218 & C-C' & 35 & -8.88 & 30 & \pm & 2.7 & 8.4 & \pm & 0.3 & -17.30 & 0.7 & $27-32$ & $1342-1531$ & -26.24 & -6.88 & 649 & 108 \\
\hline & MK6311 & A-A' & 59 & -7.93 & 37 & \pm & 5.0 & 7.5 & \pm & 0.6 & -15.42 & 0.7 & $21-27$ & $1154-1342$ & -24.86 & -5.63 & 675 & 171 \\
\hline & MK6221 & C-C' & 72 & -8.51 & 37 & \pm & 2.6 & 7.6 & \pm & 0.3 & -16.11 & 0.7 & $21-27^{\mathrm{h}}$ & $1154-1342$ & -26.46 & -7.08 & 849 & 137 \\
\hline & MK6312 & A-A' & 84 & -9.04 & 35 & \pm & 2.8 & 7.8 & \pm & 0.4 & -16.86 & 0.7 & $21-27$ & $1154-1342$ & -25.18 & -5.92 & 466 & 89 \\
\hline & MK6220 & C-C' & 100 & -8.36 & 33 & \pm & 2.8 & 8.0 & \pm & 0.3 & -16.34 & 0.7 & $16-21$ & $965-1154$ & -25.20 & -5.94 & 472 & 92 \\
\hline & MK6315 & A-A' & 107 & -8.34 & 36 & \pm & 4.0 & 7.7 & \pm & 0.5 & -16.02 & 0.7 & $21-27$ & $1154-1342$ & -24.93 & -5.69 & 570 & 129 \\
\hline & MK6222 & $\mathrm{C}-\mathrm{C}^{\prime}$ & 112 & -8.47 & 41 & \pm & 4.6 & 7.0 & \pm & 0.6 & -15.52 & 0.7 & $16-21$ & $965-1154$ & -25.21 & -5.94 & 613 & 153 \\
\hline & MK6316 & A-A' & 140 & -8.15 & 35 & \pm & 1.2 & 7.7 & \pm & 0.5 & -15.88 & 0.7 & $11-16$ & $776-965$ & -25.81 & -6.49 & 539 & 136 \\
\hline \multicolumn{19}{|l|}{ Average } \\
\hline all sampl & & & & & & & & & & & & & & & & & \multicolumn{2}{|r|}{$614 \pm 37^{j}$} \\
\hline \multicolumn{19}{|c|}{ Cenomanian-Turonian transition } \\
\hline & MK6223 & C-C' & 162 & -7.66 & 41 & \pm & 4.2 & 7.0 & \pm & 0.5 & -14.66 & 0.6 & $16-21^{\mathrm{h}}$ & $965-1154$ & ${ }^{\mathrm{i}}-25.81$ & -6.49 & 907 & 203 \\
\hline & MK6226 & $\mathrm{C}-\mathrm{C}^{\prime}$ & 188 & -8.29 & 46 & \pm & 3.6 & 6.5 & \pm & 0.4 & -14.78 & 0.6 & $16-21$ & $965-1154$ & -26.22 & -6.86 & 969 & 196 \\
\hline & MK6317 & A-A' & 192 & -8.29 & 48 & \pm & 3.2 & 6.3 & \pm & 0.4 & -14.54 & 0.6 & $21-27$ & $1140-1326$ & -26.16 & -6.81 & \#\#\# & 212 \\
\hline & MK6318 & A-A' & 198 & -8.70 & 47 & \pm & 3.8 & 6.4 & \pm & 0.5 & -15.09 & 0.6 & $16-21$ & $965-1154$ & -25.50 & -6.21 & 741 & 159 \\
\hline & MK6319 & $A-A^{\prime}$ & 215 & -8.30 & 47 & \pm & 2.9 & 6.3 & \pm & 0.4 & -14.64 & 0.6 & $11-16$ & $776-965$ & -25.92 & -6.59 & 764 & 152 \\
\hline \multicolumn{19}{|l|}{ Average } \\
\hline all samp & & & & & & & & & & & & & & & & & \multicolumn{2}{|r|}{$915 \pm 82^{j}$} \\
\hline \multicolumn{19}{|l|}{ Turonian } \\
\hline & MK6227 & $\mathrm{C}-\mathrm{C}^{\prime}$ & 234 & -9.27 & 42 & \pm & 4.0 & 6.9 & \pm & 0.5 & -16.17 & 0.5 & $11-16$ & 776-965 & -26.37 & -7.00 & 569 & 136 \\
\hline & MK6321 & A-A' & 250 & -9.17 & 43 & \pm & 4.5 & 6.8 & \pm & 0.6 & -16.00 & 0.5 & $21-27$ & $1140-1326$ & -26.05 & -6.71 & 785 & 177 \\
\hline & MK6322 & A-A' & 265 & -9.22 & 45 & \pm & 2.9 & 6.6 & \pm & 0.3 & -15.78 & 0.5 & $26-31$ & $1326-1511$ & -25.47 & -6.18 & 806 & 132 \\
\hline & MK6325 & $A-A^{\prime}$ & 283 & -8.72 & 44 & \pm & 3.7 & 6.7 & \pm & 0.5 & -15.42 & 0.5 & $21-26$ & $1140-1326$ & -25.75 & -6.44 & 845 & 168 \\
\hline & MK6228 & C-C $C^{\prime}$ & 300 & -8.57 & 44 & \pm & 2.8 & 6.7 & \pm & 0.3 & -15.25 & 0.5 & $26-31$ & 13261511 & -25.49 & -6.20 & 942 & 150 \\
\hline & MK6230 & C-C' & 310 & -9.39 & 46 & \pm & 3.5 & 6.5 & \pm & 0.4 & -15.88 & 0.5 & $21-27$ & $1140-1326$ & -25.56 & -6.26 & 703 & 137 \\
\hline \multicolumn{19}{|l|}{ Average } \\
\hline all sampl & & & & & & & & & & & & & & & & & & $775 \pm 52^{j}$ \\
\hline${ }^{\mathrm{a}} \delta^{13} \mathrm{C}_{\mathrm{c}}: \delta^{1}$ & of soil carl & & & & & & & & & & & & & & & & & \\
\hline $\begin{array}{l}{ }^{\mathrm{b}} \alpha_{\text {Calcite-Co }} \\
{ }^{\mathrm{c}} \delta^{13} \mathrm{C}_{\mathrm{s}}: \delta^{1}\end{array}$ & $\begin{array}{l}\text { Fractionatio } \\
\text { of soil } \mathrm{CO}_{2}\end{array}$ & $\mathrm{n}$ factor $\mathrm{f}$ & carbon betw & calcite & & 2. Equ & tion: & Calcite- & & 1.98 & $12 \mathrm{~T}(\mathrm{R}$ & lanek et & ., 1992). & & & & & \\
\hline $\begin{array}{l}{ }^{\mathrm{d}} \mathrm{S}_{(\mathrm{z})}: \text { Soil } \\
\text { standard }\end{array}$ & $\begin{array}{l}\mathrm{CO}_{2} \text { concentr } \\
\text { mpaction for }\end{array}$ & $\begin{array}{l}\text { ation. } S_{(z)} \\
\text { mula (She }\end{array}$ & $\begin{array}{l}\text { alculated usin } \\
\text { don and Retal }\end{array}$ & $\begin{array}{l}\text { a revised } \\
\text { ack, } 2001\end{array}$ & 1 & pth co & relatio & n equi & & Breec & r and Ret & lack, 201 & 4). Reporte & Bk-depth has b & en correc & for soil & mpacti & ion using a \\
\hline${ }^{\mathrm{e}} \delta^{13} \mathrm{C}_{\mathrm{org}}:$ & $\mathrm{C}$ of soil ors & anic matt & & & & & & & & & & & & & & & & \\
\hline${ }^{\mathrm{f}} \delta^{13} \mathrm{C}_{\mathrm{a}}: \delta^{1}$ & of atmosph & eric $\mathrm{CO}_{2}$ & & & & & & & & & & & & & & & & \\
\hline${ }^{\mathrm{g}}$ Errors of & stimated $p C$ & $\mathrm{O}_{2}$ reflect & ncertainties in & oil carbo & te fo & rming & emper & atures & $\Delta_{47^{-}}$ & ) and & (z) determ & nation. & & & & & & \\
\hline${ }^{\mathrm{h}} \mathrm{Bk}$-deptl & were not be & able to ac & urately determ & ned due to & erosic & on and & the de & th val & es w & ere ad & pted from & neasurem & nt made fr & $\mathrm{n}$ the nearest p & eosol prof & & & \\
\hline${ }^{\mathrm{i}}$ The coex & ting $\delta^{13} \mathrm{C}_{\mathrm{org}}$ & alues wer & not be able to & determine & due $t$ & o low & organi & carbc & & tent, a & $d$ their $\delta^{13}$ & org value & were adop & drom $\delta^{13} C_{\text {org }}$ & easured fr & $\mathrm{m}$ the nea & st pale & osol layers. \\
\hline
\end{tabular}


in the Cenomanian to $-4.4 \pm 0.5 \%$ at the $\mathrm{C}-\mathrm{T}$ transition, and then decreasing back to $-6.4 \pm$ $0.2 \%$ in the Turonian. Note that within the transition interval, individual $\delta^{18} \mathrm{O}_{\text {water }}$ values fluctuate considerably, ranging from $\sim-3 \%$ o to $\sim-6 \%$ o (Fig. 5B; Table 3). The estimated atmospheric $\mathrm{CO}_{2}$ concentrations from paleosols show an average value of $614 \pm 37 \mathrm{ppm}$ in the Cenomanian, followed by a large increase by $>40 \%$ in the transition stage with the average value reaching $915 \pm 82 \mathrm{ppm}$ (Fig. 5C; Table 4). The rise in $p \mathrm{CO}_{2}$ level is coincident with a large increase of average soil temperatures (from $\sim 35^{\circ} \mathrm{C}$ to $\sim 46{ }^{\circ} \mathrm{C}$ ). During the Turonian, the average value of reconstructed atmospheric $\mathrm{CO}_{2}$ decreases to $775 \pm 52 \mathrm{ppm}$ (Fig. 5C; Table 4).

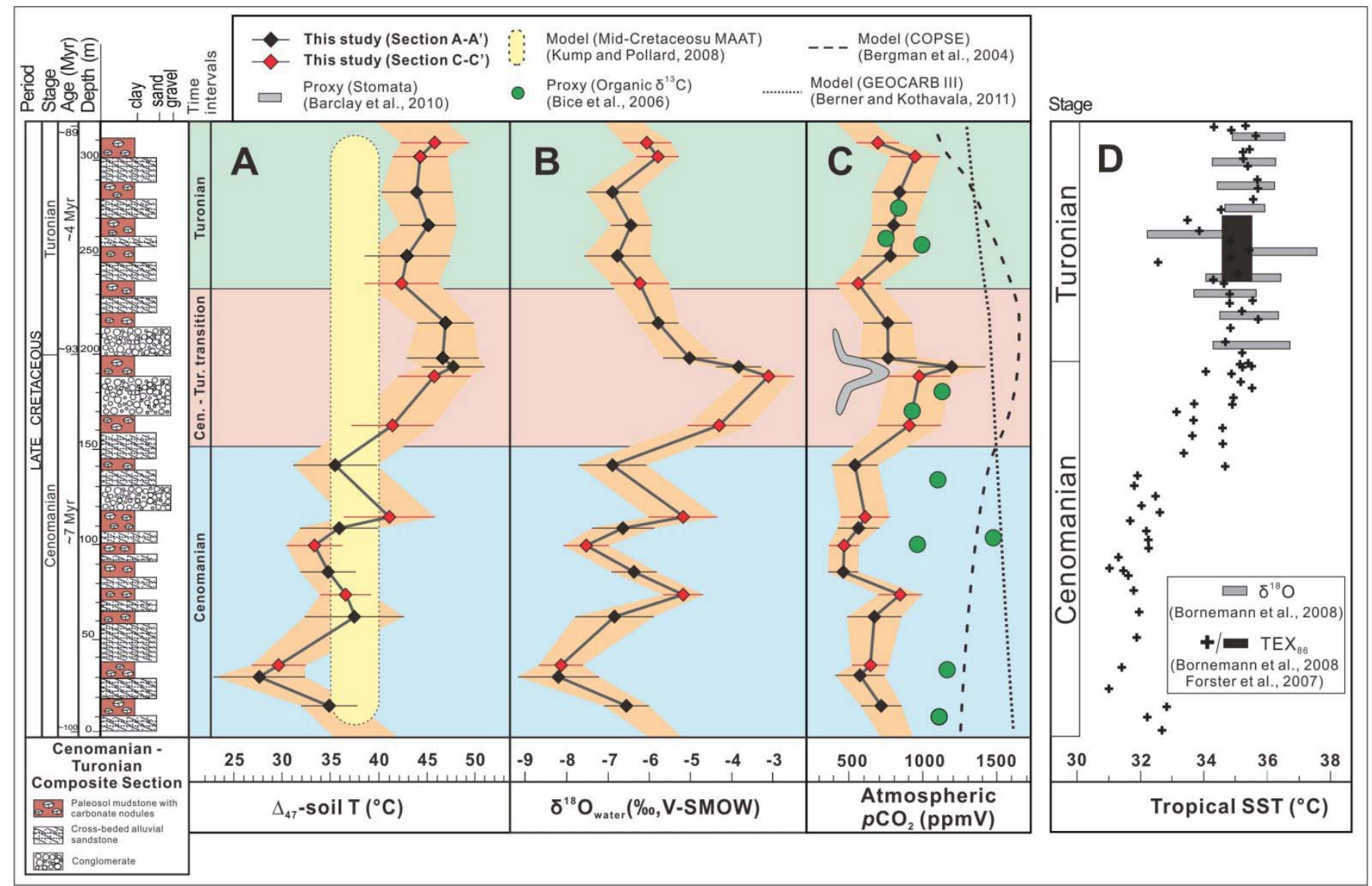

Figure 5. $\Delta_{47}$-temperature, $\delta^{18} \mathrm{O}_{\text {water }}$, and atmospheric $\mathrm{CO}_{2}\left(p \mathrm{CO}_{2}\right)$ estimated from Markam paleosols. Note that the black and red diamonds represent samples from two different sections (A-A' and section C-C', respectively), with associated error bars. Samples were assigned as 
either: Cenomanian (blue shading); Cenomanian-Turonian transition (red shading); or Turonian (green shading). (A) $\Delta_{47}$-temperature estimates are based on the inorganic calibration of Tripati et al. (2015), generated on the same instrument, plotted with simulated mean annual surface-air temperature (MAAT) of southeastern Tibet during mid-Cretaceous (Kump and Pollard, 2008). (B) Calculated oxygen isotope values of soil water $\left(\delta^{18} \mathrm{O}_{\text {water }}\right)$. (C) Estimated $p \mathrm{CO}_{2}$ levels from Markam paleosol record, plotted with $p \mathrm{CO}_{2}$ estimates from previous studies: 1. $p \mathrm{CO}_{2}$ estimates from geochemical models (Bergman et al., 2004; Berner and Kothavala, 2001); 2. $p \mathrm{CO}_{2}$ estimates from stomatal density (Barclay et al., 2010) and carbon isotope of marine sediments (Bice et al., 2006). (D) Cenomanian-Turonian (C-T) tropical sea surface temperature estimates from organic geochemical proxy (TEX ${ }_{86}$ ) (Bornemann et al., 2008; Forster et al., 2007) and oxygen isotope ratios of planktonic foraminifera based on assumed values for water $\delta^{18} \mathrm{O}$ (Bornemann et al., 2008).

\section{Discussion and Implication}

\section{Evaluating potential diagenetic effects}

Diagenetic alternation is an important issue that must be examined before meaningful interpretation of any isotopic results. The burial and thermal history of the Late Cretaceous Nanxin Formation derived from fluid inclusion and vitrinite reflectivity studies suggest a maximum burial temperature less than $80^{\circ} \mathrm{C}$, with vitrinite reflectivity values of organic matter less than 0.5 (Chen et al., 2010). This temperature estimate is consistent with geological observation that the Cretaceous red beds are poorly compacted rocks that form the youngest and shallowest sedimentary unit in the Markam region, except some very scattered, localized Eocene deposits (Pan et al., 2004). Henkes et al. (2014) suggest that $\Delta_{47}$ value of calcite should not be affected by solid-state $\mathrm{C}-\mathrm{O}$ bound reordering if temperatures were below $100{ }^{\circ} \mathrm{C}$ over timescales of up to $10^{8}$ years. Thus, the low burial temperatures provide the first evidence that carbonate nodules in the Nanxin Formation was unlikely experienced major solid-state resetting during 
burial.

Petrographic observations show that the studied soil carbonates are dominated by micritic texture with minor sparry calcite cement filing veins and vugs (Fig. 4). Although materials used for clumped isotope analysis are sampled from micritic calcite, the large amounts of material ( $\sim 10 \mathrm{mg}$ for each analysis) necessary for clumped isotope measurements makes it likely that some calcite cement was probably included. Therefore, it is important to determine the diagenetic history of cement and evaluate its potential influence on clumped isotope analysis. Carbonate cement can form during early diagenetic, mesodiagenetic and late diagenetic phases (Choquette and Pray, 1970). Early diagenetic cement forms at the surface or shallow subsurface environments and therefore may primarily record the original surface climate and environmental conditions (e.g., surface temperature and $\delta^{18} \mathrm{O}_{\text {water }}$ ). In contrast, mesodiagenetic and late diagenetic cements occur during deep burial and post-burial uplift and erosion stages, respectively, and are precipitated from fluids that may have different isotopic compositions from the original surface waters (Brand and Veizer, 1981). $\delta^{13} \mathrm{C}$ and $\delta^{18} \mathrm{O}$ analysis of micrite and coexisting sparry cement of soil nodules from 11 horizons reveals that micritic calcite and sparry cement have very similar isotopic values (Table 2), with average differences of $\delta^{13} \mathrm{C}$ and $\delta^{18} \mathrm{O}$ values between micrite and co-existing sparry cement of $0.25 \%$ (range $=0.01-0.63 \%$ o $)$ and of $0.24 \%$ o (range $=0.03-0.68 \%$ o), respectively (Table 2 ), whereas isotopic values of nodules (for both micrite and sparry calcite) from different horizons can vary from $6.97 \%$ to $9.42 \%$ for $\delta^{13} \mathrm{C}$ and from $9.12 \%$ o to $12.48 \%$ ofor $\delta^{18} \mathrm{O}$ (Table 2). The similar isotopic values between micrite and co-existing sparry cement suggests that carbonate cements in our studied paleosols were most likely formed during early diagenesis in phreatic zones, forming rhombic spars filling vugs and cracks within soil nodules (Tucker and Wright, 2009). Although mesodiagenesis during deep 
burial could also homogenize isotopic values between micritic and sparry calcite phases, such process was unlikely to happen given relatively shallow burial depth as indicated by basin thermal history study (Chen et al., 2010), and relatively low $\Delta_{47}-\mathrm{T}\left(\sim 30^{\circ} \mathrm{C}\right)$ from the deepest part of the studied section (Fig. 5A), indicating maximum burial temperature was unlikely exceeded $100{ }^{\circ} \mathrm{C}$ for a prolonged period of time (Henkes et al., 2014). The carbonate cement could also formed during late diagenesis after erosion and exhumation exposed the Cretaceous rocks to the surface. Regional tectonic study suggests that major deformation in the study area occurred in early Cenozoic during Indo-Asian collision (Studnicki-Gizbert et al., 2008). If the carbonate cements were precipitated during late diagenesis, we would expect to see: 1) difference of isotopic values between micrite and sparry cement as climate conditions during mid-Cretaceous and early Cenozoic were likely very different (e.g., Pagani et al., 2014; Zachos et al., 2008) and 2) similar isotopic values of carbonate cement among different soil horizons because late diagensis would likely to happen synchronously throughout the C-T strata, given that the sampled sections are only 300 meters long. However, isotopic analysis of micrite and co-existing sparry cement shows that the two phases have very similar isotopic values within in the same soil horizons, whereas isotopic values of calcite cement varies significantly among different paleosol profiles ( $>3 \%$ for $\delta^{18} \mathrm{O}$ and $>2 \%$ for $\delta^{13} \mathrm{C}$ ) (Table 2). These observations suggest that carbonate cements in our studied nodules were mainly formed during early diagenesis, and mesodiagenesis and late diagenesis have limited influence on soil nodules. Therefore, $\delta^{18} \mathrm{O}$ and $\Delta_{47}$-T values recorded by sparry cement primarily reflect near-surface environmental conditions similar to those recorded by micritic calcite.

Finally, we observed no systematic $\Delta_{47}$-T versus depth relationship in the studied sections. The $\Delta_{47}-\mathrm{T}$ trends we observed indicate that soil temperatures do not increase with burial 
depth. On the contrary, it generally decreases with depth (Fig. 5A). For example, the three samples from the base of the Cenomanian strata (MK6218, MK638, MK629) exhibit $\Delta_{47-T}$ 30$35^{\circ} \mathrm{C}$, cooler than all the other values observed above, whereas, the highest $\Delta_{47}$ - T occurs in the middle part of the section. It is also unlikely that the observed temperature trend was due to modification by hydrothermal fluids given the complete absence of major intrusive mineral veins or nearby igneous bodies, relatively simple structure of the study area, and poorly-compacted nature of the Cretaceous sedimentary rocks.

In summary, burial history, thermal maturity, petrography, and isotopic screening all indicate that our carbonate samples did not experience deep burial and associated postdepositional diagenesis, which favors the preservation of primary climate signals of soil formation without solid-state $\mathrm{C}-\mathrm{O}$ bond reordering.

\section{Evaluation of $\Delta_{47}$-derived soil temperatures}

The calculated $\Delta_{47}-\mathrm{T}$ values show that more than half of the carbonate nodules exhibit growth temperatures in excess of $40{ }^{\circ} \mathrm{C}$ (Table 3 ) that, if interpreted as a primary climate signal, indicate very high ground temperatures in the tropics at a site located at $\sim 15^{\circ} \mathrm{N}$ during the midCretaceous. Studies have shown that in most cases soil carbonates form under temperatures considerably warmer than mean annual temperature (e.g., Passey et al., 2010; Quade et al., 2013), concentrated in the summer months of the year during drought seasons, when soil temperature exceeds mean annual temperature by more than $15^{\circ} \mathrm{C}$ (e.g., Breecker et al., 2009). If representative, that means only hot summer temperatures will be recorded in soil carbonates, especially in arid regions where soil dewatering commonly happens in the summer months (Breecker et al., 2009; Hough et al., 2014). Clumped isotope study of modern soil carbonates 
from various places and climate regimes reveal that $40{ }^{\circ} \mathrm{C}$ is the upper limit for most modern soil carbonates formed at soil depth $>25 \mathrm{~cm}$ (Quade et al., 2013), and $\Delta_{47}-\mathrm{T}>40{ }^{\circ} \mathrm{C}$ indicates either substantially warmer climate regimes compared to the present, or diagenetic signals produced by resetting during deep burial (Quade et al., 2013), the latter of which we have been able to preclude based on assessment of the burial history and observations of the sedimentology and geochemistry, as discussed above.

Cretaceous climate reconstructions indicate southeastern Tibet was located within a widespread evaporite zone near the equatorial region (at $\sim 15^{\circ} \mathrm{N}$ ) during the mid-Cretaceous (Hay and Floegel, 2012). The evaporite zone was characterized by increased aridity and evaporation during the C-T 'super-greenhouse' interval (Hay and Floegel, 2012), consistent with our isotopic data showing high soil carbonate forming temperatures and enriched $\delta^{18} \mathrm{O}_{\text {water }}$ values indicating strong soil evaporation at the C-T boundary (Fig. 5B). In the field, the inferred aridity is supported by relatively shallow Bk-depth even after burial decompaction (decompacted Bkdepth ranges from 10 to $31 \mathrm{~cm}$; average $=21 \mathrm{~cm}$ ) (Table 4), indicating mean annual precipitation of $350 \mathrm{~mm}$ (Retallack, 2005). Climate model (i.e., GENESIS v. 3.0) simulation shows that mean annual surface-air temperature (MAAT) in our study area had reached $35-40{ }^{\circ} \mathrm{C}$ during mid-Cretaceous ( 100 Ma) (Kump and Pollard, 2008), suggesting that the warm-month surfaceair temperature (WAAT) may had reached well above $40{ }^{\circ} \mathrm{C}$. Quade et al. (2013) show that soil carbonate typically forms in warm months when soil temperature exceeds MAAT by $10-15{ }^{\circ} \mathrm{C}$ due to timing of calcite precipitation based on study of Holocene soils. If representative, that means soil nodules in our study site should record warm-month temperatures of $\sim 45-55{ }^{\circ} \mathrm{C}, 10$ $15^{\circ} \mathrm{C}$ higher than the MAAT, though the more equable mid-Cretaceous climate (e.g., Pagani et al., 2014) was probably characterized by reduced seasonalities (i.e., smaller difference between 
MAAT and WAAT). Furthermore, direct solar heating can elevate deep soil temperatures by more than $5{ }^{\circ} \mathrm{C}$, especially in arid settings where plant shadings are rare (Quade et al., 2013). We also note that even conservative estimate of SSTs during the Turonian in the tropical Atlantic Ocean can reach up to $36{ }^{\circ} \mathrm{C}$ (Forster et al., 2007), whereas estimates derived from oxygen isotope and $\mathrm{Mg} / \mathrm{Ca}$ ratios from well-preserved planktonic foraminifera suggest the tropical Atlantic Ocean SSTs may reach up to $40^{\circ} \mathrm{C}$ (Bice et al., 2006). If these high SSTs are representative, then it is very likely that the tropical ground temperature was even higher especially during summer season when solar radiation is at its strongest.

Therefore, we argue that the observed high $\Delta_{47}-\mathrm{T}$ values $\left(>40{ }^{\circ} \mathrm{C}\right)$ from the late Cenomanian and Turonian paleosol nodules are plausible because these soil nodules formed in an arid environmental setting during one of the warmest periods in Cretaceous, with limited influenced from late-stage diagenesis and solid-state reordering of soil carbonate.

\section{Reconstruction of Cenomanian-Turonian ground temperatures and atmospheric $\mathrm{pCO}_{2}$ level}

Reconstructed $\Delta_{47}$-soil temperature record shows that the Cenomanian interval is the 'coolest' part of our studied section and contains some of the lowest observed soil temperatures from the C-T interval (e.g., $27{ }^{\circ} \mathrm{C}$ at $29 \mathrm{~m}$ and $30^{\circ} \mathrm{C}$ at $35 \mathrm{~m}$ composite section heights) (Fig. 5A). Within the Cenomanian interval, several additional temperature trends can be observed. One sample from the lowest paleosol horizon displays $\Delta_{47}$-T value of $35 \pm 3{ }^{\circ} \mathrm{C}$. The value decreases up-section to $\sim 27-30^{\circ} \mathrm{C}$, and then increases back to $\sim 37^{\circ} \mathrm{C}$ by the middle of the Cenomanian section (Fig. 5A). Onset of the C-T transition is marked by a rise in soil temperatures from $\sim 37{ }^{\circ} \mathrm{C}$ to $>45{ }^{\circ} \mathrm{C}$; this rise coincides with a $2 \%$ increase of $\delta^{18} \mathrm{O}_{\text {water }}$ values from $-6 \%$ to $-4 \%$ (Fig. 5B). Average soil temperature then reached a thermal maximum at $46 \pm$ 
$1.1{ }^{\circ} \mathrm{C}$ which was maintained throughout the transition interval. A temperature drop of $\sim 5^{\circ} \mathrm{C}$ in the lower Turonian is observed in both sections and marks the termination of the C-T transition thermal maximum (Fig. 5A). Although the Turonian was a little cooler than the C-T transition, average soil temperature is maintained at $44 \pm 0.5^{\circ} \mathrm{C}$, consistent with the reconstruction that indicates Turonian climate was remarkably hot and stable (MacLeod et al., 2013).

Average values of $\delta^{18} \mathrm{O}_{\text {water }}$ are relatively constant throughout the section at $\sim 6 \%$, except at the C-T transition where a large positive excursion is observed. Average $\delta^{18} \mathrm{O}_{\text {water }}$ values increase dramatically from $\sim-6 \%$ to $\sim-4 \%$ (Fig. $5 \mathrm{~B}$ ). The positive excursion is coincident with the onset of the C-T thermal maximum. A cross-plot of $\Delta_{47}-\mathrm{T}$ and $\delta^{18} \mathrm{O}_{\text {water }}$ also reveals a broad correlation between the two factors (Fig. 6A), suggesting enhanced soil evaporation associated with rising soil temperatures. The very high $\Delta_{47}$-temperatures (average $=46 \pm 1.1^{\circ} \mathrm{C}$ ) and the positive excursion of $\delta^{18} \mathrm{O}_{\text {water }}$ at the $\mathrm{C}-\mathrm{T}$ transition interval are likely related to two factors: 1 ) extreme high surface temperature associated with the C-T thermal maximum; and 2) intense soil evaporation associated with increased aridity. In comparison, pedogenic carbonate from the Turonian interval also record relatively high formation temperature (average $=44 \pm 0.5^{\circ} \mathrm{C}$ ), but the $\delta^{18} \mathrm{O}_{\text {water }}$ values are much less enriched as compared to the samples from the $\mathrm{C}$ - $\mathrm{T}$ transition, which indicates reduced soil evaporation and thus reduced aridity during Turonian.

The Cenomanian to early Turonian warming trend evident in this low-latitude $\left(\sim 15^{\circ} \mathrm{N}\right)$ terrestrial soil temperature record (Fig. 5A) can be correlated to contemporaneous paleoclimate reconstructions. Tropical sea surface temperature (SST) estimates derived from the $\mathrm{TEX}_{86}$ proxy show a gradual warming trend during the Cenomanian, followed by a thermal maximum at the C-T boundary (Forster et al., 2007) (Fig. 5D), similar to what we observed. The same trend can also be inferred from $\delta^{18} \mathrm{O}$ values of well-preserved marine fossils from mid- and high-latitude 
regions (Huber et al., 1995; Huber et al., 2002; Jenkyns et al., 2004), which both show a stepwise temperature rise through the Cenomanian, succeeded by a temperature maximum at the C-T boundary.

Our reconstructed $\mathrm{pCO}_{2}$ levels are $\sim 500-1200 \mathrm{ppmV}$, lower than the values derived from geochemical models such as GEOCARB III (Berner and Kothavala, 2001) and COPSE (Bergman et al., 2004) (Fig. 5C). The trend of increasing $p \mathrm{CO}_{2}$ level at the $\mathrm{C}$-T transition seen in our reconstruction is also observed in the COPSE model (Bergman et al., 2004), although it is not seen in the GEOCARB III model (Berner and Kothavala, 2001) results, which is likely due to its coarse temporal resolution $(\sim 10 \mathrm{Ma})$. Our estimated $p \mathrm{CO}_{2}$ values generally overlap estimates derived from marine organic matter (Bice et al., 2006), and the short-term record estimated using stomata density (Barclay et al., 2010) (Fig. 5C). Barclay et al. (2010) observed a 20\% rise of atmospheric $\mathrm{CO}_{2}$ concentrations at the $\mathrm{C}-\mathrm{T}$ boundary, succeeded by a $26 \%$ decrease of $p \mathrm{CO}_{2}$ levels associated with extensive carbon burial during OAE 2 ( 93.5 Ma). In our paleosol record, a position excursion of $\mathrm{pCO}_{2}$ levels at the C-T boundary is also observed, with $p \mathrm{CO}_{2}$ levels increased to $>1000 \mathrm{ppmV}$ at the $\mathrm{C}-\mathrm{T}$ transition, followed by a $\sim 20 \%$ drop right after the transition (Fig. 5C). The decrease of $\mathrm{pCO}_{2}$ concentration may associated with extensive carbon sequestration during OAE 2 (e.g., Barclay et al., 2010), though a better geochronological constraint is needed (e.g., U-Pb dating of pedogenic carbonate) (Rasbury and Cole, 2009) to further confirm the exact position of the C-T boundary in our studied sections.

\section{Implication for mid-Cretaceous regional climate sensitive over tropics}

Proxy data have been used to determine climate sensitivity $\left(\Delta T_{2 \mathrm{X}}\right)$ (Hansen et al., 2008; 
Royer, 2010), which is the equilibrium temperature response to a doubling of $p \mathrm{CO}_{2}$. Estimates from proxy data that consider fast feedback processes average $\sim 3^{\circ} \mathrm{C}$ (Solomon, 2007). In contrast, higher estimates of $\sim 6^{\circ} \mathrm{C}$ are estimated if we consider "deep-time" records where the response is also impacted by slow feedbacks in the Earth system such as changes in surface albedo associated with vegetation migration and landscape evolution, ice sheet retreat, and the release of greenhouse gases from ocean sediments, tundra, and soils (Joos, 2015; Kump and Pollard, 2008; Stocker et al., 2013; Wang et al., 2014).

A cross-plot of our reconstructed mid-Cretaceous surface temperatures and $p \mathrm{CO}_{2}$ levels reveals a broad positive correlation $\left(\mathrm{r}^{2}=0.41\right)$ (Fig. 6B; solid black line). The increase of $p \mathrm{CO}_{2}$ levels from $\sim 500$ to $\sim 1000 \mathrm{ppmV}$ is accompanied by an average soil temperature rise from $\sim 35$ to $\sim 45^{\circ} \mathrm{C}$, which corresponds to a $\Delta T_{2 \mathrm{X}} \sim 10{ }^{\circ} \mathrm{C}$ (Fig. $6 \mathrm{~B}$ ). We note a similarly high estimate of climate sensitivity derived using our $p \mathrm{CO}_{2}$ estimates and published tropical Cenomanian and Turonian SST dataset (Bornemann et al., 2008; Forster et al., 2007). The increase of average tropical SSTs from $\sim 31$ to $\sim 35^{\circ} \mathrm{C}$ (Bornemann et al., 2008; Forster et al., 2007) is coincident with a rise of average $p \mathrm{CO}_{2}$ levels from $614 \pm 37$ to $775 \pm 52 \mathrm{ppmV}$ (Fig. 6B, dashed blue line), similar to the best-fit correlation between temperature and $\mathrm{pCO}_{2}$ values determined from the paleosol record. Our estimated regional climate sensitivity in mid-Cretaceous is significantly higher than modern day values of $\sim 1.5-4.5^{\circ} \mathrm{C}$ per $p \mathrm{CO}_{2}$ doubling as suggested by the Intergovernmental Panel on Climate Change (Solomon, 2007), consistent with the view that Earth's climate response to increasing atmospheric $\mathrm{CO}_{2}$ concentration was significantly enhanced in greenhouse world (e.g., Pagani et al., 2014; Royer, 2010).

Substantially higher climate sensitivities in mid-Cretaceous time may reflect carbon cycle feedbacks that operate under 'super-greenhouse' conditions, in part arising from the impacts of 
enhanced water transport to the high-latitudes. The combined effects of moisture and temperature on terrestrial carbon cycling in high-latitude and tropical regions, and changes in fire regimes, may result in high carbon emissions (Joos, 2015; Landry et al., 2015; Stocker et al., 2013). The production of methane in sediments, and the transfer of carbon from the ocean to the atmosphere, might also be greatly accelerated under 'super-greenhouse' conditions (Kort et al., 2012).

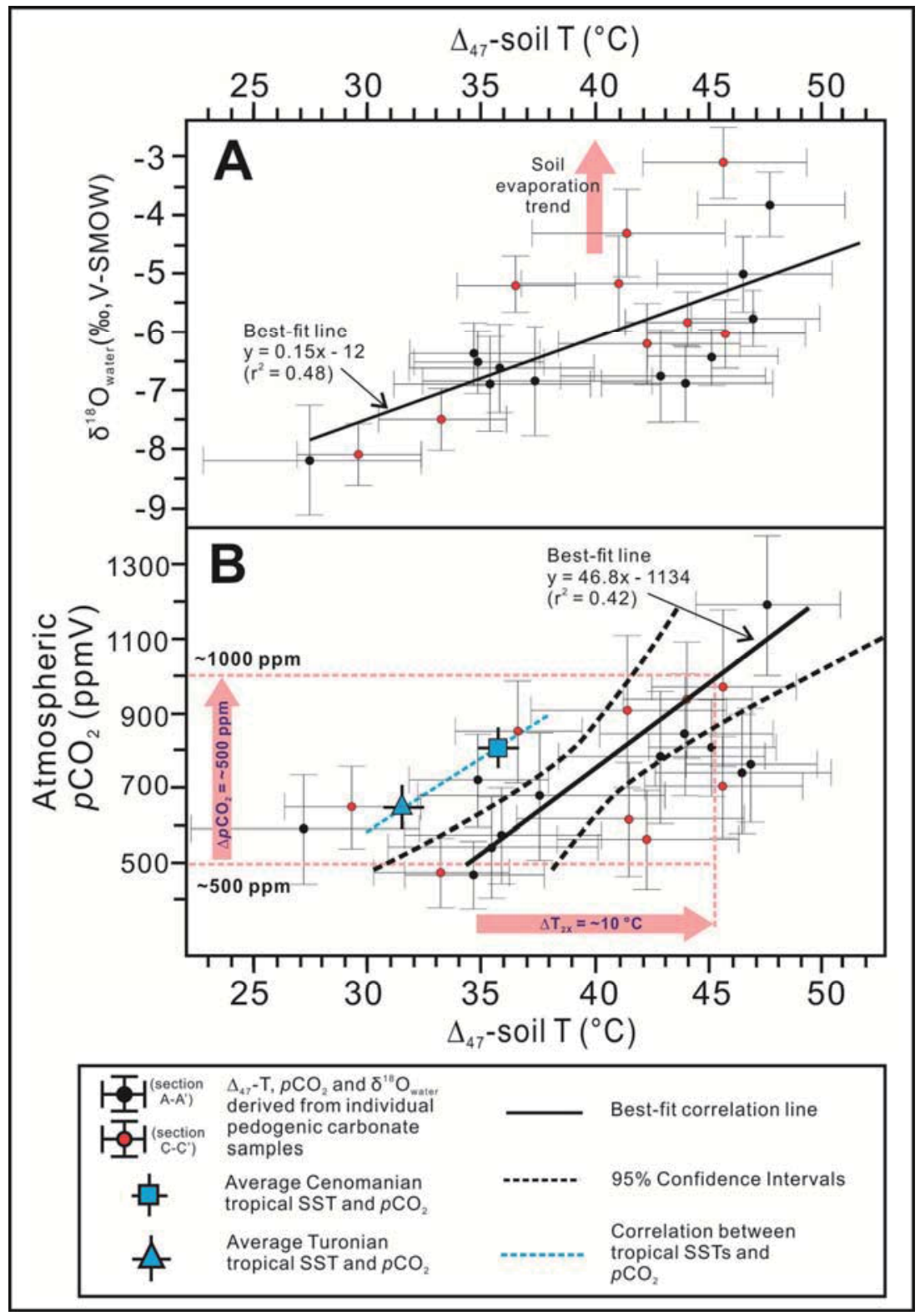


Figure 6. Constraints on regional climate sensitivity for the mid-Cretaceous. Black and red dots indicate individual samples from sections A-A' and C-C', respectively. Regression lines are generated based on all paleosol samples. (A) Cross-plot of $\Delta_{47}-\mathrm{T}$ and $\delta^{18} \mathrm{O}_{\text {water. Solid black line }}$ represents best-fit correlation between $\Delta_{47}-\mathrm{T}$ and $\mathrm{pCO}_{2}$. Points plotted above the line likely represent effects of soil evaporation. (B) Cross-plot of $\Delta_{47}$-temperatures $\left(\Delta_{47}-\mathrm{T}\right)$ and estimated $p \mathrm{CO}_{2}$ levels. Solid black line represents best-fit correlation between $\Delta_{47}$-T and $p \mathrm{CO}_{2}$, which corresponds to an average climate sensitivity $\left(\Delta \mathrm{T}_{2 \mathrm{X}}\right)$ of $\sim 10{ }^{\circ} \mathrm{C}$ per $\mathrm{CO} 2$ doubling. Dashed black lines mark the $95 \%$ confidence Intervals. Dashed blue line is based on the correlation between tropical sea surface temperature (Bornemann et al., 2008; Forster et al., 2007) and $\mathrm{pCO}_{2}$ derived from Markam paleosol record. 


\section{References}

Arens, N. C., Hope Jahren, A., and Amundson, R., 2000, Can C3 plants faithfully record the carbon isotopic composition of atmospheric carbon dioxide?: Paleobiology, v. 26, no. 1, p. $137-164$.

Arthur, M., Dean, W., and Schlanger, S., 1985, Variations in the global carbon cycle during the Cretaceous related to climate, volcanism, and changes in atmospheric CO2: The Carbon Cycle and Atmospheric CO: Natural Variations Archean to Present, p. 504-529.

Barclay, R. S., McElwain, J. C., and Sageman, B. B., 2010, Carbon sequestration activated by a volcanic CO2 pulse during Ocean Anoxic Event 2: Nature Geoscience, v. 3, no. 3, p. 205-208.

Bergman, N. M., Lenton, T. M., and Watson, A. J., 2004, COPSE: a new model of biogeochemical cycling over Phanerozoic time: American Journal of Science, v. 304, no. 5, p. 397-437.

Berner, R. A., and Kothavala, Z., 2001, GEOCARB III: a revised model of atmospheric CO2 over Phanerozoic time: American Journal of Science, v. 301, no. 2, p. 182-204.

Bice, K., Huber, B., and Norris, R., 2003, Extreme polar warmth during the Cretaceous greenhouse? The paradox of the late Turonian $\delta 18 \mathrm{O}$ record at DSDP Site 511: Paleoceanography, v. 18.

Bice, K. L., Birgel, D., Meyers, P. A., Dahl, K. A., Hinrichs, K. U., and Norris, R. D., 2006, A multiple proxy and model study of Cretaceous upper ocean temperatures and atmospheric CO2 concentrations: Paleoceanography, v. 21, no. 2.

Blakey, R. C., 2008, Gondwana paleogeography from assembly to breakup-A 500 my odyssey: Geological Society of America Special Papers, v. 441, p. 1-28.

Bornemann, A., Norris, R. D., Friedrich, O., Beckmann, B., Schouten, S., Damsté, J. S. S., Vogel, J., Hofmann, P., and Wagner, T., 2008, Isotopic evidence for glaciation during the Cretaceous supergreenhouse: Science, v. 319, no. 5860, p. 189-192.

Brand, U., and Veizer, J., 1981, Chemical diagenesis of a multicomponent carbonate system-2: stable isotopes: Journal of Sedimentary Research, v. 51, no. 3.

Breecker, D., and Retallack, G., 2014, Refining the pedogenic carbonate atmospheric CO 2 proxy and application to Miocene CO 2: Palaeogeography, Palaeoclimatology, Palaeoecology, v. 406, p. 1-8.

Breecker, D., Sharp, Z., and McFadden, L., 2010, Atmospheric CO2 concentrations during ancient greenhouse climates were similar to those predicted for AD 2100: Proceedings of the National Academy of Sciences, v. 107, no. 2, p. 576-580.

Breecker, D., Sharp, Z., and McFadden, L. D., 2009, Seasonal bias in the formation and stable isotopic composition of pedogenic carbonate in modern soils from central New Mexico, USA: Geological Society of America Bulletin, v. 121, no. 3-4, p. 630-640.

Cerling, T., 1999, Stable carbon isotopes in palaeosol carbonates: Palaeoweathering, palaeosurfaces and related continental deposits, p. 43-60.

Chamberlain, C. P., Wan, X., Graham, S. A., Carroll, A. R., Doebbert, A. C., Sageman, B. B., Blisniuk, P., Kent-Corson, M. L., Wang, Z., and Chengshan, W., 2013, Stable isotopic evidence for climate and basin evolution of the Late Cretaceous Songliao basin, China: Palaeogeography, Palaeoclimatology, Palaeoecology, v. 385, p. 106-124. 
Chen, H. H., Wu, Y. \& Xiao, Q. J., 2010, Fluid Inclusion Evidence of Paleo-Oil Reservoirs in Changdu Basin, Tibet: Acta Geologica Sinica, v. 84, no. 10, p. 1457-1469.

Choquette, P. W., and Pray, L. C., 1970, Geologic nomenclature and classification of porosity in sedimentary carbonates: AAPG bulletin, v. 54, no. 2, p. 207-250.

Cotton, J. M., and Sheldon, N. D., 2012, New constraints on using paleosols to reconstruct atmospheric pCO2: Geological Society of America Bulletin, v. 124, no. 9-10, p. 14111423.

Defliese, W. F., Hren, M. T., and Lohmann, K. C., 2015, Compositional and temperature effects of phosphoric acid fractionation on $\triangle 47$ analysis and implications for discrepant calibrations: Chemical Geology, v. 396, p. 51-60.

Dennis, K., Cochran, J., Landman, N., and Schrag, D., 2013, The climate of the Late Cretaceous: New insights from the application of the carbonate clumped isotope thermometer to Western Interior Seaway macrofossil: Earth and Planetary Science Letters, v. 362, p. 5165.

Dennis, K. J., Affek, H. P., Passey, B. H., Schrag, D. P., and Eiler, J. M., 2011, Defining an absolute reference frame for 'clumped'isotope studies of CO 2: Geochimica et Cosmochimica Acta, v. 75, no. 22, p. 7117-7131.

Du, D., Luo, J., and Li, X., 1997, Sedimentary evolution and palaeogeography of the Qamdo Block in Xizang: Lithofacies Palaeogeogr, v. 17, no. 4, p. 1-17.

Eagle, R. A., Risi, C., Mitchell, J. L., Eiler, J. M., Seibt, U., Neelin, J. D., Li, G., and Tripati, A. K., 2013, High regional climate sensitivity over continental China constrained by glacialrecent changes in temperature and the hydrological cycle: Proceedings of the National Academy of Sciences, v. 110, no. 22, p. 8813-8818.

Eiler, J. M., 2007, “Clumped-isotope" geochemistry-The study of naturally-occurring, multiply-substituted isotopologues: Earth and Planetary Science Letters, v. 262, no. 3, p. 309-327.

Eiler, J. M., 2011, Paleoclimate reconstruction using carbonate clumped isotope thermometry: Quaternary Science Reviews, v. 30, no. 25, p. 3575-3588.

Eiler, J. M., and Schauble, E., 2004, 18 O 13 C 16 O in Earth's atmosphere: Geochimica et Cosmochimica Acta, v. 68, no. 23, p. 4767-4777.

Ekart, D. D., Cerling, T. E., Montanez, I. P., and Tabor, N. J., 1999, A 400 million year carbon isotope record of pedogenic carbonate: implications for paleoatmospheric carbon dioxide: American Journal of Science, v. 299, no. 10, p. 805-827.

Fan, M., Hough, B. G., and Passey, B. H., 2014, Middle to late Cenozoic cooling and high topography in the central Rocky Mountains: Constraints from clumped isotope geochemistry: Earth and Planetary Science Letters, v. 408, p. 35-47.

Fletcher, B. J., Brentnall, S. J., Anderson, C. W., Berner, R. A., and Beerling, D. J., 2008, Atmospheric carbon dioxide linked with Mesozoic and early Cenozoic climate change: Nature Geoscience, v. 1, no. 1, p. 43-48.

Forster, A., Schouten, S., Baas, M., and Damsté, J. S. S., 2007, Mid-Cretaceous (AlbianSantonian) sea surface temperature record of the tropical Atlantic Ocean: Geology, v. 35, no. 10, p. 919-922.

Freeman, K. H., and Hayes, J., 1992, Fractionation of carbon isotopes by phytoplankton and estimates of ancient CO2 levels: Global Biogeochemical Cycles, v. 6, no. 2, p. 185-198.

Garzione, C. N., Auerbach, D. J., Smith, J. J.-S., Rosario, J. J., Passey, B. H., Jordan, T. E., and Eiler, J. M., 2014, Clumped isotope evidence for diachronous surface cooling of the 
Altiplano and pulsed surface uplift of the Central Andes: Earth and Planetary Science Letters, v. 393, p. 173-181.

Garzione, C. N., Dettman, D. L., and Horton, B. K., 2004, Carbonate oxygen isotope paleoaltimetry: evaluating the effect of diagenesis on paleoelevation estimates for the Tibetan plateau: Palaeogeography, Palaeoclimatology, Palaeoecology, v. 212, no. 1, p. 119-140.

Ghosh, P., Adkins, J., Affek, H., Balta, B., Guo, W., Schauble, E. A., Schrag, D., and Eiler, J. M., 2006, 13C-180 bonds in carbonate minerals: A new kind of paleothermometer: Geochimica et Cosmochimica Acta, v. 70, no. 6, p. 1439-1456.

Gradstein, F. M., Ogg, J. G., and Smith, A. G., 2004, A geologic time scale 2004, Cambridge University Press.

Graham, S. A., Chamberlain, C. P., Yue, Y., Ritts, B. D., Hanson, A. D., Horton, T. W., Waldbauer, J. R., Poage, M. A., and Feng, X., 2005, Stable isotope records of Cenozoic climate and topography, Tibetan plateau and Tarim basin: American Journal of Science, v. 305, no. 2, p. 101-118.

GSX (Geological Survey of Xizang), 2007, Regional Geology Report of Basu, Gonji, Ranwu and Markam counties.

Hansen, J., Sato, M., Kharecha, P., Beerling, D., Berner, R., Masson-Delmotte, V., Pagani, M., Raymo, M., Royer, D. L., and Zachos, J. C., 2008, Target atmospheric CO2: Where should humanity aim?: arXiv preprint arXiv:0804.1126.

Harries, P. J., and Little, C. T., 1999, The early Toarcian (Early Jurassic) and the CenomanianTuronian (Late Cretaceous) mass extinctions: similarities and contrasts:

Palaeogeography, Palaeoclimatology, Palaeoecology, v. 154, no. 1, p. 39-66.

Hasegawa, T., 2003, Cretaceous terrestrial paleoenvironments of northeastern Asia suggested from carbon isotope stratigraphy: Increased atmospheric pCO 2-induced climate: Journal of Asian Earth Sciences, v. 21, no. 8, p. 849-859.

Hay, W. W., and Floegel, S., 2012, New thoughts about the Cretaceous climate and oceans: Earth-Science Reviews, v. 115, no. 4, p. 262-272.

Henkes, G. A., Passey, B. H., Grossman, E. L., Shenton, B. J., Pérez-Huerta, A., and Yancey, T. E., 2014, Temperature limits for preservation of primary calcite clumped isotope paleotemperatures: Geochimica et cosmochimica acta, v. 139, p. 362-382.

Henkes, G. A., Passey, B. H., Wanamaker, A. D., Grossman, E. L., Ambrose, W. G., and Carroll, M. L., 2013, Carbonate clumped isotope compositions of modern marine mollusk and brachiopod shells: Geochimica et Cosmochimica Acta, v. 106, p. 307-325.

Hough, B. G., Fan, M., and Passey, B. H., 2014, Calibration of the clumped isotope geothermometer in soil carbonate in Wyoming and Nebraska, USA: Implications for paleoelevation and paleoclimate reconstruction: Earth and Planetary Science Letters, v. 391, p. 110-120.

Huang, K., Opdyke, N. D., Li, J., and Peng, X., 1992, Paleomagnetism of Cretaceous rocks from eastern Qiangtang terrane of Tibet: Journal of Geophysical Research: Solid Earth (19782012), v. 97, no. B2, p. 1789-1799.

Huber, B. T., Hodell, D. A., and Hamilton, C. P., 1995, Middle-Late Cretaceous climate of the southern high latitudes: stable isotopic evidence for minimal equator-to-pole thermal gradients: Geological Society of America Bulletin, v. 107, no. 10, p. 1164-1191.

Huber, B. T., Norris, R. D., and MacLeod, K. G., 2002, Deep-sea paleotemperature record of extreme warmth during the Cretaceous: Geology, v. 30, no. 2, p. 123-126. 
Huntington, K. W., Saylor, J., Quade, J., and Hudson, A. M., 2015, High late Miocene-Pliocene elevation of the Zhada Basin, southwestern Tibetan Plateau, from carbonate clumped isotope thermometry: Geological Society of America Bulletin, v. 127, no. 1-2, p. 181199.

Jarvis, I., Lignum, J. S., Gröcke, D. R., Jenkyns, H. C., and Pearce, M. A., 2011, Black shale deposition, atmospheric $\mathrm{CO} 2$ drawdown, and cooling during the Cenomanian-Turonian Oceanic Anoxic Event: Paleoceanography, v. 26, no. 3.

Jenkyns, H. C., 2010, Geochemistry of oceanic anoxic events: Geochemistry, Geophysics, Geosystems, v. 11, no. 3.

Jenkyns, H. C., Forster, A., Schouten, S., and Damsté, J. S. S., 2004, High temperatures in the late Cretaceous Arctic Ocean: Nature, v. 432, no. 7019, p. 888-892.

Joos, F., 2015, Global warming: Growing feedback from ocean carbon to climate: Nature, v. 522, no. 7556, p. 295-296.

Kim, S.-T., and O'Neil, J. R., 1997, Equilibrium and nonequilibrium oxygen isotope effects in synthetic carbonates: Geochimica et Cosmochimica Acta, v. 61, no. 16, p. 3461-3475.

Kort, E., Wofsy, S., Daube, B., Diao, M., Elkins, J., Gao, R., Hintsa, E., Hurst, D., Jimenez, R., and Moore, F., 2012, Atmospheric observations of Arctic Ocean methane emissions up to 82 [deg] north: Nature Geoscience, v. 5, no. 5, p. 318-321.

Kump, L. R., and Pollard, D., 2008, Amplification of Cretaceous warmth by biological cloud feedbacks: Science, v. 320, no. 5873, p. 195-195.

Landry, J.-S., Matthews, H. D., and Ramankutty, N., 2015, A global assessment of the carbon cycle and temperature responses to major changes in future fire regime: Climatic Change, p. 1-14.

Lynch-Stieglitz, J., Stocker, T. F., Broecker, W. S., and Fairbanks, R. G., 1995, The influence of air-sea exchange on the isotopic composition of oceanic carbon: Observations and modeling: Global Biogeochemical Cycles, v. 9, no. 4, p. 653-665.

MacLeod, K. G., Huber, B. T., Berrocoso, Á. J., and Wendler, I., 2013, A stable and hot Turonian without glacial $\delta 180$ excursions is indicated by exquisitely preserved Tanzanian foraminifera: Geology, v. 41, no. 10, p. 1083-1086.

Montanez, I. P., 2013, Modern soil system constraints on reconstructing deep-time atmospheric CO 2: Geochimica et Cosmochimica Acta, v. 101, p. 57-75.

Norris, R. D., Bice, K. L., Magno, E. A., and Wilson, P. A., 2002, Jiggling the tropical thermostat in the Cretaceous hothouse: Geology, v. 30, no. 4, p. 299-302.

Pagani, M., Huber, M., and Sageman, B., 2014, Greenhouse climates, Treatise on Geochemistry, Volume 6, Elsevier Oxford, p. 281-304.

Pan, G. T., Ding, J., Yao, D. S., and Wang, L. Q., 2004, Geological map of Qinghai-Xiang (Tibet) Plateau and adjacent areas: Chengdu Institute of Geology and Mineral Resources, China Geological Survey, scale 1:1,500,000, 6 sheets.

Passey, B. H., Levin, N. E., Cerling, T. E., Brown, F. H., and Eiler, J. M., 2010, Hightemperature environments of human evolution in East Africa based on bond ordering in paleosol carbonates: Proceedings of the National Academy of Sciences, v. 107, no. 25, p. 11245-11249.

Petryshyn, V., Lim, D., Laval, B., Brady, A., Slater, G., and Tripati, A., 2015, Reconstruction of limnology and microbialite formation conditions from carbonate clumped isotope thermometry: Geobiology, v. 13, no. 1, p. 53-67. 
Price, G. D., and Passey, B. H., 2013, Dynamic polar climates in a greenhouse world: Evidence from clumped isotope thermometry of Early Cretaceous belemnites: Geology, v. 41, no. 8, p. 923-926.

Quade, J., Eiler, J., Daeron, M., and Achyuthan, H., 2013, The clumped isotope geothermometer in soil and paleosol carbonate: Geochimica et Cosmochimica Acta, v. 105, p. 92-107.

Rasbury, E. T., and Cole, J. M., 2009, Directly dating geologic events: U-Pb dating of carbonates: Reviews of Geophysics, v. 47, no. 3.

Retallack, G. J., 2005, Pedogenic carbonate proxies for amount and seasonality of precipitation in paleosols: Geology, v. 33, no. 4, p. 333-336.

Retallack, G, J., 2009, Refining a pedogenic-carbonate CO 2 paleobarometer to quantify a middle Miocene greenhouse spike: Palaeogeography, Palaeoclimatology, Palaeoecology, v. 281, no. 1, p. 57-65.

Romanek, C. S., Grossman, E. L., and Morse, J. W., 1992, Carbon isotopic fractionation in synthetic aragonite and calcite: effects of temperature and precipitation rate: Geochimica et Cosmochimica Acta, v. 56, no. 1, p. 419-430.

Royer, D. L., 2010, Fossil soils constrain ancient climate sensitivity: Proceedings of the National Academy of Sciences, v. 107, no. 2, p. 517-518.

Schouten, S., Hopmans, E. C., Forster, A., van Breugel, Y., Kuypers, M. M., and Damsté, J. S. S., 2003, Extremely high sea-surface temperatures at low latitudes during the middle Cretaceous as revealed by archaeal membrane lipids: Geology, v. 31, no. 12, p. 10691072.

Sepkoski Jr, J., 1986, Phanerozoic overview of mass extinction, Patterns and Processes in the History of Life, Springer, p. 277-295.

Shang, F., 2014, Detrital zircon geochronology from the Mesozoic Qamdo (Changdu) basin, southeastern Tibet: Implications for the Paleo- and Meso-Tethys evolution, in 2014 GSA Annual Meeting in Vancouver, British Columbia.

Sheldon, N. D., and Retallack, G. J., 2001, Equation for compaction of paleosols due to burial: Geology, v. 29, no. 3, p. 247-250.

Sheldon, N. D., and Tabor, N. J., 2009, Quantitative paleoenvironmental and paleoclimatic reconstruction using paleosols: Earth-Science Reviews, v. 95, no. 1, p. 1-52.

Snell, K. E., Koch, P. L., Druschke, P., Foreman, B. Z., and Eiler, J. M., 2014, High elevation of the 'Nevadaplano' during the Late Cretaceous: Earth and Planetary Science Letters, v. 386, p. 52-63.

Snell, K. E., Thrasher, B. L., Eiler, J. M., Koch, P. L., Sloan, L. C., and Tabor, N. J., 2013, Hot summers in the Bighorn Basin during the early Paleogene: Geology, v. 41, no. 1, p. 5558.

Solomon, S., 2007, Climate change 2007-the physical science basis: Working group I contribution to the fourth assessment report of the IPCC, Cambridge University Press.

Stocker, B. D., Roth, R., Joos, F., Spahni, R., Steinacher, M., Zaehle, S., Bouwman, L., and Prentice, I. C., 2013, Multiple greenhouse-gas feedbacks from the land biosphere under future climate change scenarios: Nature Climate Change, v. 3, no. 7, p. 666-672.

Studnicki-Gizbert, C., Burchfiel, B., Li, Z., and Chen, Z., 2008, Early Tertiary Gonjo basin, eastern Tibet: Sedimentary and structural record of the early history of India-Asia collision: Geosphere, v. 4, no. 4, p. 713-735. 
Suarez, M., Ludvigson, G., Gonzalez, L., and You, H., Linking Cretaceous Continental Climate Change and Ocean Anoxic Events: Evidence from the Xiagou Formation of Gansu Province, China, in Proceedings AGU Fall Meeting Abstracts2012, Volume 1, p. 01.

Suarez, M. B., and Passey, B. H., 2014, Assessment of the clumped isotope composition of fossil bone carbonate as a recorder of subsurface temperatures: Geochimica et Cosmochimica Acta, v. 140, p. 142-159.

Suarez, M. B., Passey, B. H., and Kaakinen, A., 2011, Paleosol carbonate multiple isotopologue signature of active East Asian summer monsoons during the late Miocene and Pliocene: Geology, v. 39, no. 12, p. 1151-1154.

Swanson, H. E., Tatge, E., and Fuyat, R. K., 1953, Standard X-ray diffraction powder patterns.

Tripati, A. K., Eagle, R. A., Thiagarajan, N., Gagnon, A. C., Bauch, H., Halloran, P. R., and Eiler, J. M., 2010, 13 C-18 O isotope signatures and 'clumped isotope'thermometry in foraminifera and coccoliths: Geochimica et Cosmochimica Acta, v. 74, no. 20, p. 56975717.

Tripati, A. K., Hill, P. S., Eagle, R. A., Mosenfelder, J. L., Tang, J., Schauble, E. A., Eiler, J. M., Zeebe, R. E., Uchikawa, J., and Coplen, T. B., 2015, Beyond temperature: Clumped isotope signatures in dissolved inorganic carbon species and the influence of solution chemistry on carbonate mineral composition: Geochimica et Cosmochimica Acta, v. 166, p. 344-371.

Tucker, M. E., and Wright, V. P., 2009, Carbonate sedimentology, John Wiley \& Sons.

Van Bentum, E., Reichart, G.-J., Forster, A., and Sinninghe Damsté, J. S., 2012, Latitudinal differences in the amplitude of the OAE-2 carbon isotopic excursion: pCO 2 and paleo productivity: Biogeosciences, v. 9, no. 2, p. 717-731.

VanDeVelde, J. H., Bowen, G. J., Passey, B. H., and Bowen, B. B., 2013, Climatic and diagenetic signals in the stable isotope geochemistry of dolomitic paleosols spanning the Paleocene-Eocene boundary: Geochimica et Cosmochimica Acta, v. 109, p. 254-267.

Voigt, S., Gale, A. S., and Flögel, S., 2004, Midlatitude shelf seas in the Cenomanian-Turonian greenhouse world: Temperature evolution and North Atlantic circulation: Paleoceanography, v. 19, no. 4.

Wang, X., Piao, S., Ciais, P., Friedlingstein, P., Myneni, R. B., Cox, P., Heimann, M., Miller, J., Peng, S., and Wang, T., 2014, A two-fold increase of carbon cycle sensitivity to tropical temperature variations: Nature, v. 506, no. 7487, p. 212-215.

Wilson, P. A., Norris, R. D., and Cooper, M. J., 2002, Testing the Cretaceous greenhouse hypothesis using glassy foraminiferal calcite from the core of the Turonian tropics on Demerara Rise: Geology, v. 30, no. 7, p. 607-610.

Wynn, J. G., 2007, Carbon isotope fractionation during decomposition of organic matter in soils and paleosols: implications for paleoecological interpretations of paleosols:

Palaeogeography, Palaeoclimatology, Palaeoecology, v. 251, no. 3, p. 437-448.

Zaarur, S., Olack, G., and Affek, H. P., 2011, Paleo-environmental implication of clumped isotopes in land snail shells: Geochimica et Cosmochimica Acta, v. 75, no. 22, p. 68596869.

Zachos, J. C., Dickens, G. R., and Zeebe, R. E., 2008, An early Cenozoic perspective on greenhouse warming and carbon-cycle dynamics: Nature, v. 451, no. 7176, p. 279-283. 


\section{Acknowledgements}

This work was supported by the National Science Foundation under grants EAR-1119219, EAR1119266, EAR-1352212, EAR-1325054, EAR-0949191 and EAR-1205596, DOE grant DEFG0213ER16402, as well as by the "Laboratoire d'Excellence” LabexMER (ANR-10-LABX19), co-funded by a grant from the French government under the program "Investissements

d'Avenir". We thank A. Priyadarshi, A. Bhattarcharya, A. Warrier from the Tripati Clumped Isotope Lab (Team Star Wars) and Sharma Stable Isotope Lab for their assistance.

\section{Author contributions}

F.S. wrote the paper; A.L.W., F.S. and A.K.T. conceived the project. Isotopic analysis was carried out by F.S., A.K.T., S.S. and R.C. All authors were involved in discussions and commented on the manuscript. 


\title{
Chapter III
}

\section{Low-latitude terrestrial climate of southeastern Tibet revealed through clumped isotope thermometry: Implications for Late Cretaceous elevation history of southeastern Tibet}

\author{
Authors: \\ Fei Shang ${ }^{1}{ }^{*}$, Amy L. Weislogel ${ }^{1}$, Robinson M. Delores ${ }^{2}$, Shikha Sharma ${ }^{1}$, Alexander \\ Farnsworth $^{3,4}$, Daniel Lunt ${ }^{3,4}$, Ruiqian Chen ${ }^{1}$, Jackson T. William ${ }^{2}$, Zhao-lin Qi ${ }^{5}$, Aradhna K. \\ Tripati $^{6,7}$ \\ Corresponding author contact: \\ *E-mail: fshang@mix.wvu.edu \\ Author affiliations: \\ ${ }^{1}$ Department of Geology \& Geography, West Virginia University, Morgantown, West Virginia \\ 26506, USA \\ ${ }^{2}$ Department of Geological Sciences, University of Alabama, Tuscaloosa, Alabama 35487, USA \\ ${ }^{3}$ Organic Geochemistry Unit, School of Chemistry, University of Bristol, Bristol, UK \\ ${ }^{4}$ Cabot Institute, University of Bristol, Bristol, UK
}


${ }^{5}$ Geosciences Department, China University of Geosciences (Beijing), Beijing, China

${ }^{6}$ Department of Earth, Planetary, and Space Sciences, Department of Atmospheric and Oceanic

Sciences, Institute of the Environment and Sustainability, California Nanosystems Institute, University of California, Los Angeles, CA, USA

${ }^{7}$ European Institute of Marine Sciences (IUEM), Université de Brest, UMR6538, Domaines Océaniques, Rue Dumont D’Urville, Plouzané, France

\begin{abstract}
Views range widely on the timing of surface uplift of the Tibetan Plateau to its current height of $\sim 5 \mathrm{~km}$, specifically, whether the current elevation of Tibet developed solely in response to the Cenozoic Indo-Asia collision, or was partially inherited from high topography developed during Mesozoic is unclear. Here, we evaluate the Cretaceous elevation history of southeastern Tibet by studying pedogenic carbonates from an alluvial sequence in the Qamdo basin using clumped isotopes as a paleoaltimetry tool. Climate model simulations using the Cretaceous paleogeographic boundary conditions are also conducted to investigate the impact of global climate change on soil temperatures in our study area.

We examined two stratigraphic sections through the Cenomanian-Santonian strata of the Qamdo basin and find that petrography, burial history and elemental composition of paleosol carbonates are consistent with preservation of original isotopic signatures and minimal influence from solid-state reordering. Average soil temperatures (i.e., $\Delta_{47}$-T) decreased from $44 \pm 1.5^{\circ} \mathrm{C}$ (95\% CI) in the Turonian to $38 \pm 3.5^{\circ} \mathrm{C}(95 \% \mathrm{CI})$ by the Santonian time, coincident with decrease of average $\delta^{18} \mathrm{O}_{\text {water }}$ values from $-6.3 \pm 0.5 \%$ (95\% CI) to $-7.3 \pm 0.5 \%$ (95\% CI). Climate model outputs and tropical sea surface temperature (SST) records both show that global
\end{abstract}


climate during the Turonian-Santonian interval were relatively warm and stable, without evidence of significant global cooling. Together, the observed changes in $\Delta_{47}-\mathrm{T}$ and $\delta^{18} \mathrm{O}_{\text {water }}$ values exhibit a pattern that is consistent with surface elevation changes during Late Cretaceous time. Assuming temperature and isotopic lapse rates of $\sim 6^{\circ} \mathrm{C} / \mathrm{km}$ and $\sim 1 \%$ o $/ \mathrm{km}$, respectively, under the extreme warm Late Cretaceous climate conditions, the observed $\Delta_{47}-\mathrm{T}$ and $\delta^{18} \mathrm{O}_{\text {water }}$ shifts correspond to a positive elevation change of $\sim 1 \mathrm{~km}$ in southeastern Tibet during Late Cretaceous time. This inference is supported by evidence of strontium isotope ratios, structure, and sedimentology. Strontium isotope ratios of pedogenic carbonate increase up-section from 0.7106 to 0.7112 , indicating enhanced weathering of continental source areas. Meanwhile, the development of growth strata and occurrence of thick-bedded conglomerate layers within the Late Cretaceous strata all implying active tectonics during deposition. Together, out data suggest that a moderate topography with elevation $>1.5 \mathrm{~km}$ was probably established by Late Cretaceous time in SE Tibet.

\section{Introduction}

Although it has long been recognized that the Tibetan Plateau is a Cenozoic feature produced by the India-Asia collision initiated 55 million years ago (e.g., Dewey and Burke, 1973; Dewey et al., 1988; Garzanti, 2008; Powell and Conaghan, 1973; Rowley, 1996) ample evidence of pre-Cenozoic crustal shortening and thickening (and by inference, topographic growth) have been documented throughout the Tibet, particularly from Cretaceous geological records (Decelles et al., 2007; England and Searle, 1986; Kapp et al., 2007; Kapp et al., 2003; Kapp et al., 2005; Murphy et al., 1997; Studnicki-Gizbert et al., 2008; Sun et al., 2015; Volkmer et al., 2007). Cretaceous crustal deformation and shortening (Decelles et al., 2007; Kapp et al., 
2007; Kapp et al., 2005; Leier et al., 2007; Murphy et al., 1997; Wang et al., 2008), as well as rapid Cretaceous rock cooling histories (Deng et al., 2012; Hetzel et al., 2011; Reid et al., 2005; Rohrmann et al., 2012; Wang et al., 2014; Wilson and Fowler, 2011; Zhang et al., 2012) are mainly attributed to post-collisional orogenesis associated with the Qiangtang-Lhasa collision and/or crustal thickening due to flat-slab subduction of the Neotethyan ocean beneath the Lhasa block. It has been proposed that high elevations in at least southern Tibet were inherited from a pre-Eocene proto-plateau referred to as the 'Lhasaplano' (Kapp et al., 2007). The hypothesis is supported by sedimentological evidence, where Late Cretaceous deformation has been documented in the northern Lhasa block reflecting early topographic growth in that area (Sun et al., 2015). However, thermochronology data from southeastern (SE) Tibet (e.g., Yidun and Songpan-Ganzi terranes) also reveal episodes of extensive Late Jurassic-Early Cretaceous regional rock cooling, which may related to widespread rock uplift resulted from compressional strain field created by the Lhasa-Qiangtang collision (Tian et al., 2014). If the later study is representative, it suggests SE Tibet may had been an elevated area during Late Cretaceous, and therefore the proposed Cretaceous Tibet 'proto-plateau' or 'Lhasaplano' may had been spatially more extensive. Recent oxygen isotope-based paleoaltimetry study shows that SE margin of the Tibetan Plateau was at its present elevation of $\sim 3 \mathrm{~km}$ as early as late Eocene time (Hoke et al., 2014). Whereas, whether this high late Eocene elevation was entirely obtained through rapid uplift after the initial collision between India and Asia, or was partially inherited from precollisional topography of a Late Cretaceous 'proto-plateau' is unclear. The puzzle could only be resolved if pre-Cenozoic elevation history of SE Tibet is constrained. 


\section{Oxygen isotope-based paleoaltimetry}

Oxygen isotope-based paleoaltimetry (e.g., Currie et al., 2005; Graham et al., 2005; Hren et al., 2009; Kent-Corson et al., 2009; Mulch et al., 2010; Polissar et al., 2009; Quade et al., 2011; Quade et al., 2007; Rowley and Garzione, 2007; Saylor et al., 2009) is a widely used technique for evaluating surface elevation history that is independent from other surface uplift indicators (e.g., crustal deformation and rock cooling history). The method is based on the fractionation of oxygen isotopes from atmospheric water vapor to rainfall, in a process known as 'Rayleigh distillation' (Blisniuk and Stern, 2005; Craig and Gordon, 1965; Dansgaard, 1964; Poage and Chamberlain, 2001; Rowley and Garzione, 2007). In general, $\delta^{18} \mathrm{O}$ values of meteoric waters tend to decrease with increasing surface elevations at certain isotopic-elevation gradient (e.g., global average $=\sim-2.8 \%$ o/km) (Poage and Chamberlain, 2001; Rowley, 2007). Therefore, paleo-elevations can be estimated if $\delta^{18} \mathrm{O}$ signals of paleo-meteoric waters are preserved in geologic records (e.g., lacustrine carbonate, soil carbonate, fossil shells) and proper isotopic lapse rates can be assumed. Soil carbonates are one of the most widely used proxies for $\delta^{18} \mathrm{O}$ values of paleo-meteoric waters (e.g., Graham et al., 2005; Quade et al., 2007; Saylor et al., 2009; Mulch et al., 2010; Quade et al., 2011) and appear to provide the best record of paleoprecipitation as they grew from soil waters mostly sourced from rain waters fall directly on the paleo-ground (Rowley and Garzione, 2007). However, applicability of oxygen isotope-based paleoaltimetry is often complicated by: 1) uncertainty of oxygen isotopic fractionation factor between minerals (e.g., pedogenic carbonate) and the waters from which they grew as the fractionation is temperature-dependent (Kim and O'Neil, 1997); 2) enrichment of heavy oxygen isotopes in surface waters by evaporation (e.g., Quade et al., 2007); and 3) climatic influences (e.g., moisture source, atmospheric circulation patterns and seasonality of carbonate 
precipitation) on $\delta^{18} \mathrm{O}$ values of surface waters and therefore precipitated carbonate minerals (e.g., Garzione et al., 2000).

\section{Clumped isotope-based paleoaltimetry}

Carbonate clumped isotope thermometry is an innovative technique that is capable of measuring the formation temperature of carbonate minerals (e.g., Eiler, 2007; Ghosh et al., 2006). Different from conventional stable isotope techniques, clumped isotope thermometry measures the abundance of mass- 47 (which reflects the abundance of ${ }^{13} \mathrm{C}_{-}{ }^{18} \mathrm{O}$ bond) in $\mathrm{CO}_{2}$ produced by acid-digestion of carbonate minerals (e.g., Ghosh et al., 2006; Eiler, 2007). Since "clumping" of ${ }^{13} \mathrm{C}$ and ${ }^{18} \mathrm{O}$ ions in carbonate minerals is temperature-dependent, abundance of ${ }^{13} \mathrm{C}_{-}{ }^{18} \mathrm{O}$ bonds (reported as " $\Delta_{47}$ ") (Eiler and Schauble, 2004) can be correlated to formation temperature of carbonate minerals (e.g., Eiler and Schauble, 2004; Ghosh et al., 2006; Tripati et al., 2015). The $\Delta_{47}$-derived temperature $\left(\Delta_{47}-\mathrm{T}\right)$ of carbonate minerals (e.g., soil carbonate, lacustrine carbonate, fossil shell) can then be correlated to surface air temperatures (e.g., Hough et al., 2014; Hren and Sheldon, 2012; Quade et al., 2013; Tripati et al., 2010). For example, it has been suggested that $\Delta_{47}$-Ts recorded by soil carbonate usually reflect warm season surface air temperatures (e.g., Quade et al., 2013; Hough et al., 2014). After surface temperatures are constrained, paleo-elevation histories can be assessed by applying appropriate temperatureelevation lapse rates (e.g., global average $=\sim 5.5^{\circ} \mathrm{C} / \mathrm{km}$ ) (Meyer, 1992; Meyer, 2007), if other temperature-influencing factors (e.g., climate change or seasonality of carbonate growth) can be ruled out. Furthermore, constraint on carbonate forming temperature also makes estimation of $\delta^{18} \mathrm{O}$ values of meteoric water $\left(\delta^{18} \mathrm{O}_{\text {water }}\right)$ from which carbonate grew more accurate as fractionation of $\mathrm{O}^{18}$ between carbonate and water is temperature-dependant (Kim and O'Neil, 
1997). The combination of $\delta^{18} \mathrm{O}$ - and $\Delta_{47}$-based paleoaltimetry techniques provide two independent controls on paleo-elevation histories and have so far yielded some of the most robust paleo-elevation estimates (e.g., Carrapa et al., 2014; Fan et al., 2014; Garzione et al., 2014; Huntington et al., 2015; Leier et al., 2013; Snell et al., 2014).

\section{Purpose of the study}

Here, we present estimates of Late Cretaceous (Coniacian-Santonian) soil temperatures and $\delta^{18} \mathrm{O}_{\text {water }}$ values for SE Tibet from carbonate clumped isotope thermometry on paleosol carbonates collected from the Markam area (Fig. 1). Combined with soil temperature and $\delta^{18} \mathrm{O}_{\text {water }}$ data from the underlying Cenomanian-Turonian strata (Shang et al., in review), we first reconstruct the Cenomanian-Santonian ( 100 to $83 \mathrm{Ma})$ surface temperature history of SE Tibet. Then, the soil temperature records are compared with contemporaneous global climate inferred from marine temperature datasets (Bornemann et al., 2008; Forster et al., 2007; Huber et al., 2002; Voigt et al., 2004) in terms of magnitude and temporal evolution. Soil temperature variations that are inconsistent with global climate patterns are used to determine local paleoelevation changes for SE Tibet during Late Cretaceous time. The method can be potentially complicated by several factors: 1) terrestrial climate change may or may not response consistently with marine temperature change (e.g., Lunt et al., 2010); 2) changes of seasonality/timing of soil carbonate growth through time; and 3) uncertainty of temperatureelevation gradient during Late Cretaceous. To better constrain how global climate change affects soil temperatures during Late Cretaceous time, we used a general circulation model HadCM3L (Lunt et al., 2015) to simulate soil temperatures (at depth of 25-65 cm) for East Asia. High resolution $\left(0.5^{\circ} \times 0.5^{\circ}\right)$ paleogeographic reconstructions for each studied geologic stages 
(provided by Getech Plc; Fig. 2) used in the model assume constant paleo-elevation for SE Tibet through the studied Late Cretaceous interval (i.e., Cenomanian-Santonian), with the purpose of limiting the topographic effects on soil temperatures. Seasonality of soil carbonate growth is assessed using simulated atmospheric circulation patterns and monthly precipitation data as the timing of soil carbonate growth is controlled by amount and seasonality of precipitation (e.g., Peters et al., 2013; Rohrmann et al., 2014). In addition, we report strontium isotope data and structural observations from the Marakam paleosol record, with the aim of characterizing continental weathering and syn-tectonic depositions. Together, the combination of $\Delta_{47}-\mathrm{T}$, $\delta^{18} \mathrm{O}_{\text {water, }}$, climate simulation, strontium isotope, and structure observation are used to determine if the observed Late Cretaceous soil temperature trend in SE Tibet was caused by surface uplift, global climate change, or the combination of both.

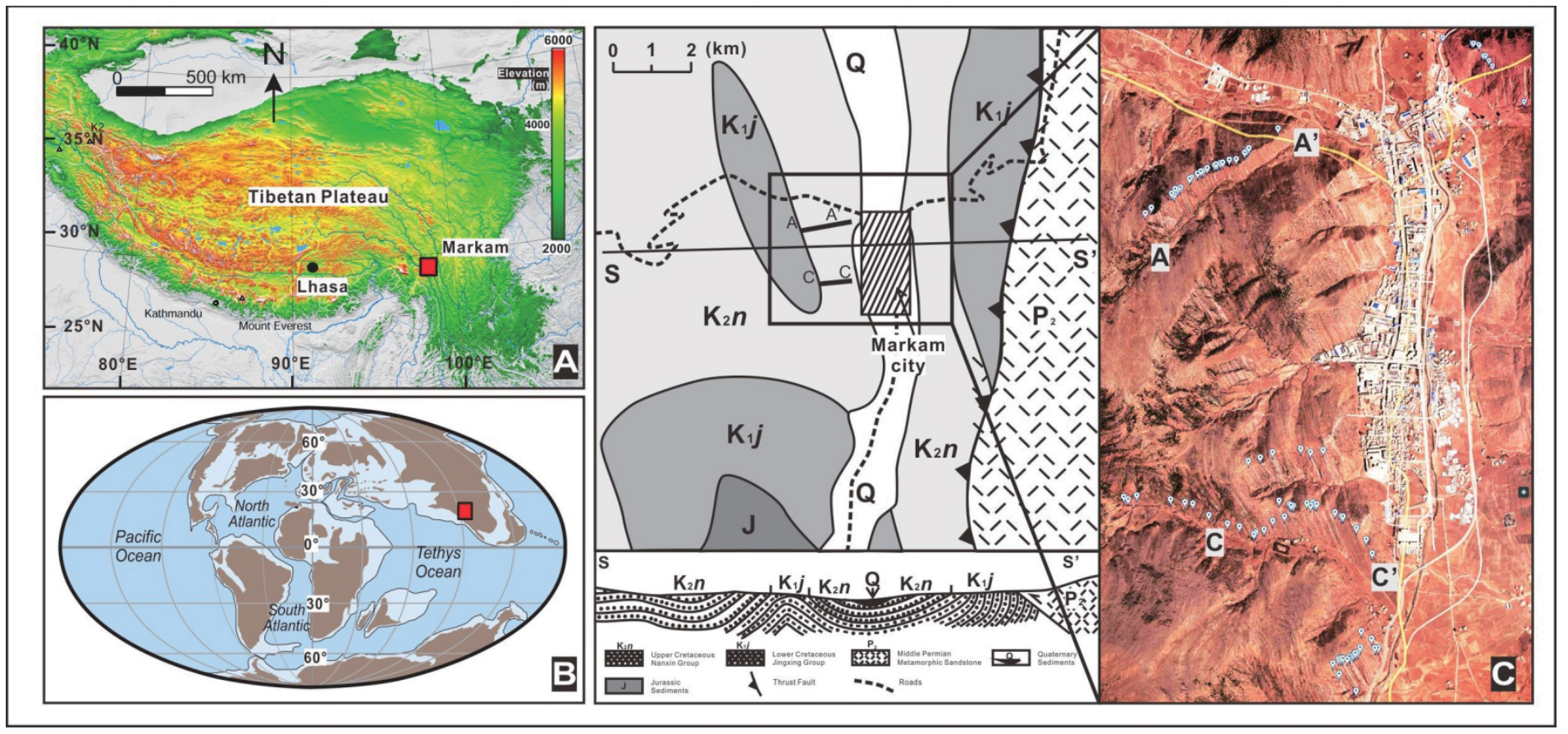

Figure 1. (A) Topographic map of the Tibetan Plateau (NGDR, 1999) showing location of the study area (red square). (B) Global paleogeographic reconstruction of Late Cretaceous. Figure 
adapted from Jarvis et al. (2011) based on the paleogeographic reconstruction of Blakey (2008). Red square marks the estimated location of SE Tibet. (C) Local geologic (Pan et al., 2004) and satellite (Digital Global, 215) maps of the Markam area, showing local lithology and structural features as well as locations of the two studied sections (after Shang et al., in review).

\section{Geologic Background}

\section{Paleogeography and stratigraphy}

Our study site is located in the Markam County of SE Tibet where Cretaceous red beds are presents (Fig. 1). Previous paleomagnetic work in the Markam area suggests the region was located at between $\sim 20-40{ }^{\circ} \mathrm{N}$ during Late Cretaceous time (Huang et al., 1992). Recent highresolution paleomagnetic data from the southern Lhasa terrane reveals that the region maintained relatively stable at $\sim 20-25^{\circ} \mathrm{N}$ paleo-latitude during Late Cretaceous before drifted northward to its current latitude at $\sim 30^{\circ} \mathrm{N}$ since Late Eocene (Lippert et al., 2014). Here, we suggest that paleo-latitude of our study site in SE Tibet was similar to that of suggested by Lippert et al. (2014), as indicated by relatively short distance $(\sim 700 \mathrm{~km})$ between our study site and the place in the southern Lhasa terrane where paleomagnetic samples were collected (Lippert et al., 2014), as well as almost identical current day latitudes between the two places (Markam: 29 $31^{\prime} \mathrm{N}$; southern Lhasa terrane: $\left.\sim 30^{\circ} \mathrm{N}\right)$.

Cretaceous strata in the Markam area of SE Tibet cover an area of $\sim 2,000 \mathrm{~km}^{2}$ and contain 1,200 m thick terrestrial deposits composed of clast-supported conglomerate, crossstratified pebbly red sandstone, and thick-bedded carbonate nodule-bearing paleosol layers

underlain by Triassic-Jurassic marine-lacustrine deposits (Du et al., 1997; Pan et al., 2004). The Cretaceous sequence is further divided into two units: the Early Cretaceous (late Aptian-Albian) 
Jingxing Formation and the Late Cretaceous (Cenomanian-Santonian) Nanxing Formation (GSX, 2007; Huang et al., 1992; Pan et al., 2004). The Late Cretaceous Nanxing Formation consists of $\sim 600 \mathrm{~m}$ of red to purplish lithic sandstone, interbedded with layers of conglomerate, pebbly sandstone, mudstone, and carbonate nodule-bearing paleosol horizons (Du et al., 1997; GSX, 2007). Stage boundaries and ages within the Nanxing Formation are determined based on magnetostratigraphy (Huang et al., 1992; Otofuji et al., 1990), terrestrial macrofossil record (GSX, 2007), and palynological data from Shang et al. (in review) (Fig. A.1.). Depositional ages of the lower Nanxing Formation is constrained at between Cenomanian and Turonian ( 100-89 $\mathrm{Ma}$ ), and that of the upper Nanxing Formation is constrained at between Coniacian and Santonian ( 89-93 Ma) (Fig. A.1.). 


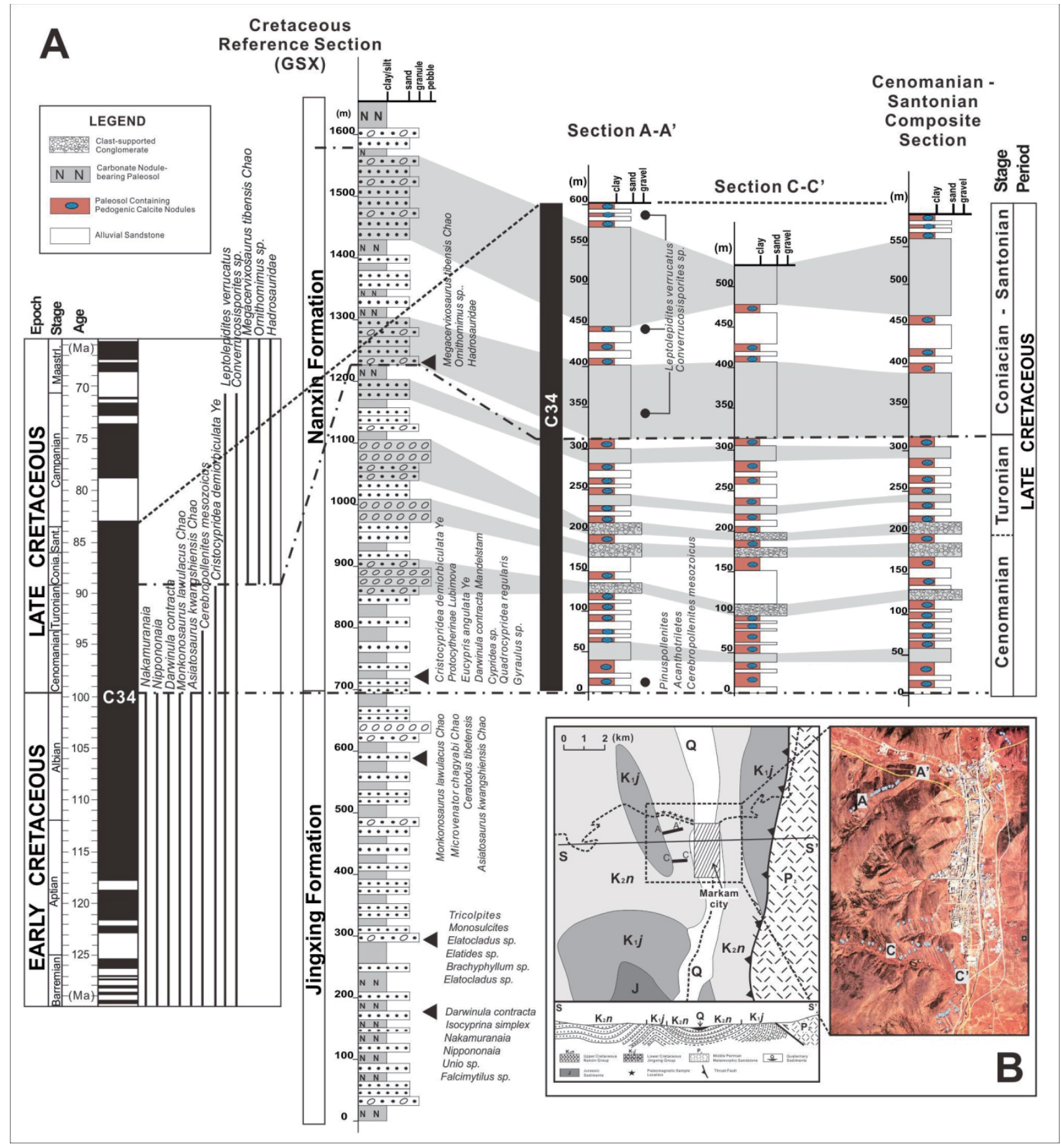

Figure A.1. (A) Stratigraphic column and age control of the Late Cretaceous sequence (Shang et al., in review). (B) Local satellite map of studied sections exposed near the city of Markham.

\section{Existing Late Cretaceous (Cenomanian-Turonian) soil temperature record}

Previous study (Shang et al., in review) has reported soil temperatures from the lower 
Nanxing Formation (i.e., Cenomanian-Turonian interval) in the Markam area based on clumped isotope thermometry on soil carbonate. The study reveals a terrestrial warming trend through the Cenomanian-Turonian interval, with average soil temperatures increased from $\sim 35^{\circ} \mathrm{C}$ in the Cenomanian to $\sim 44{ }^{\circ} \mathrm{C}$ in the Turonian (Shang et al., in review). The observed soil temperature trend closely mirrors coeval global climate inferred from marine dataset. Subtropical sea surface temperatures (SSTs) indicated by geochemistry of brachiopod shell show a long-term warming trend through the Cenomanian-Turonian interval (Voigt et al., 2004). Similarly, tropical SSTs derived from $\mathrm{TEX}_{86}$ proxy show that SSTs raised from $\sim 31^{\circ} \mathrm{C}$ in the Cenomanian to $\sim 35{ }^{\circ} \mathrm{C}$ in the Turonian (Bornemann et al., 2008; Forster et al., 2007). Together, continental and marine records both reveal an episode of global warming during the Cenomanian-Turonian time (e.g., Clarke and Jenkyns, 1999; Voigt et al., 2004).

\section{Analytical method}

\section{Sampling}

We sampled 8 carbonate nodule-bearing paleosol horizons in the upper Nanxing Formation (Coniacian-Santonian in age) from two measured sections (i.e., sections: A-A', C-C') (Fig. 1C). Five samples were taken from section A-A' and the rest three samples were collected from section C-C'. The sampled paleosol layers are all classified as Calcisol according to the paleosol classification scheme of Mack et al. (1993). Carbonate nodules were collected at depth of $\sim 50 \mathrm{~cm}$ below top of the preserved paleosol surface to constrain variation of soil temperature with depth (e.g., Quade et al., 2013). Four additional paleosol carbonate samples collected in previous study from the lower Nanxing Formation (Cenomanian-Turonian in age) (Shang et al., in review) are also included in this study for strontium isotope $\left({ }^{87} \mathrm{Sr} /{ }^{86} \mathrm{Sr}\right)$ analysis. 
Carbonate nodules were first cut in halves, polished and examined under transmitted light using microscope. For $\Delta_{47}$ analysis, only the areas with homogeneous micritic textures were carefully sampled using a low-speed dremel drill with periodic cooling of the drill pit to avoid potential resetting of the samples. Carbonate powders were drilled from multiple places within a nodule and mixed together; therefore, the resultant soil temperature most likely represents averaged climate conditions during the course of soil nodule formation. For X-ray diffraction (XRD), $\mathrm{Mg} / \mathrm{Ca}, \mathrm{Sr} / \mathrm{Ca}$ ratios and strontium isotope $\left({ }^{87} \mathrm{Sr} /{ }^{86} \mathrm{Sr}\right)$ analyses, since the required sample sizes are larger ( $>2$ gram), nodule samples were first broken into fine pieces $(<0.5 \mathrm{~cm}$ in diameter) and examined under microscope to avoid sampling the pieces that contain visible carbonate veins and spars. Selected portions were then grounded into powders using a ceramic mortar and pestle.

\section{Petrographic, mineralogical and isotopic screening for diagenesis}

Carbonate diagenesis is assessed using a combination of petrology, mineralogy, and isotopic approaches. Polished petrographic thin sections were produced for all carbonate nodule samples $(\mathrm{n}=8)$ and examined under transmitted and cross-polarized lights to characterize carbonate textures (i.e., micrite versus sparry cement). X-ray diffraction (XRD) analysis was performed on all 8 samples using a PANalytical X'Pert Pro XRD diffractometer equipped with $\mathrm{Cu} \mathrm{K} \alpha$ radiation at $40 \mathrm{keV}$ and $40 \mathrm{~mA}$. Samples were scanned from $10^{\circ}$ to $100^{\circ}$ at $2 \theta$ with a step interval of $0.05^{\circ}$. Interpretation of mineralogy was aided by Highscore Plus software equipped with the Powder Diffraction File 3 database. $\mathrm{Sr} / \mathrm{Ca}$ and $\mathrm{Mg} / \mathrm{Ca}$ ratios of the 8 carbonate samples were measured at Actlabs, Canada. Carbonate phases were first dissolved in $0.5 \mathrm{M}$ acetic acid follow the method of Ray et al. (1957), and then analyzed by inductively coupled plasma mass 
spectrometry (ICP-MS) for $\mathrm{Ca}, \mathrm{Mg}$ and $\mathrm{Sr}$ concentrations. In addition, isotopic (i.e., $\delta^{18} \mathrm{O}$ and $\left.\delta^{13} \mathrm{C}\right)$ screening was performed on carbonate samples $(n=6)$ that contain both micritic and sparry textures, with the purpose of characterizing carbonate diagenetic history (e.g., Garzione et al., 2004). Micrite and co-existing sparry cement were micro-sampled ( $\mathrm{n}=1$ for cement; $\mathrm{n}=2$ for micrite; average sample size $=0.3 \mathrm{mg}$ ) using a hand drill. Isotopic analysis was performed at West Virginia University Stable Isotope Lab. Samples were measured using a GasBench device coupled to a Delta Advantage isotope ratio mass spectrometer. Results of $\delta^{13} \mathrm{C}$ and $\delta^{18} \mathrm{O}$ were standardized using NBS18 and NBS19 carbonate standards. Analytical precision is better than \pm 0.1 for $\delta^{13} \mathrm{C}$ and $\delta^{18} \mathrm{O}(1 \mathrm{~s})$, based on repeated analysis of internal standards.

\section{Strontium isotope analysis}

Strontium isotope $\left({ }^{87} \mathrm{Sr} /{ }^{86} \mathrm{Sr}\right)$ analysis of paleosol carbonate samples $(\mathrm{n}=8)$ was conducted at the Center for Applied Isotope Studies, University of Georgia. Carbonate fraction was first extracted with $0.5 \mathrm{M}$ acetic acid. ${ }^{87} \mathrm{Sr} /{ }^{86} \mathrm{Sr}$ measurement was conducted by dynamic multicollection on the Sector 54. Extracted $\mathrm{Sr}$ is loaded onto Re filaments with $\mathrm{H}_{3} \mathrm{PO}_{4}$ and $\mathrm{TaCl}_{5}$ activator, and produces a stable beam for several hours. The external reproducibility of ${ }^{87} \mathrm{Sr} /{ }^{86} \mathrm{Sr}$ analyses is better than $25 \mathrm{ppm}(2 \sigma)$ based on analyses of past 10 years, with ${ }^{87} \mathrm{Sr} /{ }^{86} \mathrm{Sr}$ of NBS 987 measured over that time period averages $0.710246 \pm 0.000011(2 \sigma)$.

\section{Clumped isotope analysis}

Carbonate clumped isotope was measured at University of California, Los Angeles (UCLA) stable isotope lab, using a specially modified Thermo Fisher 253 gas source mass 
spectrometer with mass 44-49 ion collectors ("Chewbacca"). Samples and carbonate standards were processed using an automated system for acid digestion and purification (after Passey et al., 2010) before transferred to the inlet of the mass spectrometer. For each measurement, $10-12 \mathrm{mg}$ of sample powders were digested at $90{ }^{\circ} \mathrm{C}$ in phosphoric acid, the resultant $\mathrm{CO}_{2}$ being cryogenically purified before analysis on the mass spectrometer. Absolute reference frame (ARF) was established by analyzing equilibrium $\mathrm{CO}_{2}$ samples prepared at $1000{ }^{\circ} \mathrm{C}$ and $25^{\circ} \mathrm{C}$. The standard gas are purified and analyzed using the same protocol as gases generated from carbonate samples. For carbonates, the $\Delta_{47}$ values are normalized to $25^{\circ} \mathrm{C}$ using a $0.092 \%$ value from Passey et al. (2010) as recalculated in Henkes et al., 2013. Clumped-isotope data of pedogenic carbonate are reported relative to the ARF of Dennis et al. (2011). $\Delta_{47}$-temperatures are calculated using the inorganic calibration of Tripati et al. (2015), generated on the same instrument. Uncertainties in reported $\Delta_{47}$ values and calculated temperatures include the propagated uncertainty in equilibrated gas determination and in sample measurement. Three internal carbonate standards (i.e., Carrerra Marble, Carmel Chalk and Veinstorm Limestone) were analyzed multiple times during the course of the clumped isotope analysis, which yield mean $\Delta_{47}$ values of $0.390 \pm 0.012 \%$ o $(n=11), 0.697 \pm 0.014 \%$ o $(n=8)$, and $0.725 \pm 0.011 \%$ o $(n$ =12), respectively (Table A.1.). The standard errors (SE) for $\Delta_{47}$ values reported in Table 2 are calculated as $\mathrm{SE}=\mathrm{SD} / \mathrm{SQRT}(\mathrm{N})$, where $\mathrm{SD}$ is the observed standard deviation for repeated analyses of samples, and $\mathrm{N}$ is the number of repeated analyses. If the observed $\mathrm{SE}$ is smaller than the long-term lab precision $(0.009 \%$ ), $\mathrm{SE}$ is calculated using $\mathrm{SD}=0.009 \%$ (Tripati et al., 2015). Error in $\Delta_{47}-\mathrm{T}$ is calculated by propagating the $\mathrm{SE}$ for $\Delta_{47}$ through the Tripati et al. (2015) temperature calibration equation.

The $\delta^{13} \mathrm{C}$ and $\delta^{18} \mathrm{O}$ ratios were measured during the course of clumped isotope analysis 
and reported relative to VPDB standard, with analytical precisions all $>0.1 \%$. The $\delta^{18} \mathrm{O}$ values of soil water $\left(\delta^{18} \mathrm{O}_{\text {water }}\right)$ were then calculated using the $\Delta_{47}-\mathrm{T}$ and temperature-dependant oxygen fractionation equation between calcite and water (Kim and O'Neil, 1997). Errors of the calculated $\delta^{18} \mathrm{O}_{\text {water }}$ values reflect uncertainties of $\Delta_{47}-\mathrm{T}$ measurement.

\section{Cretaceous climate simulation}

To investigate the impact of global climate change on soil temperatures in SE Tibet, we used the General Circulation Model (GCM) HadCM3L $\left(3.75^{\circ} \times 2.5^{\circ}\right.$ atmosphere and ocean resolution) (Lunt et al., 2015), a fully coupled Atmosphere-Ocean General Circulation model modified from the HadCM3 model (Gordon et al., 2000), to generate soil temperature at depth of 25-65 cm, sea surface temperature (SST), precipitation and atmospheric circulation pattern data for East Asia (5-60 ${ }^{\circ} \mathrm{N}$ paleo-latitude, 50-160 ${ }^{\circ} \mathrm{E}$ paleo-longitude) during summer months (i.e., June, July, August and September). It has been suggested that soil carbonates typically form in warm summer months (Hough et al., 2014; Passey et al., 2010; Quade et al., 2013) and therefore record warm season climatic conditions. Four time-slice simulations were constructed utilizing high-resolution $\left(0.5^{\circ} \times 0.5^{\circ}\right)$ paleogeographic boundary conditions created by Getch Plc using the method of Markwick (2007) (Fig. 2), including the Cenomanian (100.5-93.9 Ma), Turonian (93.9-89.8 Ma), Coniacian (89.8-86.3 Ma) and Santonian (86.3-83.6 Ma) geological stages (Gradstein et al., 2004). Note that each time-slice does not represent specific date in geologic record due to age uncertainty of proxy data used in the simulation. Instead, the reconstructions reflect time-averaged mid-point condition for each geologic stage (Lunt et al., 2015).

Unlike marine temperatures that mostly reflect global climate conditions, land surface temperatures can be affected by both global climate and local topography (e.g., the modern day 
Tibetan Plateau). Our model simulations limit the effects of topography on soil temperatures by prescribing a relatively constant elevation values $(1000 \pm 200 \mathrm{~m})$ throughout the modeled time interval (Fig. 2). Therefore, any variation of soil temperature between simulated geologic stages is likely due to changes of global climate rather than local topography.

The climate model provides the most temporally and spatially comprehensive Cretaceous climate simulations that are currently available (Lunt et al., 2015). A more detailed model description including parameters used during simulation (e.g., solar luminosity, paleogeography, $p \mathrm{CO}_{2}$ ) can be found in Lunt et al. (2015).

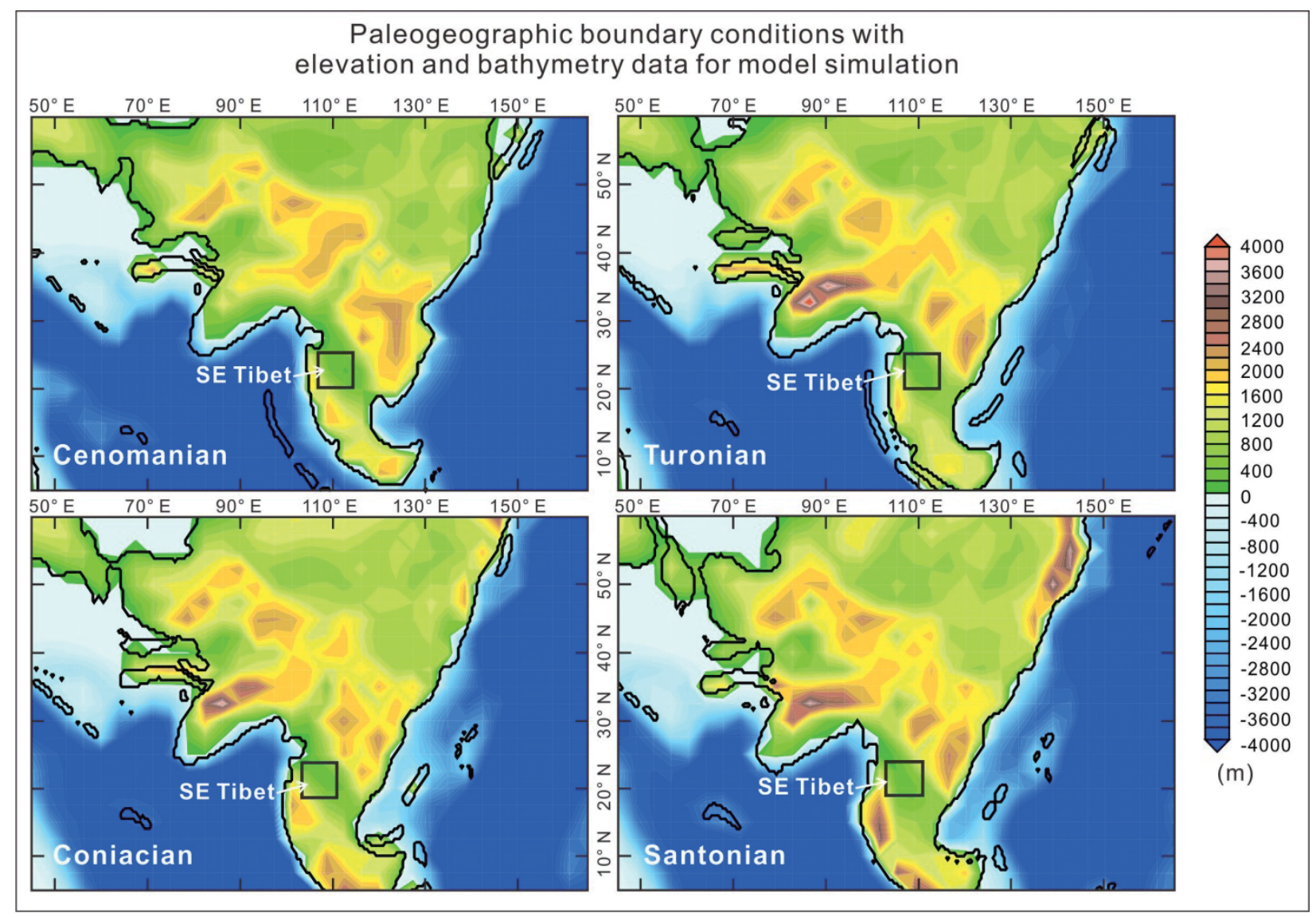

Figure 2. Paleogeographic boundary conditions for the Cenomanian, Turonian, Coniacian and Santonian time-slices used in climate simulation, showing elevation and bathymetry (Getech Plc). Note that the area corresponds to current day SE Tibet (marked by black square) is assumed 
to have relatively constant paleoelevation $(1000 \pm 200 \mathrm{~m})$ during the Cenomanian-Santonian time.

\section{Results}

\section{Petrographic, mineralogical and isotopic screening for diagenesis}

Thin-section petrographic studies show that the pedogenic carbonate nodules are dominated by red-brown micrite texture with occasional crack-filling sparry cement (Fig. 3). The spars have distinct crystal boundaries from the surrounding micritic groundmass (Fig. 3D). 'Floating' angular quartz grains are common (Fig. 3) and no detrital carbonate grains are found in thin sections. Results of XRD mineralogy, $\mathrm{Sr} / \mathrm{Ca}$ and $\mathrm{Mg} / \mathrm{Ca}$ elemental ratios are presented in Table 1. Computer-aided mineral identification suggests that calcite is the major component and only carbonate mineral present. Secondary components include quartz and minor clay minerals. Elemental analysis of carbonates shows low $\mathrm{Mg} / \mathrm{Ca}$ and $\mathrm{Sr} / \mathrm{Ca}$ ratios $(<0.01)$ (Table 1). 

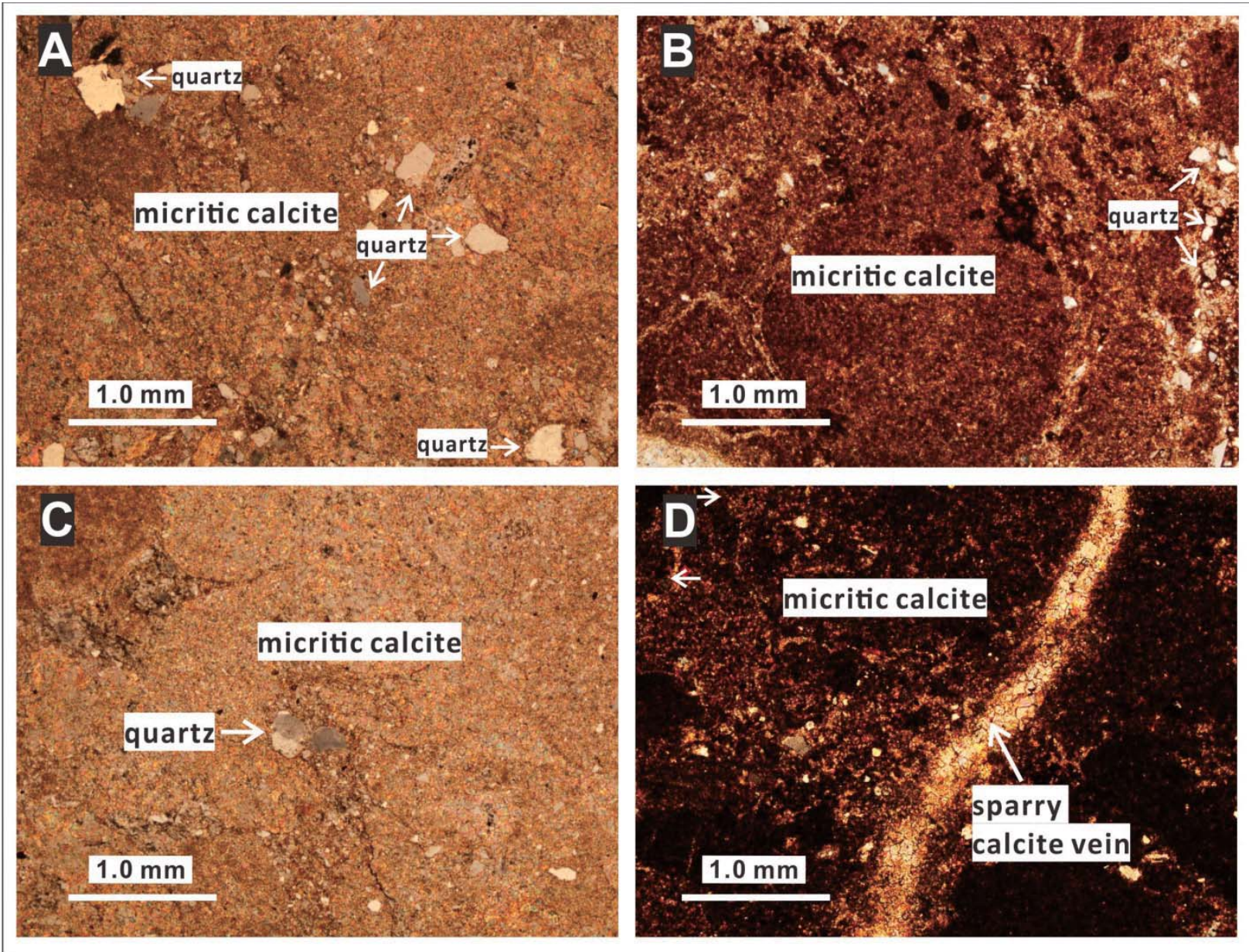

Figure 3. Thin-section photos of studied carbonate nodules. (A-C) Thin-section photos of paleosol carbonate nodules taken under polarized lights showing dominant micritic texture. Detrital quartz grains are 'floating' in micritic groundmass. (D) Photomicrograph taken under polarized lights showing crack-filling sparry cement. Only the areas with homogeneous micritic texture were sampled for clumped isotopic analyses. 
Table 1. Results of XRD, $\mathrm{Mg} / \mathrm{Ca}$ and $\mathrm{Sr} / \mathrm{Ca}$ ratios, and strontium isotope analyses

\begin{tabular}{|c|c|c|c|c|c|c|c|c|}
\hline \multirow{2}{*}{$\begin{array}{c}\text { Sample } \\
\text { ID }\end{array}$} & \multirow{2}{*}{$\begin{array}{l}\text { Stratigraphic } \\
\text { Position } \\
\text { (m) }\end{array}$} & \multicolumn{4}{|c|}{ XRD results } & \multicolumn{2}{|c|}{ Elemental results } & \multirow{2}{*}{$\frac{\mathrm{Sr} \text { isotope }}{{ }^{87} \mathrm{Sr} /{ }^{86} \mathrm{Sr}}$} \\
\hline & & $\begin{array}{c}\text { Number of } \\
\text { counts }\end{array}$ & $\begin{array}{c}100 \% \\
2^{\circ} \theta\end{array}$ & $\begin{array}{c}100 \% \\
\text { d-spacing }(\AA)\end{array}$ & Main component & $\mathrm{Mg} / \mathrm{Ca}$ & $\mathrm{Sr} / \mathrm{Ca}$ & \\
\hline \multicolumn{9}{|c|}{ Section A-A' } \\
\hline MK6331 & 582 & 77387 & 29.256 & 3.05275 & Calcite, Quartz & 0.0046 & 0.0006 & N/A \\
\hline MK6330 & 573 & 73436 & 29.320 & 3.04619 & Calcite, Quartz & 0.0050 & 0.0005 & 0.7112 \\
\hline MK6329 & 560 & 71706 & 29.437 & 3.03666 & Calcite, Quartz & 0.0062 & 0.0007 & N/A \\
\hline MK6328 & 418 & 10113 & 29.485 & 3.02950 & Calcite, Quartz & 0.0048 & 0.0006 & N/A \\
\hline MK6327 & 390 & 75915 & 29.333 & 3.04488 & Calcite, Quartz & 0.0052 & 0.0008 & 0.7107 \\
\hline MK6325* & 281 & & & & & & & 0.7106 \\
\hline MK6319* & 215 & & & & & & & 0.7104 \\
\hline MK6317* & 192 & & & & & & & 0.7106 \\
\hline MK6315* & 107 & & & & & & & 0.7104 \\
\hline \multicolumn{9}{|c|}{ Section C-C' } \\
\hline MK6234 & 455 & 37780 & 29.203 & 3.05812 & Calcite, Quartz & 0.0062 & 0.0007 & 0.7110 \\
\hline MK6233 & 410 & 7687 & 29.483 & 3.02969 & Calcite, Quartz & 0.0238 & 0.0008 & 0.7106 \\
\hline MK6232 & 395 & 14724 & 29.487 & 3.02933 & Calcite, Quartz & 0.0154 & 0.0009 & N/A \\
\hline
\end{tabular}

The $\delta^{18} \mathrm{O}$ and $\delta^{13} \mathrm{C}$ values of micrite and co-existing sparry cement show that the two types of carbonate phases have very similar isotopic values (Table 2). Variation of $\delta^{18} \mathrm{O}$ ratios between micrite and co-existing spars averages $0.21 \%$ and ranges from $0.04 \%$ o to $0.41 \%$, while the same variation for $\delta^{13} \mathrm{C}$ ratios averages $0.14 \%$ and ranges from $0.01 \%$ o to $0.32 \%$ (Table 2). In comparison, the $\delta^{18} \mathrm{O}$ and $\delta^{13} \mathrm{C}$ values of both micrite and spars can vary as much as $\sim 1.2 \%$ (for $\delta^{18} \mathrm{O}$ ) and $\sim 0.6 \%$ (for $\delta^{13} \mathrm{C}$ ) among different paleosol horizons (Table 2). 
Table 2. Isotopic values of micro-sampled micrite and co-existing sparry cement

\begin{tabular}{|c|c|c|c|c|c|c|c|c|c|c|c|c|}
\hline $\begin{array}{c}\text { Nodule } \\
\text { Sample ID }\end{array}$ & \multicolumn{2}{|c|}{ Nodule 1} & \multicolumn{2}{|c|}{ Nodule 2} & \multicolumn{2}{|c|}{ Nodule 3} & \multicolumn{2}{|c|}{ Nodule 4} & \multicolumn{2}{|c|}{ Nodule 5} & \multicolumn{2}{|c|}{ Nodule 6} \\
\hline $\begin{array}{c}\text { Sampling } \\
\text { Height }\end{array}$ & \multicolumn{2}{|c|}{$390 \mathrm{~m}$} & \multicolumn{2}{|c|}{$395 \mathrm{~m}$} & \multicolumn{2}{|c|}{$410 \mathrm{~m}$} & \multicolumn{2}{|c|}{$455 \mathrm{~m}$} & \multicolumn{2}{|c|}{$573 \mathrm{~m}$} & \multicolumn{2}{|c|}{$582 \mathrm{~m}$} \\
\hline $\begin{array}{c}\delta^{13} \mathrm{C}, \delta^{18} \mathrm{O} \\
(\% o, \text { VPDB }) \\
\text { micrite } 1\end{array}$ & -9.03 & -12.28 & -9.14 & -12.14 & -9.25 & -12.10 & -8.73 & -11.12 & -8.99 & -12.31 & -8.50 & -11.97 \\
\hline $\begin{array}{c}\delta^{13} \mathrm{C}, \delta^{18} \mathrm{O} \\
(\% o, \text { VPDB }) \\
\text { micrite } 2\end{array}$ & -8.95 & -11.97 & -9.02 & -11.76 & -9.41 & -11.86 & -8.89 & -11.56 & -8.73 & -12.03 & -8.54 & -11.54 \\
\hline $\begin{array}{c}\delta^{13} \mathrm{C}, \delta^{18} \mathrm{O} \\
(\% o, \text { VPDB }) \\
\text { spar }\end{array}$ & -9.0 & -12.2 & -9.34 & -11.8 & -9.54 & -12.16 & -8.71 & -11.19 & -8.8 & -11.9 & -8.41 & -11.70 \\
\hline
\end{tabular}

\section{Strontium isotope values}

Strontium isotope $\left({ }^{87} \mathrm{Sr} /{ }^{86} \mathrm{Sr}\right)$ ratios of paleosol carbonates from the Nanxing Formation range from 0.7104 to 0.7112 (Table 1). The ${ }^{87} \mathrm{Sr} /{ }^{86} \mathrm{Sr}$ values are all greater than 0.708 (i.e., ${ }^{87} \mathrm{Sr} /{ }^{86} \mathrm{Sr}$ ratio of Cretaceous sea water) (Gradstein et al., 2004), indicating a continental origin of soil carbonates free from marine influence. The ${ }^{87} \mathrm{Sr} /{ }^{86} \mathrm{Sr}$ values display an increasing upward trend within the Nanxing Formation, with ${ }^{87} \mathrm{Sr} /{ }^{86} \mathrm{Sr}$ ratios increase from $\sim 0.7106$ to $\sim 0.7112$ (Fig. 4).

\section{Clumped isotope values}

Isotopic results of paleosol carbonates from the upper Nanxing Formation, including $\delta^{18} \mathrm{O}_{\text {carbonate }}, \delta^{13} \mathrm{C}_{\text {carbonate }}, \Delta_{47}$, and calculated $\Delta_{47}-\mathrm{T}$ and $\delta^{18} \mathrm{O}_{\text {water }}$ values are listed in Tables 3. Raw data of clumped isotope analysis, including standards measured over the period of sample analysis are listed in Supplementary Table 1 . The carbonate samples have $\Delta_{47}$ values range from $0.622 \%$ to $0.669 \%$ (average $=0.638 \%$; $n=10$ ), which correspond to carbonate precipitation 


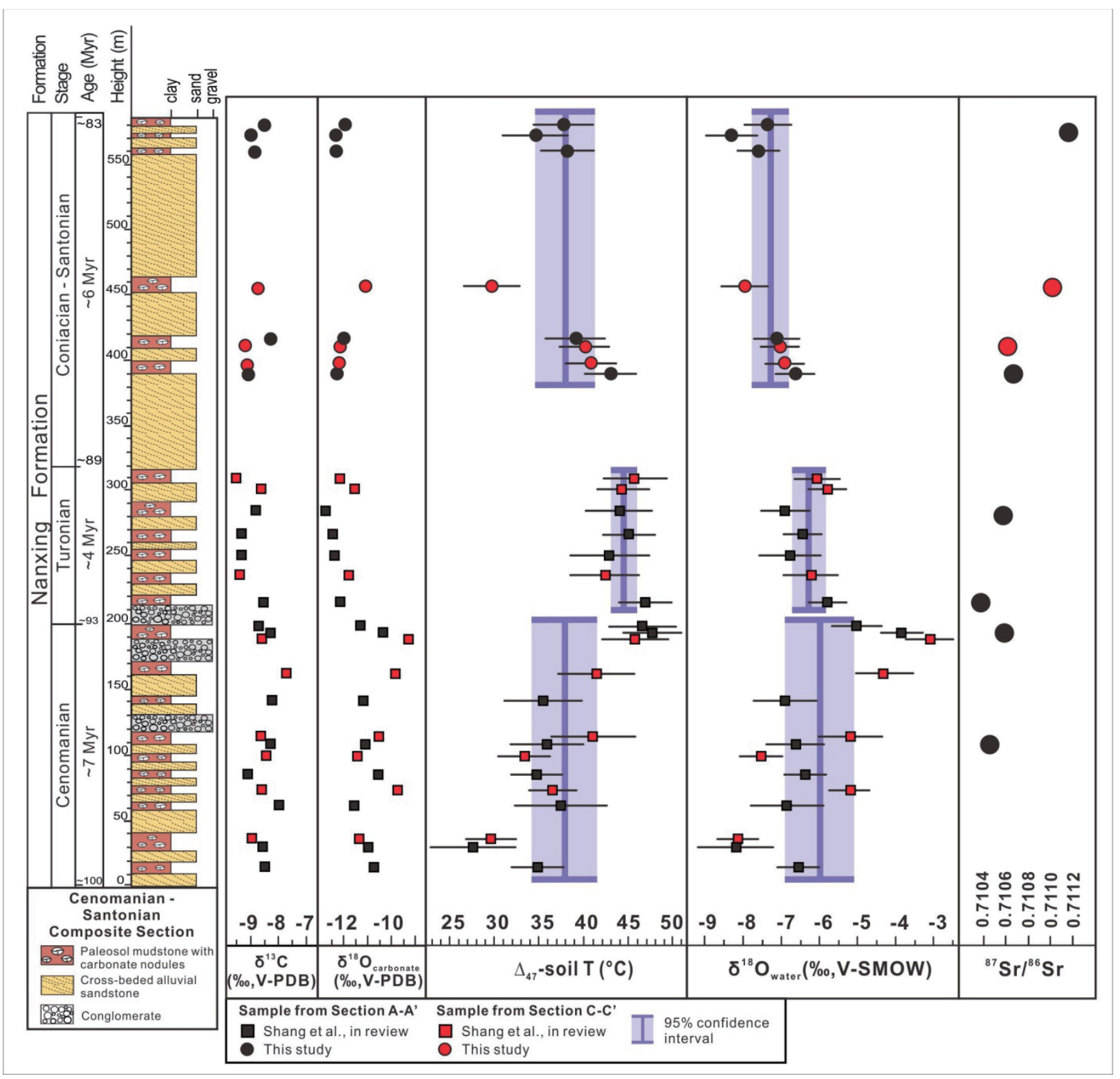

Figure 4. $\delta^{13} \mathrm{C}_{\text {carbonate }}, \delta^{18} \mathrm{O}_{\text {carbonate, }} \Delta_{47}$-temperature, $\delta^{18} \mathrm{O}_{\text {water }}$ and ${ }^{87} \mathrm{Sr} /{ }^{87} \mathrm{Sr}$ values plotted with stratigraphic depth. Filled circles represent samples from the upper Nanxing Formation (Coniacian-Santonain in age) analyzed in this study. Filled squares represent data from the lower Nanxing Formation (Cenomanian-Turonian in age) compiled from Shang et al., in review. Strontium isotope data are all obtained in this study. Purple shading represents $95 \%$ confidence interval (CI) of stage-averaged $\Delta_{47}-\mathrm{T}$ and $\delta^{18} \mathrm{O}_{\text {water }}$ means. 


\section{Cretaceous climate simulation}

The climate model simulations show that summer (i.e., June, July, August, and September) soil temperatures in SE Tibet are remarkably high and stable during the Cenomanian-Santonian time (Fig. 5). Estimated soil temperatures average $45 \pm 1.5{ }^{\circ} \mathrm{C}(95 \% \mathrm{CI})$ for Cenomanian; $44 \pm 2.6{ }^{\circ} \mathrm{C}(95 \% \mathrm{CI})$ for Turonian; $45 \pm 1.5{ }^{\circ} \mathrm{C}(95 \% \mathrm{CI})$ for Coniacian; and $45 \pm 1.3{ }^{\circ} \mathrm{C}(95 \% \mathrm{CI})$ for Santonian (Fig. 5). The modeled soil temperatures agree with high $\Delta_{47^{-}}$ soil Ts $\sim 40-45^{\circ} \mathrm{C}$ in SE Tibet during late Cenomanian-Turonian time (Shang et al., in review). In addition, the modeled surface sea temperatures (SSTs) show that tropical $\left(\sim 5-15^{\circ} \mathrm{N}\right) \mathrm{SST}$ in East Asia are relatively stable at $\sim 36^{\circ} \mathrm{C}$ throughout the simulated geologic stages (Fig. 6). The values are similar to SSTs in equatorial Atlantic indicated by TEX 86 proxy (Bornemann et al., 2008; Forster et al., 2007). The simulated summer wind patterns show that atmospheric circulations patterns were relatively unchanged throughout the Cenomanian-Santonian intervals, with winds predominantly blow from northwest to southeast (Fig. 7). The modeled summer precipitation data show that SE Tibet was characterized by arid-semiarid climate conditions with daily precipitation less than $1 \mathrm{~mm}$ /day during the simulated geologic interval (Fig. 7). 


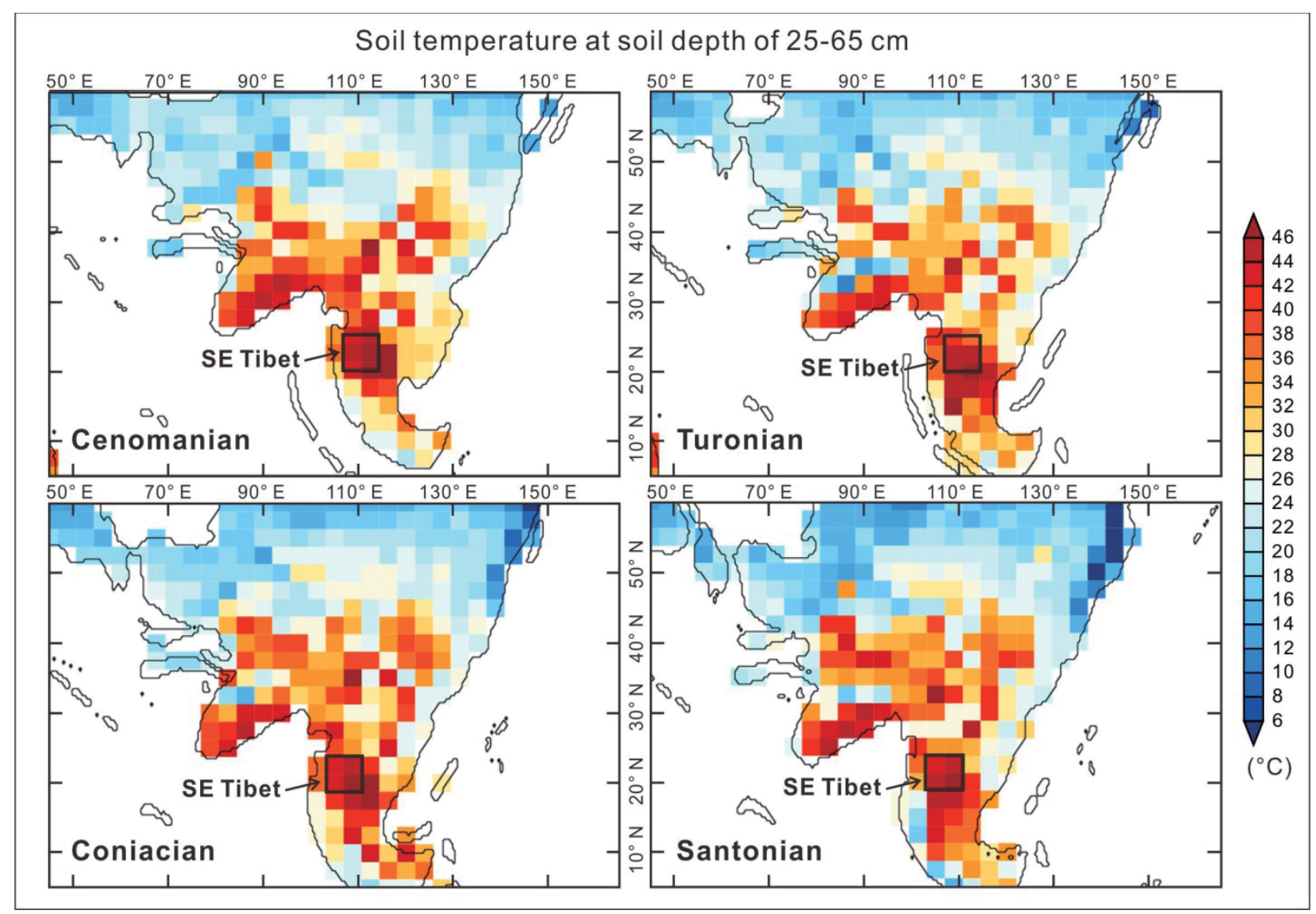

Figure 5. Model-derived summer (i.e., June, July, August, and September) soil temperature estimates. Simulations represent time-averaged conditions for four geologic time-slices: Cenomanian, Turonian, Coniacian, and Santonian. Soil temperatures are modeled for 25-65 cm depth. 


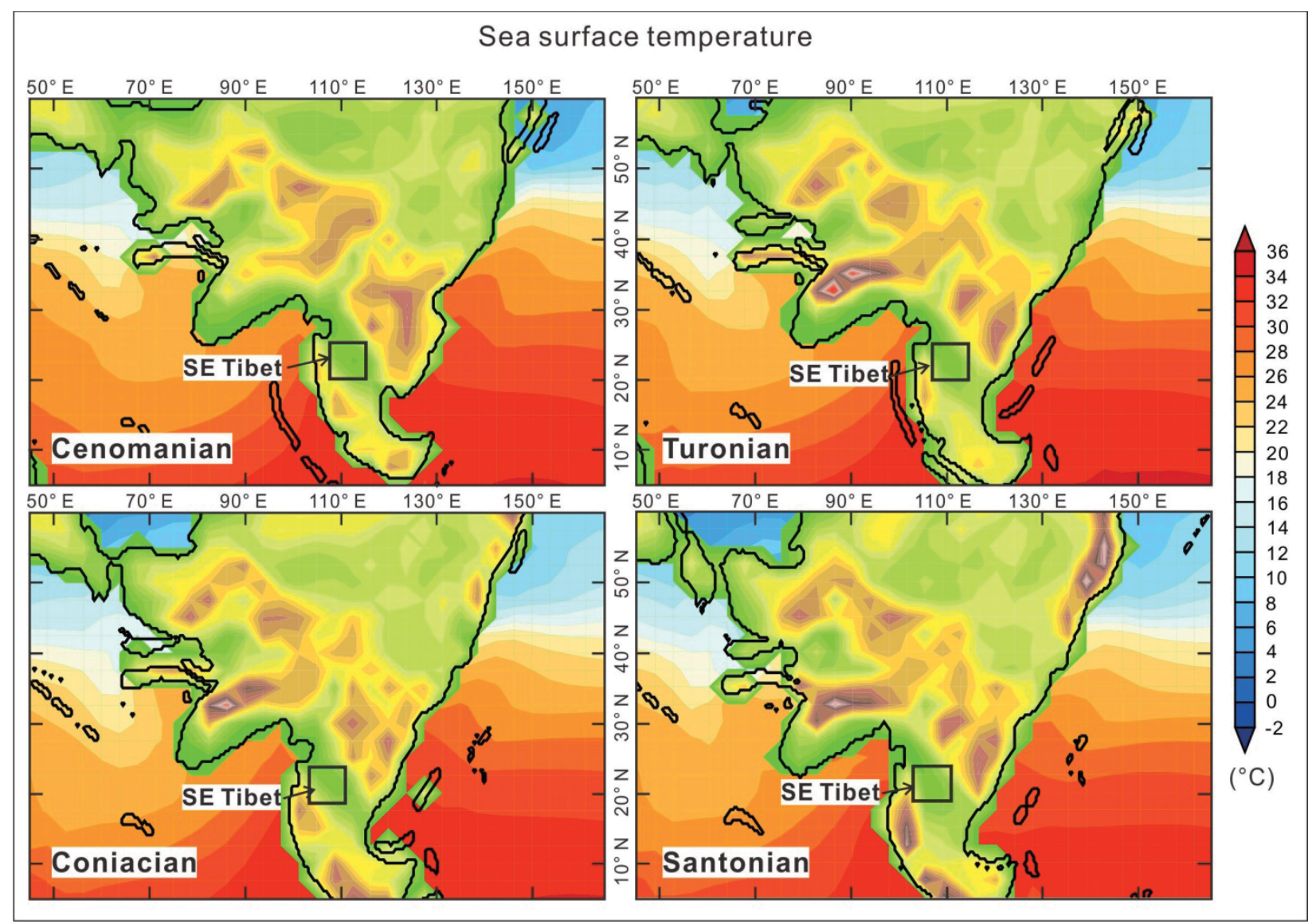

Figure 6. Model-derived summer (i.e., June, July, August, and September) sea surface temperature estimates. Simulations represent time-averaged conditions for four geologic timeslices: Cenomanian, Turonian, Coniacian, and Santonian. 


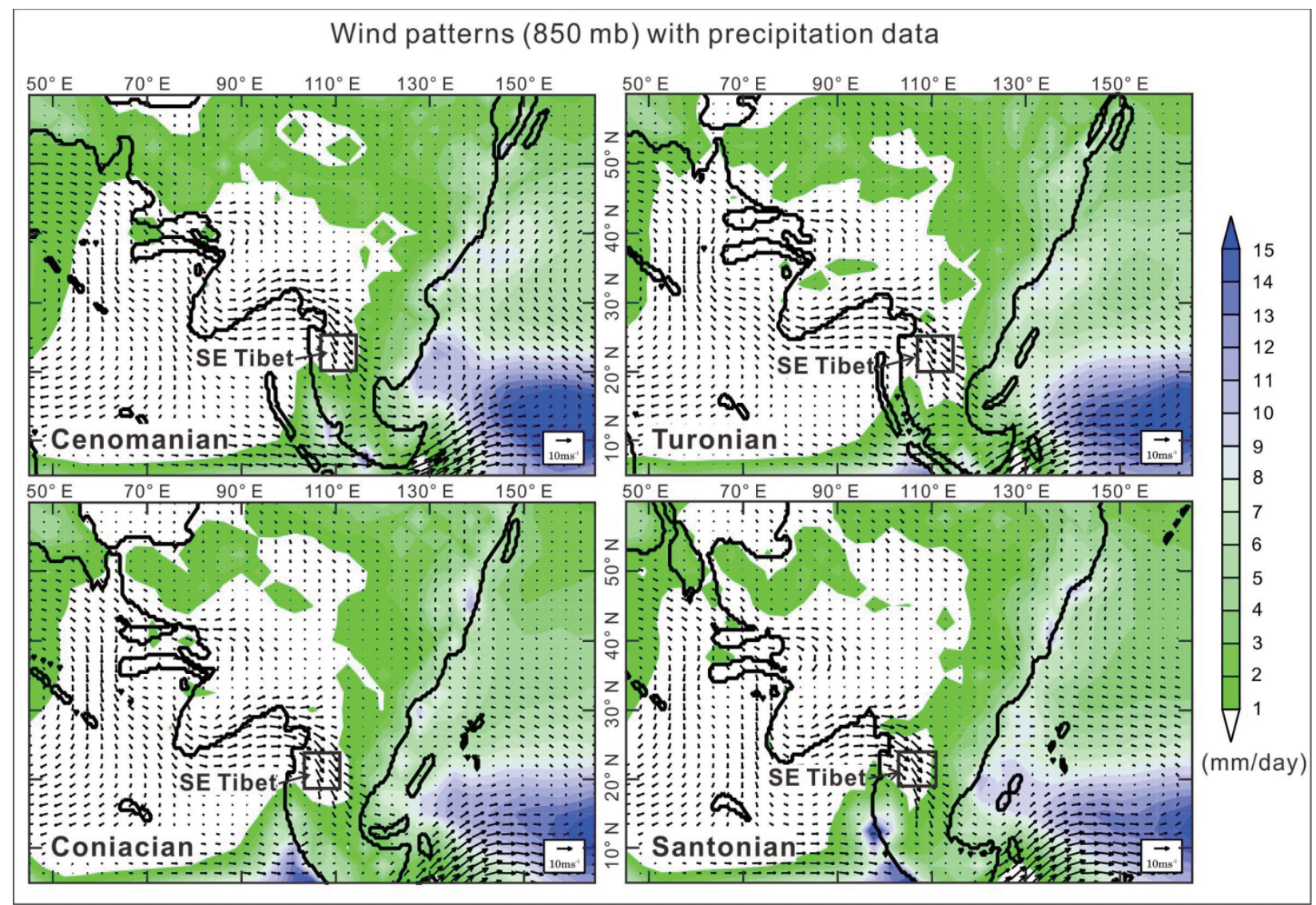

Figure 7. Model-derived summer (i.e., June, July, August, and September) wind pattern (850 $\mathrm{mb}$ ) and precipitation estimates. Simulations represent time-averaged conditions for four geologic time-slices: Cenomanian, Turonian, Coniacian, and Santonian.

\section{Interpretation and Discussion}

\section{Diagenesis consideration}

Isotopic composition of carbonate minerals can be affected by diagenetic processes; therefore, history of diagenesis must be evaluated before meaningful interpretation of any isotopic record. It has been shown that $\Delta_{47}$ values of carbonate can be modified by solid-state C$\mathrm{O}$ bond reordering if a burial temperature exceeds $100{ }^{\circ} \mathrm{C}$ for an extended period of time (Henkes et al., 2014). In our study site, previous study of paleosol carbonates from the lower Nanxing 
Formation (Cenomanian-Turonian in age) reveals that the soil carbonates experienced little diagenetic alterations and preserve their original $\delta^{18} \mathrm{O}$ and $\Delta_{47}$ signals based on combined evidence from burial history, carbonate petrography, and isotopic screening of different carbonate phases (Shang et al., in review). Therefore, there is little reason to believe that soil carbonates from the even shallower upper Nanxing Formation (Coniacian-Santonian in age) with estimated maximum burial depth <500 m (Du et al., 1997) are substantially modified by burial diagenesis. However, shallowly buried carbonate minerals could be altered by diageneitc fluids such as ground waters (e.g., Garzione et al., 2004). Observation of petrographic thin-sections shows that the studied carbonate nodules are dominated by red-brown micritic texture with estimated carbonate cement content less than 3\% (Fig. 3), which suggests that late-stage carbonate recrystallization or replacement was likely insignificant. The inference is further supported by relatively low carbonate $\mathrm{Mg} / \mathrm{Ca}(<0.03)$ and $\mathrm{Sr} / \mathrm{Ca}(<0.001)$ ratios (Table 1) (e.g., Graham et al., 2005).

We noticed that despite carbonate cement only makes up a small percentage of carbonate nodules, the amount of material required for clumped isotope analysis ( $10 \mathrm{mg}$ per sample) makes it possible that minor amount of carbonate cement was also included during sampling. Isotopic screening of micrite and co-existing carbonate cement shows that they have very similar $\delta^{13} \mathrm{C}$ and $\delta^{18} \mathrm{O}$ values, with the differences average $0.14 \%$ (range $=0.01-0.32 \%$ ) and $0.21 \%$ o (range $=0.04-0.41 \%$ ) for $\delta^{13} \mathrm{C}$ and $\delta^{18} \mathrm{O}$, respectively (Table 2 ), whereas isotopic values among different paleosol layers can vary up to $\sim 1.2 \%$ (for $\delta^{18} \mathrm{O}$ ) and $\sim 0.6 \%$ (for $\delta^{13} \mathrm{C}$ ) (Table 2). The similar isotopic patterns have been detected from the underlying Cenomanian-Turonian strata, and are interpreted to reflect early diagenetic origin of carbonate cement formed at near-surface environmental conditions (Shang et al., in review). Here, we suggest that the carbonate cement in 
the overlying Coniacian-Santonian strata are likely characterized by a similar early diagenetic history and therefore primarily reflect near-surface environmental conditions.

\section{Interpretation of surface cooling}

Soil carbonate forming temperatures measured in this study, combined with soil temperature data from Shang et al. (in review) are used to reconstruct the early Late Cretaceous (Cenomanian-Santonian) surface temperature history for SE Tibet (Fig. 4). Two major temperature trends can be observed from the reconstruction: 1) a warming of soil temperature $\sim 10^{\circ} \mathrm{C}$ at the Cenomanian-Turonian transition; and 2) a subsequent cooling of $\sim 6^{\circ} \mathrm{C}$ at the Turonian-Coniacian boundary. The former trend has been attributed to global warming at the Cenomanian-Turonian interval (Shang et al., in review), whereas the cause of the later temperature trend is not clear and it may associated with various factors such as global climate, seasonality of carbonate precipitation, paleo-latitude and/or local topography.

\section{Climate consideration}

Global climate change may account for the observed cooling of soil temperatures during the Coniacian-Santonian time (Fig. 4). Ideally, the best way to evaluate the climatic effect on soil temperatures for our study site is to look at coeval terrestrial temperature records from other regions; however, such data do not exist. Alternatively, marine temperature records (e.g., Bornemann et al., 2008; Forster et al., 2007; Huber et al., 2002; Linnert et al., 2014; Voigt et al., 2004) could be used as indicator for coeval global climate, however, uncertainty rises as local terrestrial climate may or may not respond consistently with the direction and magnitude of global climate change as indicated by marine records (e.g., Snell et al., 2014). Studies have 
shown that land temperatures are often more sensitive to global climate change than marine temperatures (e.g., Lunt et al., 2010; Royer et al., 2012). The amount of temperature amplification on land, however, is not only hard to estimate but varies spatially (locationspecific) (e.g., Kump and Pollard, 2008; Lunt et al., 2010; Renssen et al., 2004; Royer et al., 2012; Snell et al., 2013). To constrain this uncertainty for our study site, we estimated the magnitude of soil temperature response to marine temperature change using the $\Delta_{47}$-soil temperature data from the Cenomanian-Turonian strata in the Markam area (Shang et al., in review). Average Markam soil temperatures increased from $\sim 35{ }^{\circ} \mathrm{C}$ in the Cenomanian to $\sim 44{ }^{\circ} \mathrm{C}$ in the Turonian (Fig. 8B). The estimated soil temperature trend closely mirrors coeval SST (Fig. 8C) and sea bottom temperature (SBT) records inferred from proxy data (Table 4), which both show pronounced warming of marine temperatures $\sim 4-5^{\circ} \mathrm{C}$ during the Cenomanian-Turonian interval (Bornemann et al., 2008; Forster et al., 2007; Huber et al., 2002; Linnert et al., 2014; Voigt et al., 2004). We then compared the amount of temperature change of both soil and marine records in response to the Cenomanian-Turonian global warming (Table 4). The comparison reveals that soil temperatures in our study site are $\sim 2 \mathrm{X}$ more sensitive to both SST and SBT changes (Table 4). The estimated 'soil sensitivity' value was then utilized to predict the amount of soil temperature change in response to the marine temperature variations during the Coniacian-Santonian time in the Markam area (Forster et al., 2007; Bornemann et al., 2008). Marine temperatures indicated by $\mathrm{TEX}_{86}$ proxy (Bornemann et al., 2008; Forster et al., 2007) shows that tropical SSTs stay fairly stable at $\sim 35-36{ }^{\circ} \mathrm{C}$ during the Turonian-Santonian interval (Fig. 8C). The small SST variation would only cause soil temperature change $\sim 1-2{ }^{\circ} \mathrm{C}$ when calculated using the estimated soil temperature 'sensitivity factor' of 2 (Table 4). Obviously, this small soil temperature variation cannot account the $\sim 6^{\circ} \mathrm{C}$ cooling observed in $\Delta_{47}$-soil $\mathrm{T}$ record 
(Fig. 8D). It is worth to note that this estimation assumes that the 'soil sensitivity' value is relatively unchanged throughout the early Late Cretaceous (Cenomanian-Santonian), albeit more coeval terrestrial temperature data from Tibet and adjacent regions are needed to further test this assumption.

Table 4. Comparison of variations of soil and marine temperatures in respond to CenomanianTuronian global warming event

\begin{tabular}{|c|c|c|c|c|}
\hline & $\begin{array}{l}\text { Average soil } \\
\text { temperature }\left({ }^{\circ} \mathrm{C}\right)\end{array}$ & $\begin{array}{l}\text { Average tropical } \\
\text { sea surface temperature } \\
\left({ }^{\circ} \mathrm{C}\right)\end{array}$ & $\begin{array}{l}\text { Average sub-tropical } \\
\text { sea surface } \\
\text { temperature } \\
\left({ }^{\circ} \mathrm{C}\right)\end{array}$ & $\begin{array}{l}\text { Average sub-tropical } \\
\text { sea bottom } \\
\text { temperature }\left({ }^{\circ} \mathrm{C}\right)\end{array}$ \\
\hline $\begin{array}{l}\text { Location } \\
\text { (paleo- } \\
\text { latitude) }\end{array}$ & $\begin{array}{l}\text { Markam, } \\
\text { Southeastern Tibet } \\
\left(\sim 20-25^{\circ} \mathrm{N}\right)\end{array}$ & $\begin{array}{l}\text { Demerara rise, } \\
\text { Atlantic Ocean } \\
\left(\sim 5^{\circ} \mathrm{N}\right)\end{array}$ & $\begin{array}{l}\text { European shelf-sea } \\
\text { basins } \\
\left(26-36^{\circ} \mathrm{N}\right)\end{array}$ & $\begin{array}{l}\text { Black Nose, } \\
\text { North Atlantic } \\
\left(\sim 30^{\circ} \mathrm{N}\right)\end{array}$ \\
\hline Proxy type & $\Delta_{47}($ soil carbonate $)$ & $\mathrm{TEX}_{86}$ (marine organics) & $\delta^{18} \mathrm{O}$ (plankton) & $\delta^{18} \mathrm{O}$ (benthic foram) \\
\hline \multicolumn{5}{|l|}{ Time Interval } \\
\hline Cenomanian & $\sim 35$ & $\sim 31$ & $\sim 18$ & $\sim 14$ \\
\hline Turonian & $\sim 44$ & $\sim 35$ & $\sim 23$ & $\sim 18$ \\
\hline Reference & $\begin{array}{l}\text { Shang et al., } \\
\text { in review }\end{array}$ & $\begin{array}{l}\text { Forster et al., 2007; } \\
\text { Bornemann et al., } 2008\end{array}$ & Voigt et al., 2004 & Huber et al., 2002 \\
\hline $\begin{array}{l}\Delta \mathbf{T}_{\text {cenomanian- }} \\
\text { Turonian }\end{array}$ & $\sim+9$ & $\sim+4$ & $\sim+5$ & $\sim+4$ \\
\hline
\end{tabular}

The inference that global climate change had limited impact on soil temperatures of SE Tibet is also supported by climate simulations showing relatively constant soil temperatures in SE Tibet area (Fig. 5), as well as stable SSTs of east Tethys Ocean throughout the CenomaninaSantonian time interval (Fig. 6). Note that there are two data points in the proxy-derived SST record (Forster et al., 2007) showing that tropical SSTs cooled to $\sim 33{ }^{\circ} \mathrm{C}$ in the latest Santonian (Fig. 8C). However, this latest Santonian cooling event cannot account for the observed Coniacian-Santonian cooling revealed by Markam paleosol record because cooling of soil temperatures preceded cooling of SSTs by $\sim 5 \mathrm{Ma}$ (Fig. 8B, C). 


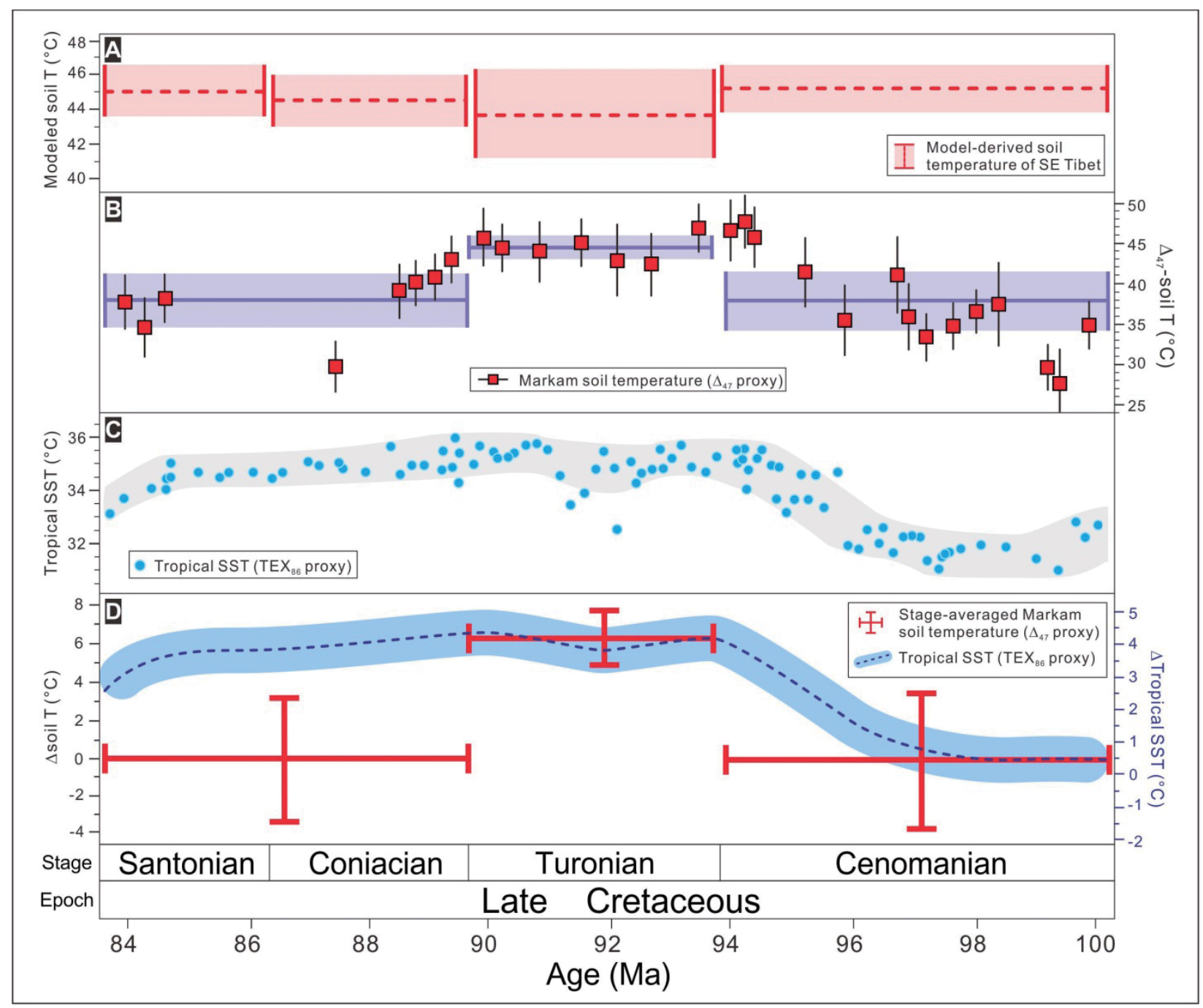

Figure 8. (A) Climate model (HadCM3L) output of average soil temperature (at soil depth between $25 \mathrm{~cm}$ and $65 \mathrm{~cm}$ ) for SE Tibet during the Cenomanian, Turonian, Coniacian and Santonian time slices. Red shading marks $95 \%$ confidence interval (CI) of the modeled mean soil temperature for each modeled geologic stage. (B) Plot of $\Delta_{47}$-soil temperature with stratigraphic height. Filled circles represent samples analyzed in this study, while filled squares represent data compiled from Shang et al., in review. Purple shading represents 95\% CI of the stage-averaged $\Delta_{47}$-T value. (C) The Cenomanian-Santonian tropical sea surface temperatures (SSTs) from organic geochemical analysis (i.e., $\mathrm{TEX}_{86}$ ) of ocean drilling cores (Bornemann et al., 2008; Forster et al., 2007). Blue shading marks the place where $>95 \%$ data points lie. (D) Relative temperature changes of $\Delta_{47}$-Soil T and SST during the Cenomanian-Santonian interval. Note the decreasing soil temperature trend compared with relatively stable SST trend in the Turonian- 
Santonian interval suggests that the observed soil cooling was unlikely resulted from contemporaneous global climate change.

Global climate change could alter seasonality of rainfall and therefore change soil carbonate growth seasons (e.g., Quade et al., 2013). Studies have shown that seasonality of soil

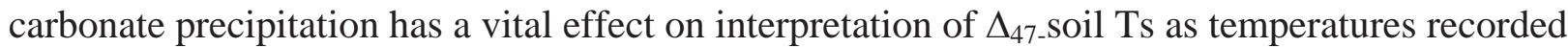
by soil carbonates mainly reflect environmental condition from which they precipitated (e.g., Hough et al., 2014; Peters et al., 2013; Quade et al., 2013). Model-generated precipitation data show that SE Tibet was located in an arid zone with summer precipitation less than $1 \mathrm{~mm} / \mathrm{day}$ throughout the entire Cenomanian-Santonian interval (Fig. 7). The relatively low summer rainfall amount combined with high summer soil temperatures shown by both $\Delta_{47}$ proxy and climate model (Figs. 4, 5) suggest that soil dewatering and subsequent precipitation of soil carbonates mostly happened in summer months (e.g., Breecker et al., 2009; Quade et al., 2013). Therefore, the $\Delta_{47}$-Ts of Markam soil carbonates consistently reflect warm summer soil temperatures during the Cenomanian-Santonian time. Together, multiple lines of evidence discussed above suggest that global climate change cannot account for the observed soil temperature cooling in SE Tibet during the Turonian-Coniacian time (Fig. 8).

Finally, global climate change could also affect $\delta^{18} \mathrm{O}$ values of precipitation and therefore affects $\delta^{18} \mathrm{O}$ values of soil water $\left(\delta^{18} \mathrm{O}_{\text {water }}\right)$. Climatic variables that can influence meteoric $\delta^{18} \mathrm{O}$ compositions include atmospheric circulation pattern, air temperature and vapor source (Rowley, 2007). Simulation of Cretaceous wind patterns over the area of SE Tibet show that circulation patterns were unchanged during the Cenomanian-Santonian interval, with wind blowing constantly from northwest to southeast carrying moistures derived from the east Tethys Ocean 
(Fig. 7). The uniform circulation patterns suggest vapor sources were unlikely changed during the studied time interval. Therefore, the observed decrease of $\delta^{18} \mathrm{O}_{\text {water }}$ values at the TuronianSantonian interval (Fig. 4) is unlikely caused by global climate change, especially when considering the very stable coeval global temperatures inferred from both marine records and climate simulations (Fig. 8A, C).

\section{Tectonic consideration}

Besides global climate change, land surface temperatures can be influenced by tectonic forces expressed as lateral or vertical movement of continental plates. Horizontal plate movement (or continental drift) can change surface temperatures of a region by moving the place from one climatic zone to another. The effect of continental drift on soil temperatures in SE Tibet can be assessed by paleogeographic reconstructions. Paleo-latitude estimate suggests position of SE Tibet was relatively stable at $\sim 20-25^{\circ} \mathrm{N}$ during Late Cretaceous (Lippert et al., 2014); therefore paleo-latitudinal variations should have minimum effects on soil temperatures in our study area. On the other hand, vertical plate movement expressed as surface elevation changes can affect surface temperature and $\delta^{18} \mathrm{O}_{\text {water }}$ values as well (e.g., Rowley and Garzione, 2007). In our study site, average $\Delta_{47}$-soil temperature and $\delta^{18} \mathrm{O}_{\text {water }}$ values decreased $\sim 6{ }^{\circ} \mathrm{C}$ and $\sim 1.0 \%$, respectively during the Turonian-Santonian time interval (Fig. 4), which cannot explained by coeval global climate change or paleogeographic variations as previously discussed. Therefore, it is logical to speculate that the observed systematic decrease of both soil temperature and $\delta^{18} \mathrm{O}_{\text {water }}$ values was due to local elevation change, especially when similar implications that part of Tibet may had been an uplifted region as early as Late Cretaceous have 
been drawn from previous studies (e.g., Kapp et al., 2007).

The inference that our study area may experienced surface uplift during Late Cretaceous is supported by evidence of strontium isotope $\left({ }^{87} \mathrm{Sr} /{ }^{86} \mathrm{Sr}\right)$ ratios and structural features. The strontium isotope results show that soil carbonate ${ }^{87} \mathrm{Sr} /{ }^{86} \mathrm{Sr}$ values gradually increase up-section from 0.7104 in the Cenomanian-Turonian interval to $\sim 0.7112$ in the Coniacain-Santonian

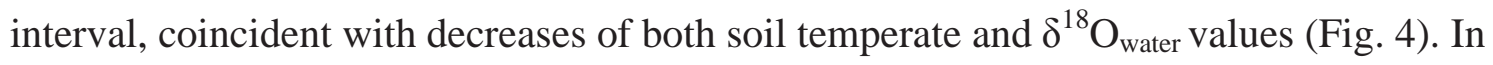
continental setting, ${ }^{87} \mathrm{Sr} /{ }^{86} \mathrm{Sr}$ values of sedimentary rocks are typically related to weathering of rubidium-rich minerals (e.g., K-feldspar, hornblende, micas) in source areas and therefore can be uses as an proxy for weathering intensity (Mulch et al., 2010). Meanwhile, geologic bodies usually bear distinct ${ }^{87} \mathrm{Sr} /{ }^{86} \mathrm{Sr}$ signatures and thus the ${ }^{87} \mathrm{Sr} /{ }^{86} \mathrm{Sr}$ signals preserved in sedimentary rocks can be used as provenance tracers. Detrital zircon age and paleo-current data show that sediments of the Nanxing Formation were sourced primarily from the recycled Upper Triassic strata in Qamdo basin, as well as volcanic rocks of the Jiangda-Weixi arc (JWA) (Shang, 2014). The JWA plutonic rocks have ${ }^{87} \mathrm{Sr} /{ }^{86} \mathrm{Sr}$ ratios range from 7.099 to 0.7113 (Deng et al., 2014; $\mathrm{Zi}$ et al., 2012), whereas Late Triassic crystalline rocks of the Yidun terrane (i.e., a major sediment contributor for Upper Triassic Qamdo strata) (Shang et al., 2014) are characterized by lower ${ }^{87} \mathrm{Sr} /{ }^{86} \mathrm{Sr}$ ratios ranging from 7.051 to 0.7059 (Deng et al., 2014). We suggest that the increase of ${ }^{87} \mathrm{Sr} /{ }^{86} \mathrm{Sr}$ values in Markam paleosols from $\sim 0.7104$ to $\sim 0.7112$ reflects a change of source areas during the Coniacian-Santonian interval. The ${ }^{87} \mathrm{Sr} /{ }^{86} \mathrm{Sr}$ increase was probably associated with enhanced exhumation and weathering of the JWA, implying active tectonics in our study area during the Coniacian-Santonian time. The interpretation is also consistent with increasing sandstone/mudstone ratios up-section (Fig. 4), which suggests enhanced siliciclastic influx during Coniacian-Santonian time. Another piece of evidence for active tectonics in our study site 
during Late Cretaceous is the syntectonic depositions revealed by lateral variations of stratal thickness, or 'growth strata'. The structure is expressed by a gradual decrease of measured bed dip angles, with average dip angles changing from 65 degree in the Cenomanian-Turonian interval to $\sim 40$ degree in the Coniacian-Santonian (Fig. 9). Together, the increase of ${ }^{87} \mathrm{Sr} /{ }^{86} \mathrm{Sr}$ values and syn-tectonic depositions both indicate active tectonisms, and by inference, early Late Cretaceous (Coniacian-Santonian) topographic growth in SE Tibet.

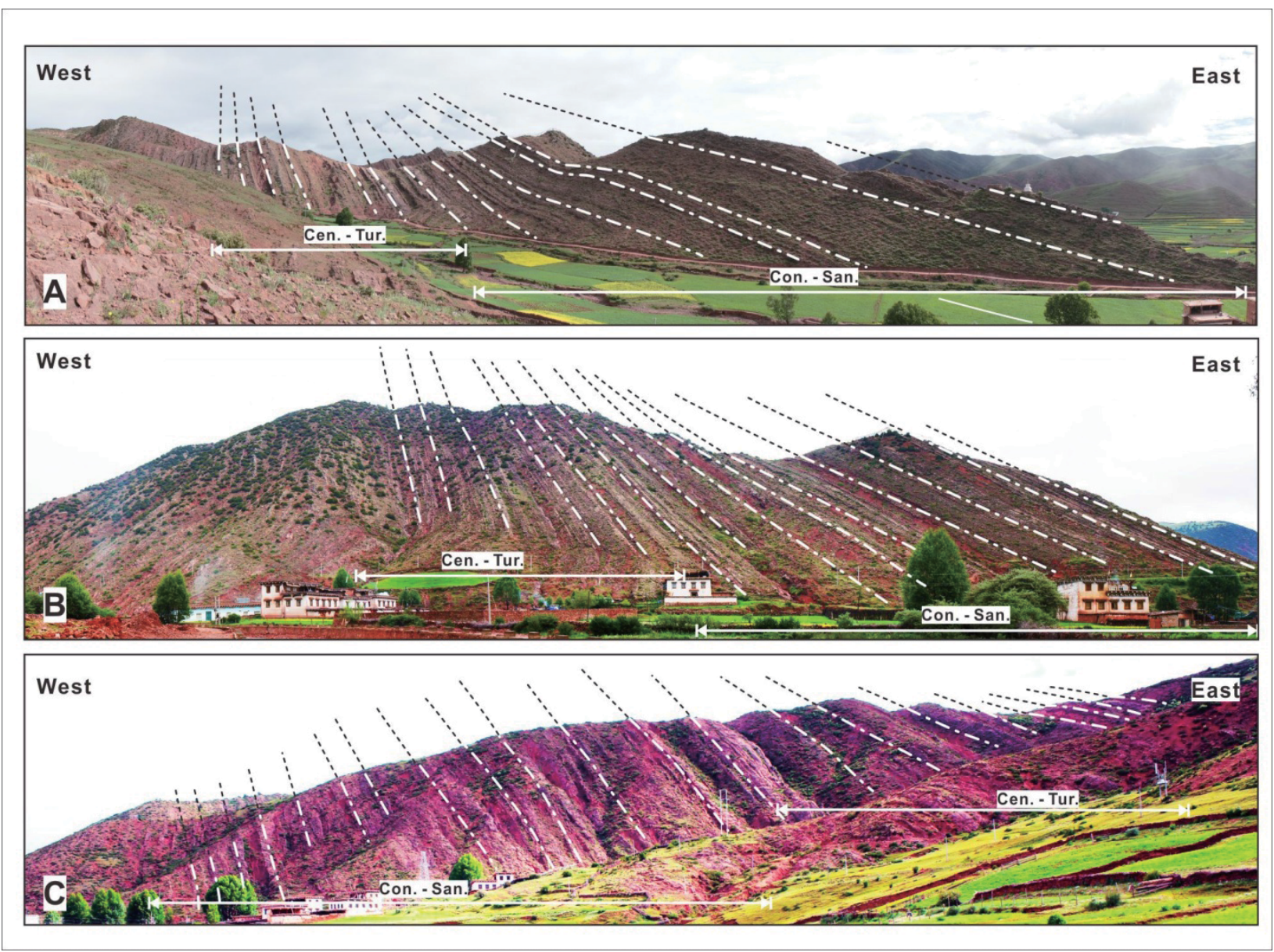

Figure 9. Syntectonic deposition of the Late Cretaceous Naxing Formation indicated by variation of dip angles. Cen.-Tur. - Cenomanian-Turonian strata; Con.-San. - ConiacianSantonian strata. 


\section{Estimation of Late Cretaceous paleo-elevation change for SE Tibet}

During the period of Turonian-Santonian, an average soil temperature drop of $\sim 6{ }^{\circ} \mathrm{C}$ and a $\sim 1.0 \%$ o decrease of average $\delta^{18} \mathrm{O}_{\text {water }}$ values (Fig. 10) were likely caused by local surface uplift. If we assume a present-day global average temperature-elevation gradient of $\sim 6^{\circ} \mathrm{C} / \mathrm{km}$ (Wolfe, 1992), the observed cooling would likely corresponds to a surface elevation gain of $\sim 1 \mathrm{~km}$.

However, taking the extreme equable mid to Late Cretaceous climate condition in to consideration (e.g., Huber et al., 1995), a temperature-elevation gradient of $\sim 6^{\circ} \mathrm{C} / \mathrm{km}$ is probably an overestimation, causing underestimation of paleo-elevation changes. Similarly, the presentday global average oxygen isotopic lapse rate is $\sim 2.8 \% / \mathrm{km}$ (Poage and Chamberlain, 2002), however, model simulations show that warmer climates tend to produce much shallower oxygen isotopic lapse rates (e.g., $\sim 1.2 \% / \mathrm{km}$ when surface temperature $>30{ }^{\circ} \mathrm{C}$ ) (Rowley and Garzione, 2007). During early Late Cretaceous, summer surface temperatures exceeded $30^{\circ} \mathrm{C}$ in our study site (Fig. 4; Table. 3) and the $\sim 1.0 \%$ decrease of $\delta^{18} \mathrm{O}_{\text {water }}$ likely corresponds to a surface elevation gain $\sim 1 \mathrm{~km}$.

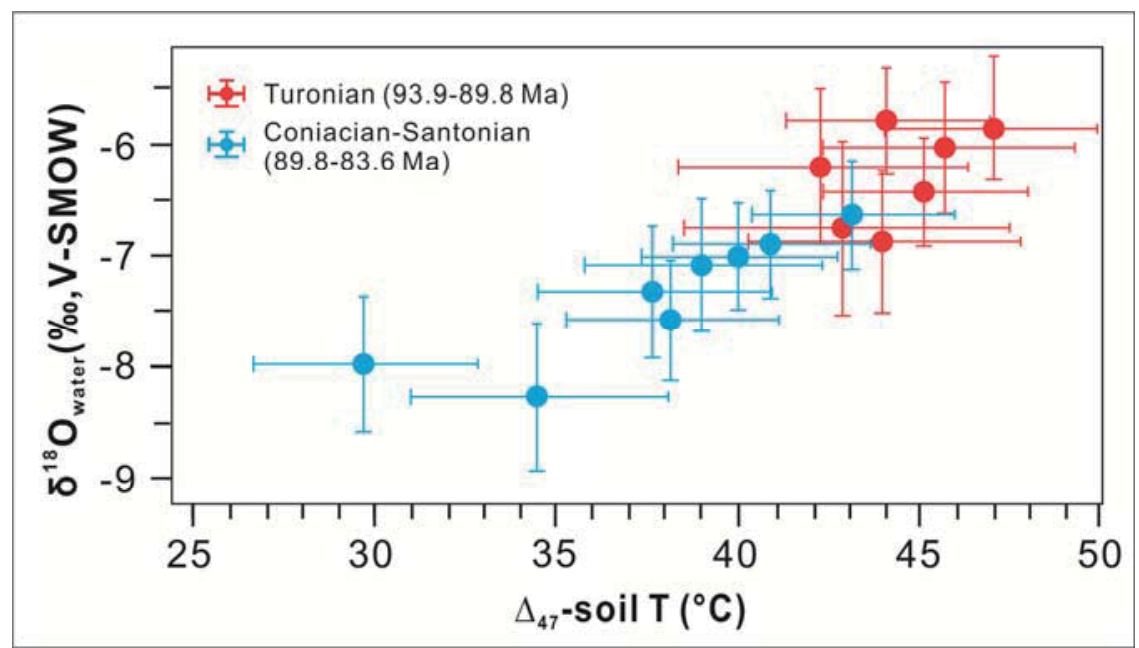

Figure 10. Cross-plot of $\Delta_{47}$-soil temperature and $\delta^{18} \mathrm{O}_{\text {water }}$ values of Markam paleosol carbonates. Red dot represents samples from the Turonian interval (compiled from Shang et al., 
in review) and blue dot marks the data analyzed in this study.

It is worth to note that, however, we are unable to estimate the pre-uplift topography of the study site due to lack of control points from low altitude regions (i.e., coeval terrestrial temperatures close to sea-level). However, abundant conglomerates and localized provenance of detrital zircons (Shang et al., 2014), combined with relatively high ${ }^{87} \mathrm{Sr} /{ }^{86} \mathrm{Sr}$ ratios of paleosol carbonates (>0.70900) (Fig. 4) suggest that the study area must had been uplifted above the sea level before Late Cretaceous. We suggest that a moderate topography $>500 \mathrm{~m}$ was probably established prior to the Cenomanain time. The inference is also consistent with Late Cretaceous paleogeographic reconstructions provided by Geotec Inc. showing SE Tibet was characterized by a moderate topography $\sim 1 \mathrm{~km}$ during the Cenomanian-Santonian time interval (Fig. 2). Together, we suggest that paleo-elevation in our study site was unlikely lower than $1.5 \mathrm{~km}$ by the Santonian stage if we add this 'pre-uplift' topography into our reconstruction.

\section{Tectonic implication}

Our study reveals an episode early Late Cretaceous (Coniacian-Santonian) topographic growth in SE Tibet which broadly supports the Cretaceous 'proto-plateau' hypothesis that part of Tibet may had been uplifted prior to the Indo-Asian collision (e.g., Kapp et al., 2005; 2007; Wang et al., 2008; Sun et al., 2015). However, unlike most studies which infer topographic growth in the Lhasa block (e.g., Wang et al., 2008; Sun et al., 2015). The source to sink relationship indicated by paleocurrent and detrital zircon data suggests that at least the southern Yidun terrane was an elevated topography during early Late Cretaceous, whereas a more extensive regional uplift including the Yidun and eastern Songpan-Ganzi terranes can be inferred 
from rapid rock cooling histories (e.g., Tian et al., 2014), implying high topography may had been spatially more extensive.

Topographic growth of the SE Tibetan Plateau has been attributed to ductile flow of the lower crust from the thickened central Tibetan lithosphere to the margin of SE Tibet during middle to late Miocene time (Clark and Royden, 2000). However, recent study suggests the eastward migration of lower crustal flow was probably not a major cause of uplift of SE Tibet as paleoaltimetry study show the margin of SE Tibet was at its current elevation $\sim 3 \mathrm{~km}$ by late Eocene (Hoke et al., 2014). Our study provides further evidence that a Late Cretaceous 'protoplateau' with elevation $>1.5 \mathrm{~km}$ was probably established in SE Tibet by Santonian ( 83 Ma) and the modern day Tibetan Plateau may inherit some elevation from this paleo-topography.

\section{Conclusion}

By reconstructing soil temperature history, our study reveals an episode of Late Cretaceous (Coniacian-Santonian) topographic growth in SE Tibet. Paleo-elevation in our study site was likely $>1.5 \mathrm{~km}$ by Santonian ( 83 Ma), whereas a more extensive high topography may existed in the Yidun and eastern Songpan-Ganzi terrane as inferred from sediment provenance and thermochronology evidence. Late Cretaceous topographic growth in SE Tibet was probably associated with compressional strain field created by the Lhasa-Qiangtang collision. Our study provides evidence that the modern-day high elevation of SE Tibet is partially inherited from topography developed prior to the India-Asian collision. 


\section{Reference}

Blakey, R.C., 2008. Gondwana paleogeography from assembly to breakup-A 500 my odyssey. Geological Society of America Special Papers, 441: 1-28.

Blisniuk, P.M. and Stern, L.A., 2005. Stable isotope paleoaltimetry: a critical review. American Journal of Science, 305(10): 1033-1074.

Bornemann, A., Norris, R.D., Friedrich, O., Beckmann, B., Schouten, S., Damsté, J.S.S., Vogel, J., Hofmann, P. and Wagner, T., 2008. Isotopic evidence for glaciation during the Cretaceous supergreenhouse. Science, 319(5860): 189-192.

Breecker, D., Sharp, Z. and McFadden, L.D., 2009. Seasonal bias in the formation and stable isotopic composition of pedogenic carbonate in modern soils from central New Mexico, USA. Geological Society of America Bulletin, 121(3-4): 630-640.

Carrapa, B., Huntington, K.W., Clementz, M., Quade, J., Bywater-Reyes, S., Schoenbohm, L.M. and Canavan, R.R., 2014. Uplift of the Central Andes of NW Argentina associated with upper crustal shortening, revealed by multiproxy isotopic analyses. Tectonics, 33(6): 1039-1054.

Clark, M.K. and Royden, L.H., 2000. Topographic ooze: Building the eastern margin of Tibet by lower crustal flow. Geology, 28(8): 703-706.

Clarke, L.J. and Jenkyns, H.C., 1999. New oxygen isotope evidence for long-term Cretaceous climatic change in the Southern Hemisphere. Geology, 27(8): 699-702.

Craig, H. and Gordon, L.I., 1965. Deuterium and oxygen 18 variations in the ocean and the marine atmosphere.

Currie, B.S., Rowley, D.B. and Tabor, N.J., 2005. Middle Miocene paleoaltimetry of southern Tibet: implications for the role of mantle thickening and delamination in the Himalayan orogen. Geology, 33(3): 181-184.

Dansgaard, W., 1964. Stable isotopes in precipitation. Tellus A, 16(4).

Decelles, P.G., Kapp, P., Ding, L. and Gehrels, G., 2007. Late Cretaceous to middle Tertiary basin evolution in the central Tibetan Plateau: Changing environments in response to tectonic partitioning, aridification, and regional elevation gain. Geological Society of America Bulletin, 119(5-6): 654-680.

Deng, B., Liu, S., Li, Z., Cao, J. and Sun, W., 2012. Late cretaceous tectonic change of the eastern margin of the Tibetan Plateau-results from multisystem thermochronology. Journal of the Geological Society of India, 80(2): 241-254.

Deng, J., Wang, Q., Li, G., Li, C. and Wang, C., 2014. Tethys tectonic evolution and its bearing on the distribution of important mineral deposits in the Sanjiang region, SW China. Gondwana Research, 26(2): 419-437.

Dennis, K.J., Affek, H.P., Passey, B.H., Schrag, D.P. and Eiler, J.M., 2011. Defining an absolute reference frame for 'clumped'isotope studies of CO 2. Geochimica et Cosmochimica Acta, 75(22): 7117-7131.

Dewey, J.F. and Burke, K.C., 1973. Tibetan, Variscan, and Precambrian basement reactivation: products of continental collision. The Journal of Geology: 683-692. 
Dewey, J.F., Shackleton, R.M., Chengfa, C. and Yiyin, S., 1988. The tectonic evolution of the Tibetan Plateau. Philosophical Transactions of the Royal Society of London A: Mathematical, Physical and Engineering Sciences, 327(1594): 379-413.

Digital Global, 2015. Source https://www.google.com/maps/@29.6886303, 98.5912691, 2205m $/$ data $=! 3 \mathrm{~m} 1 ! 1 \mathrm{e} 3$

Du, D., Luo, J. and Li, X., 1997. Sedimentary evolution and palaeogeography of the Qamdo Block in Xizang. Lithofacies Palaeogeogr, 17(4): 1-17.

Eiler, J.M., 2007. "Clumped-isotope" geochemistry-The study of naturally-occurring, multiplysubstituted isotopologues. Earth and Planetary Science Letters, 262(3): 309-327.

Eiler, J.M. and Schauble, E., 2004. 18 O 13 C 16 O in Earth's atmosphere. Geochimica et Cosmochimica Acta, 68(23): 4767-4777.

England, P. and Searle, M., 1986. The Cretaceous-Tertiary deformation of the Lhasa block and its implications for crustal thickening in Tibet. Tectonics, 5(1): 1-14.

Fan, M., Hough, B.G. and Passey, B.H., 2014. Middle to late Cenozoic cooling and high topography in the central Rocky Mountains: Constraints from clumped isotope geochemistry. Earth and Planetary Science Letters, 408: 35-47.

Forster, A., Schouten, S., Baas, M. and Damsté, J.S.S., 2007. Mid-Cretaceous (AlbianSantonian) sea surface temperature record of the tropical Atlantic Ocean. Geology, 35(10): 919-922.

Garzanti, E., 2008. Comment on "When and where did India and Asia collide?" by Jonathan C. Aitchison, Jason R. Ali, and Aileen M. Davis. Journal of Geophysical Research: Solid Earth (1978-2012), 113(B4).

Garzione, C.N., Auerbach, D.J., Smith, J.J.-S., Rosario, J.J., Passey, B.H., Jordan, T.E. and Eiler, J.M., 2014. Clumped isotope evidence for diachronous surface cooling of the Altiplano and pulsed surface uplift of the Central Andes. Earth and Planetary Science Letters, 393: 173-181.

Garzione, C.N., Dettman, D.L. and Horton, B.K., 2004. Carbonate oxygen isotope paleoaltimetry: evaluating the effect of diagenesis on paleoelevation estimates for the Tibetan plateau. Palaeogeography, Palaeoclimatology, Palaeoecology, 212(1): 119-140.

Garzione, C.N., Quade, J., DeCelles, P.G. and English, N.B., 2000. Predicting paleoelevation of Tibet and the Himalaya from $\delta 18 \mathrm{O}$ vs. altitude gradients in meteoric water across the Nepal Himalaya. Earth and Planetary Science Letters, 183(1): 215-229.

Ghosh, P., Adkins, J., Affek, H., Balta, B., Guo, W., Schauble, E.A., Schrag, D. and Eiler, J.M., 2006. $13 \mathrm{C}-18 \mathrm{O}$ bonds in carbonate minerals: A new kind of paleothermometer. Geochimica et Cosmochimica Acta, 70(6): 1439-1456.

Gordon, C., Cooper, C., Senior, C.A., Banks, H., Gregory, J.M., Johns, T.C., Mitchell, J.F. and Wood, R.A., 2000. The simulation of SST, sea ice extents and ocean heat transports in a version of the Hadley Centre coupled model without flux adjustments. Climate dynamics, 16(2-3): 147-168.

Gradstein, F.M., Ogg, J.G. and Smith, A.G., 2004. A geologic time scale 2004, 86. Cambridge University Press.

Graham, S.A., Chamberlain, C.P., Yue, Y., Ritts, B.D., Hanson, A.D., Horton, T.W., Waldbauer, J.R., Poage, M.A. and Feng, X., 2005. Stable isotope records of Cenozoic climate and topography, Tibetan plateau and Tarim basin. American Journal of Science, 305(2): 101118. 
Henkes, G.A., Passey, B.H., Grossman, E.L., Shenton, B.J., Pérez-Huerta, A. and Yancey, T.E., 2014. Temperature limits for preservation of primary calcite clumped isotope paleotemperatures. Geochimica et cosmochimica acta, 139: 362-382.

Henkes, G.A., Passey, B.H., Wanamaker, A.D., Grossman, E.L., Ambrose, W.G. and Carroll, M.L., 2013. Carbonate clumped isotope compositions of modern marine mollusk and brachiopod shells. Geochimica et Cosmochimica Acta, 106: 307-325.

Hetzel, R., Dunkl, I., Haider, V., Strobl, M., von Eynatten, H., Ding, L. and Frei, D., 2011. Peneplain formation in southern Tibet predates the India-Asia collision and plateau uplift. Geology, 39(10): 983-986.

Hoke, G.D., Liu-Zeng, J., Hren, M.T., Wissink, G.K. and Garzione, C.N., 2014. Stable isotopes reveal high southeast Tibetan Plateau margin since the Paleogene. Earth and Planetary Science Letters, 394: 270-278.

Hough, B.G., Fan, M. and Passey, B.H., 2014. Calibration of the clumped isotope geothermometer in soil carbonate in Wyoming and Nebraska, USA: Implications for paleoelevation and paleoclimate reconstruction. Earth and Planetary Science Letters, 391: 110-120.

Hren, M.T., Bookhagen, B., Blisniuk, P.M., Booth, A.L. and Chamberlain, C.P., 2009. $\delta 18$ O and $\delta \mathrm{D}$ of streamwaters across the Himalaya and Tibetan Plateau: Implications for moisture sources and paleoelevation reconstructions. Earth and Planetary Science Letters, 288(1): 20-32.

Hren, M.T. and Sheldon, N.D., 2012. Temporal variations in lake water temperature:

Paleoenvironmental implications of lake carbonate $\delta 18 \mathrm{O}$ and temperature records. Earth and Planetary Science Letters, 337: 77-84.

Huang, K., Opdyke, N.D., Li, J. and Peng, X., 1992. Paleomagnetism of Cretaceous rocks from eastern Qiangtang terrane of Tibet. Journal of Geophysical Research: Solid Earth (19782012), 97(B2): 1789-1799.

Huber, B.T., Hodell, D.A. and Hamilton, C.P., 1995. Middle-Late Cretaceous climate of the southern high latitudes: stable isotopic evidence for minimal equator-to-pole thermal gradients. Geological Society of America Bulletin, 107(10): 1164-1191.

Huber, B.T., Norris, R.D. and MacLeod, K.G., 2002. Deep-sea paleotemperature record of extreme warmth during the Cretaceous. Geology, 30(2): 123-126.

Huntington, K.W., Saylor, J., Quade, J. and Hudson, A.M., 2015. High late Miocene-Pliocene elevation of the Zhada Basin, southwestern Tibetan Plateau, from carbonate clumped isotope thermometry. Geological Society of America Bulletin, 127(1-2): 181-199.

Jarvis, I., Lignum, J.S., Gröcke, D.R., Jenkyns, H.C. and Pearce, M.A., 2011. Black shale deposition, atmospheric $\mathrm{CO} 2$ drawdown, and cooling during the Cenomanian-Turonian Oceanic Anoxic Event. Paleoceanography, 26(3).

Kapp, P., DeCelles, P.G., Gehrels, G.E., Heizler, M. and Ding, L., 2007. Geological records of the Lhasa-Qiangtang and Indo-Asian collisions in the Nima area of central Tibet. Geological Society of America Bulletin, 119(7-8): 917-933.

Kapp, P., Murphy, M.A., Yin, A., Harrison, T.M., Ding, L. and Guo, J., 2003. Mesozoic and Cenozoic tectonic evolution of the Shiquanhe area of western Tibet. Tectonics, 22(4).

Kapp, P., Yin, A., Harrison, T.M. and Ding, L., 2005. Cretaceous-Tertiary shortening, basin development, and volcanism in central Tibet. Geological Society of America Bulletin, 117(7-8): 865-878. 
Kent-Corson, M.L., Ritts, B.D., Zhuang, G., Bovet, P.M., Graham, S.A. and Chamberlain, C.P., 2009. Stable isotopic constraints on the tectonic, topographic, and climatic evolution of the northern margin of the Tibetan Plateau. Earth and Planetary Science Letters, 282(1): $158-166$.

Kim, S.-T. and O'Neil, J.R., 1997. Equilibrium and nonequilibrium oxygen isotope effects in synthetic carbonates. Geochimica et Cosmochimica Acta, 61(16): 3461-3475.

Kump, L.R. and Pollard, D., 2008. Amplification of Cretaceous warmth by biological cloud feedbacks. Science, 320(5873): 195-195.

Leier, A., McQuarrie, N., Garzione, C. and Eiler, J., 2013. Stable isotope evidence for multiple pulses of rapid surface uplift in the Central Andes, Bolivia. Earth and Planetary Science Letters, 371: 49-58.

Leier, A.L., Kapp, P., Gehrels, G.E. and DeCelles, P.G., 2007. Detrital zircon geochronology of Carboniferous-Cretaceous strata in the Lhasa terrane, Southern Tibet. Basin Research, 19(3): 361-378.

Linnert, C., Robinson, S.A., Lees, J.A., Bown, P.R., Pérez-Rodríguez, I., Petrizzo, M.R., Falzoni, F., Littler, K., Arz, J.A. and Russell, E.E., 2014. Evidence for global cooling in the Late Cretaceous. Nature communications, 5.

Lippert, P.C., Van Hinsbergen, D.J. and Dupont-Nivet, G., 2014. Early Cretaceous to present latitude of the central proto-Tibetan Plateau: A paleomagnetic synthesis with implications for Cenozoic tectonics, paleogeography, and climate of Asia. Geological Society of America Special Papers, 507: SPE507-01.

Lunt, D.J., Haywood, A.M., Schmidt, G.A., Salzmann, U., Valdes, P.J. and Dowsett, H.J., 2010. Earth system sensitivity inferred from Pliocene modelling and data. Nature Geoscience, 3(1): 60-64.

Lunt, D. J., Farnsworth, A., Loptson, C., Foster, G. L., Markwick, P., O'Brien, C. L., Pancost, R. D., Robinson, S. A., and Wrobel, N., 2015, Palaeogeographic controls on climate and proxy interpretation, Clim. Past Discuss., 11, 5683-5725, doi:10.5194/cpd11-5683-2015, 2015.

Mack, G.H., James, W.C. and Monger, H.C., 1993. Classification of paleosols. Geological Society of America Bulletin, 105(2): 129-136.

Markwick, P., 2007. The palaeogeographic and palaeoclimatic significance of climate proxies for data-model comparisons. Deep-time perspectives on climate change: marrying the signal from computer models and biological proxies: 251-312.

Meyer, H.W., 1992. Lapse rates and other variables applied to estimating paleoaltitudes from fossil floras. Palaeogeography, Palaeoclimatology, Palaeoecology, 99(1): 71-99.

Meyer, H.W., 2007. A review of paleotemperature-lapse rate methods for estimating paleoelevation from fossil floras. Reviews in Mineralogy and Geochemistry, 66(1): 155171.

Mulch, A., Uba, C.E., Strecker, M.R., Schoenberg, R. and Chamberlain, C.P., 2010. Late Miocene climate variability and surface elevation in the central Andes. Earth and Planetary Science Letters, 290(1): 173-182.

Murphy, M., Yin, A., Harrison, T., Dürr, S., Chen, Z., Ryerson, F., Kidd, W., Wang, X. and Zhou, X., 1997. Did the Indo-Asian collision alone create the Tibetan plateau? Geology, 25(8): 719-722. 
NGDR, 1999 National Geophysical Data Center, 1999. Global Land One-kilometer Base Elevation (GLOBE) v.1. Hastings, D. and P.K. Dunbar. National Geophysical Data Center, NOAA. doi:10.7289/V52R3PMS [access date: 2015-03-16].

Norris, R.D., Bice, K.L., Magno, E.A. and Wilson, P.A., 2002. Jiggling the tropical thermostat in the Cretaceous hothouse. Geology, 30(4): 299-302.

Otofuji, Y.-i., Inoue, Y., Funahara, S., Murata, F. and Zheng, X., 1990. Palaeomagnetic study of eastern Tibet-deformation of the Three Rivers region. Geophysical Journal International, 103(1): 85-94.

Pan, G.-t., Ding, J., Yao, D.-s. and Wang, L.-q., 2004. Geological map of the Qinghai-Xizang (Tibet) Plateau and adjacent areas. Chengdu Cartographic Oublishing House.

Passey, B.H., Levin, N.E., Cerling, T.E., Brown, F.H. and Eiler, J.M., 2010. High-temperature environments of human evolution in East Africa based on bond ordering in paleosol carbonates. Proceedings of the National Academy of Sciences, 107(25): 11245-11249.

Peters, N.A., Huntington, K.W. and Hoke, G.D., 2013. Hot or not? Impact of seasonally variable soil carbonate formation on paleotemperature and O-isotope records from clumped isotope thermometry. Earth and Planetary Science Letters, 361: 208-218.

Poage, M. and Chamberlain, C., 2002. Stable isotopic evidence for a pre-Middle Miocene rain shadow in the western Basin and Range: Implications for the paleotopography of the Sierra Nevada. Tectonics, 21(4): 16-1-16-10.

Poage, M.A. and Chamberlain, C.P., 2001. Empirical relationships between elevation and the stable isotope composition of precipitation and surface waters: considerations for studies of paleoelevation change. American Journal of Science, 301(1): 1-15.

Polissar, P.J., Freeman, K.H., Rowley, D.B., McInerney, F.A. and Currie, B.S., 2009. Paleoaltimetry of the Tibetan Plateau from D/H ratios of lipid biomarkers. Earth and Planetary Science Letters, 287(1): 64-76.

Powell, C.M. and Conaghan, P., 1973. Plate tectonics and the Himalayas. Earth and Planetary Science Letters, 20(1): 1-12.

Quade, J., Breecker, D.O., Daëron, M. and Eiler, J., 2011. The paleoaltimetry of Tibet: An isotopic perspective. American Journal of Science, 311(2): 77-115.

Quade, J., Eiler, J., Daeron, M. and Achyuthan, H., 2013. The clumped isotope geothermometer in soil and paleosol carbonate. Geochimica et Cosmochimica Acta, 105: 92-107.

Quade, J., Garzione, C. and Eiler, J., 2007. Paleoelevation reconstruction using pedogenic carbonates. Reviews in Mineralogy and Geochemistry, 66(1): 53-87.

Ray, S., Gault, H. and Dodd, C.G., 1957. The separation of clay minerals from carbonate rocks. Am. Mineral, 42: 681-686.

Reid, A.J., Wilson, C.J. and Liu, S., 2005. Structural evidence for the Permo-Triassic tectonic evolution of the Yidun Arc, eastern Tibetan Plateau. Journal of Structural Geology, 27(1): 119-137.

Renssen, H., Beets, C., Fichefet, T., Goosse, H. and Kroon, D., 2004. Modeling the climate response to a massive methane release from gas hydrates. Paleoceanography, 19(2).

Rohrmann, A., Kapp, P., Carrapa, B., Reiners, P.W., Guynn, J., Ding, L. and Heizler, M., 2012. Thermochronologic evidence for plateau formation in central Tibet by $45 \mathrm{Ma}$. Geology, 40(2): 187-190.

Rohrmann, A., Strecker, M.R., Bookhagen, B., Mulch, A., Sachse, D., Pingel, H., Alonso, R.N., Schildgen, T.F. and Montero, C., 2014. Can stable isotopes ride out the storms? The role 
of convection for water isotopes in models, records, and paleoaltimetry studies in the central Andes. Earth and Planetary Science Letters, 407: 187-195.

Rowley, D.B., 1996. Age of initiation of collision between India and Asia: A review of stratigraphic data. Earth and Planetary Science Letters, 145(1): 1-13.

Rowley, D.B., 2007. Stable isotope-based paleoaltimetry: Theory and validation. Reviews in Mineralogy and Geochemistry, 66(1): 23-52.

Rowley, D.B. and Garzione, C.N., 2007. Stable isotope-based paleoaltimetry. Annu. Rev. Earth Planet. Sci., 35: 463-508.

Royer, D., Pagani, M. and Beerling, D., 2012. Geobiological constraints on Earth system sensitivity to CO2 during the Cretaceous and Cenozoic. Geobiology, 10(4): 298-310.

Saylor, J., Quade, J., Dettman, D., DeCelles, P., Kapp, P. and Ding, L., 2009. The late Miocene through present paleoelevation history of southwestern Tibet. American Journal of Science, 309(1): 1-42.

SHANG, F., 2014. DETRITAL ZIRCON GEOCHRONOLOGY FROM THE MESOZOIC QAMDO (CHANGDU) BASIN, SOUTHEASTERN TIBET: IMPLICATIONS FOR THE PALEO-AND MESO-TETHYS EVOLUTION, 2014 GSA Annual Meeting in Vancouver, British Columbia.

Snell, K.E., Koch, P.L., Druschke, P., Foreman, B.Z. and Eiler, J.M., 2014. High elevation of the 'Nevadaplano' during the Late Cretaceous. Earth and Planetary Science Letters, 386: 5263.

Snell, K.E., Thrasher, B.L., Eiler, J.M., Koch, P.L., Sloan, L.C. and Tabor, N.J., 2013. Hot summers in the Bighorn Basin during the early Paleogene. Geology, 41(1): 55-58.

Studnicki-Gizbert, C., Burchfiel, B., Li, Z. and Chen, Z., 2008. Early Tertiary Gonjo basin, eastern Tibet: Sedimentary and structural record of the early history of India-Asia collision. Geosphere, 4(4): 713-735.

Sun, G., Hu, X., Sinclair, H.D., BouDagher-Fadel, M.K. and Wang, J., 2015. Late Cretaceous evolution of the Coqen Basin (Lhasa terrane) and implications for early topographic growth on the Tibetan Plateau. Geological Society of America Bulletin: B31137. 1.

Tian, Y., Kohn, B.P., Hu, S. and Gleadow, A.J., 2014. Postorogenic rigid behavior of the eastern Songpan-Ganze terrane: Insights from low-temperature thermochronology and implications for intracontinental deformation in central Asia. Geochemistry, Geophysics, Geosystems, 15(2): 453-474.

Tripati, A.K., Eagle, R.A., Thiagarajan, N., Gagnon, A.C., Bauch, H., Halloran, P.R. and Eiler, J.M., 2010. $13 \mathrm{C}-18 \mathrm{O}$ isotope signatures and 'clumped isotope'thermometry in foraminifera and coccoliths. Geochimica et Cosmochimica Acta, 74(20): 5697-5717.

Tripati, A.K., Hill, P.S., Eagle, R.A., Mosenfelder, J.L., Tang, J., Schauble, E.A., Eiler, J.M., Zeebe, R.E., Uchikawa, J. and Coplen, T.B., 2015. Beyond temperature: Clumped isotope signatures in dissolved inorganic carbon species and the influence of solution chemistry on carbonate mineral composition. Geochimica et Cosmochimica Acta, 166: 344-371.

Voigt, S., Gale, A.S. and Flögel, S., 2004. Midlatitude shelf seas in the Cenomanian-Turonian greenhouse world: Temperature evolution and North Atlantic circulation. Paleoceanography, 19(4).

Volkmer, J.E., Kapp, P., Guynn, J.H. and Lai, Q., 2007. Cretaceous-Tertiary structural evolution of the north central Lhasa terrane, Tibet. Tectonics, 26(6). 
Wang, C., Zhao, X., Liu, Z., Lippert, P.C., Graham, S.A., Coe, R.S., Yi, H., Zhu, L., Liu, S. and Li, Y., 2008. Constraints on the early uplift history of the Tibetan Plateau. Proceedings of the National Academy of Sciences, 105(13): 4987-4992.

Wang, X.-S., Hu, R.-Z., Bi, X.-W., Leng, C.-B., Pan, L.-C., Zhu, J.-J. and Chen, Y.-W., 2014. Petrogenesis of Late Cretaceous I-type granites in the southern Yidun Terrane: New constraints on the Late Mesozoic tectonic evolution of the eastern Tibetan Plateau. Lithos, 208: 202-219.

Wilson, C.J. and Fowler, A.P., 2011. Denudational response to surface uplift in east Tibet: Evidence from apatite fission-track thermochronology. Geological Society of America Bulletin, 123(9-10): 1966-1987.

Wolfe, J.A., 1992. An analysis of present-day terrestrial lapse rates in the western conterminous United States and their significance to paleoaltitudinal estimates, US Geological Survey, US, GPO; Books and Open-File Reports Section [distributor].

Zhang, K.-J., Zhang, Y.-X., Tang, X.-C. and Xia, B., 2012. Late Mesozoic tectonic evolution and growth of the Tibetan plateau prior to the Indo-Asian collision. Earth-Science Reviews, 114(3): 236-249.

Zi, J.W., Cawood, P.A., Fan, W.M., Wang, Y.J. and Tohver, E., 2012. Contrasting rift and subduction-related plagiogranites in the Jinshajiang ophiolitic mélange, southwest China, and implications for the Paleo-Tethys. Tectonics, 31(2). 